André Marcon Trotta

\title{
ESTUDO EXPERIMENTAL DE UMA LIGAÇÃO VIGA-PILAR EM CONCRETO PRÉ-MOLDADO UTILIZANDO PERFIS METÁLICOS E SOLDA
}

Dissertação apresentada à Escola de Engenharia de São Carlos da Universidade de São Paulo como parte dos requisitos para obtenção do título de Mestre em Engenharia de Estruturas.

Orientador: Prof. Titular Dr. Mounir Khalil El Debs

\section{Versão Corrigida}

A versão original encontra-se na Escola de Engenharia de São Carlos

\author{
São Carlos
}


AUTORIZO A REPRODUÇÃO E DIVULGAÇ̃̃O TOTAL OU PARCIAL DESTE TRABALHO, POR QUALQUER MEIO CONVENCIONAL OU ELETRÔNICO, PARA FINS DE ESTUDO E PESQUISA, DESDE QUE CITADA A FONTE.

Ficha catalográfica preparada pela Seção de Tratamento da Informação do Serviço de Biblioteca - EESC/USP

Trotta, André Marcon

T858e Estudo experimental de uma ligação viga-pilar em concreto pré-moldado utilizando perfis metálicos e solda. / André Marcon Trotta ; orientador Mounir Khalil El Debs. São Carlos, 2012 .

Dissertação (Mestrado - Programa de Pós-Graduação em Engenharia de Estruturas)-- Escola de Engenharia de São Carlos da Universidade de São Paulo, 2012.

1. Concreto pré-moldado. 2. Ligação viga-pilar. 3. Ligação resistente a momento fletor. 4. Ligação mista em aço e concreto. I. Título. 


\section{FOLHA DE IULGAMENTO}

\section{Candidata: Engenheiro ANDRÉ MARCON TROTTA.}

Título da dissertação: "Estudo experimental de uma ligação viga-pilar em concreto prémoldado utilizando perfis metálicos e solda".

Data da defesa: 03/09/2012

\section{Comissão Julgadora:}

Prof. Titular Mounir Khalil El Debs (Orientador)

(Escola de Engenharia de São Carlos/EESC)

Prof. Associado Maximiliano Malite

(Escola de Engenharia de São Carlos/EESC)

Prof. Dr. Pedro Wellington Gonçalves do Nascimento Teixeira (Escola Politécnica/USP)
Resultado:
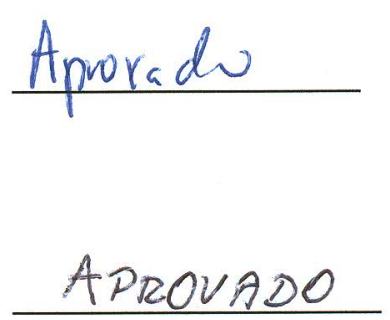

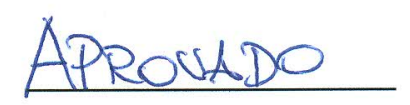

Coordenador do Programa de Pós-Graduação em Engenharia Civil (Engenharia de Estruturas):

Profa. Associada Ana Lucia Homce de Cresce El Debs

Presidente da Comissão de Pós-Graduação:

Prof. Titular Denis Vinicius Coury 



\section{AGRADECIMENTOS}

Ao professor Mounir Khalil El Debs pela orientação, dedicação, paciência e amizade.

Aos meus pais João e Vanda e minha irmã Renata pela educação dada e apoio incondicional.

A toda a minha família e minha namorada Marina que me ajudou incentivando e torcendo para que tudo desse certo.

Aos amigos que fiz no Departamento de Engenharia de Estruturas da EESC-USP em especial a Rafael Marques Lins.

A Luiz Álvaro de Oliveira Júnior pela ajuda prestada na realização deste trabalho.

Aos professores do Departamento de Engenharia de Estruturas da EESC-USP.

Aos funcionários do Departamento de Engenharia de Estruturas da EESC-USP.

A toda a equipe do laboratório de estruturas da EESC-USP pela ajuda na construção do modelo estudado e na realização do ensaio. 



\section{RESUMO}

TROTTA, A. M. (2012). Estudo experimental de uma ligação viga-pilar em concreto prémoldado utilizando perfis metálicos e solda. Dissertação (Mestrado) - Escola de Engenharia de São Carlos, Universidade de São Paulo, São Carlos. 2012.

Nesta pesquisa estudou-se o comportamento de uma ligação viga-pilar em concreto prémoldado utilizando perfis metálicos embutidos nos elementos estruturais. O modelo da ligação estudada permite a transmissão de momentos fletores positivo e negativo. Para a continuidade de momento fletor negativo, utilizam-se um consolo metálico com seção "U" embutido no pilar e dentes metálicos com seção tubular retangular embutidos nas vigas, soldados. Para a continuidade de momento positivo, utilizam-se cantoneiras metálicas embutidas no pilar que são soldadas à armadura positiva da viga. $\mathrm{O}$ estudo consistiu em análise experimental de um modelo cruciforme em duas etapas. Na primeira etapa o modelo foi solicitado a carregamentos cíclicos reversíveis por meio de um atuador servo hidráulico acoplado sobre o topo do pilar. Na segunda etapa, o modelo foi solicitado a carregamento estático monotônico por meio de macacos hidráulicos dispostos sob o pilar para causar a ruptura com momento negativo. O modelo apresentou uma considerável facilidade de montagem, já que na fase transitória a ligação é articulada e o consolo do pilar em perfil "U" permite a estabilidade lateral da viga. O consolo metálico embutido no pilar escoou muito antes de atingir a capacidade resistente dos outros componentes da ligação, pois na seção da ligação junto à face do pilar, apenas o consolo resiste à flexão.

Palavras chave: concreto pré-moldado, ligação viga-pilar, ligação resistente a momento fletor, ligação mista em aço e concreto. 


\section{ABSTRACT}

TROTTA, A. M. (2012). Experimental study of a precast concrete beam-column connection using welded steel shapes. M.Sc. Dissertation - Escola de Engenharia de São Carlos, Universidade de São Paulo, São Carlos. 2012.

In this research the behavior of a beam-column connection in precast concrete system using welded steel shapes built-in structural elements was studied. The model of the studied connection allows transmission of positive and negative moments. For the continuity of negative moment, is used a steel "U" shaped corbel inserted in the column welded with tubular section steel hangers inserted in each beam. For the continuity of positive moment, use is made of metal embedded in abutment ledges that are welded to the positive reinforcement of the beam. The study consisted on experimental analysis of a cross-shaped specimen in two steps. In the first step was applied to the specimen a cyclic load using hydraulic actuator coupled to the column head. In the second step was applied in the specimen a static load using hydraulic jack positioned under the column to cause rupture with negative moment. The connection model showed a considerably easy assembly, as in the transitional phase the connection is articulated and the steel " $U$ " shaped corbel of the column allows the lateral stability of the beam. The rupture occurred by yielding of the steel " $U$ " shaped corbel in the section near the column. The steel corbel inserted in the column yielded before reaches the resistant capacity of other components of the connection, because of the section in the connection close of the column, only steel corbel resists the negative moment.

Key-words: precast concrete, beam-column connection, moment resistant connection, hybrid steel-concrete connection. 


\section{LISTA DE FIGURAS}

Figura 1.1 - Esboço do modelo de ligação estudado por OLIVEIRA JUNIOR (2009): (a) Esquema geral e (b) Componentes da ligação

Figura 1.2 - Esquema de ligação estudada

Figura 2.1: Detalhe do modelo de bielas e tirantes aplicado no consolo do pilar e no dente da viga.

Figura 2.2 - Tipos de consolo metálico embutido no pilar (2004)

Figura 2.3 - Hipóteses para verificação do consolo metálico assimétrico embutido no pilar (2004)

Figura 2.4 - Esquema “CazalyHanger” e hipóteses de distribuição das tensões e das forças (2004)

Figura 2.5 - Modelo de ligação de OLIVEIRA JÚNIOR (2009): a) fase de

montagem, b) fase definitiva antes da concretagem da ligação

Figura 2.6 - Modelo apresentado pelo CEB-FIP (2008): a) elementos metálicos

soldados, b) armadura negativa atravessando o pilar.

Figura 2.7 - Componentes da ligação e forças atuantes no modelo do CEB-FIP (2008).

Figura 2.8 - Detalhes dos modelos de ligações resistentes ao momento fletor estudados por DOLAN; STANTON e ANDERSON (1987).

Figura 2.9 - Detalhe do modelo de ligação: a) vista lateral da ligação, b) vista superior da ligação; c) detalhe do dispositivo metálico (1991).

Figura 2.10 - Recomendações: a) dispositivo metálico com mísulas, b) estribos e armadura de costura (1991).

Figura 2.11 - Detalhe do modelo monolítico, ERTAS; OZDEN e OZTURAN (2006)

Figura 2.12 - Detalhe do modelo com a ligação no pilar moldada no local, ERTAS; OZDEN e OZTURAN (2006).

Figura 2.13 - Detalhe do modelo com a ligação na viga moldada no local, ERTAS;

OZDEN e OZTURAN (2006). 
Figura 2.14 - Detalhe do modelo com a ligação mista usando chapas metálicas soldadas e consolo de concreto no pilar, ERTAS; OZDEN e OZTURAN (2006)......

Figura 2.15 - Detalhe do modelo com a ligação protendida, ERTAS; OZDEN e OZTURAN (2006)

Figura 2.16 - Esquema de carregamento lateral dos modelos de ERTAS; OZDEN e OZTURAN (2006)

Figura 2.17 - Resultados dos ensaios de ERTAS; OZDEN e OZTURAN (2006): a) modelo monolítico, b) modelo da ligação no pilar moldada no local, c) modelo da ligação na viga moldada no local, d) modelo da ligação mista, e) modelo da ligação protendida, f) modelo da ligação protendida modificada.

Figura 2.18 - Modelo de ligação viga pilar estudado por KULKARNI; LI e YIP (2008).

Figura 2.19 - Resultados dos ensaios de KULKARNI; LI e YIP (2008): a) modelo monolítico, b) modelo da Figura 2.18.

Figura 3.1 - Dimensões do modelo ensaiado.

Figura 3.2 - Componentes da ligação.

Figura 3.3 - Sequência de montagem da ligação.

Figura 3.4 - Detalhamento das armaduras das vigas e dos elementos ligação (corte AA).

Figura 3.5 - Detalhamento das armaduras das vigas e dos elementos ligação (corte $\mathrm{BB}$ e $\mathrm{CC})$

Figura 3.6 - a) Detalhe da armadura do pilar; b) Detalhe do pilar da região de ligação.

Figura 3.7 - Detalhamento das armaduras do pilar e dos elementos da ligação..........

Figura 3.8 - Detalhe dos elementos metálicos embutidos nas vigas e no pilar...........

Figura 3.9 - Detalhe da armadura da capa da laje.

Figura 3.10 - Dimensões dos tacos utilizados para moldar as chaves de cisalhamento. 
Figura 3.11 - Peça de fechamento lateral da forma do pilar com os recortes para a passagem dos perfis metálicos e os moldes das chaves de cisalhamento.

Figura 3.12 - Detalhamento das formas dos elementos pré-moldados

Figura 3.13 - Solda da armadura negativa no dente metálico

Figura 3.14 - Detalhe da solda entre a barra de armadura e a chapa metálica

Figura 3.15 - Armadura da viga pré-moldada

Figura 3.16 - Montagem da armadura do pilar pré-moldado

Figura 3.17 - Encaixe da armadura do pilar na forma.

Figura 3.18 - Encaixe da armadura das vigas nas formas.

Figura 3.19 - Concretagem das vigas e pilar pré-moldado.

Figura 3.20 - Sequência de montagem do modelo até a execução da solda.

Figura 3.21 - Concretagem das ligações

Figura 3.22 - Etapa de execução da laje

Figura 3.23 - Ensaios de caracterização dos concretos.

Figura 3.24- Ensaios de caracterização dos concretos.

Figura 3.25 - Dimensões dos corpos de prova dos perfis metálicos (medidas em $\mathrm{mm})$.

Figura 3.26 - Corpos de prova após ensaio de caracterização do aço dos perfis metálicos.

Figura 3.27 - Extensômetros das armaduras longitudinais e do perfil metálico embutidos na viga.

Figura 3.28 - Extensômetros das armaduras transversais.

Figura 3.29 - Extensômetros dos perfis metálicos embutidos no pilar..

Figura 3.30 - Ilustração da instrumentação externa.

Figura 3.31 - Vista geral e detalhamento da instrumentação externa

Figura 3.32 - Esquema de ensaio da primeira etapa 
Figura 3.34 - Vista geral do esquema de ensaio

Figura 3.35 - Dispositivos para aplicação de força e reação.

Figura 3.36 - Sentido das forças aplicadas na primeira etapa.

Figura 4.1 - Média das medidas de deformação no consolo metálico do pilar (extensômetros 25, 26, 27 e 28).

Figura 4.2 - Envoltória da curva força aplicada no pilar por deformação do consolo metálico.

Figura 4.3 - Curva força aplicada-deformação do dente metálico na seção próxima à viga pré-moldada (extensômetros 11 e 23).

Figura 4.4 - Curva força aplicada-deformação do dente metálico na seção próxima ao pilar (extensômetros 12 e 24).

Figura 4.5 - Região de escoamento do consolo metálico.

Figura 4.6 - Curva força aplicada-deformação das armaduras negativas (extensômetros 1, 2, 14 e 15)

Figura 4.7 - Curva força aplicada-deformação das cantoneiras embutidas no pilar (extensômetros 30, 31, 32, 33, 34, 35 e 36).

Figura 4.8 - Curva força aplicada-deformação das armaduras positivas na ligação (extensômetros 9, 10, 21 e 22).

Figura 4.9 - Curva força aplicada-deformação das armaduras positivas na viga prémoldada (extensômetros 3, 4, 15 e 16).

Figura 4.10 - Fissuração da capa da laje durante o ensaio da primeira etapa.

Figura 4.11 - Fissuração da superfície inferior da laje durante o ensaio da primeira etapa.

Figura 4.12 - Fissuração das ligações durante a primeira etapa do ensaio. 82

Figura 4.13 - Deslocamento relativo do pilar e os apoios

Figura 4.14 - Curva força no pilar-deformação do consolo metálico quando aplicado momento negativo (extensômetros 25, 26, 27 e 28).....

Figura 4.15 - Curva força no pilar-deformação do consolo - média das 
deformações medidas pelos extensômetros $25,26,27$ e 28 .

Figura 4.16 - Curva força no pilar-deformação do dente metálico na seção próxima ao pilar - média das deformações medidas pelos extensômetros 12 e 24

Figura 4.17 - Curva força no pilar-deformação do dente metálico na seção próxima a viga - média das deformações medidas pelos extensômetros 11 e 23 .

Figura 4.18 - Curva força no pilar-deformação das armaduras negativas das vigas (extensômetros 1, 2, 14 e 15)

Figura 4.19 - Curva força no pilar-deformação das armaduras negativas das vigas média dos valores de deformação das duas vigas

Figura 4.20 - Fissuras devidas ao cisalhamento na interface dos painéis alveolares da laje com a capa de concreto.

Figura 4.21 - Fissuras devido ao momento negativo na capa da laje.

Figura 4.22 - Detalhe das fissuras na capa da laje.

Figura 4.23 - Mudança de direção das fissuras próximas ao apoio

Figura 4.24 - Detalhe das fissuras verticais na laje nos dois apoios

Figura 4.25 - Vista geral da fissuração ocorrida nas vigas do modelo.

Figura 4.26 - Detalhe da fissuração nas vigas pré-moldadas.

Figura 4.27 - Modelo de cálculo para o consolo.

Figura 4.28 - Detalhe do reforço no consolo metálico: (a) detalhe do reforço no consolo embutido no pilar; (b) detalhe do reforço na ligação; (c) vista 3D da ligação com o reforço 


\section{LISTA DE TABELAS}

Tabela 2.1 - Valores do coeficiente de atrito da teoria do atrito-cisalhamento

Tabela 3.1 - Traço do concreto utilizado na confecção dos elementos prémoldados

Tabela 3.2 - Traço do concreto utilizado para preencher as ligações viga-pilar

Tabela 3.3 - Traço do concreto utilizado para executar a capa da laje

Tabela 3.4 - Resistência à compressão do concreto das vigas e do pilar.

Tabela 3.5 - Resistência à tração por compressão diametral do concreto das vigas e pilar.

Tabela 3.6 - Módulo de elasticidade tangente do concreto das vigas e pilar.

Tabela 3.7 - Resistência à compressão do concreto da ligação.

Tabela 3.8 - Resistência à tração por compressão diametral do concreto da ligação..

Tabela 3.9 - Módulo de elasticidade tangente do concreto da ligação.

Tabela 3.10 - Resistência à compressão do concreto da capa da laje.

Tabela 3.11 - Resistência à tração por compressão diametral do concreto da capa da laje.

Tabela 3.12 - Módulo de elasticidade tangente do concreto da capa da laje.

Tabela 3.13 - Propriedades mecânicas do aço das armaduras.

Tabela 3.14 - Propriedades mecânicas dos perfis metálicos.

Tabela 3.15 - Equipamentos e instrumentos de medição usados nos ensaios.

Tabela 3.16 - Convenção adotada para a numeração dos extensômetros

Tabela 3.17 - Procedimento de aplicação dos carregamentos nas duas etapas. 


\section{SUMÁRIO}

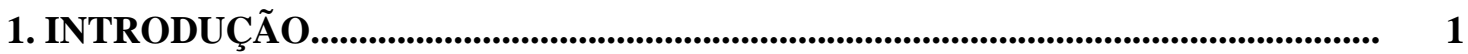

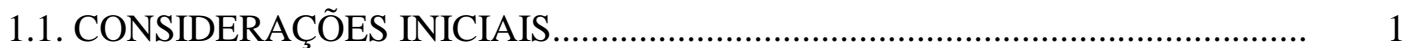

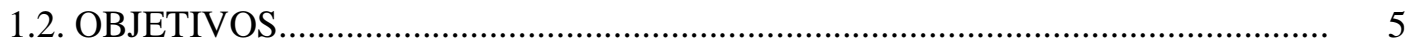

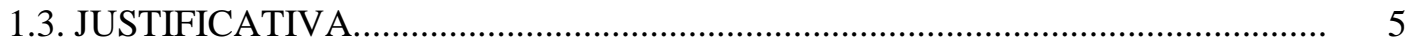

1.4. APRESENTAÇÃO DO TRABALHO..................................................................... 6

2. REVISÃO BIBLIOGRÁFICA ................................................................................... 7

2.1.GENERALIDADES ............................................................................. 7

2.2. PRINCIPAIS ESTUDOS REALIZADOS............................................................ 11

3. PROGRAMA EXPERIMENTAL ............................................................................. 33

3.1. CONSIDERAÇÕES INICIAIS...................................................................... 33

3.2. PROJETO DA LIGAÇÃO................................................................................. 33

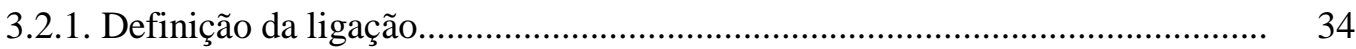

3.2.2. Especificação do concreto............................................................................. 35

3.2.3. Especificação do aço.................................................................................... 35

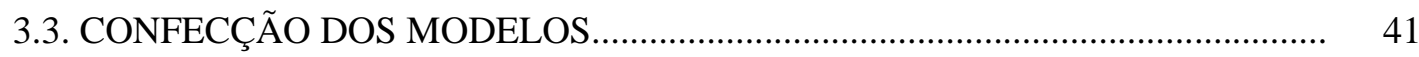

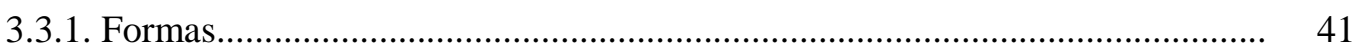

3.3.2. Armação dos elementos pré-moldados..............................................................

3.3.3. Concretagem dos elementos pré-moldados...................................................... 46

3.3.4. Montagem do modelo.................................................................................... 48

3.4. PROPRIEDADES MECÂNICAS DOS MATERIAIS............................................ 54

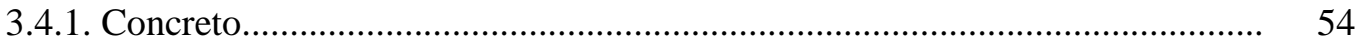

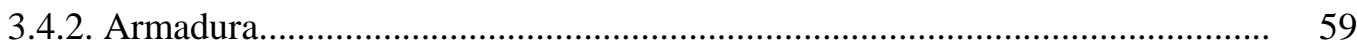

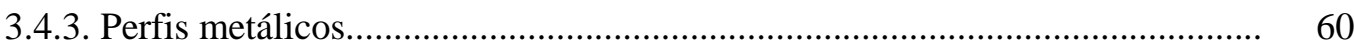

3.5. EQUIPAMENTOS E INSTRUMENTAÇÃO.................................................... 61

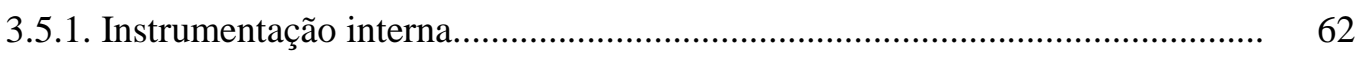

3.5.2. Instrumentação externa............................................................................. 65

3.6. PROCEDIMENTO DO ENSAIO..................................................................... 67

4. ANÁLISE DOS RESULTADOS........................................................................... 73

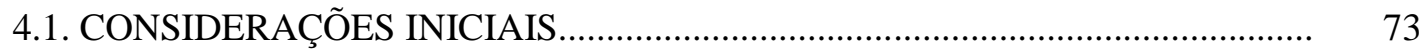

4.2. AVALIAÇÃO DA LIGAÇÃO REALIZADA..................................................... 73

4.3. RESULTADOS EXPERIMENTAIS ...................................................................... 74

4.3.1. Ensaio cíclico da primeira etapa..................................................................... 74

4.3.2. Ensaio monotônico da segunda etapa............................................................ 83

4.4. ANÁLISE DOS MECANISMOS DA LIGAÇÃO............................................... 92

4.4.1. Verificação da resistência do consolo metálico ao momento negativo junto à 
face do pilar 92

5. CONCLUSÕES....................................................................................................... 97

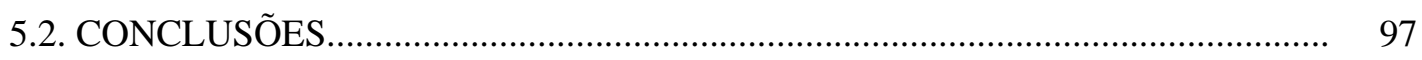

5.3. SUGESTÕES PARA PESQUISAS FUTURAS................................................ 98

6. REFERÊNCIAS BIBLIOGRÁFICAS...................................................................... 99 


\section{INTRODUÇÃO}

\subsection{CONSIDERAÇÕES INICIAIS}

As construções tem demandado atualmente um equilíbrio entre velocidade da obra, custos e qualidade. Com o uso de estruturas em concreto pré-moldado o processo construtivo acelerou e ganhou qualidade, entretanto sendo as estruturas produzidas em partes foi gerada a necessidade de fazer ligações para manter um comportamento global equivalente ao de uma estrutura monolítica.

As ligações nas estruturas de concreto pré-moldado são a parte fundamental para a análise estrutural. Existem variadas formas de ligação e métodos de análise, que afetam o comportamento de toda a estrutura.

O desempenho estrutural do sistema construtivo em concreto pré-moldado é dependente do comportamento das ligações. A configuração das ligações afeta a exequibilidade da construção, a estabilidade, a resistência e a deformabilidade da estrutura. As ligações possuem a importante função de dissipação de energia e redistribuição das cargas na estrutura carregada.

As regiões das ligações nas estruturas de concreto pré-moldado apresentam comportamento complexo, muitas vezes não se comportam da forma prevista na análise estrutural e conforme a complexidade podem gerar problemas na execução dos elementos estruturais e na montagem, perdendo a produtividade da obra, fator importante ao se adotar o sistema construtivo. 
Segundo EL DEBS (2000), as ligações são partes mais importantes no projeto das estruturas de concreto pré-moldado. São de fundamental importância para a produção e para o comportamento da estrutura montada.

Enquanto os elementos pré-moldados são produzidos nas fábricas com alto controle de qualidade normalmente as ligações, parte mais importante da estrutura, são executadas no local onde o controle de qualidade pode não ser o mesmo.

Devido ao fato de que com o aumento de carregamento e dos tipos de solicitações (flexão, cisalhamento, tensões axiais e torção), os conectores se tornam mais complexos e precisam possuir maior capacidade de absorver as tensões. Para atender às necessidades do mercado, são estudados diversos tipos de ligações para obter o melhor custo benefício da estrutura em geral, levando em consideração o desempenho estrutural, a facilidade de produção na fábrica, os recursos e tempo de montagem. O ideal é que a complexidade de execução da ligação seja na produção na fábrica, onde é possível obter maior controle e qualidade, evitando trabalhos de campo que possam comprometer a qualidade e segurança da estrutura.

Conforme ELLIOT (1996) o sucesso econômico e funcional das estruturas de concreto pré-moldado depende da configuração e propriedades das ligações. A flexibilidade das ligações afeta a fluência, distribuição térmica, as deformações por retração e determina o desempenho da junta no tempo. A ductilidade das ligações determina se as deformações permanentes implicarão em uma redistribuição segura das cargas e dissipação de energia, ou se acarretará na falha da ligação.

Seguindo as recomendações para o detalhamento e execução das ligações que permitam a continuidade total ou parcial do momento fletor, estruturas em concreto prémoldado podem apresentar comportamento muito semelhante ao de uma estrutura monolítica e com as vantagens do sistema construtivo de racionalização da construção e rapidez.

Este trabalho de pesquisa é uma variação do projeto de pesquisa em nível de doutorado de OLIVEIRA JÚNIOR (2009).

O modelo de OLIVEIRA JUNIOR (2009) está apresentado na Figura 1.1. 


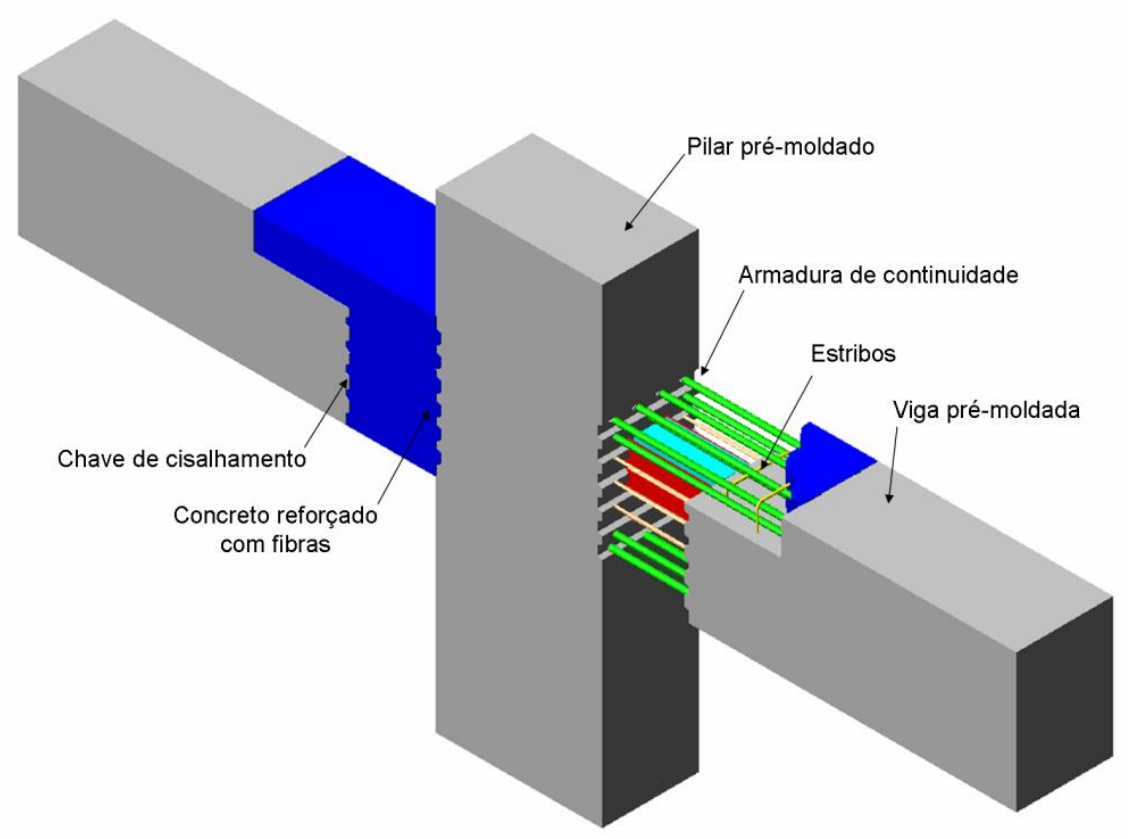

(a) Esquema geral

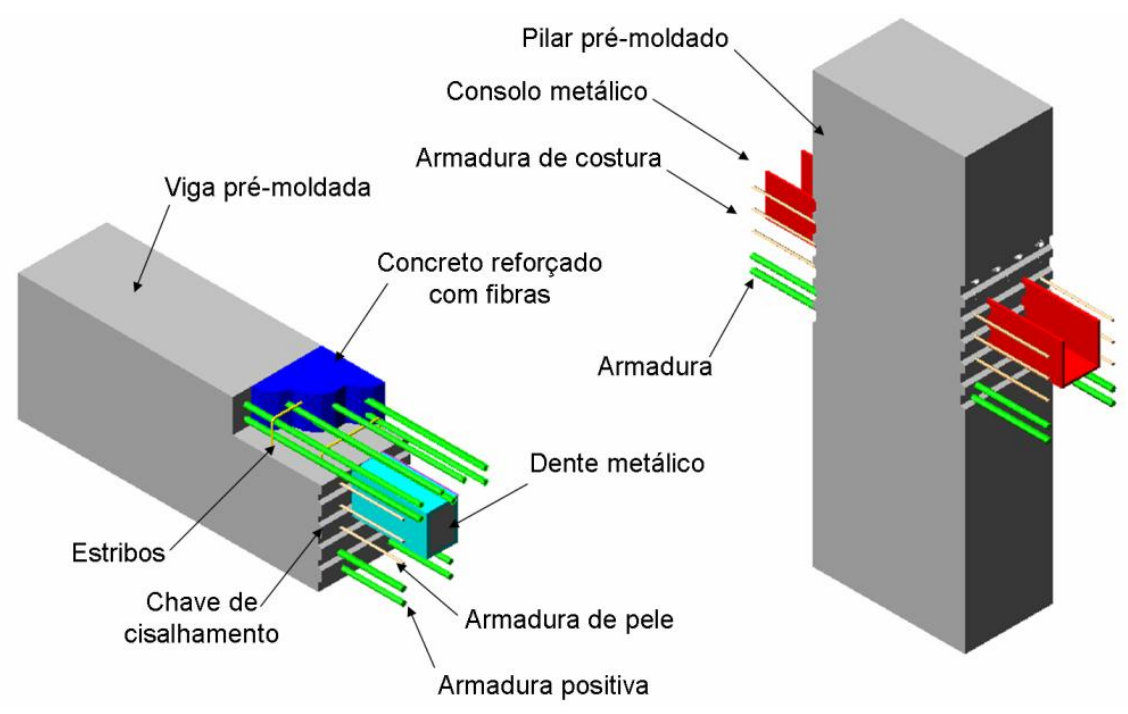

(b) Componentes da ligação

Figura 1.1 - Esboço do modelo de ligação proposto no projeto de pesquisa OLIVEIRA JUNIOR (2009): (a) Esquema geral e (b) Componentes da ligação.

Neste modelo a continuidade ao momento fletor é promovida mediante emenda de barras da armadura positiva e da armadura negativa passante no pilar, neste caso as armaduras negativas serão inseridas no momento da montagem, sendo rosqueadas em insertos deixados no pilar. Para garantir a estabilidade lateral na situação transitória o dente metálico da viga é soldado no consolo metálico embutido no pilar. A ligação definitiva é realizada por meio de concretagem com concreto com fibras de aço para recompor a seção transversal da viga prémoldada e poder reduzir o comprimento de traspasse. 
Com base no projeto de OLIVEIRA JUNIOR (2009), foi proposto avaliar o comportamento de uma ligação viga pilar por meio de um consolo metálico embutido no pilar em perfil "U" e dentes metálicos embutidos em cada viga em perfil tubular retangular, soldados para permitir a continuidade do momento fletor negativo e por meio de cantoneiras metálicas embutidas no pilar soldadas nas barras da armadura positiva da viga para resistir ao momento fletor positivo. A ligação pode ser solicitada por carregamento estático monotônico ou cíclico reversível. Essa ligação será preenchida com concreto moldado no local. A Figura 1.2 apresenta uma ilustração do modelo de ligação estudado.

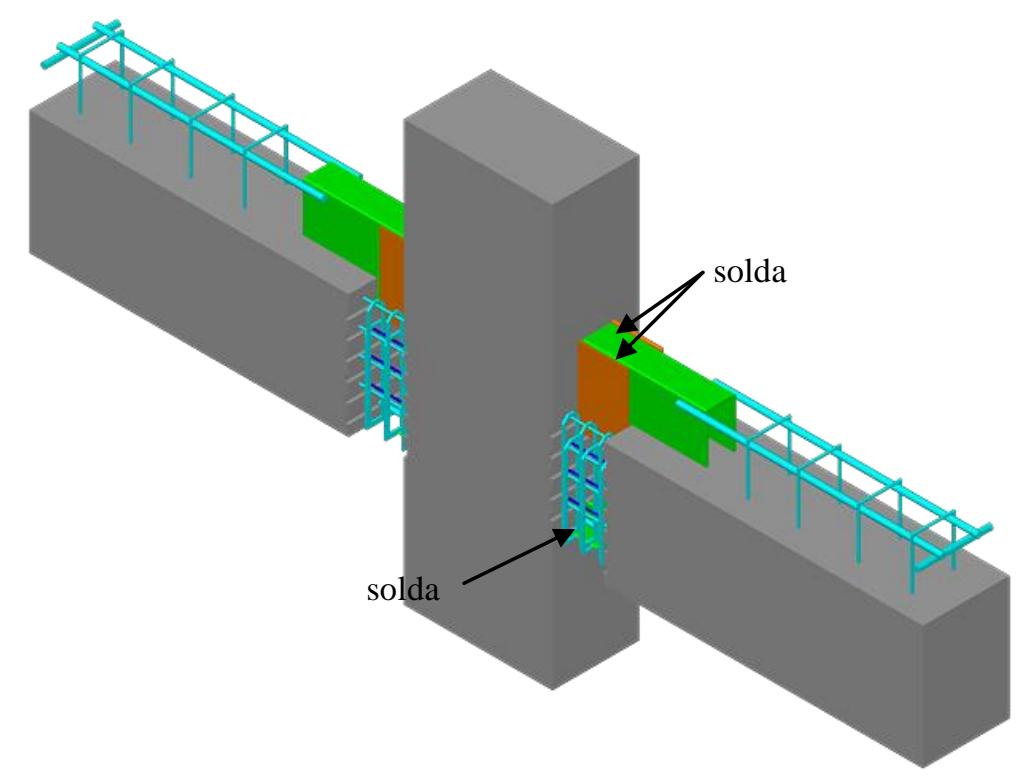

Figura 1.2 - Esquema de ligação estudada.

Um diferencial desta ligação é que os perfis metálicos embutidos no pilar e na viga serão soldados com solda horizontal de filete com o eletrodo posicionado de cima para baixo, o que é uma vantagem, pois facilita a execução pelo soldador e reduz a possibilidade de erros. Segundo BRUGGELING e HUYGHE (1991) a habilidade dos soldadores no campo é de fundamental importância e os inspetores devem estar atentos aos detalhes que podem causar defeitos na solda. A solda dos insertos metálicos será responsável por resistir ao momento fletor na região da ligação o que possibilitará dispensar a ligação da armadura negativa da viga no pilar reduzindo a taxa de armadura e facilitando a execução. 


\subsection{OBJETIVOS}

O objetivo desta pesquisa é analisar experimentalmente o comportamento à flexão de uma ligação viga-pilar, entre elementos de concreto pré-moldado, por meio de insertos metálicos soldados, e preenchida com concreto. A ligação será solicitada por ações estáticas monotônica e cíclica reversível.

Como objetivos específicos, têm-se:

a) Será avaliada a tração causada por momento fletor através da solda entre os dispositivos metálicos permitindo reduzir ou até mesmo dispensar a armadura para essa finalidade;

b) Verificar a exeqüibilidade da ligação e o quanto ela pode alterar o andamento da obra, e propor uma forma apropriada para montagem dos elementos;

c) Analisar as características mecânicas quanto à resistência e deformação dos componentes da ligação quando solicitada por momento fletor, submetida a carregamento estático monotônico e cíclico reversível;

d) Propor um modelo analítico simplificado que represente de forma satisfatória o comportamento da ligação, para que possa ser aplicado em projeto.

\subsection{JUSTIFICATIVA}

Fornecer mais uma alternativa de ligação viga pilar resistente a momento fletor.

O esquema de ligação entre os perfis metálicos possibilita uma execução mais fácil da solda, que é uma vantagem para garantir a qualidade no campo. Pode-se aproveitar dessa vantagem para reduzir a taxa de armadura na ligação, dimensionando os perfis para resistirem às tensões de tração geradas pela flexão dos elementos estruturais.

O trabalho é de interesse da indústria de pré-moldados em geral, que tem nos estudos sobre o comportamento da ligação a possibilidade de conhecer mais a fundo o desempenho das estruturas em concreto pré-moldado.

Com os resultados dos ensaios podem-se obter modelos teóricos simplificados que sejam satisfatórios em representar o comportamento da ligação para a aplicação em projetos. 


\subsection{APRESENTAÇÃO DO TRABALHO}

No Capítulo 1 (Introdução): é apresentado o contexto da pesquisa em questão, a proposta do trabalho experimental, os objetivos e as justificativas do trabalho.

No Capítulo 2 (Revisão bibliográfica): são mostradas diversas pesquisas em ligações em concreto pré-moldado com características semelhantes à proposta do trabalho, também se apresenta modelos de cálculo nas situações transitórias e definitiva.

No Capítulo 3 (Programa experimental:) são expostas as características do modelo experimental, projeto da ligação, especificações do aço e concreto. É apresentada a forma de confecção dos elementos pré-moldados, montagem do modelo, propriedades mecânicas dos materiais obtidas através dos ensaios de caracterização, instrumentação utilizada e procedimento ensaio.

No Capítulo 4 (Análise dos resultados): analisa-se a resistência do modelo pelas forças últimas nos componentes da ligação e deformação das armaduras dos perfis metálicos, também é analisado o quadro de fissuração e forma de ruptura.

No Capítulo 5 (Considerações finais e conclusão): apresentam-se as conclusões do presente trabalho e sugestões para trabalhos futuros. 


\section{REVISÃO BIBLIOGRÁFICA}

\subsection{GENERALIDADES}

As estruturas em concreto pré-moldado usualmente são projetadas com ligações articuladas devido à facilidade na execução e na montagem dos elementos estruturais. Porém, dessa forma, a responsabilidade quanto à estabilidade global do edifício recai sobre os pilares engastados na fundação ou sistemas de contraventamento, onerando obras com mais de 3 pavimentos.

O sistema construtivo de estruturas de concreto pré-moldado é caracterizado pela facilidade de execução e montagem dos elementos, e também pelo menor tempo necessário para concluir a estrutura de uma obra. Um dos fatores limitantes das vantagens da utilização desse sistema é realizar as ligações, pois quando se pretende, por alguma necessidade, adotar tipologias de ligações mais difíceis de executar, o tempo para conclusão da obra e o risco de ocorrerem não conformidades tornam-se maiores. Portanto é imprescindível elaborar projetos de pesquisas de novas formas de ligações que sejam fáceis de executar e se comportem de maneira eficiente para diversas utilizações de edifícios.

O detalhamento das ligações é uma das partes mais importantes do projeto de estruturas de concreto pré-moldado para o sucesso da construção. O comportamento da ligação afeta a resistência, a estabilidade e a exequibilidade do sistema estrutural, pois são responsáveis pela transferência das cargas. 
São nas ligações entre elementos pré-moldados que ocorrem os principais problemas do sistema construtivo. A resposta da estrutura depende do comportamento e das características das ligações. Desejando-se obter melhor comportamento estrutural quanto à distribuição dos momentos fletores, por exemplo, necessita-se de ligações mais complexas e quanto maior a complexidade da ligação, maior a possibilidade de ocorrência de erros, sejam eles no modelo adotado para prever o comportamento da ligação ou na execução.

O problema e dificuldade das ligações que transmitem momento fletor é que, pelo fato do concreto armado ser um material composto, torna-se necessário fazer a ligação tanto do concreto quanto do aço. Outro problema é que o concreto é um material frágil, EL DEBS (2000).

As ligações nas estruturas podem ser classificadas da seguinte forma quanto a deformação:

a. Ligações articuladas: não se deformam;

b. Ligações semi-rígidas: comportamento intermediário quanto a deformação;

c. Ligações rígidas: se deformam.

As ligações viga-pilar articuladas mais comuns em elementos de concreto prémoldado são utilizando consolo no pilar e, convenientemente, dentes nas vigas. Esses elementos são dimensionados de formas diferentes conforme seu comprimento. Quando longos são dimensionados como vigas, quando curtos utiliza-se o modelo de bielas e tirantes, e quando muito curtos a verificação é feita pelo modelo de atrito-cisalhamento. A Figura 2.1 apresenta o caminho das cargas nesses elementos para o modelo de bielas e tirantes, com aplicação de carregamento direto. 

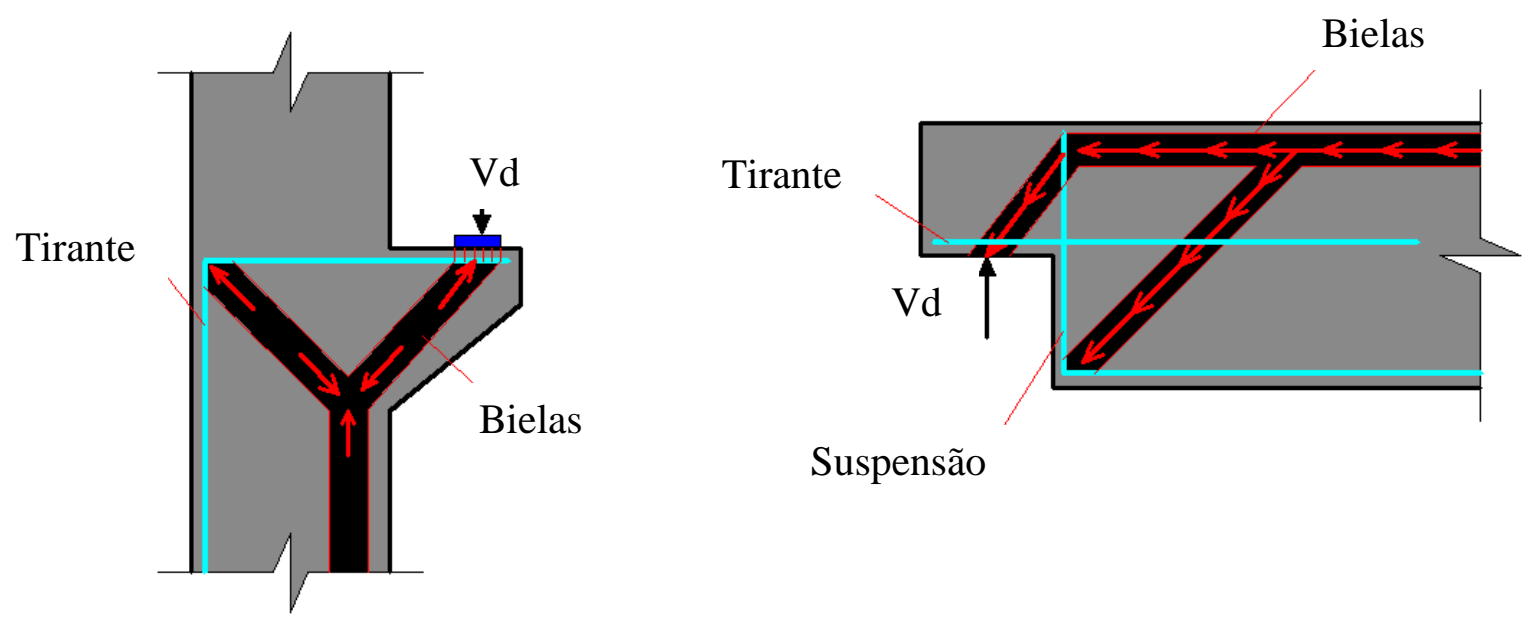

Suspensão

Figura 2.1 - Detalhe do modelo de bielas e tirantes aplicado no consolo do pilar e no dente da viga.

Nesse modelo, a compressão na biela comprimida deve ser resistida pela resistência à compressão do concreto e as tensões de tração nos tirantes devem ser resistidas pela armadura.

Conforme EL DEBS (2000) as ligações rígidas podem ser realizadas por meio de conectores metálicos e solda, com emendas das armaduras da viga e do pilar ou com cabos de protensão. É mais comum realizar conexões com solda, ou a armadura da viga atravessando o pilar para obter rigidez. Há certo problema em se utilizar solda nas ligações, pois existem dificuldades no campo para se manter a qualidade da solda e também em ocasião de solicitação com grande número de repetições ocorre a redução da resistência da solda.

Esse tipo de ligação permite uma estrutura menos solicitada a momentos fletores, porém é mais difícil e necessita de maior tempo para a execução. O CEB-FIP (2008) fornece alguns motivos para a utilização de ligações rígidas, apresentados abaixo.
a. Reduzir as dimensões dos elementos;
b. Distribuir os momentos de segunda ordem e reduzir os momentos nos pilares;
c. Prover resistência ao colapso progressivo;
d. Redução das flechas.

Reduzindo as dimensões dos elementos pode-se conseguir economia de materiais e de transporte, pois é possível transportar mais peças em uma mesma viagem reduzindo o número de viagens. 
Muitos estudos sobre ligações em diversos países foram realizados devido às dificuldades de implantação de estruturas de concreto pré-moldado em regiões sísmicas. A resposta inadequada da estrutura quando submetida a ações sísmicas é causada pelo comportamento das ligações mais simples, que são mais utilizadas, não ser apropriado.

Conforme VASCONEZ et al. (1998) o desenvolvimento da metodologia para projeto e construção de estruturas de concreto pré-moldado em zonas altamente sísmicas tem sido conduzido na Universidade de Michigan nos Estados Unidos através da National Science Foundation (NSF) pelo programa de pesquisa "Precast Seismic Structural Systems" (PRESSS) patrocinado pela NSF e pelo Precast/Prestressed Concrete Institute (PCI).

Outro programa que procurou estudar o comportamento de ligações em estruturas de concreto pré-moldado foi o "Control of Semi-rigid Behaviour of Civil Engineering Structural Connections" (COST C1). Este programa foi desenvolvido pela Comunidade Européia entre 1991 e 1998 com o objetivo de formar grupos de pesquisa para estudar ligações semi-rígidas em diversos tipos de estruturas: metálicas, de madeira, de concreto armado e protendido e estruturas mistas.

Cheok e Lew (1991) afirmam que pela falta de dados sobre as ligações viga pilaras estruturas pré-moldadas tendem a ser presumidas como menos dúcteis e estáveis que estruturas monolíticas.

Segundo Leon (1998), no início da década de 50 as ligações semi-rígidas ou de resistência parcial eram incorporadas a projetos através do método simplificado permitidos pelas normas AISC conhecido por "ligações inteligentes", uma vez que as ligações eram capazes de diferenciar os momentos provocados por carregamentos gravitacionais e laterais.

Neste modelo, as ligações eram supostas articuladas sobre carregamento gravitacional e supostas rígidas ou de resistência total quando submetidas a carregamentos laterais (vento). Para análise em serviços as ligações eram consideradas rígidas.

Estudos comparando o método simplificado das ligações inteligentes com procedimentos rigorosos de análise estrutural para estado limite de serviço e estado limite últimos comprovaram que tal método apresenta resultados perfeitamente satisfatórios.

Outros métodos para incorporação do comportamento semi-rígido foram desenvolvidos, contudo a forma mais usual para levar em consideração o comportamento semi-rígido é utilizando os parâmetros de deformabilidade ou rigidez e resistência última das ligações extraídas de curvas forças-deslocamento. 
Em FERREIRA (1993) foi sistematizado o método dos "Mecanismos Básicos de Deformação", no qual o equacionamento para o cálculo da deformabilidade da ligação é resultante da associação dos mecanismos internos de deformação. São apresentados modelos de cálculo para a determinação das deformabilidades à flexão, ao cisalhamento e à força normal de diferentes ligações típicas. Em FERREIRA (1999), alguns modelos analíticos foram comparados e calibrados com resultados de ensaios de ligações viga-pilar. Os modelos analíticos desenvolvidos previamente à realização dos ensaios forneceram parâmetros que foram analisados nos ensaios.

FERREIRA (2001) propôs um modelo de cálculo para projeto de ligações semirígidas, onde as ligações devem atender aos requisitos de resistência e de rigidez. Tal procedimento foi aplicado para diferentes tipologias de ligações resistentes à flexão, onde os valores teóricos obtidos foram confrontados com resultados experimentais já existentes obtidos em FERREIRA (1999), em STANTON et al. (1986) e em GORGUN (1997), onde foram encontradas boas correlações para todas as ligações avaliadas.

Por exemplo, segundo BALDISSERA (2006) as ligações semi-rígidas entre elementos pré-moldados são consideradas muitas vezes como articuladas ou rígidas, desconsiderando a rigidez real da ligação. Isso ocorre devido à dificuldade de propor modelos analíticos simplificados para representar o comportamento da ligação, pois é necessário obter valores experimentais de deformabilidade e resistência para adequar os modelos.

\subsection{PRINCIPAIS ESTUDOS REALIZADOS}

Muitos dos modelos estudados de ligações resistentes a momento fletor utilizando elementos metálicos, em um determinado período, nas situações transitórias as ligações são consideradas articuladas. Pensando na simplicidade e viabilidade de execução, MARCAKIS e MITCHELL (1980) propuseram a utilização de consolo metálico no pilar, ao invés do tradicional consolo de concreto. Esse sistema dispõe de diversas vantagens, como a de não necessitar de detalhes complicados de armadura e de poderem ser facilmente dimensionados.

O modelo de MARCAKIS e MITCHELL (1980) integra o manual "PCI Design Handbook", PCI (2004). Este manual apresenta diversos tipos de consolo metálico embutido no pilar, conforme mostrado na Figura 2.2. 

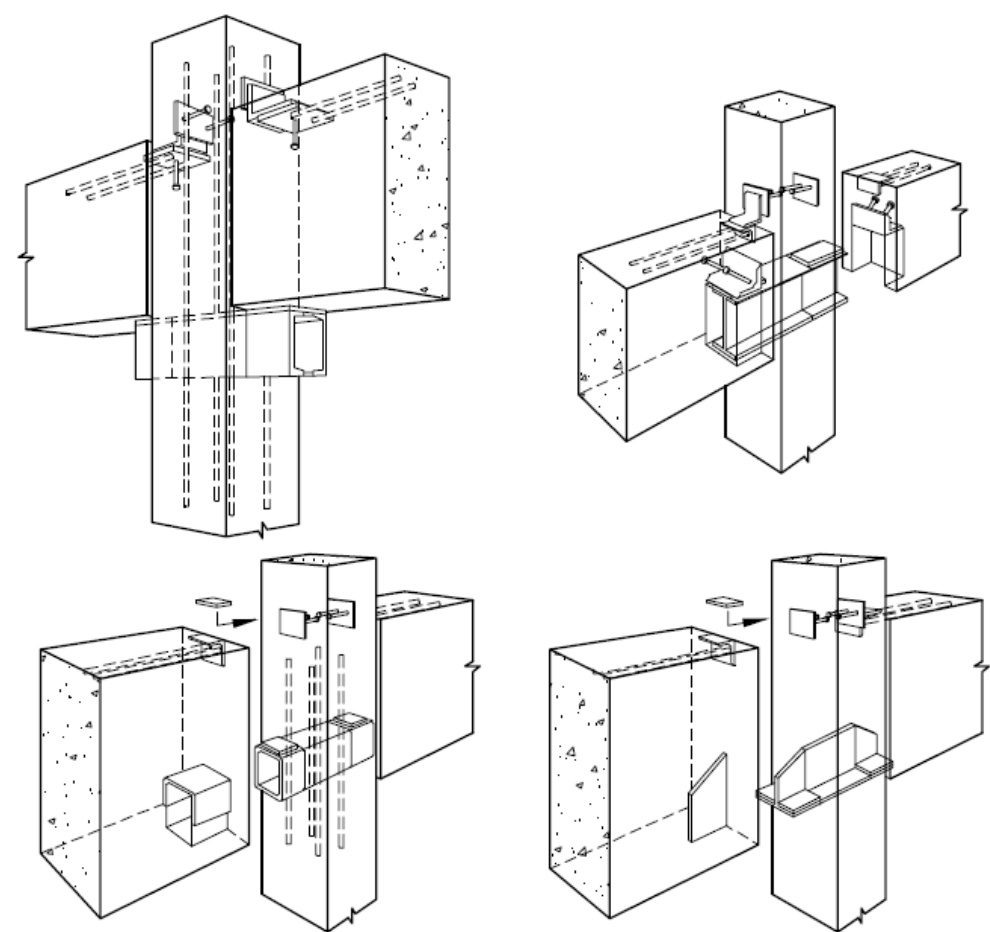

Figura 2.2 - Tipos de consolo metálico embutido no pilar.

Fonte: PCI (2004).

Nesses modelos a borda superior das vigas é soldada em chapas deixadas no pilar para manter a estabilidade lateral, mas dessa forma a estrutura pode assumir um comportamento semirígido.

O modelo proposto e as hipóteses para dimensionamento estão mostrados na Figura 2.3 extraída do PCI (2004).
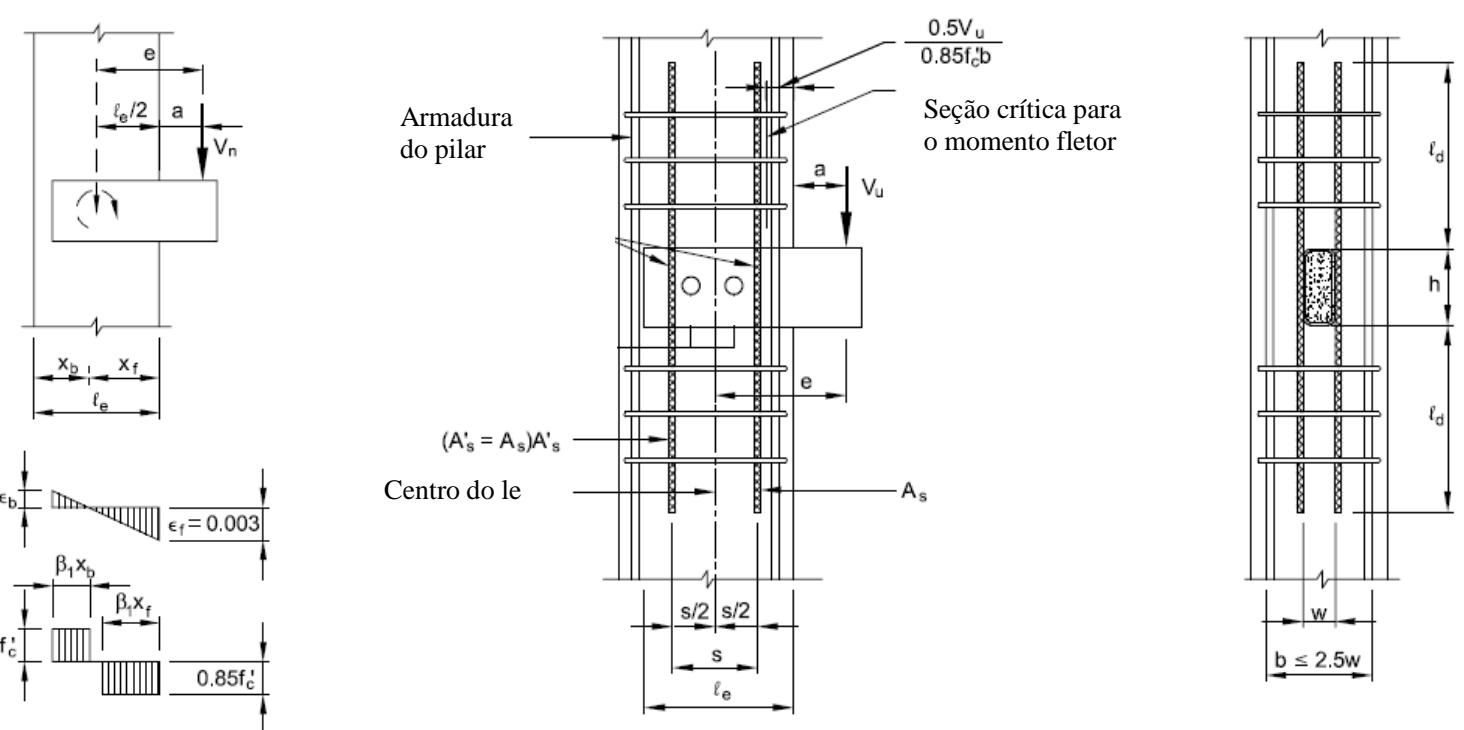

Figura 2.3 - Hipóteses para verificação do consolo metálico assimétrico embutido no pilar. Fonte: PCI (2004). 
Neste modelo podem existir barras soldadas ao consolo, internamente ao pilar, para haver uma melhor distribuição de tensões e aliviar o concreto. Apesar de que apenas uma parte das armaduras soldadas trabalha à tração, e a outra parte não é eficiente, essas barras precisam ser simétricas para evitar erros de execução que podem acarretar em um comportamento não condizente com o dimensionamento.

O PCI (2004) fornece as parcelas de resistência última do concreto e das barras da armadura.

\section{Parcela resistida pelo concreto:}

$$
V_{c u}=\frac{0,85 f_{c d} b l_{e}}{1+3,6\left(e / l_{e}\right)}
$$

\section{Parcela resistida pela armadura:}

$$
V_{s u}=\frac{2 A_{s} f_{y d}}{1+\frac{6\left(e / l_{e}\right)}{4,8\left(s / l_{e}\right)-1}}
$$

$b \rightarrow$ largura que pode ser considerada igual à da região interna da armadura do pilar, se o espaçamento das barras for menor que $75 \mathrm{~mm}$, mas não deve ser superior a 2,5w;

$A_{s} \rightarrow$ é a área da armadura adicional soldada de cada um dos lados do perfil;

$l_{e} \rightarrow$ é o comprimento embutido do consolo metálico no pilar.

$$
l_{\text {emin }}=a+\frac{0,5 V_{d}}{0,85 f_{c d} b}
$$

A segunda parcela de ${ }^{l_{e, \min }}$ é a posição da seção crítica de aplicação do momento.

O elemento metálico deve ser verificado à flexão e ao cisalhamento, conforme abaixo:

Flexão no perfil metálico:

$$
V_{n}=\frac{Z_{s} f_{y s d}}{a+\frac{0,5 V_{d}}{0,85 f_{c d} b}}
$$

\section{Cisalhamento no perfil metálico:}

$$
V_{n}=0,6 f_{y s d} h t
$$

$Z_{s} \rightarrow$ é o módulo plástico da seção transversal do perfil metálico;

$h_{\mathrm{e}} t \rightarrow$ são a altura e a espessura das almas do perfil metálico respectivamente.

A força horizontal pode ser resistida por aderência, considerando a superfície de contato do elemento metálico, até uma tensão última de aderência de 1,72 $\mathrm{MPa}$. 
Conforme EL DEBS (2000), recomenda-se que seja verificada a possibilidade de fendilhamento do pilar junto ao consolo, devido a ocorrer uma situação de bloco parcialmente carregado. Mesmo que não seja necessária armadura de cisalhamento, deve ser providenciada uma quantidade maior de estribos junto ao consolo.

Para o mesmo tipo de consolo, BRUGGELING e HUYGHE (1991) apresentaram a seguinte equação para considerar a parcela resistida pelo concreto:

$$
V_{c u}=\frac{0,85 f_{c d} b l_{e}}{\left[3,7+4\left(4 / l_{e}\right)\right]}
$$

O PCI (2004) também apresenta um modelo de dente para a viga utilizando elemento metálico.

O PCI (2004) propõe duas formas de detalhe para o dente metálico embutido na viga, são elas: "CazalyHanger", suspensão com elemento metálico, e "LoovHanger", suspensão com elemento metálico curto. Será apresentado o modelo "CazalyHanger" que foi utilizado no trabalho. Para suspensão pode-se utilizar uma cinta metálica. EL DEBS (2000) relata que a mesma formulação pode ser empregada quando se utilizam barras em vez da cinta metálica, tomando as devidas precauções. O PCI (2004) apresenta o modelo da Figura 2.4 (“CazalyHanger”) para a verificação do dente.

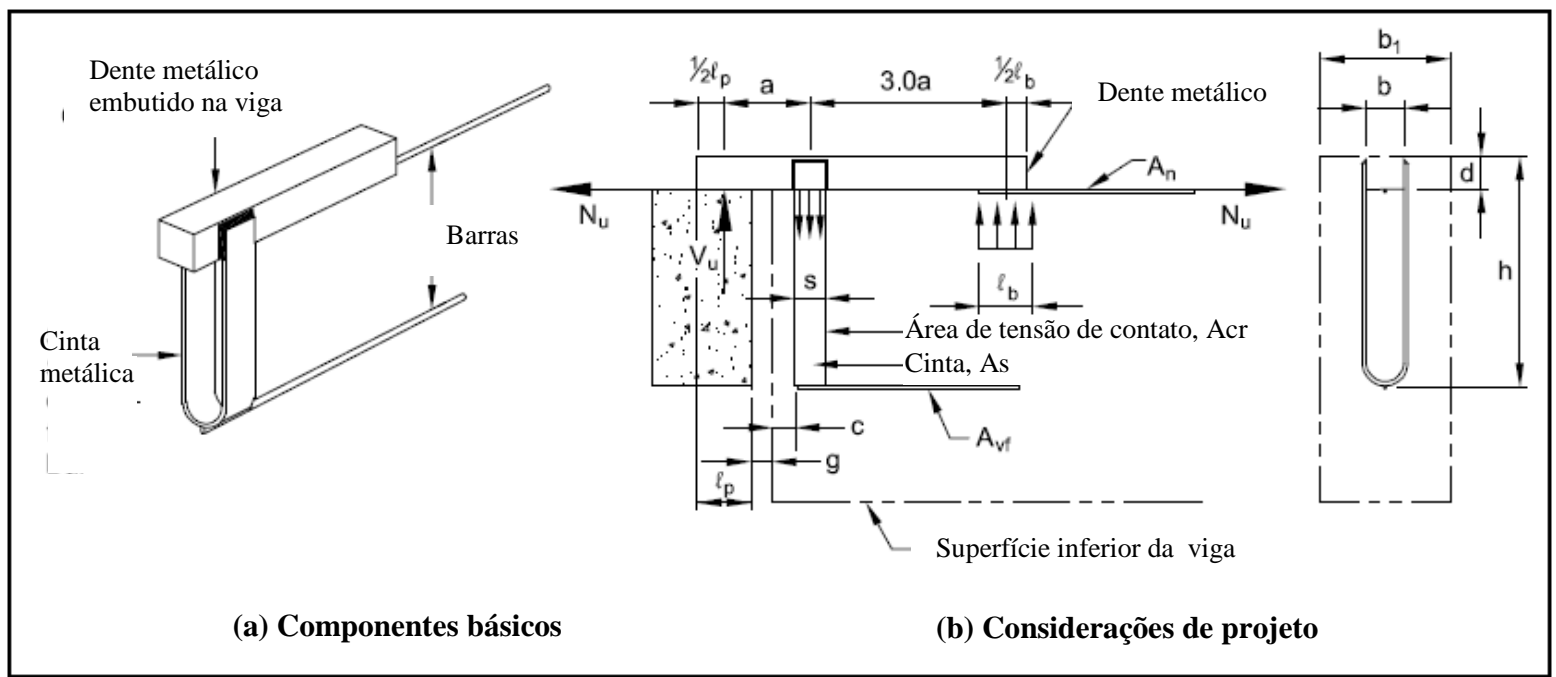

Figura 2.4 - Esquema “CazalyHanger” e hipóteses de distribuição das tensões e das forças.

Fonte: PCI (2004). 
Os itens a serem verificados e dimensionados estão apresentados abaixo.

Cálculo da área da armadura de suspensão:

$$
A_{s}=\frac{4}{3} \frac{V_{u}}{f_{y d}}
$$

\section{Verificação da tensão de contato no concreto:}

$$
\begin{gathered}
\sigma_{c}=\frac{V_{u}}{3 b l_{b}} \leq \sigma_{u}=0,85 f_{c d} \sqrt{\frac{b_{1}}{b}} \leq 1,2 f_{c d} \\
l_{b}=\frac{V_{u}}{3 b \sigma_{u}}
\end{gathered}
$$

\section{Comprimento mínimo do perfil metálico:}

$$
l_{\text {perfil }}=\frac{1}{2} l_{p}+a+3,0 a+\frac{1}{2} l_{b}=\frac{5}{2} l_{p}+4,0 g+4,0 c+2,0 s+\frac{1}{2} l_{b}
$$

Área da armadura soldada ao perfil metálico:

$$
A_{n}=\frac{N_{u}}{f_{y d}}
$$

Área da armadura adicional soldada à cinta metálica de suspensão:

$$
A_{v f}=\frac{4}{3} \frac{V_{u}}{f_{y d} \mu_{e f}}
$$

Essa armadura é calculada pelo modelo de atrito-cisalhamento utilizando o coeficiente

\begin{tabular}{|c|c|c|c|c|}
\hline & Crack interface condition & Recommended $\mu$ & Maximum $\mu_{e}$ & Maximum $V_{u}=\phi V_{n}$ \\
\hline 1. & $\begin{array}{l}\text { Concrete to concrete, cast } \\
\text { monolithically }\end{array}$ & $1.4 \lambda$ & 3.4 & $0.30 \lambda^{2} \mathrm{f}_{\mathrm{c}}^{\prime} \mathrm{A}_{\mathrm{cr}} \leq 1000 \lambda^{2} \mathrm{~A}_{\mathrm{cr}}$ \\
\hline 2. & $\begin{array}{l}\text { Concrete to hardened concrete, } \\
\text { with roughened surface }\end{array}$ & $1.0 \lambda$ & 2.9 & $0.25 \lambda^{2} \mathrm{f}_{\mathrm{c}}^{\prime} \mathrm{A}_{\mathrm{cr}} \leq 1000 \lambda^{2} \mathrm{~A}_{\mathrm{cr}}$ \\
\hline & Concrete to concrete & $0.6 \lambda$ & 2.2 & $0.20 \lambda^{2} \mathrm{f}_{\mathrm{c}}^{\prime} \mathrm{A}_{\mathrm{cr}} \leq 800 \lambda^{2} \mathrm{~A}_{\mathrm{cr}}$ \\
\hline & Concrete to steel & $0.7 \lambda$ & 2.4 & $0.20 \lambda^{2} \mathrm{f}_{\mathrm{c}}^{\prime} \mathrm{A}_{\mathrm{cr}} \leq 800 \lambda^{2} \mathrm{~A}_{\mathrm{cr}}$ \\
\hline
\end{tabular}
de atrito $\mu_{e f}$, calculado da seguinte forma, segundo o PCI (2004):

$$
\mu_{e f}=\frac{6904 \lambda^{2} A_{c r} \mu}{V_{u}} \leq \max \mu_{e f}
$$

Os valores de $\mu$ e $\mathrm{m}^{\max \mu_{e f}}$ são recomendados na Tabela 2.1 fornecida pelo PCI (2004) com a situação de interface entre concretos moldados monoliticamente.

Tabela 2.1 - Valores do coeficiente de atrito da teoria do atrito-cisalhamento. 


\section{Verificação da flexão no perfil metálico:}

$$
M_{d}=V_{u} a \leq M_{R d}=Z_{s} f_{y s d}
$$

Verificação do cisalhamento no perfil metálico:

$$
V_{d} \leq V_{n}=0,6 f_{y s d} h t
$$

OLIVEIRA JÚNIOR (2009) realizou a análise numérica de uma ligação viga pilar em concreto pré-moldado na fase de montagem e comparou com os resultados analíticos conforme os modelos apresentados pelo PCI (2004) descritos acima neste trabalho.

O modelo de ligação viga pilar de OLIVERIA JÚNIOR (2009) consiste em um consolo metálico com seção transversal em "U”" embutido no pilar, constituído por chapas de açosoldadas para travar lateralmente o dente metálico embutido na viga formado por um tubo de seçãotransversal retangular, o qual será posteriormente fixado ao consolo por solda de filete.Para fazer com que a ligação apresente um comportamento o mais próximo possíveldaquele apresentado por uma ligação monolítica, a continuidade ao momento fletor serápromovida mediante emenda de barras da armadura positiva e da armadura negativapassante no pilar. A ligação definitiva será realizada por meio de concretagem comconcreto reforçado com fibras de aço para recompor a seção transversal da vigaprémoldada. As seções do consolo e do dente foram escolhidas de modo que o dente seja travado lateralmente pelo consolo permitindo maior estabilidade na fase de montagem.

A Figura 2.5 ilustra o modelo de ligação de OLIVEIRA JÚNIOR (2009) fase de montagem e definitivo.

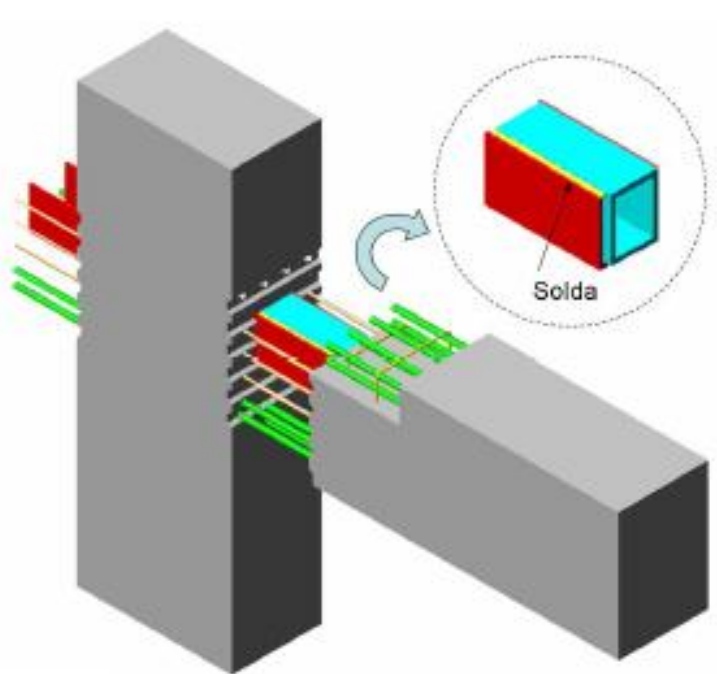

(a)

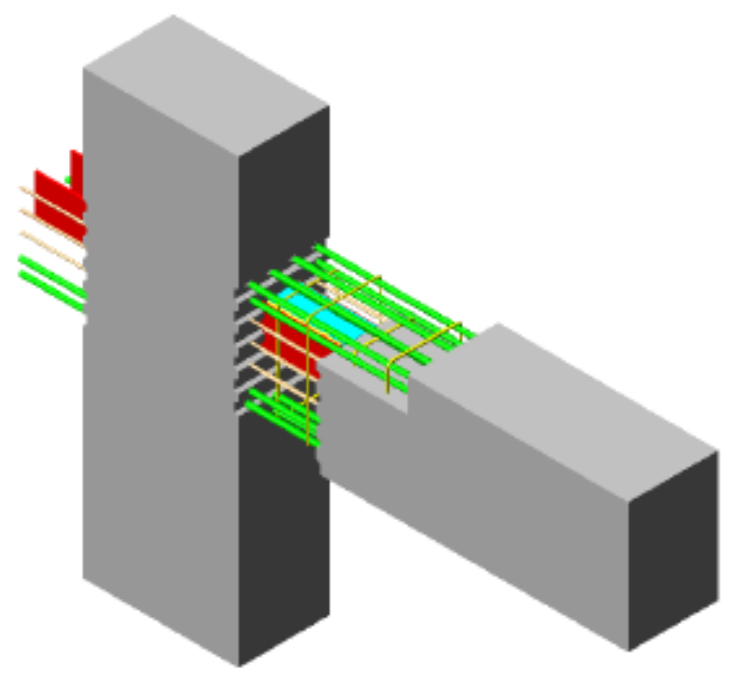

(b)

Figura 2.5 - Modelo de ligação de OLIVEIRA JÚNIOR (2009): a) fase de montagem, b) fase definitiva antes da concretagem da ligação. 
Neste modelo, para a fase definitiva, em que a ligação deverá resistir ao momento fletor, a armadura negativa e a armadura de costura são rosqueadas em insertos deixados no pilar e são montados os estribos para confinar o concreto da ligação.

Da análise numérica, OLIVEIRA JÚNIOR (2009) conferiu que em seu modelo a ruptura ocorreu por flexão do consolo metálico e que nesse caso a formulação do PCI (2004) indica uma resistência $57 \%$ inferior que a última força de convergência do modelo computacional, portanto o modelo analítico do PCI (2004) é muito conservador e subestima a capacidade resistente da ligação.

O CEB-FIP (2008) apresenta um modelo de ligação resistente a momento fletor utilizando dispositivos metálicos soldados. Esse modelo de ligação consiste em uma chapa metálica ancorada na viga usando barras de armadura. Essa chapa é soldada com solda de penetração total em um elemento metálico embutido no pilar, como um consolo. Para resistir ao momento negativo, são passadas armaduras através do pilar por furos deixados neste. A ligação é preenchida com concreto e após a montagem da laje, a armadura negativa é coberta pelo concreto da capa. A Figura 2.6 a) e b) ilustra o modelo apresentado no manual de ligações do CEB-FIP (2008) antes da concretagem da ligação e após a montagem da armadura negativa.
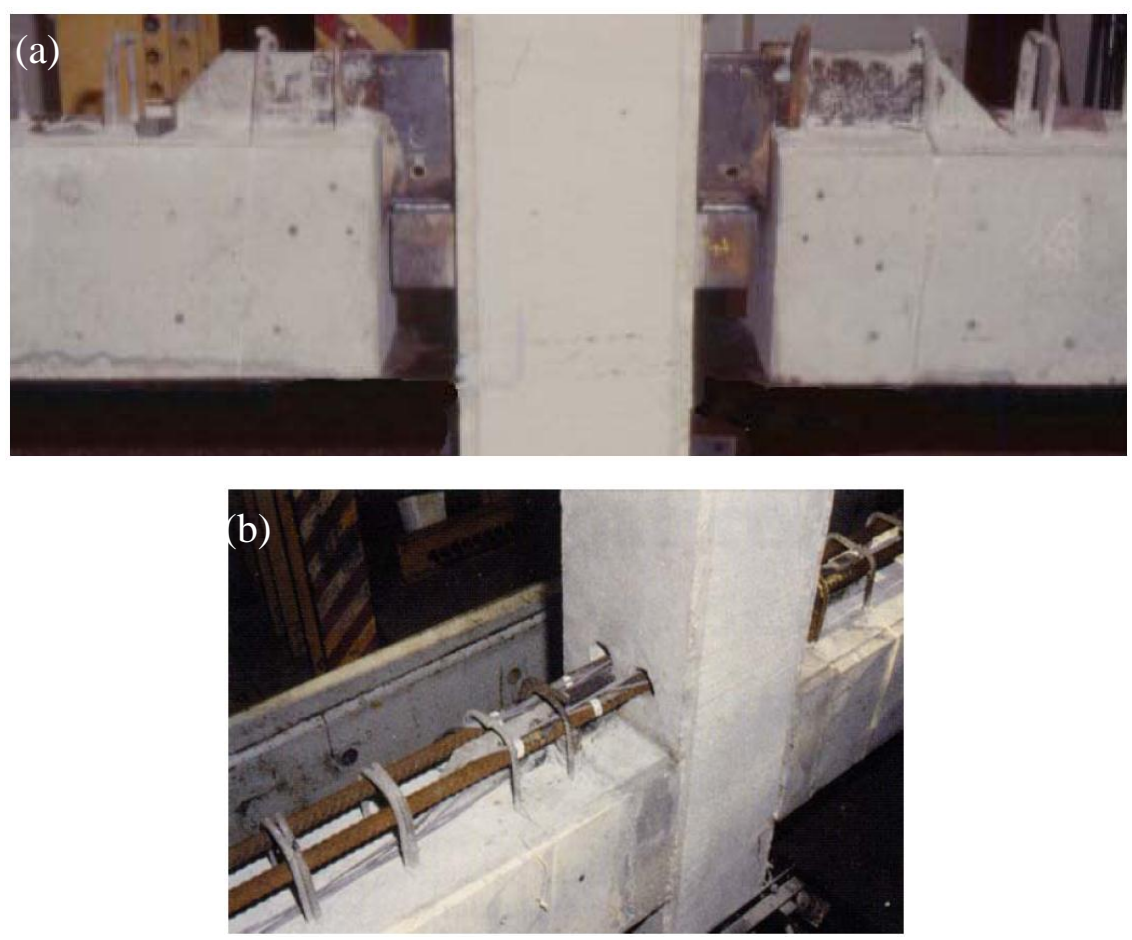

Figura 2.6 - Modelo apresentado pelo CEB-FIP (2008): a) elementos metálicos soldados, b) armadura negativa atravessando o pilar. 
A Figura 2.7 mostra os componentes da ligação e as forças atuantes quando solicitada ao momento negativo.

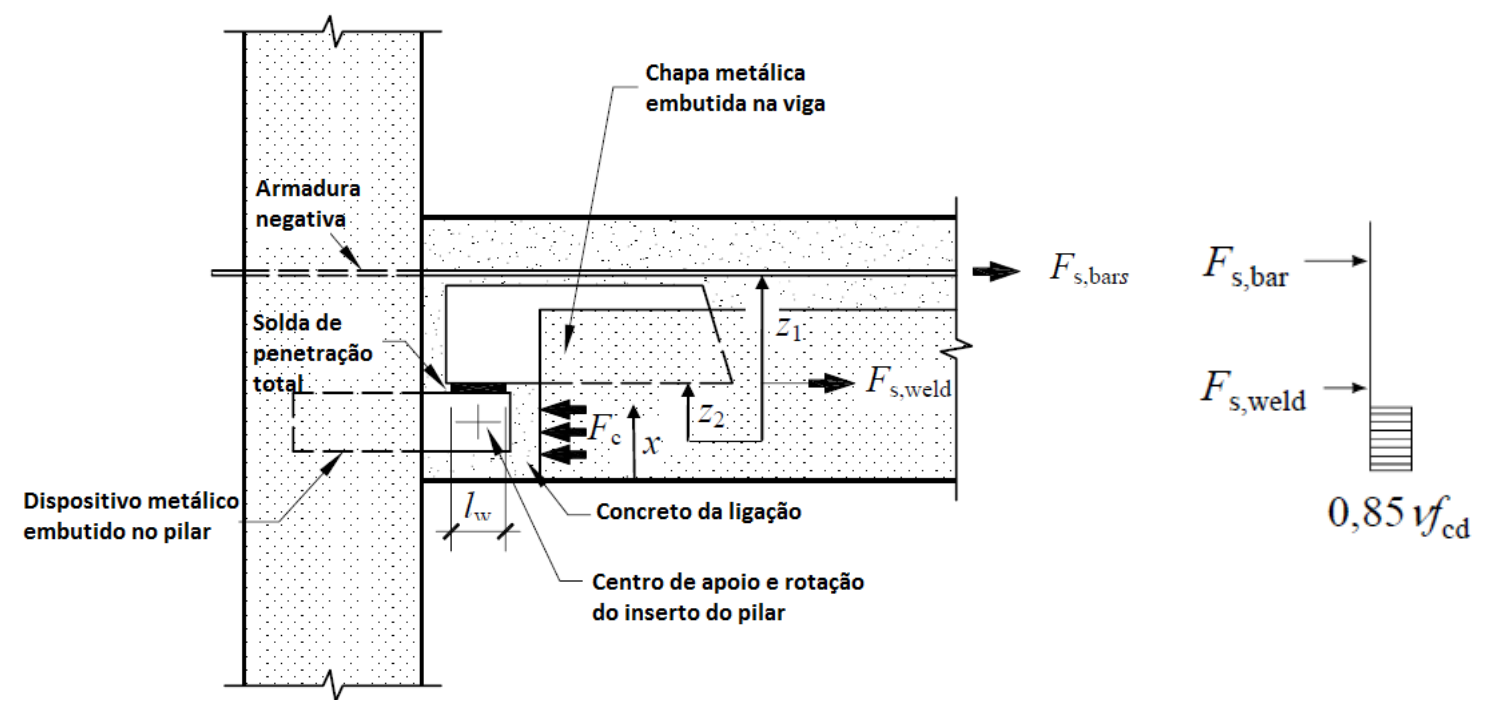

Figura 2.7 - Componentes da ligação e forças atuantes no modelo do CEB-FIP (2008).

A verificação desse modelo de ligação é realizada conforme as equações abaixo considerando o concreto no estádio III:

$$
\begin{aligned}
& F_{c}=0,85 v f_{c d} \cdot b \cdot 0,8 x \\
& F_{s}=f_{w d} l_{w} t_{w}+f_{y d} A_{s}
\end{aligned}
$$

Onde,

$$
\nu=1-\frac{f_{c k}}{250} \quad\left(f_{c k} \text { em MPa }\right)
$$

$f_{w d}=$ resistência de cálculo da solda;

$l_{w}=$ comprimento da solda;

$t_{w}=$ largura efetiva da solda;

$A_{s}=$ área da armadura negativa;

$f_{c d}=$ resistência de cálculo à compressão do concreto;

$x=$ posição da linha neutra.

Por equilíbrio,

$$
F_{c}=F_{s}
$$

Assim, a posição da linha neutra " $x$ " pode ser determinada e, consequentemente, as distâncias $z_{1}$ e $z_{2}$. 
Dessa forma obtém-se o momento resistente da ligação conforme equação abaixo: $M_{R d}=A_{s} f_{y d} \cdot z_{1}+f_{w d} l_{w} t_{w} \cdot z_{2}$

DOLAN; STANTON e ANDERSON (1987) estudaram o comportamento dos tipos de ligações mais comuns utilizadas, sendo ligações simples articuladas e ligações resistentes ao momento fletor. O objetivo do estudo foi examinar o desempenho estrutural das ligações quanto à capacidade de carga e deformação, também analisar os custos efetivos e a exequibilidade. Focaram no carregamento gravitacional e lateral para simular situações de vento ou sísmicas. Estudaram oito tipos de ligações resistentes ao momento fletor. A Figura 2.8 apresenta os modelos estudados por DOLAN; STANTON e ANDERSON (1987).

A ligação denominada de BC15 é composta por chapas metálicas soldadas para permitir a continuidade dos momentos positivo e negativo. Para resistir ao momento negativo, na superfície superior da viga, durante a produção, uma chapa metálica é soldada na armadura negativa. É deixada uma chapa de espera no pilar, ancorada por pinos metálicos, conforme Figura 2.2, que na montagem é soldada na chapa deixada na viga. A ligação resistente ao momento positivo é realizada por meio da solda entre as chapas metálicas ancoradas na superfície inferior da viga e no consolo de concreto moldado no pilar. A resistência ao momento positivo dessa ligação é muito próxima da resistência ao momento negativo. Sob a ação de momento negativo a ruptura da ligação ocorreu na região da solda de campo.

No modelo BC16A a ligação positiva é a mesma do modelo BC15 e a ligação negativa foi realizada com a armadura passando através do pilar e na região onde é feito o preenchimento com concreto em campo e em capas de laje por exemplo. Essa ligação apresentou um bom comportamento quanto à resistência ao momento fletor, sendo consideravelmente maior do que a calculada. Apresentou boa ductilidade, porém a medida de tenacidade foi baixa.

Os modelos BC25 e CC1 são com ligações entre segmentos de pilares, não cabendo discorrer sobre elas neste trabalho, pois não faz parte do escopo.

A ligação BC26 é de uma viga pré-moldada em um pilar moldado no local. Nessa ligação são apenas deixadas esperas das armaduras positivas e negativas na viga para serem ancoradas no pilar. Esse tipo de ligação não é usual por ser inviável na maioria dos casos. Nesta situação é necessário usar escoramentos para a viga e equipamento para içá-la, 
aumentando o custo. O comportamento desta ligação é semelhante ao de uma estrutura monolítica.

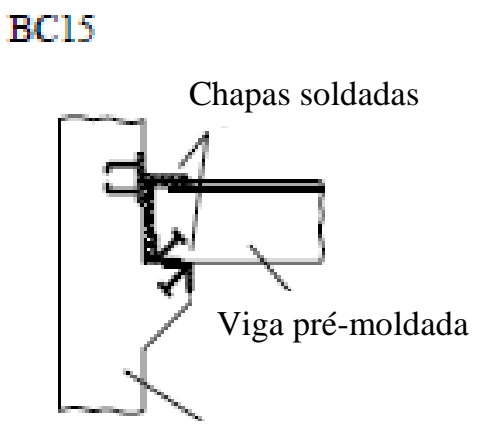

Pilar pré-moldado

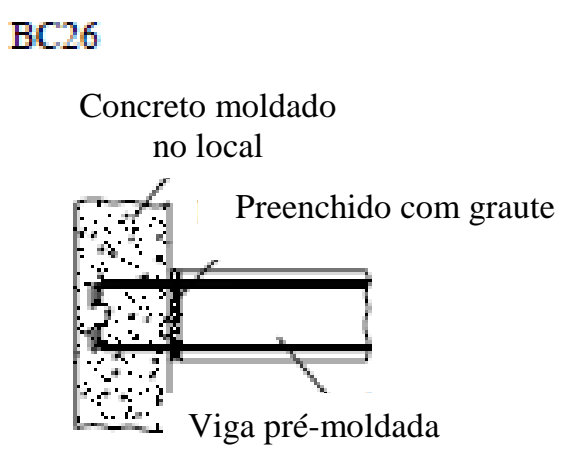

\section{$\mathrm{BC} 27$}

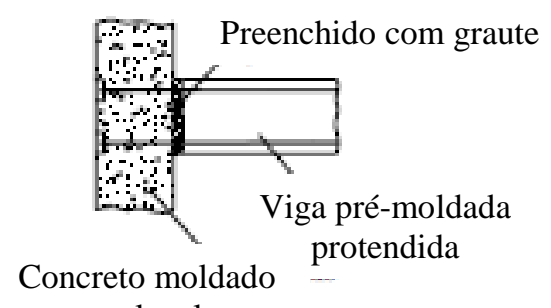
no local
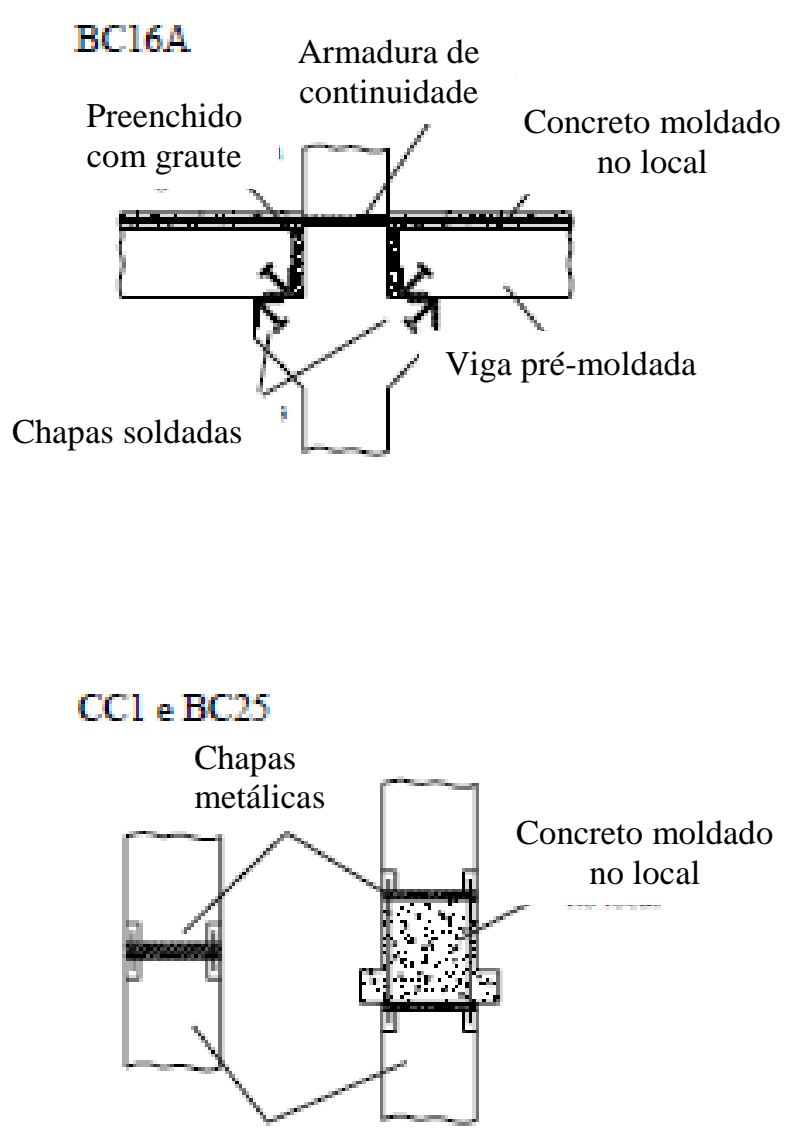

Pilar pré-moldado

\section{BC28 E BC29}

Chumadores grauteados

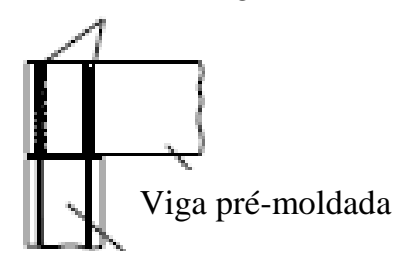

Pilar pré-moldado

Figura 2.8 - Detalhes dos modelos de ligações resistentes ao momento fletor estudados por DOLAN; STANTON e ANDERSON (1987).

A ligação do modelo BC27 é feita através de protensão com pós-tração. As cordoalhas são passadas na viga, nas bordas superior e inferior, e atravessam o pilar sendo ancoradas na face oposta. Esse tipo de ligação apresenta boa resistência e ductilidade. A ligação protendida apresenta uma boa rigidez inicial. 
A ligação do modelo BC28 e BC29 é semi-rígida, feita através de grauteamento na viga. Nesse modelo a viga é ligada no topo do pilar e as barras de espera do pilar são grauteadas na viga. Possui alta deformabilidade e baixa resistência ao momento fletor. Esse tipo de ligação permite a continuidade parcial do momento.

O tipo de ligação do modelo BC99 foi detalhado para resistir integralmente ao momento fletor. Essa ligação consiste em barras "dywidag" rosqueadas nas ancoragens mecânicas na face oposta do pilar. O espaço entre a viga e o pilar deve ser grauteado. A ruína da ligação ocorreu por ruptura da ancoragem mecânica. O que pode ser corrigido com ancoragens mais resistentes. Esse tipo de ligação permite uma fácil e rápida montagem, tornando o sistema viável, porém a perda de ductilidade e resistência devido aos conectores torna a ligação indesejável para ser usada em estruturas resistentes ao momento fletor.

Outro interessante estudo realizado sobre ligações viga pilar resistentes ao momento fletor foi o de EL-GHAZALY e AL-ZAMEL (1991). Listaram as condições que devem ser observadas no detalhamento das ligações em concreto pré-moldado:

a) A execução das ligações deve ser simples e tecnicamente possível;

b) Devem ser considerados espaços suficientes que permitam a montagem;

c) As ligações devem ser dimensionadas para resistirem à corrosão e necessitar de pouca ou nenhuma manutenção;

d) As ligações devem possuir uma tolerância máxima que tornem a construção praticável com relação a estrutura e a arquitetura;

e) Onde nas ligações for necessário realizar concretagem em campo, os detalhes devem permitir, quando possível, o auto adensamento do concreto;

f) A ligação deve ser detalhada para minimizar o tempo de utilização de equipamentos para içar o elemento pré-moldado.

Além das observações para o detalhamento das ligações listadas acima por ELGHAZALY e AL-ZAMEL (1991), devem ser satisfeitas as seguintes características de comportamento estrutural:

a) Rigidez: a ligação deve apresentar rigidez semelhante à de uma estrutura monolítica, é inaceitável grandes deformações e aberturas de fissuras da ligação no estado em serviço; 
b) Resistência: o detalhe da ligação deve ser capaz de suportar as forças resultantes da formação de uma rótula plástica na viga;

c) Ductilidade: a ligação dúctil deve ser capaz de se submeter a grandes deformações após o estágio de perda de resistência;

d) Bom comportamento em serviço: a ligação submetida ao carregamento de utilização não deve sofrer fissuração excessiva.

Neste estudo foi analisado o comportamento da ligação apresentada na Figura 2.9.

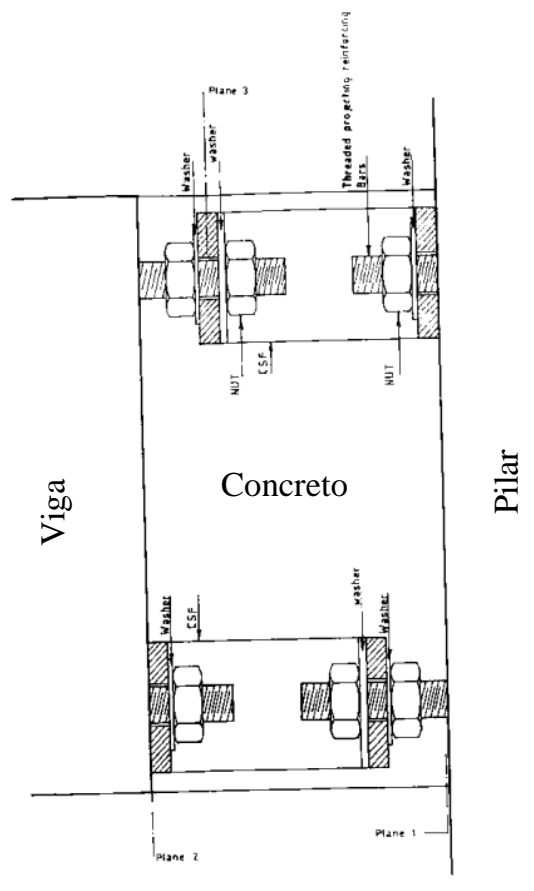

a)

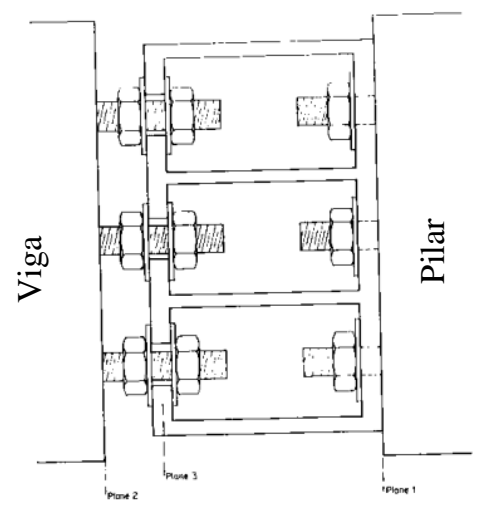

b)

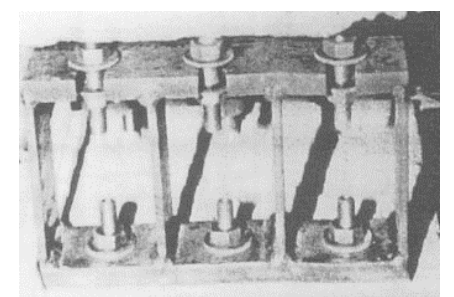

c)

Figura 2.9 - Detalhe do modelo de ligação: a) vista lateral da ligação, b) vista superior da ligação; c) detalhe do dispositivo metálico.

Fonte:EL-GHAZALY e AL-ZAMEL (1991).

A ligação das armaduras da viga e do pilar é realizada por meio de um dispositivo metálico, Figura 2.9 c). O elemento metálico de ligação é constituído de duas chapas, sendo uma faceando a viga e outra junto ao pilar, com enrijecedores transversais às chapas soldados. O dispositivo é parafusado, em uma das chapas, em barras rosqueadas montadas no pilar, enquanto que na outra chapa são deixados vãos para encaixe das barras rosqueadas montadas na viga durante a montagem da estrutura. Existe uma folga entre o dispositivo metálico e a viga, portanto para a fixação são utilizadas porcas e contra porcas. Dessa forma é permitida uma maior tolerância durante a montagem, podendo ser ajustada em campo. Após a montagem da ligação o vão entre a viga e o pilar é concretado. Na região de compressão da 
ligação, a orientação dos vão de encaixe é invertida de modo que o dispositivo é parafusado nas armaduras de compressão da viga, enquanto que os vãos de encaixe são engatados nas barras rosqueadas montadas no pilar, conforme Figura 2.9 a), neste caso esperando a solicitação ao momento negativo, portanto a região de compressão é a inferior.

EL-GHAZALY e AL-ZAMEL (1991) ensaiaram doze modelos para avaliar o comportamento da ligação à flexão e ao cisalhamento e um modelo piloto foi montado anteriormente para verificar a exequibilidade do modelo. Chegaram à conclusão que o modelo de ligação apresenta facilidade de montagem, flexibilidade das tolerâncias e bom comportamento em serviço. A ligação possui boa capacidade de absorver os momentos fletores e as tensões de cisalhamento conforme dimensionamento prévio. As aberturas de fissura ocorridas durante o estado em serviço foram aceitáveis.

O modelo de ligação de EL-GHAZALY e AL-ZAMEL (1991) não foi ensaiado com carregamento cíclico, não podendo afirmar o comportamento para este tipo de solicitação.

EL-GHAZALY e AL-ZAMEL (1991) propõem alterar o modelo de ligação enrijecendo os dispositivos metálicos com mísulas, conforme Figura 2.10 a) e acrescentando estribos e armaduras de costura na região da ligação para reduzir a fissuração e aumentar o confinamento do concreto, conforme Figura 2.10 b).

a)

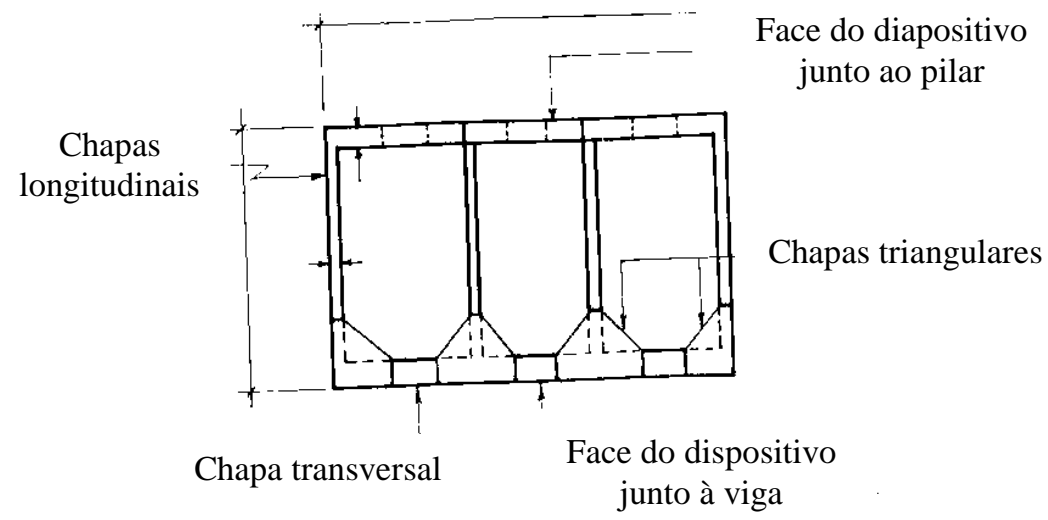


b)

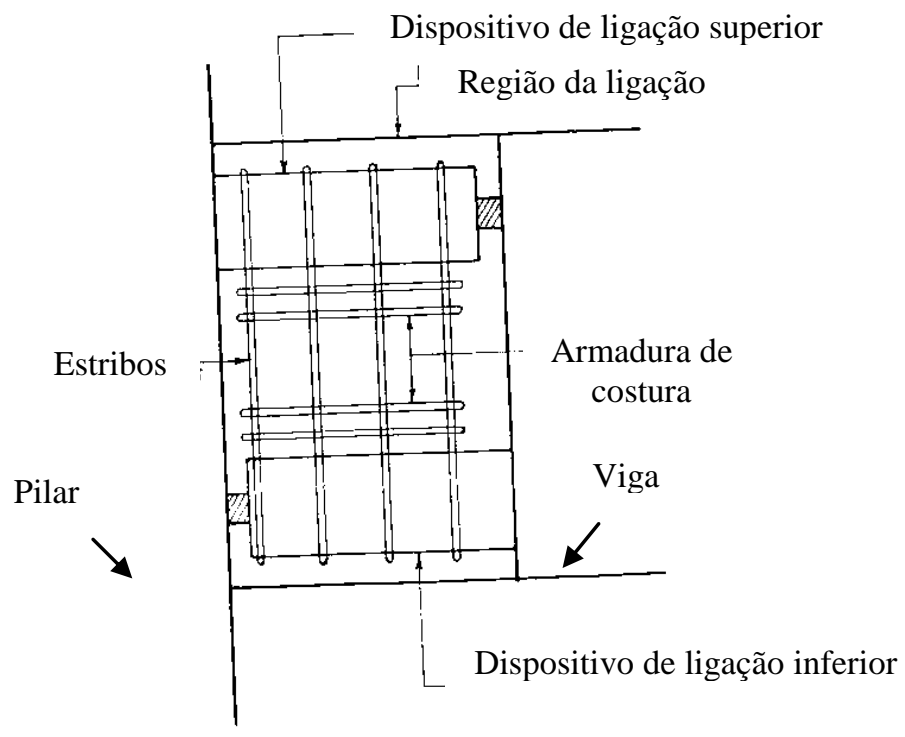

Figura 2.10 - Recomendações: a) dispositivo metálico com mísulas, b) estribos e armadura de costura. Fonte:EL-GHAZALY e AL-ZAMEL (1991).

ERTAS; OZDEN e OZTURA (2006) realizaram uma pesquisa investigando ligações moldadas no local, mistas com chapas de aço soldadas e com barras protendidas em insertos metálicos, comparando com os resultados de um modelo monolítico. Esses tipos de ligações em concreto pré-moldado foram escolhidos de acordo com os sistemas mais utilizados nas práticas construtivas da América do Norte, Europa e Japão. Os resultados dos ensaios foram comparados com relação à resistência da ligação, a rigidez e a tenacidade. As Figuras 2.11 a 2.12 abaixo mostram os modelos de ligações ensaiadas por ERTAS; OZDEN e OZTURAN, (2006).
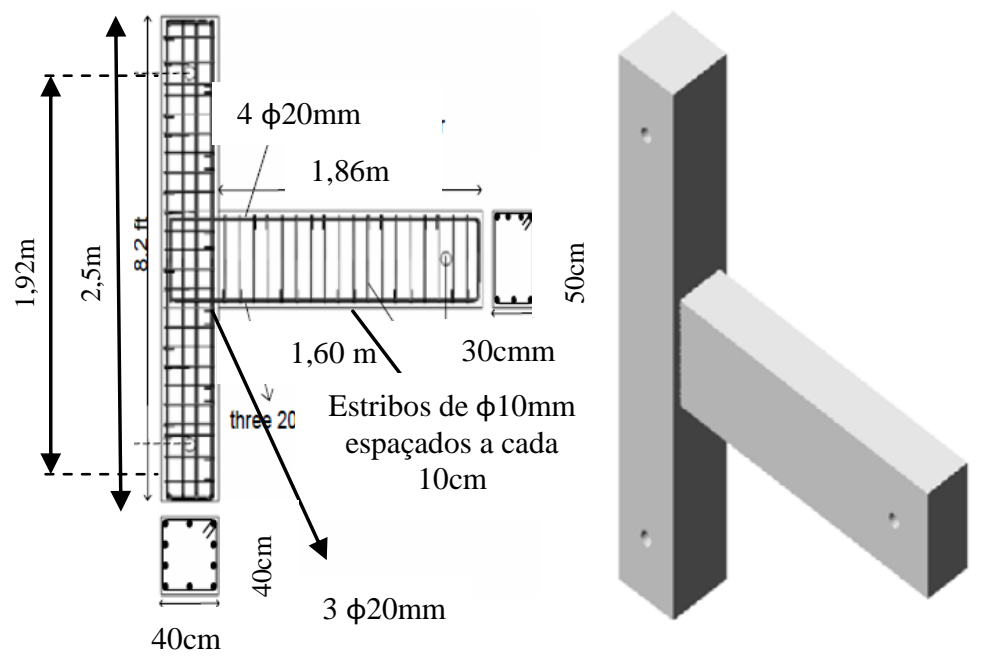

Figura 2.11 - Detalhe do modelo monolítico, ERTAS; OZDEN e OZTURAN (2006). 

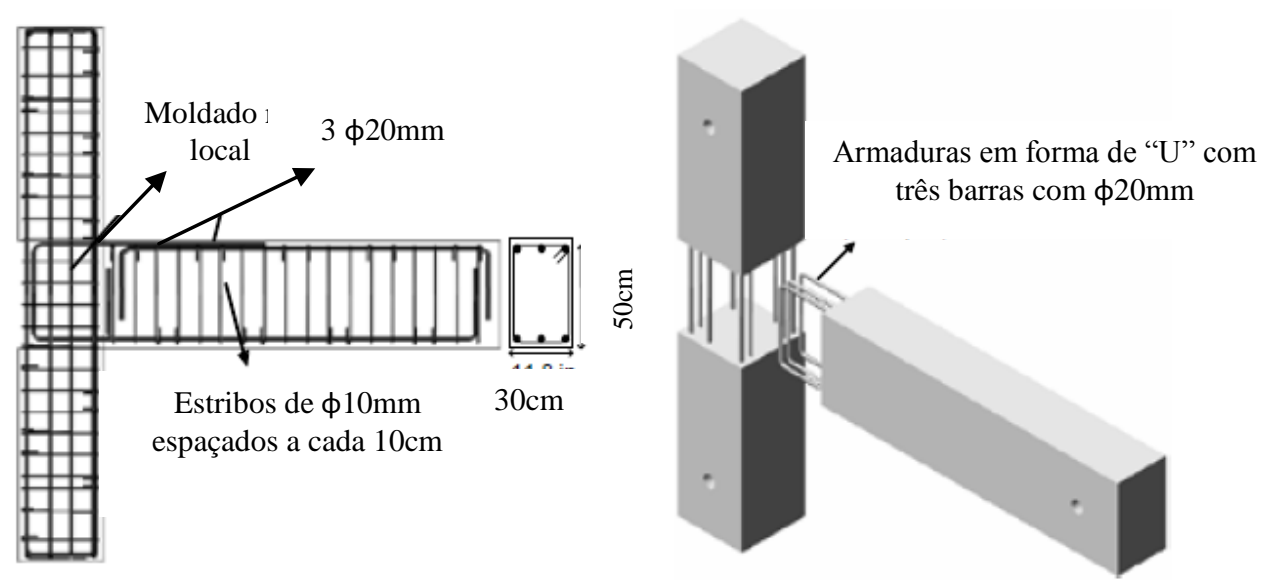

Figura 2.12 - Detalhe do modelo com a ligação no pilar moldada no local, ERTAS; OZDEN e OZTURAN (2006).

No modelo da Figura 2.13 existe uma interrupção de concreto no trecho do pilar, onde é executada a ligação. As armaduras deixadas de espera na viga, componentes da ligação, são em forma de "U" ou laço, sendo a região da dobra conectada ao pilar e deixado um comprimento de ancoragem embutido na viga. Na montagem as barras de espera da viga são encaixadas no vazio deixado no pilar e posteriormente à execução da forma, a ligação foi preenchida com concreto com $0,5 \%$ de fibras de aço. Devido à forma de ligação não foi possível usar estribos fechados no pilar, foram instalados estribos abertos em forma de "U".
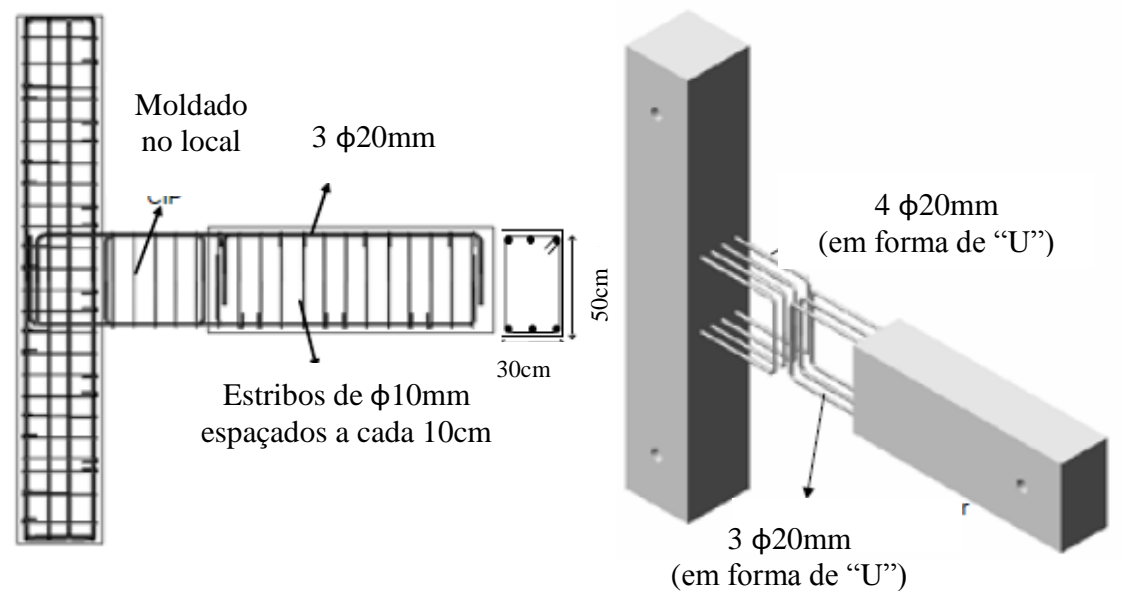

Figura 2.13 - Detalhe do modelo com a ligação na viga moldada no local, ERTAS; OZDEN e OZTURAN (2006).

O modelo da Figura 2.14 bastante semelhante ao da Figura 2.6, diferindo apenas na posição da ligação. Neste modelo a ligação é feita na viga ao invés do pilar. Neste caso são deixadas armaduras de espera na viga e no pilar em forma de "U" que na montagem ficam 
traspassadas, posteriormente é montada a forma e a ligação é preenchida com concreto com fibras de aço.
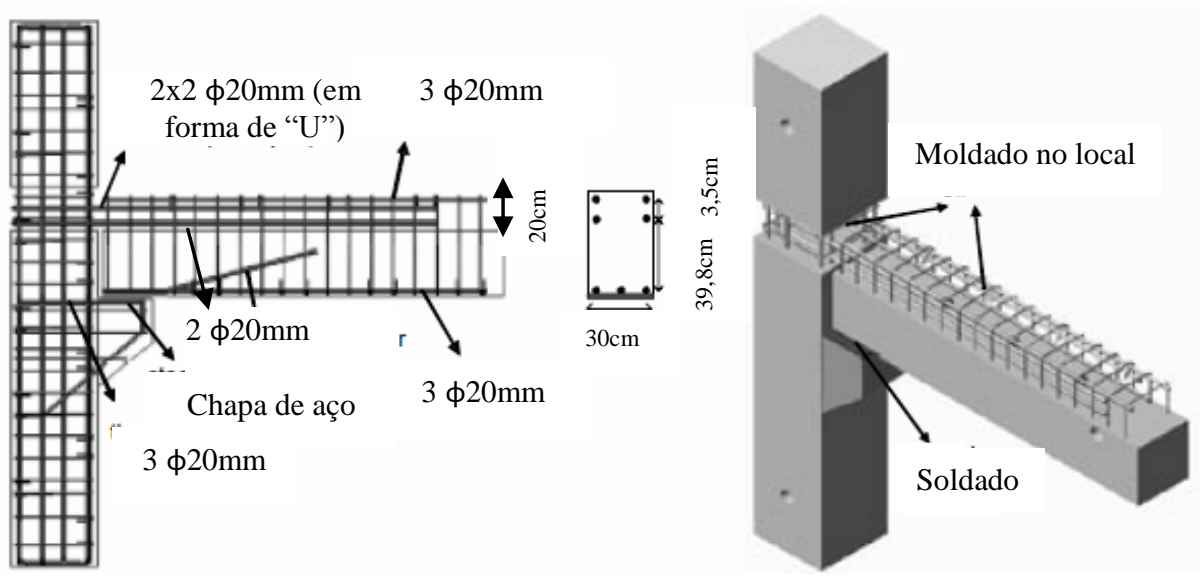

Figura 2.14 - Detalhe do modelo com a ligação mista usando chapas metálicas soldadas e consolo de concreto no pilar, ERTAS; OZDEN e OZTURAN (2006).

Na ligação da Figura 2.15 a condição de continuidade ao momento fletor é adquirida através de solda das barras da armadura positiva da viga em uma chapa metálica ancorada no consolo do pilar, e por barras dobradas em forma de laço, passando pelo espaço deixado no pilar para ancoragem, posteriormente esse espaço é preenchido na concretagem.
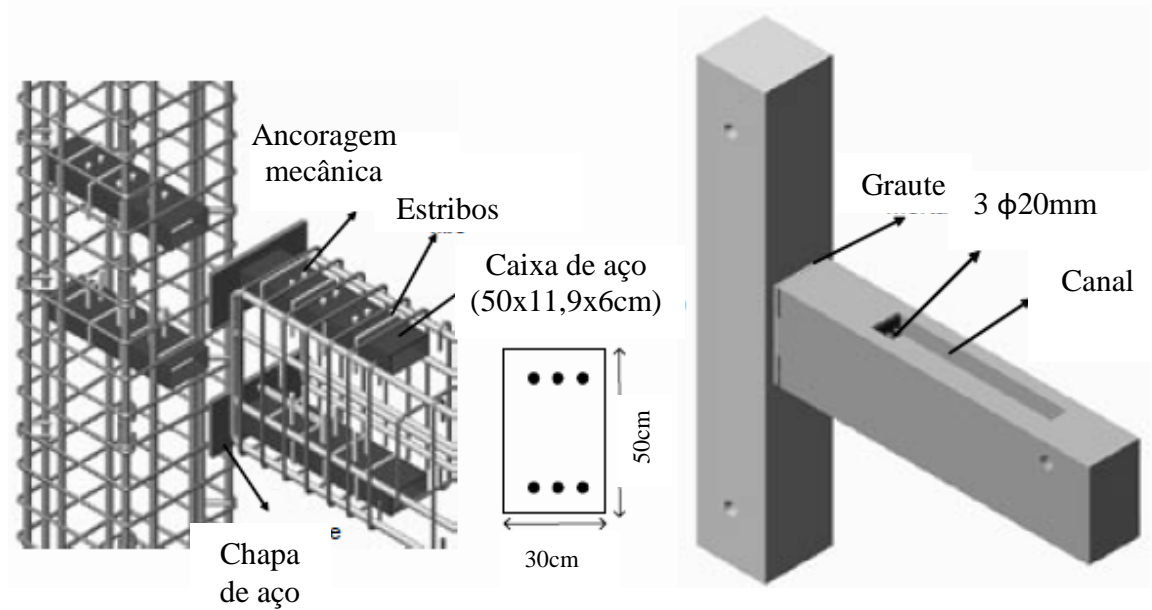

Figura 2.15 - Detalhe do modelo com a ligação protendida, ERTAS; OZDEN e OZTURAN (2006).

O objetivo da ligação da Figura 2.15 é minimizar o trabalho de campo durante a montagem. Nesta ligação são usadas caixas retangulares em aço que permitem maior tolerância dimensional dos elementos pré-moldados, e mais espaço para as barras que passam pelos insertos.Esse tipo de ligação é mais indicado para baixos níveis de foça cortante, como por exemplo, com elementos pré-moldados de laje dispostos paralelamente ao eixo da viga. 
Neste modelo existe um canal na borda superior e inferior da viga para permitir a instalação das barras resistentes aos momentos negativos e positivos durante o processo de montagem. São instaladas na viga e no pilar, atravessando este, caixas de aço retangulares por onde as barras da ligação são passadas. Na região do inserto na viga são instaladas uma taxa maior de estribos para confinamento. São soldadas nos insertosda viga chapas metálicas para facilitar a montagem, tendo como objetivo coincidir os eixos dos dispositivos metálicos da viga com os do pilar.Essas chapas metálicas também são ligadas entre elas por duas barras soldadas.O vão existente entre a viga e o pilar é grauteado.Barras de aço rosqueadas com ancoragem mecânica são passadas através dos dispositivos metálicos embutidos na viga e no pilar utilizando os canais deixados borda superior e inferiorda viga.É aplicado um torque para gerar tensões de tração nessas barras e eliminar as folgas e acomodações, caracterizando essa ligação como protendida. Finalmente os canais deixados na viga são preenchidos com graute.

No primeiro ensaio desta ligação, os dispositivos metálicos embutidos na viga foram soldados nos estribos. Durante o teste, ocorreu o escorregamento dos insertos, verificando-se falta de ancoragem. Para resolver esse problema, foram soldadas nas superfícies dos insertos barras metálicas como pinos para evitar o escorregamento.

Nos ensaios de ERTAS; OZDEN e OZTURAN (2006) foram aplicados carregamentos cíclicos reversíveis, avaliando as resistências aos momentos positivo e negativo das ligações. O carregamento foi realizado lateralmente conforme esquema da Figura 2.16.

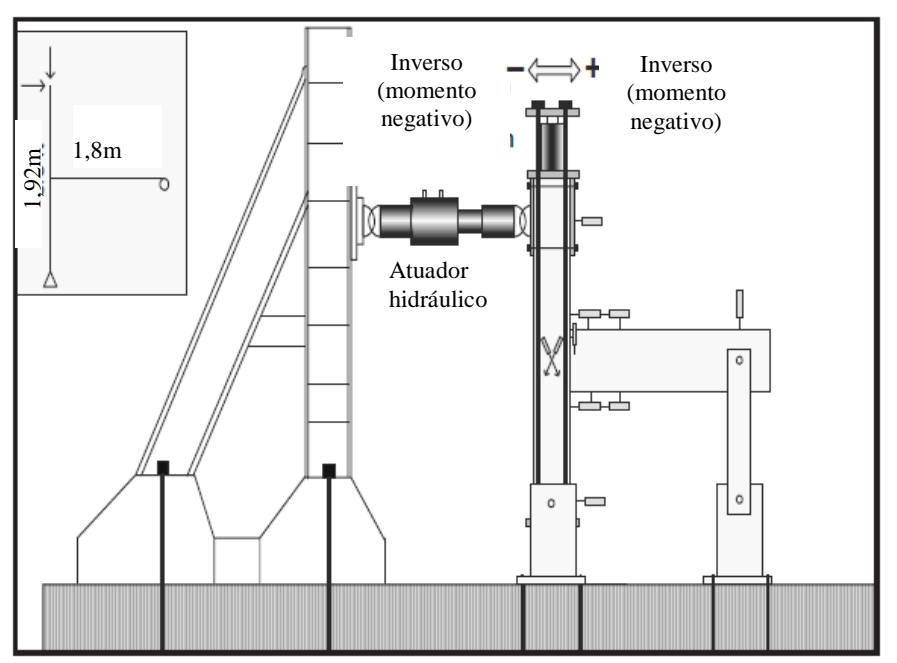

Figura 2.16 - Esquema de carregamento lateral dos modelos de ERTAS; OZDEN e OZTURAN (2006). 
Os gráficos das Figura 2.17 a), b), c), d), e) e f) representam os resultados dos modelos monolítico, da ligação no pilar moldada no local, da ligação na viga moldada no local, da ligação mista, da ligação protendida e da ligação protendida modificada, respectivamente.

ERTAS; OZDEN e OZTURAN (2006) chegaram as seguintes conclusões:

a) $\mathrm{O}$ modelo com ligação protendida apresentou melhor desempenho quanto à resistência, ductilidade e tenacidade, além da facilidade e velocidade de montagem.

b) O comportamento da curva de histerese dos modelos de ligação moldado no local, no pilar e na viga, e da ligação protendida foram próximos do modelo monolítico. $\mathrm{O}$ modelo com a ligação mista apresentou um desempenho inferior comparado com os outros tipos de ligação.

c) As ligações apresentadas atingiram a capacidade última calculada quanto ao momento fletor.

d) Todas as ligações ensaiadas apresentaram ductilidade suficiente para carregamentos sísmicos, exceto do modelo com ligação mista. A solda excessiva pode afetar as propriedades mecânicas do aço, e acredita-se ser a causa do desempenho inferior.

e) Para taxas equivalentes de tenacidade, as ligações dos modelos em concreto pré-moldado são similares ou melhores que no sistema monolítico.

f) Efeitos de punção e deterioração excessiva nas ancoragens não foram observados nos modelos de ligação moldados no local devido à utilização do concreto com fibras e da armadura em laço.

g) No modelo com a ligação protendida, existe um risco de escorregamento da caixa metálica em relação ao concreto, no detalhamento dessa ligação devem ser especificadas barras de aço soldada na caixa metálica comopinos para garantir a ancoragem do inserto.

h) Durante a montagem da estrutura a ligação moldada no local necessita da execução de formas para o concreto, isso aumenta o tempo e o custo da obra. Além disso, a solda da ligação deve possuir um rigoroso controle de qualidade. Em contrapartida, a montagem da ligação parafusada é relativamente rápida. 


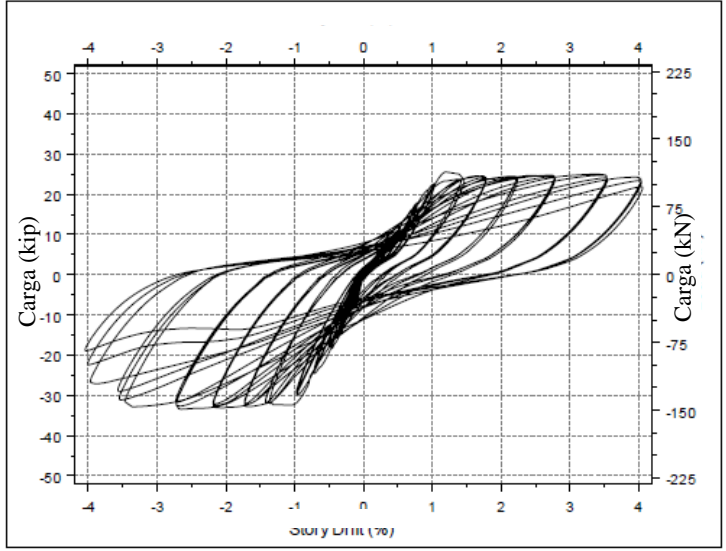

a)

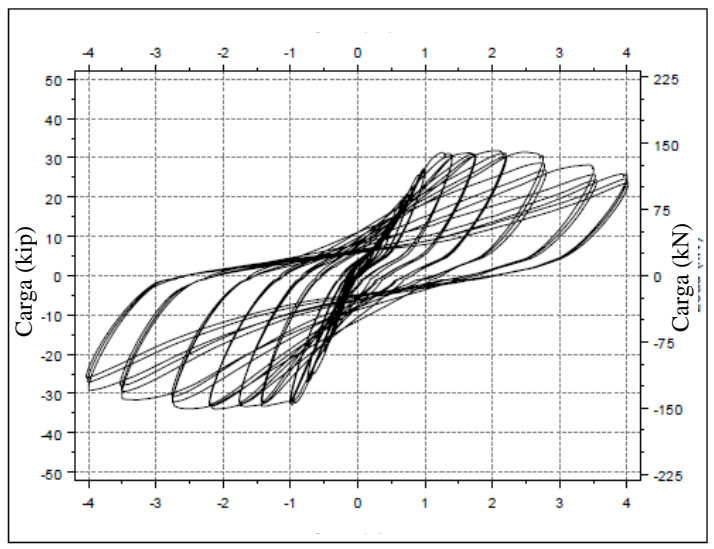

c)

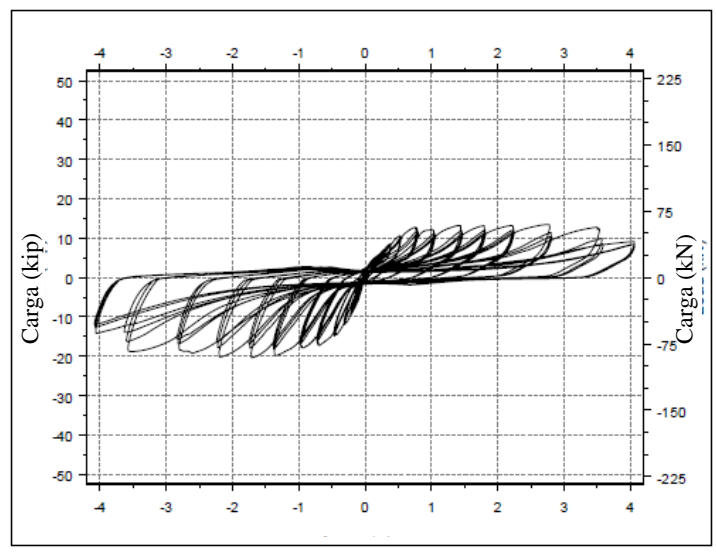

e)

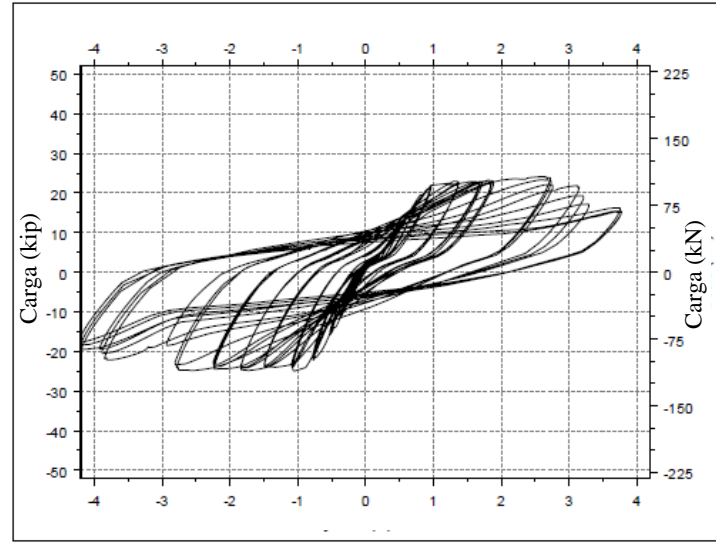

b)

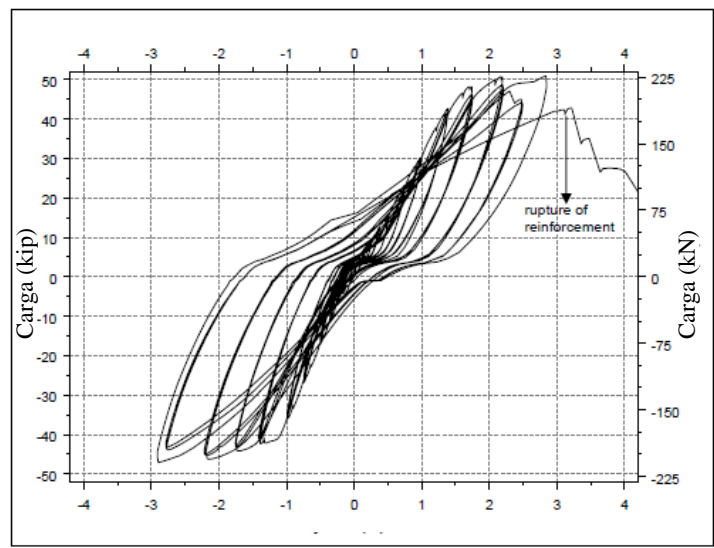

d)

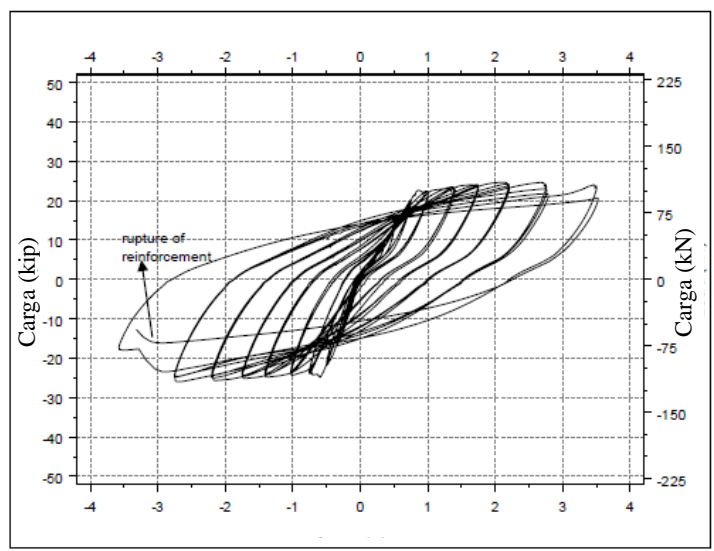

f)

Figura 2.17 - Resultados dos ensaios de ERTAS; OZDEN e OZTURAN (2006): a) modelo monolítico, b) modelo da ligação no pilar moldada no local, c) modelo da ligação na viga moldada no local, d) modelo da ligação mista, e) modelo da ligação protendida, f) modelo da ligação protendida modificada. 
KULKARNI; LI e YIP (2008) analisaram um modelo numérico de ligação viga pilar mista entre aço e concreto com carregamento cíclico. O modelo foi validado pelos resultados experimentais dos ensaios realizados na Universidade de Tecnologia de Nanyang em Cingapura.Este modelo de ligação utiliza seções metálicas para facilitar a conexão entre os elementos pré-moldados. Neste estudo foram analisados um modelo monolítico e três modelos com ligações mistas entre aço e concreto. Um dos modelos de ligação viga pilar está apresentado na Figura 2.18.

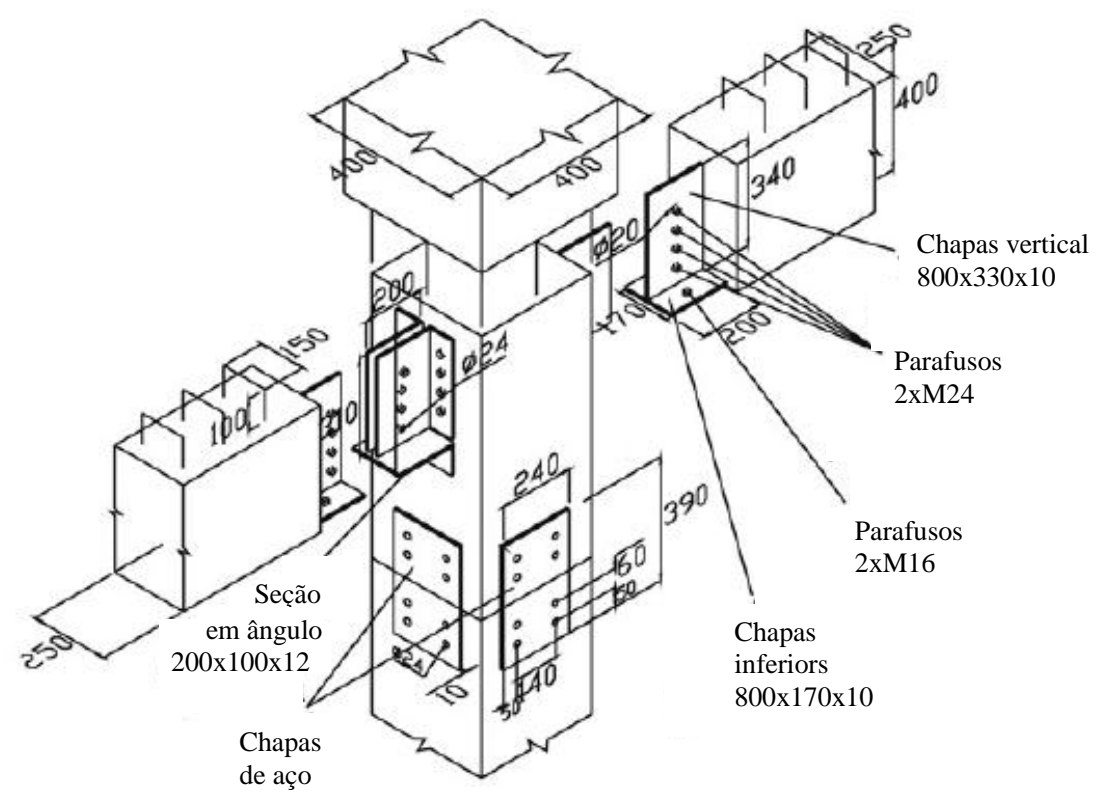

Figura 2.18 - Modelo de ligação viga pilar estudado por KULKARNI; LI e YIP (2008).

No modelo proposto acima ligação viga pilar é realizada por meio de chapas metálicas que são parafusadas com parafusos de alta resistência para haver atrito entre as chapas.

KULKARNI; LI e YIP (2008) chegaram à conclusão que houve boa correlação entre os resultados experimentais e numéricos, as curvas de histerese e o panorama de fissuração foram muito próximos, os modos de ruptura e a ductilidade da ligação também foram semelhantes. A Figura 2.19 a) e b) apresenta as curvas de histerese comparando os resultados experimentais e numéricos dos modelos monolítico e o da Figura 2.19. 


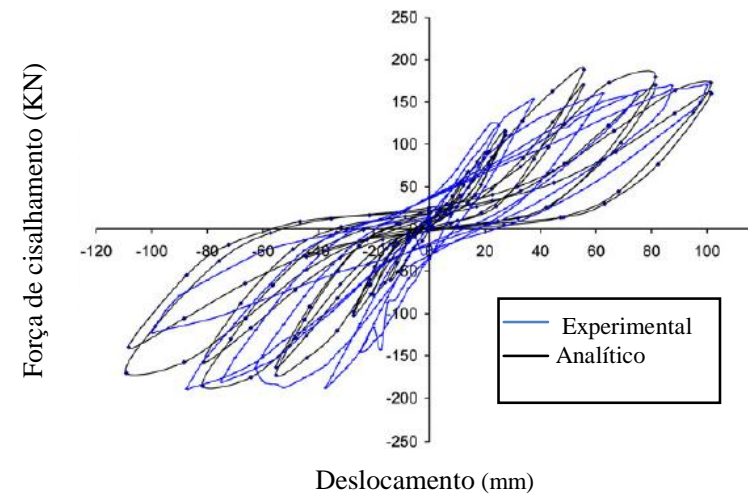

a)

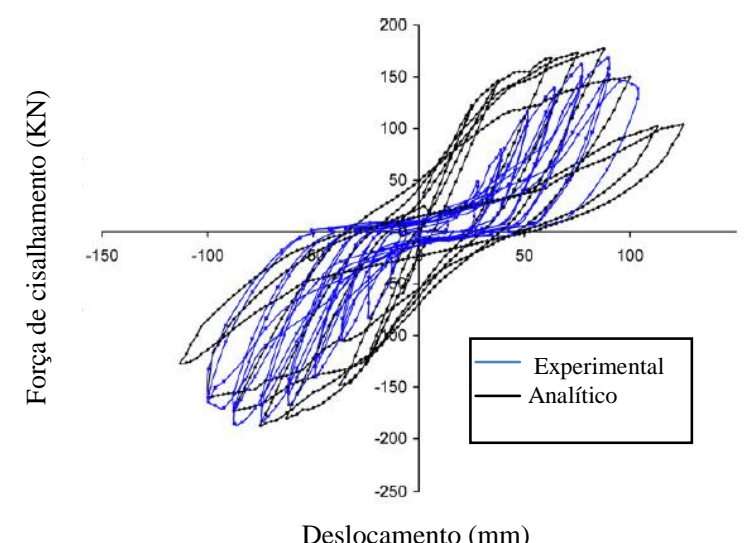

b)

Figura 2.19 - Resultados dos ensaios de KULKARNI; LI e YIP (2008): a) modelo monolítico, b) modelo da Figura 2.18.

Analisaram que a espessura da chapa metálica influencia a energia de dissipação durante o carregamento cíclico. Aumentando a espessura da chapa aumenta-se a resistência da ligação e a tenacidade até certo limite que espessuras maiores não fazem diferença. 


\section{PROGRAMA EXPERIMENTAL}

\subsection{CONSIDERAÇÕES INICIAIS}

O programa experimental descrito nesta seção consiste no estudo de um modelo de ligação viga-pilar em concreto pré-moldado. O modelo foi construído na forma cruciforme para ser apoiado pelas vigas com a aplicação do carregamento no pilar.

Sobre o modelo foram aplicados carregamentos alternados, cíclicos, de curta duração de forma que na ligação atuem momentos fletores positivos e negativos.

A seguir estão apresentados os tópicos referentes ao processo de construção do modelo pré-moldado até a realização do ensaio.

\subsection{PROJETO DA LIGAÇÃO}

As características e dimensões do modelo ensaiado estão apresentadas na Figura 3.1. 


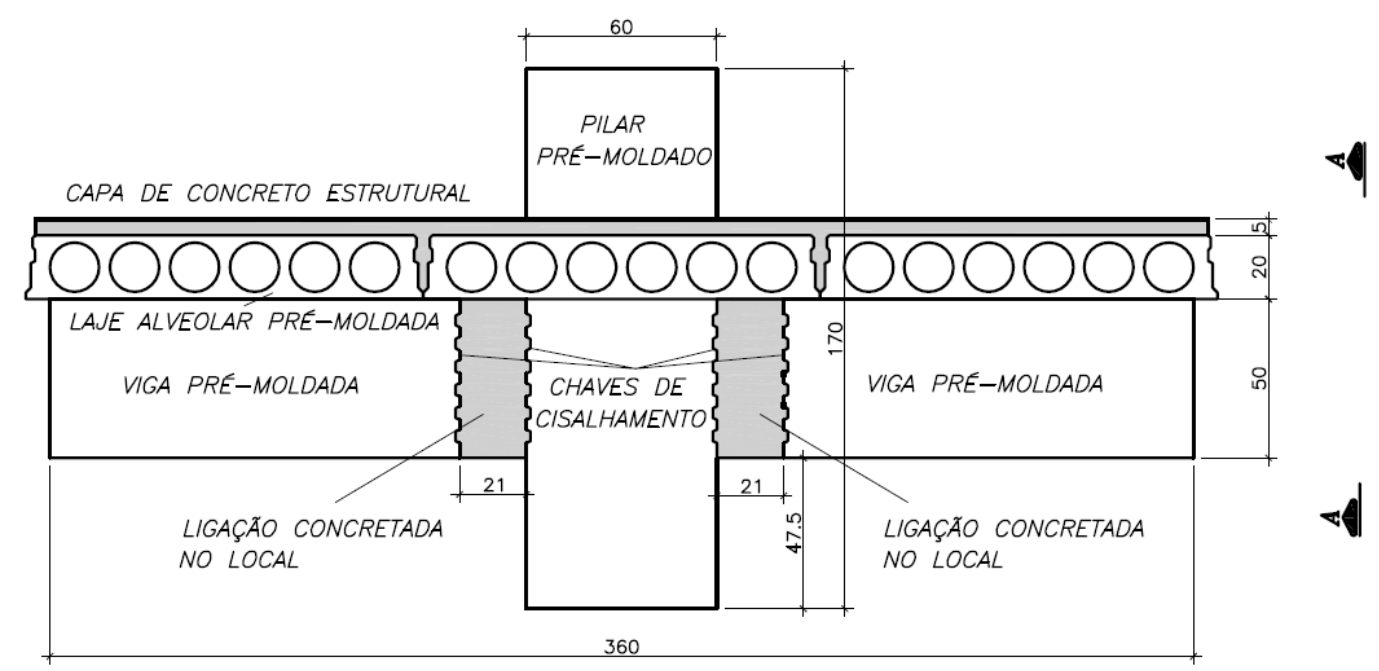

VISTA $A A$

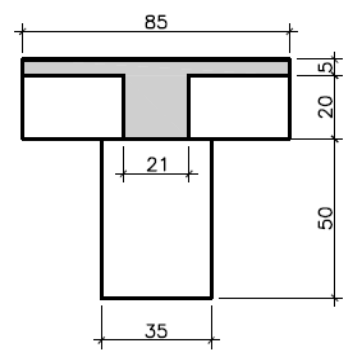

Figura 3.1 - Dimensões do modelo ensaiado.

As características geométricas adotadas para o modelo ensaiado foram adaptadas do projeto do modelo monolítico realizado para a pesquisa de OLIVEIRA JÚNIOR (2009)para serem similares. No modelo objeto deste estudo, optou-se por acrescentar laje alveolar em sua composição, assim as vigas apresentaram seção transversal em " $T$ ".

\subsubsection{Definição da ligação}

Optou-se por adotar um perfil metálico embutido no pilar em seção transversal em forma de "U" formado por uma chapa dobrada. Este perfil possui a função de consolo para a viga na fase de montagem. Na viga foi embutido um dente de perfil metálico com seção transversal tubular retangular de modo que se encaixe no consolo. Num primeiro momento o dente foi fixado no consolo por meio de solda de filete na fase de montagem para garantir a estabilidade lateral da viga. Para que a ligação se comporte mais próxima possível de uma ligação monolítica e haja continuidade de momento fletor, as abas do perfil "U" possuem 
tamanho suficiente para que a ligação soldada entre o consolo e o dente se encontre na altura mais próxima às máximas tensões de tração na seção transversal, quando a ligação for solicitada à flexão. A ligação na parte inferior foi executada por meio de solda das barras da armadura positiva da viga com cantoneiras embutidas no pilar. Os componentes da ligação e a sequencia de montagem estão apresentados na Figura 3.2 e Figura 3.3 respectivamente.

\subsubsection{Especificação do concreto}

Para a confecção das vigas e pilar pré-moldados foi especificado um concreto com resistência característica $f_{c k}=40 \mathrm{MPa}$. Para o concreto moldado no local da ligação foi especificada a mesma resistência dos elementos pré-moldados de 40 MPa. Para a capa da laje moldada no local foi especificada uma resistência característica de $f_{c k}=30 \mathrm{MPa}$.

\subsubsection{Especificação do aço}

As taxas de armaduras do modelo ensaiado foram baseadas no modelo definido no projeto de pesquisa em nível de doutorado de OLIVEIRA JÚNIOR (2009), com adaptações. Procurou-se manter as áreas de armaduras próximas, porém foi necessário alterar as bitolas das barras, pois a quantidade possível de utilizar é limitada. Nas vigas e pilar pré-moldados e na ligação foram utilizados aços CA-50 com diâmetros variando de 6,3 a 25 mm.

Para os perfis metálicos foi utilizado aço ASTM A36 com chapas dobradas de 9,5 $\mathrm{mm}$. Para formar os perfis embutidos nas vigas foram soldados dois perfis "U" dobrados.

Os detalhamentos das armaduras são apresentados na Figura 3.4 à Figura 3.9. 


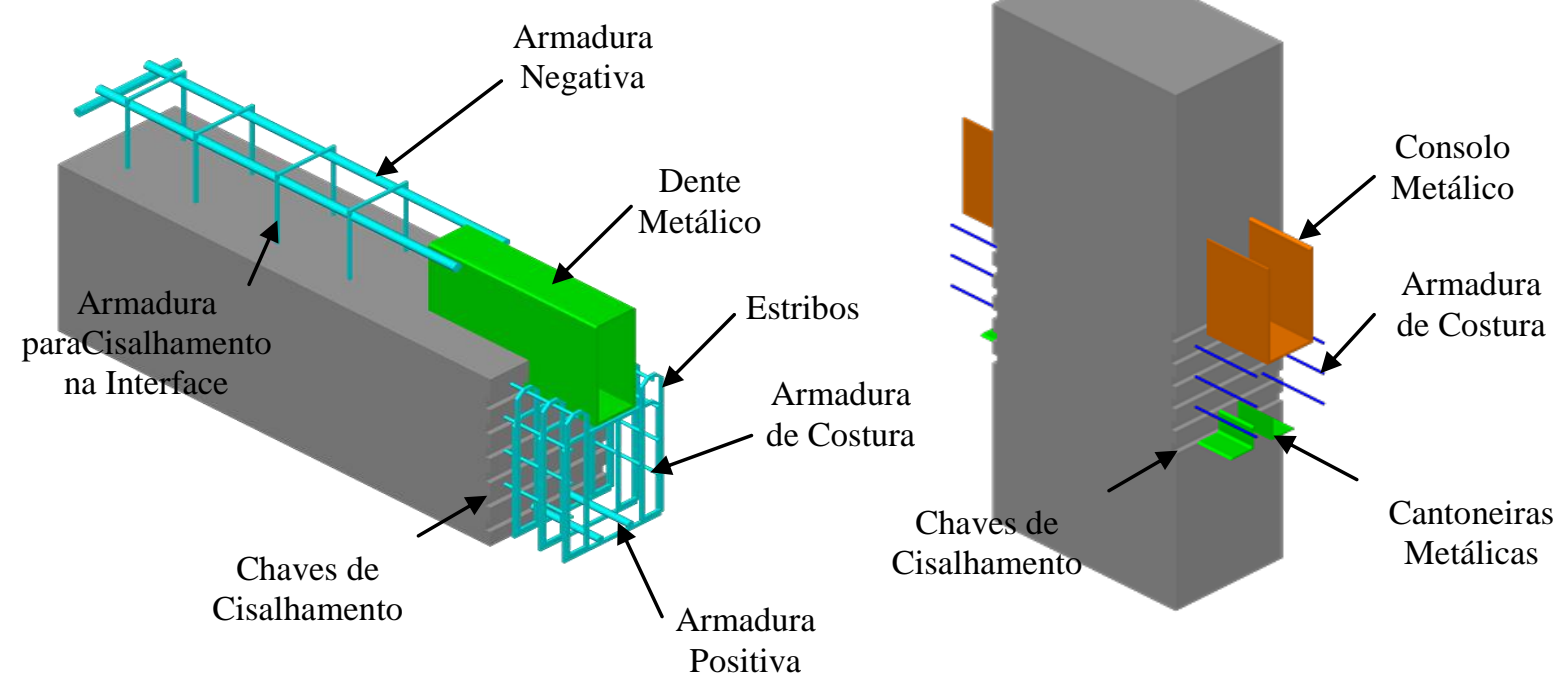

Figura 3.2 - Componentes da ligação.

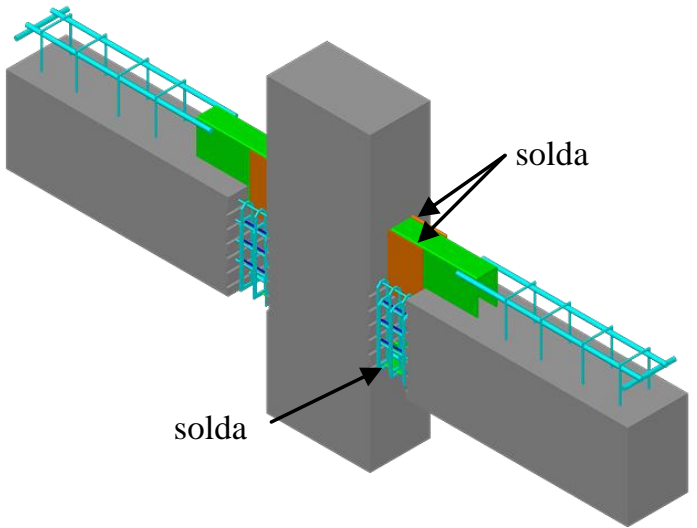

(a) Encaixe do elementos pré-moldados e solda.

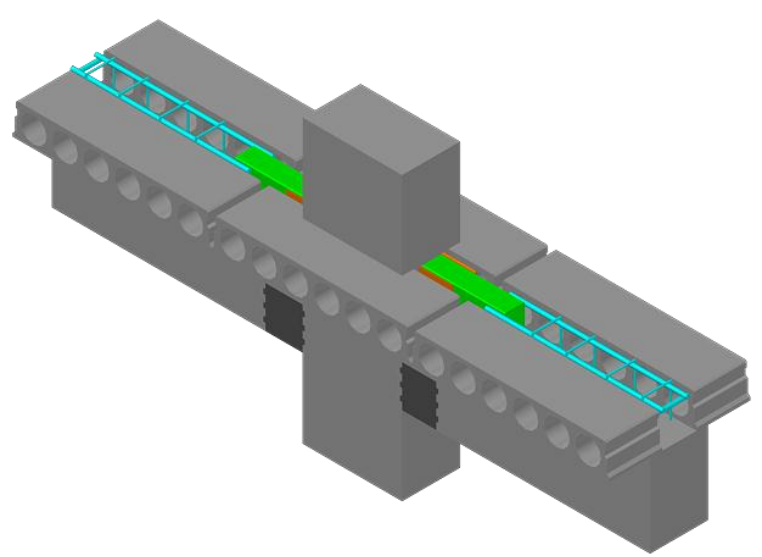

(c) Montagem dos painéis de laje alveolar.

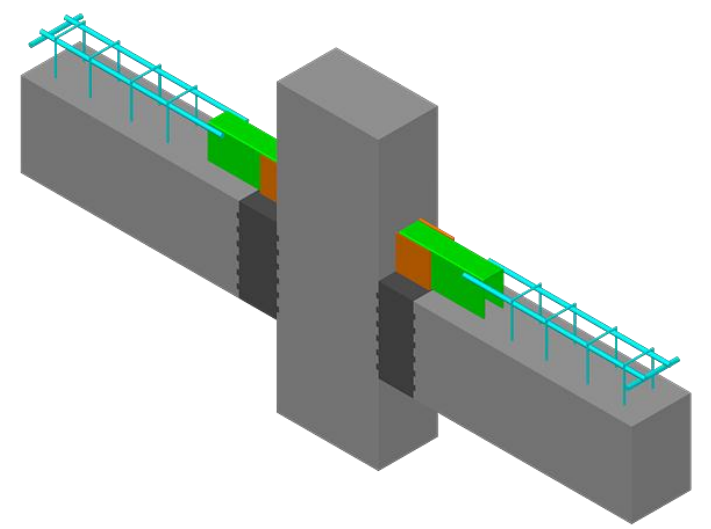

(b) Forma e concretagem da região da ligação.

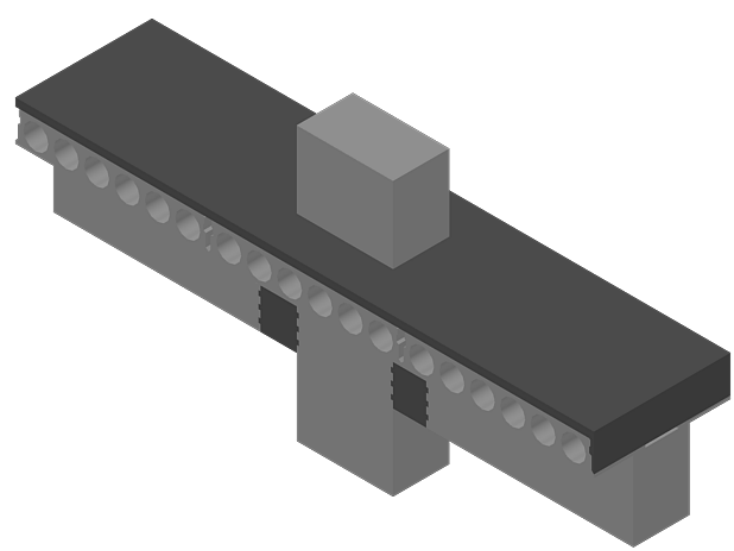

(d) Armação e concretagem da capa da laje.

Figura 3.3 - Sequência de montagem da ligação. 


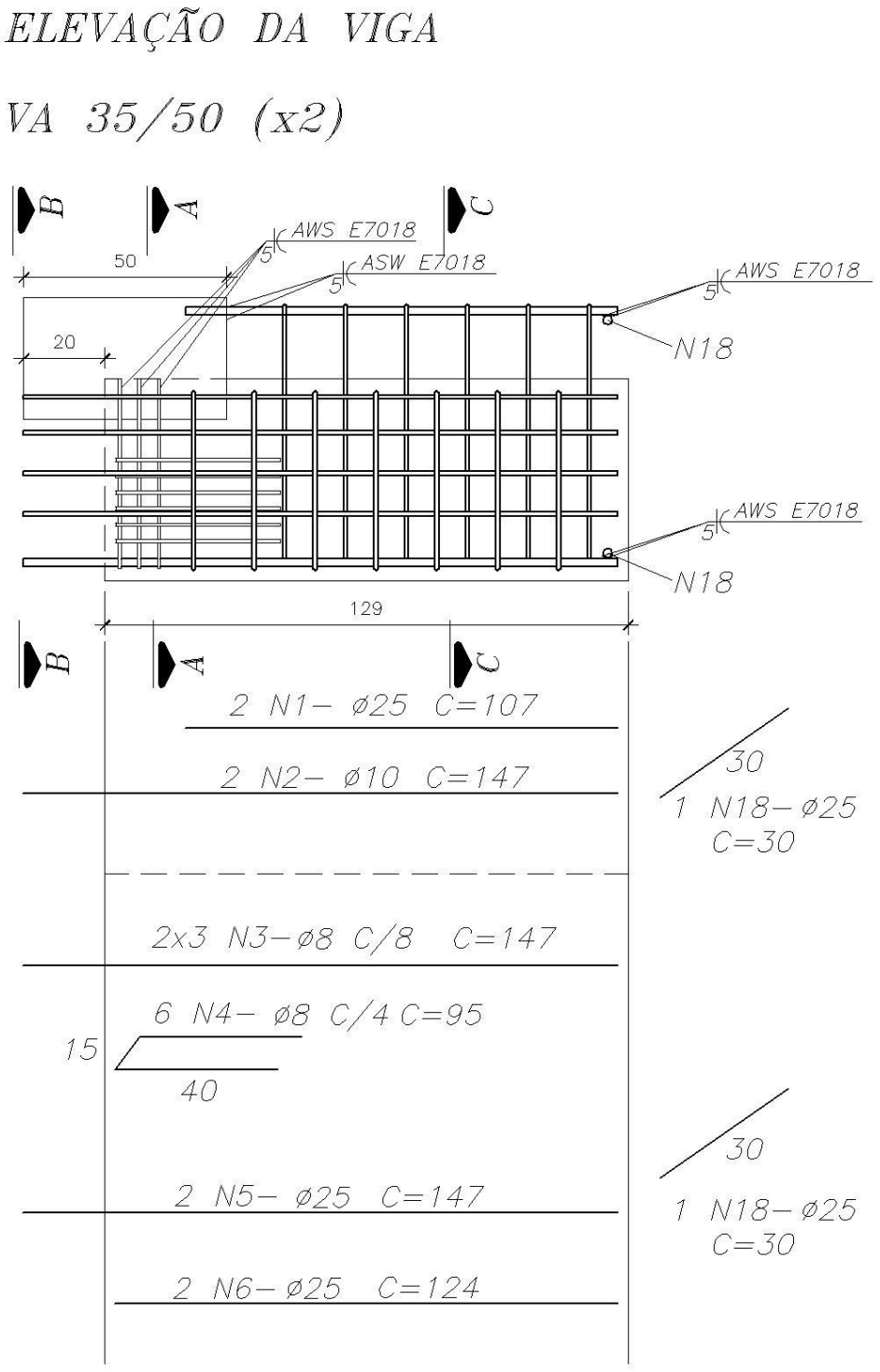

\section{CORTE AA}
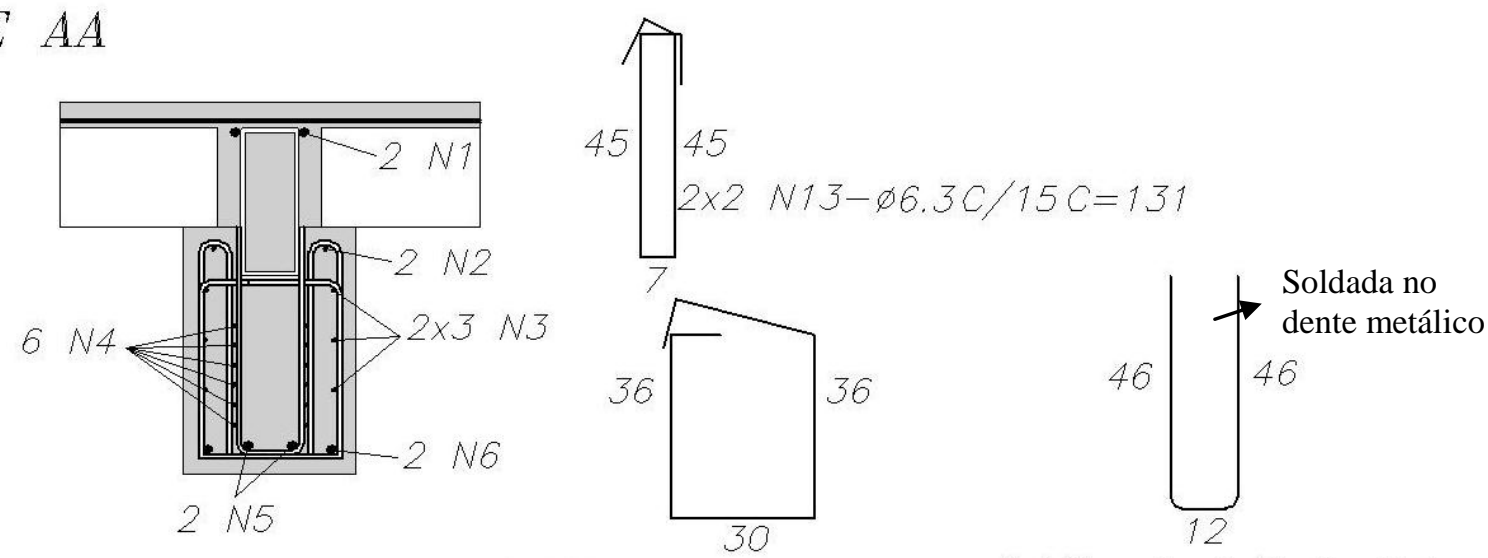

$2 N 7-\not 6.3 C / 15 C=152$

$3 N 8-\varnothing 8$

C) $/ 5 C=104$

Figura 3.4 - Detalhamento das armaduras das vigas e dos elementos ligação (corte AA). 


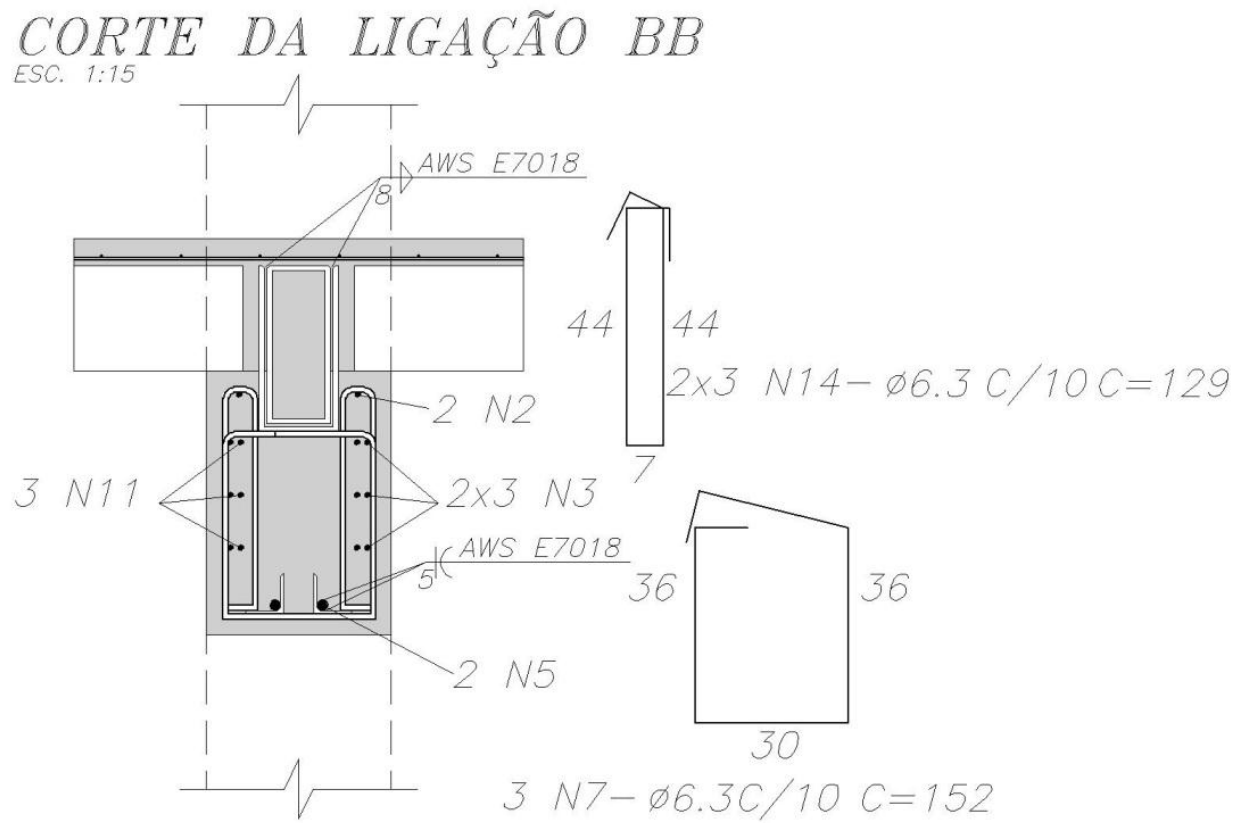

CORTE CC
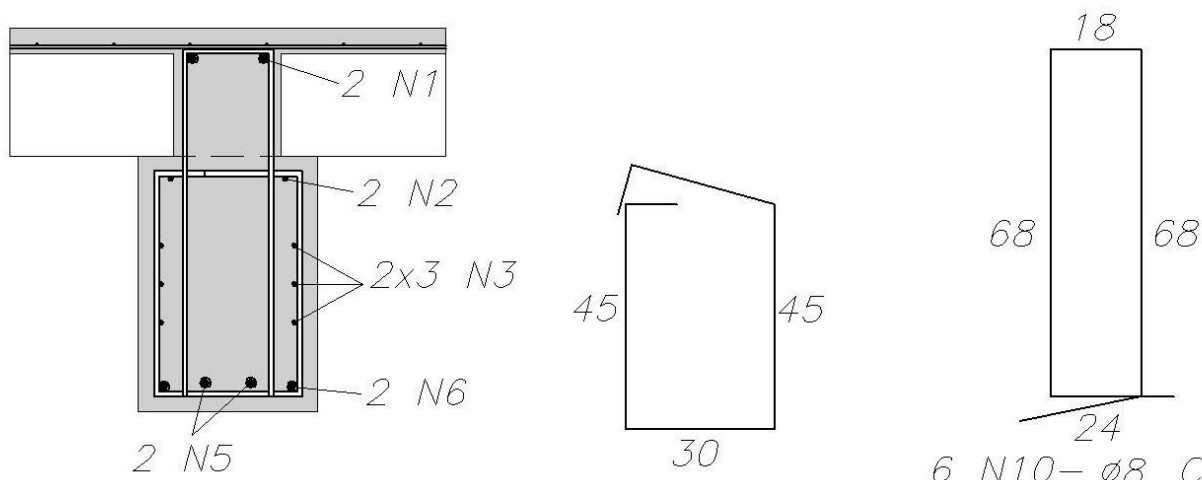

6 N9- $\varnothing 6.3 C / 15 C=170$

$6 \quad N 10-\not 8 \quad C / 15 \quad C=202$

Figura 3.5 - Detalhamento das armaduras das vigas e dos elementos ligação (corte $\mathrm{BB}$ e $\mathrm{CC})$. 
(a)

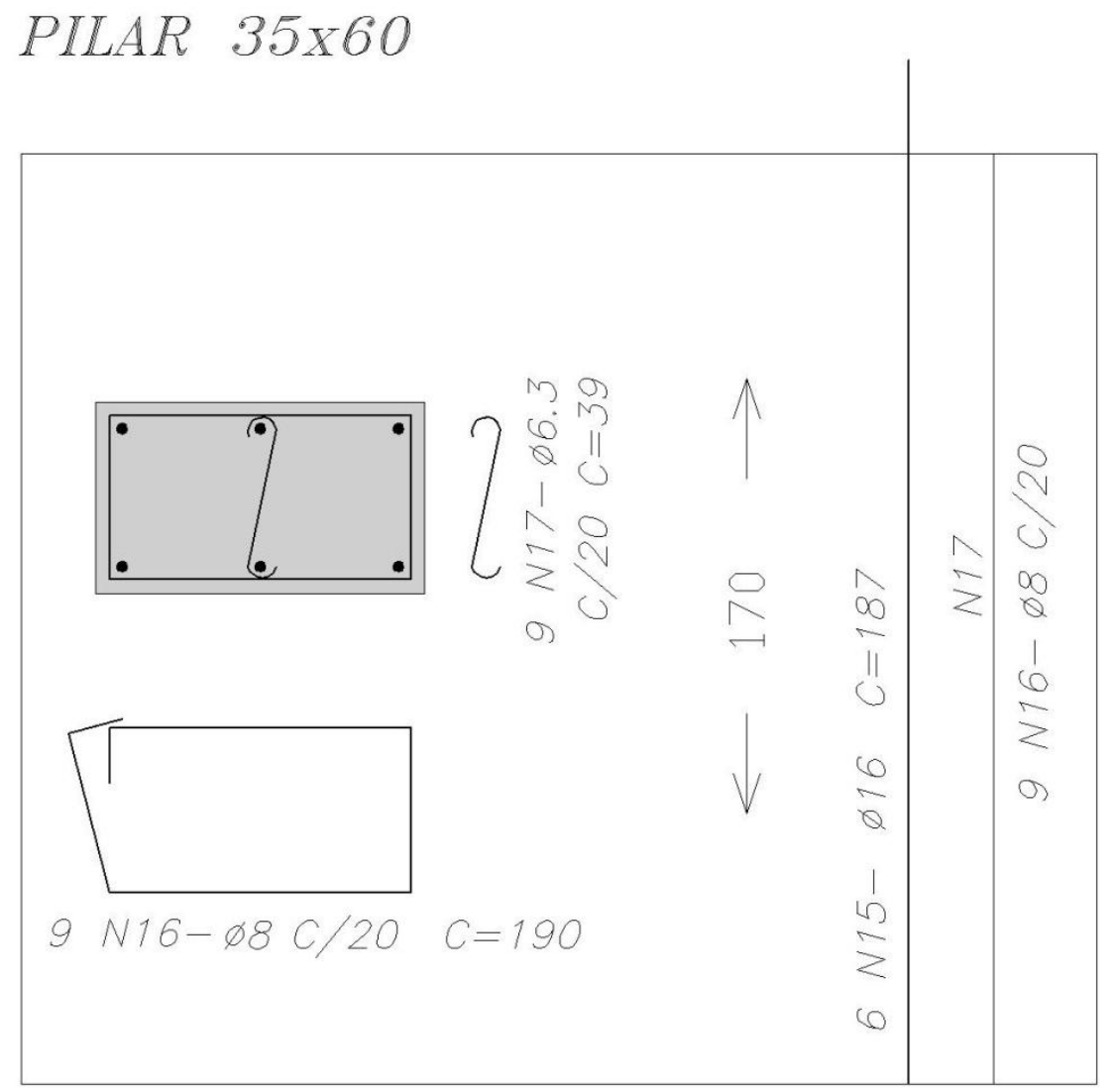

(b)

DETALHE DO PILAR NA REGIT̃O DA LIGAÇÃO

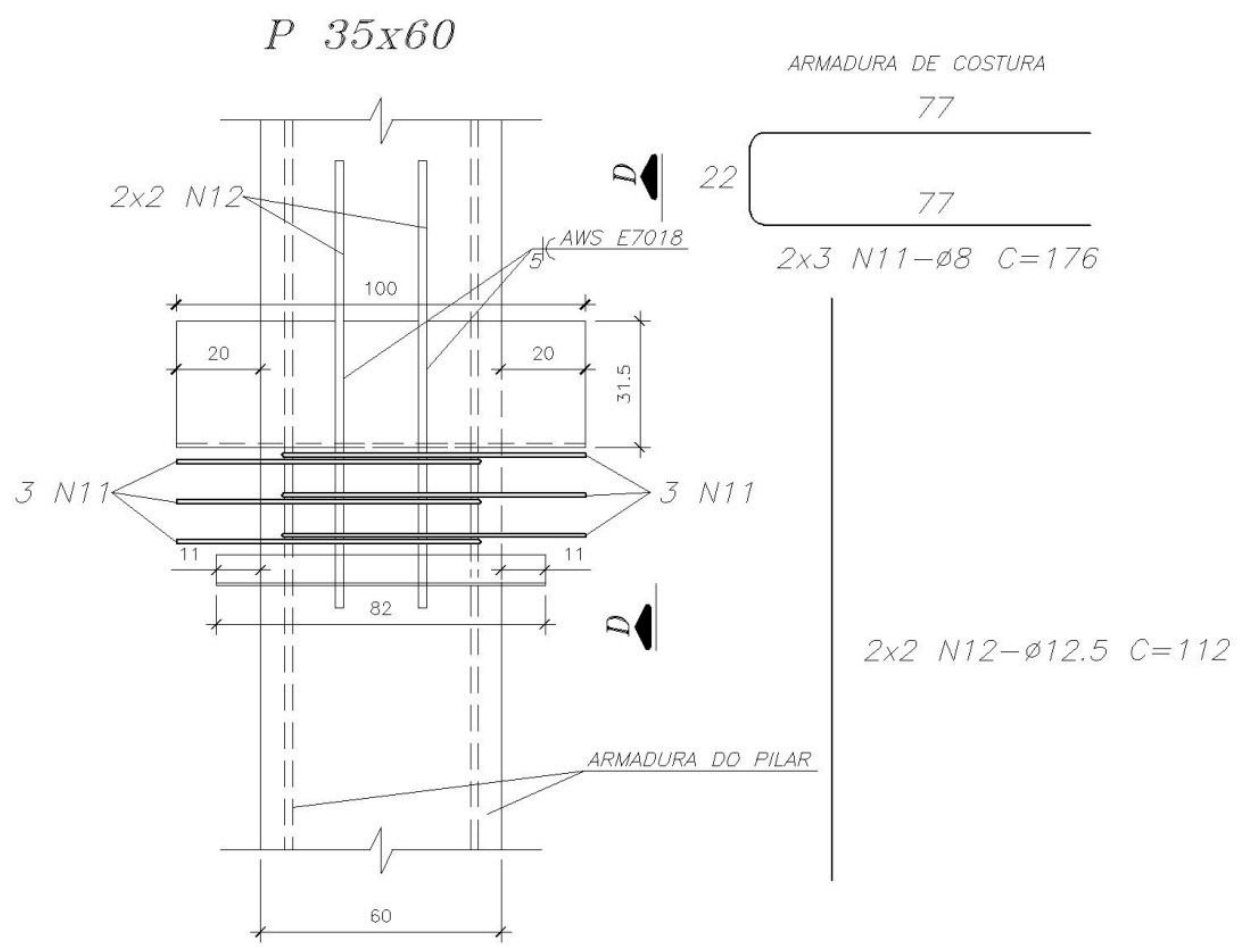

Figura 3.6 - a) Detalhe da armadura do pilar; b) Detalhe do pilar da região de ligação. 

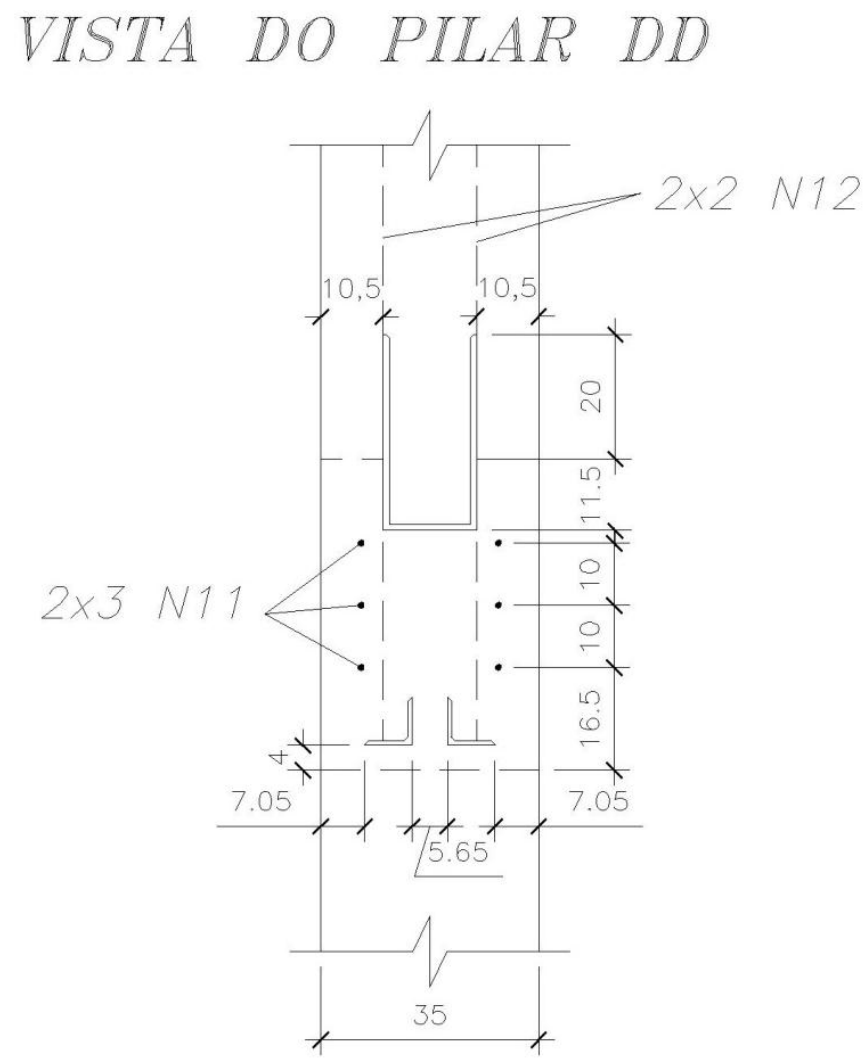

Figura 3.7 - Detalhamento das armaduras do pilar e dos elementos da ligação.

CONSOLO METALICO PERFIL U (X1)

DENTE METALICO PERFIL TUBULAR RETANGULAR (X2)
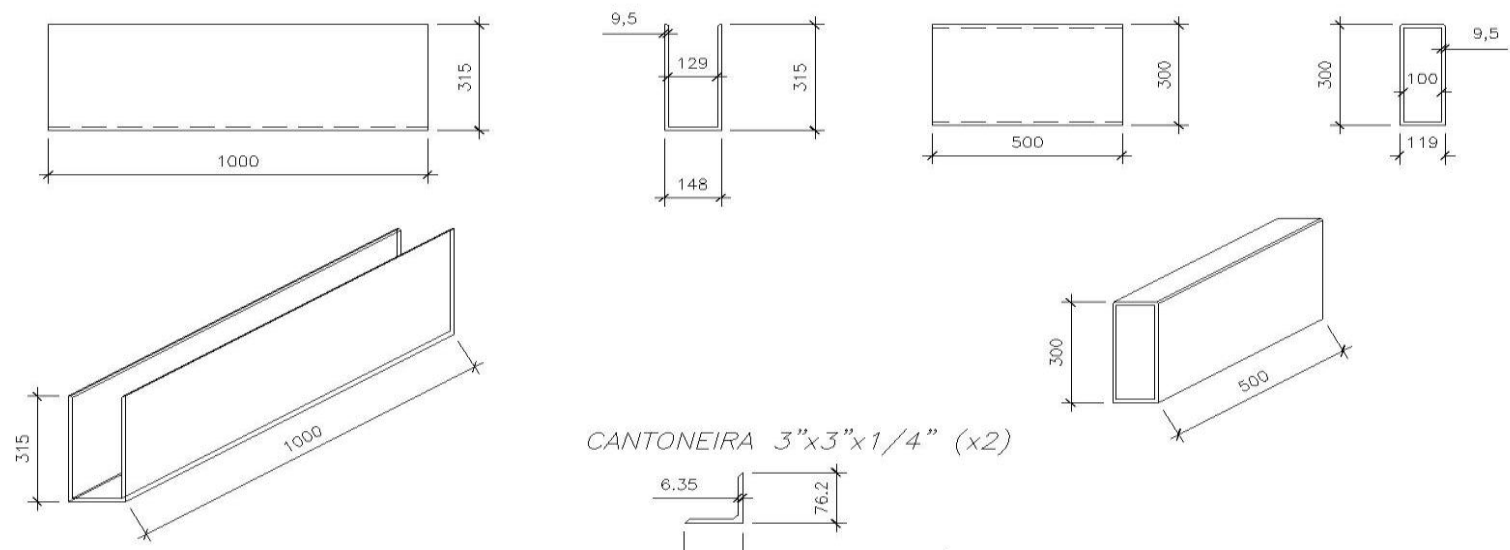

NOTAS

MEDIDAS EM mm

AÇO ASTM ABE
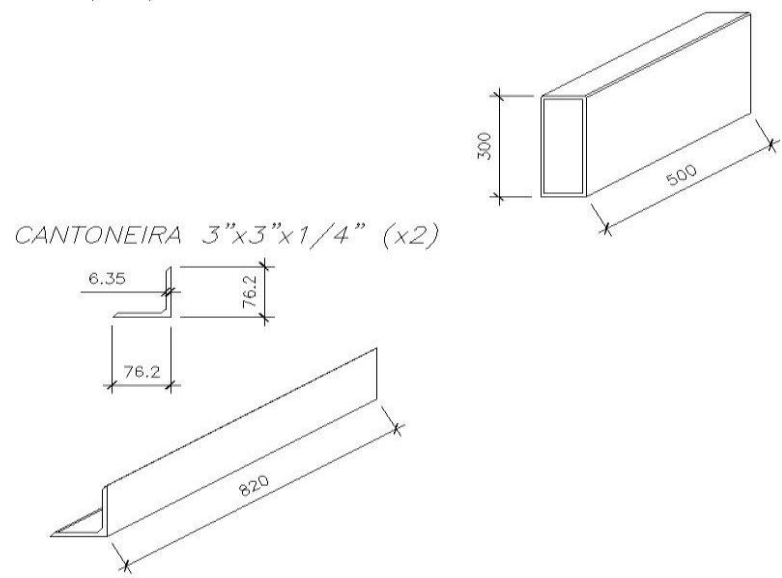

Figura 3.8 - Detalhe dos elementos metálicos embutidos nas vigas e no pilar. 


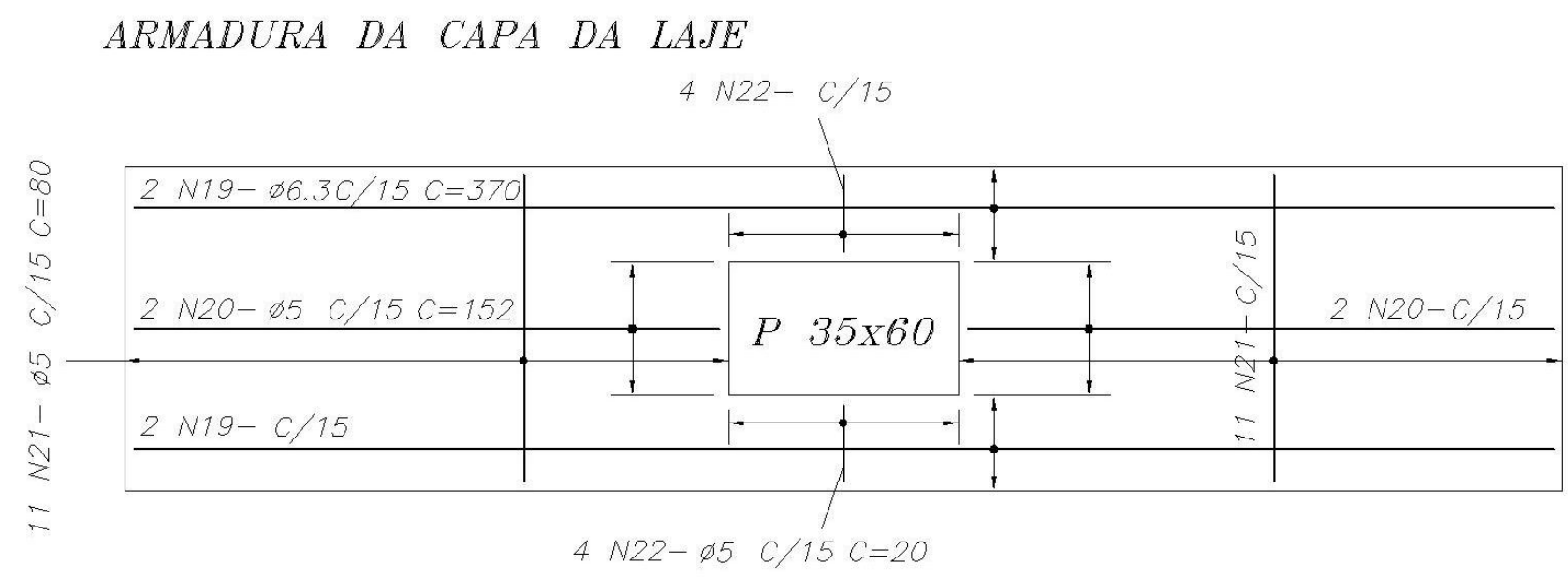

Figura 3.9 - Detalhe da armadura da capa da laje.

Para garantir a ancoragem das armaduras positivas e negativas das vigas, foram soldadas barras transversais de mesmo diâmetro, ou seja, $25 \mathrm{~mm}$ na extremidade oposta das barras.

\subsection{CONFECÇÃO DOS MODELOS}

\subsubsection{Formas}

As formas foram confeccionadas com chapas de madeira compensada plastificada com $15 \mathrm{~mm}$ de espessura. Foram realizadas previamente as aberturas necessárias para a passagem dos perfis metálicos da ligação embutidos nos elementos pré-moldados. As chaves de cisalhamento foram moldadas usando tacos de madeira pregados na face interna das formas, com as dimensões conforme mostra a Figura 3.10. Foram moldadas seis chaves nas faces de cada elemento pré-moldado espaçadas de 30

mm.
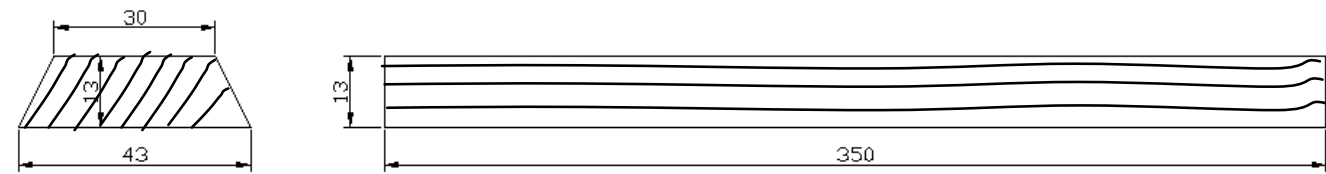

Figura 3.10 - Dimensões dos tacos utilizados para moldar as chaves de cisalhamento. 
Na Figura 3.11 observa-se a peça de fechamento da forma do pilar com os tacos de madeira pregados para moldar as chaves de cisalhamento.

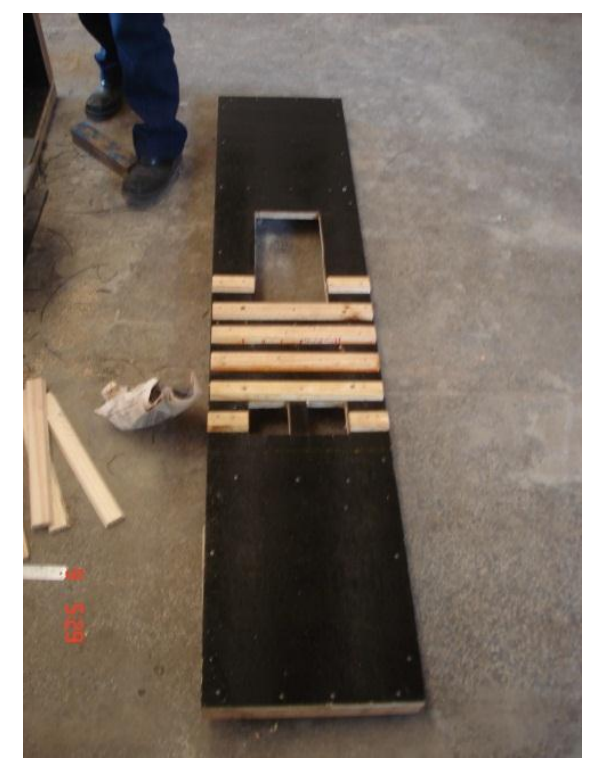

Figura 3.11 - Peça de fechamento lateral da forma do pilar com os recortes para a passagem dos perfis metálicos e os moldes das chaves de cisalhamento.

A Figura 3.12 apresenta o detalhamento das formas com as dimensões internas.

\section{FORMA DA VIGA (X2)}

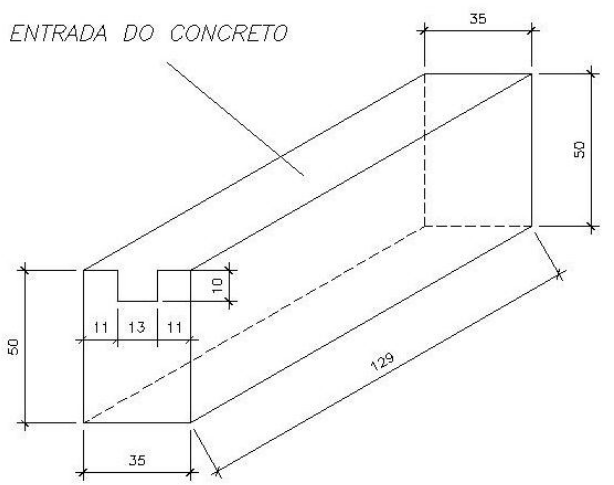

AREA

$2,10 \times 2=4,20 \mathrm{~m}^{2}$

NOTAS
FORMA DO PILAR (X1)
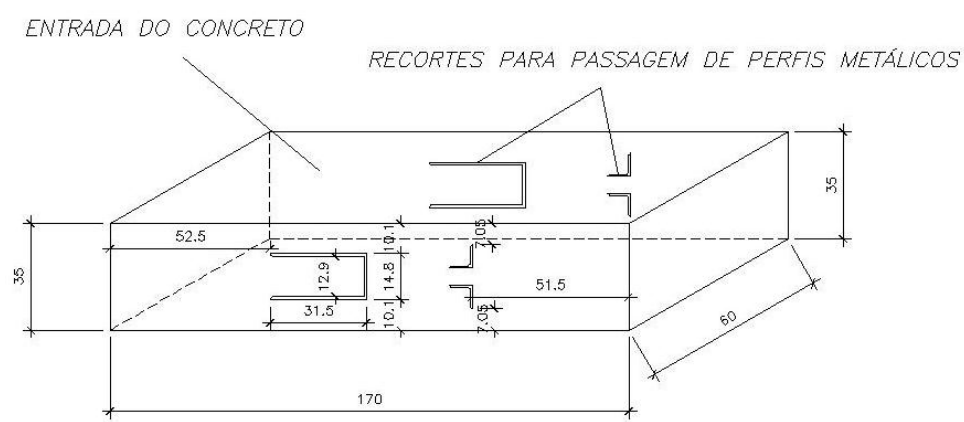

AREA

$2,63 \mathrm{~m}^{2}$

MEDIDAS INTERNAS

MEDIDAS EM cm

PREVER FOLGAS NOS RECORTES PARA PASSAGEM DOS PERFIS METALICOS

OS RECORTES PODEM SER FEITOS SEPARANDO EM PEÇAS PARA ENCAIXE

Figura 3.12 - Detalhamento das formas dos elementos pré-moldados. 


\subsubsection{Armação dos elementos pré-moldados}

Como os perfis metálicos estavam sendo projetados em uma empresa especializada, optou-se por realizar todas as soldas necessárias das armaduras nos perfis nessa empresa, e armar o restante no Laboratório de Estruturas da EESC/USP.

As armaduras negativas foram soldadas no dente metálico em ambos os lados das barras conforme Figura 3.13.

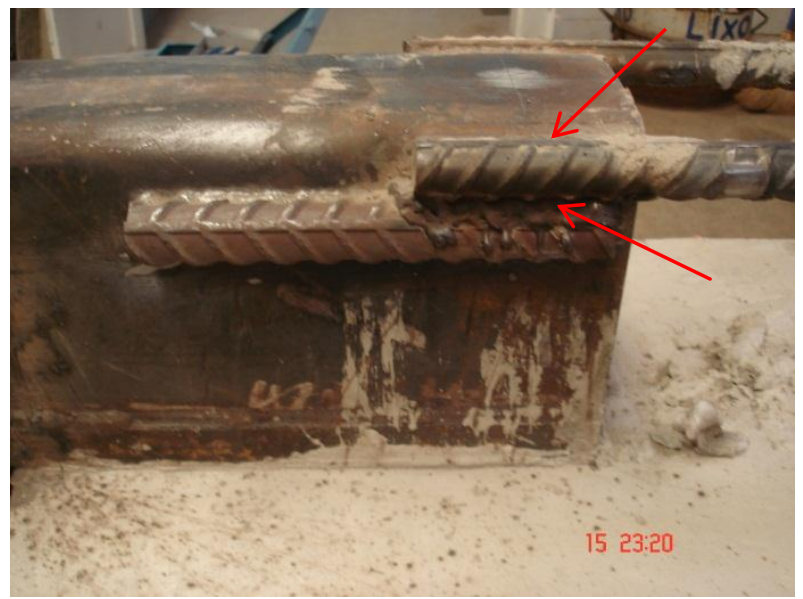

Figura 3.13 - Solda da armadura negativa no dente metálico.

A solda entre a barra de aço e o perfil metálico deve ser realizada por penetração parcial e com largura de $20 \%$ do diâmetro da armadura.

Foi utilizado o eletrodo E7018 com $\boldsymbol{f}_{\boldsymbol{w}}=\mathbf{4 8 5} \boldsymbol{M P \boldsymbol { a }}$. A verificação é feita da seguinte forma:

$$
\begin{aligned}
& t_{w}=0,2 d_{b}=0,2 \times 25=5,0 \mathrm{~mm} \\
& d_{e}=\frac{t_{w}}{\sqrt{2}}=3,54 \mathrm{~mm} \\
& l_{w}=100 \mathrm{~mm} \\
& F_{w}=0,6 d_{e} l_{w} f_{w}=0,6 x 0,354 \times 10 \times 48,5=103,01 \mathrm{kN} / \text { cordão }
\end{aligned}
$$

Como são 4 cordões de solda, 2 em cada barra da armadura,

$$
F_{w}=4 x 103,01=412,04 k N
$$


O comprimento da solda de 10,0 cm é insuficiente para suportar a força máxima solicitante nas armaduras negativas, portanto foi soldada uma barra de $20 \mathrm{~cm}$ no perfil e na armadura para elevar a resistência dessa ligação, conforme Figura 3.13.

As Figuras 3.15 e 3.16 apresentam a montagem das armaduras das vigas e pilares pré-moldados.

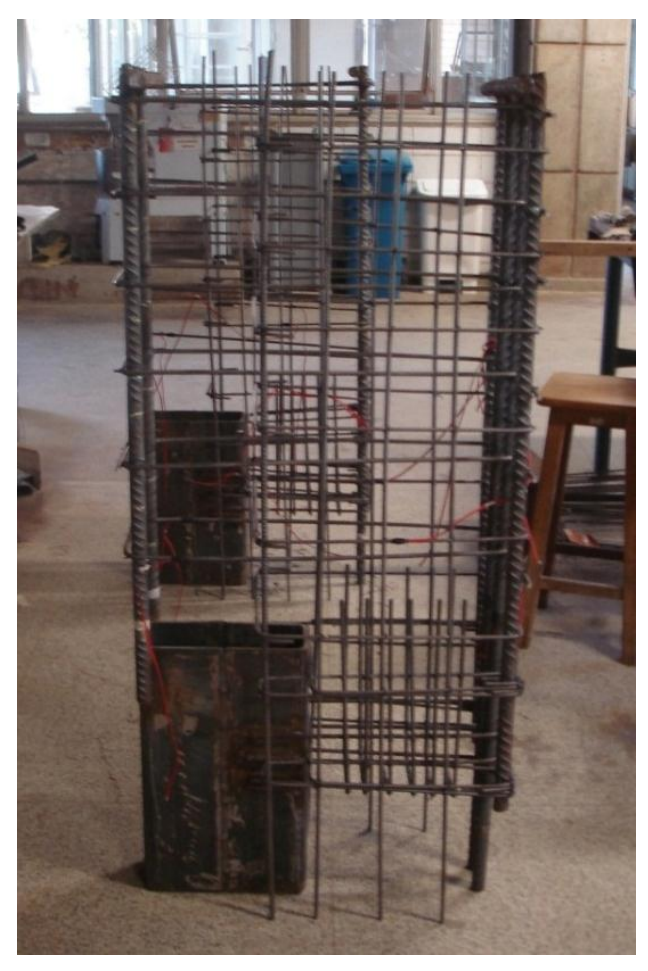

Figura 3.15 - Armadura da viga pré-moldada.

Neste caso, como parte das barras de aço foram soldadas ao perfil metálico embutido na viga, previamente à montagem da armadura, optou-se por executar a armação na direção vertical usando o dente metálico como apoio, pois facilitaria a montagem. 

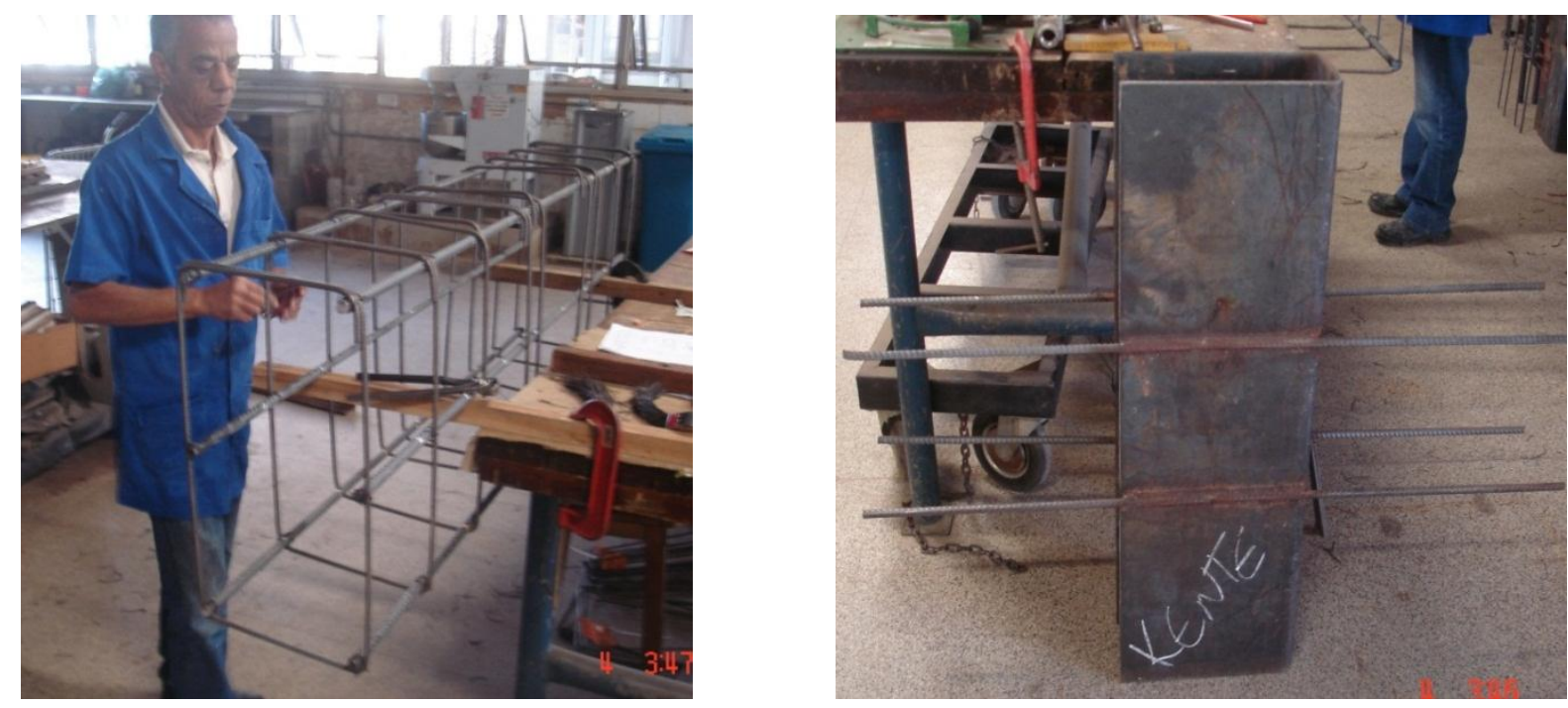

Figura 3.16 - Montagem da armadura do pilar pré-moldado.

Neste caso o perfil metálico foi encaixado após a armação do pilar.

As Figuras 3.17 e 3.18 apresentam em sequencia a colocação das armaduras do pilar e das vigas nas formas.
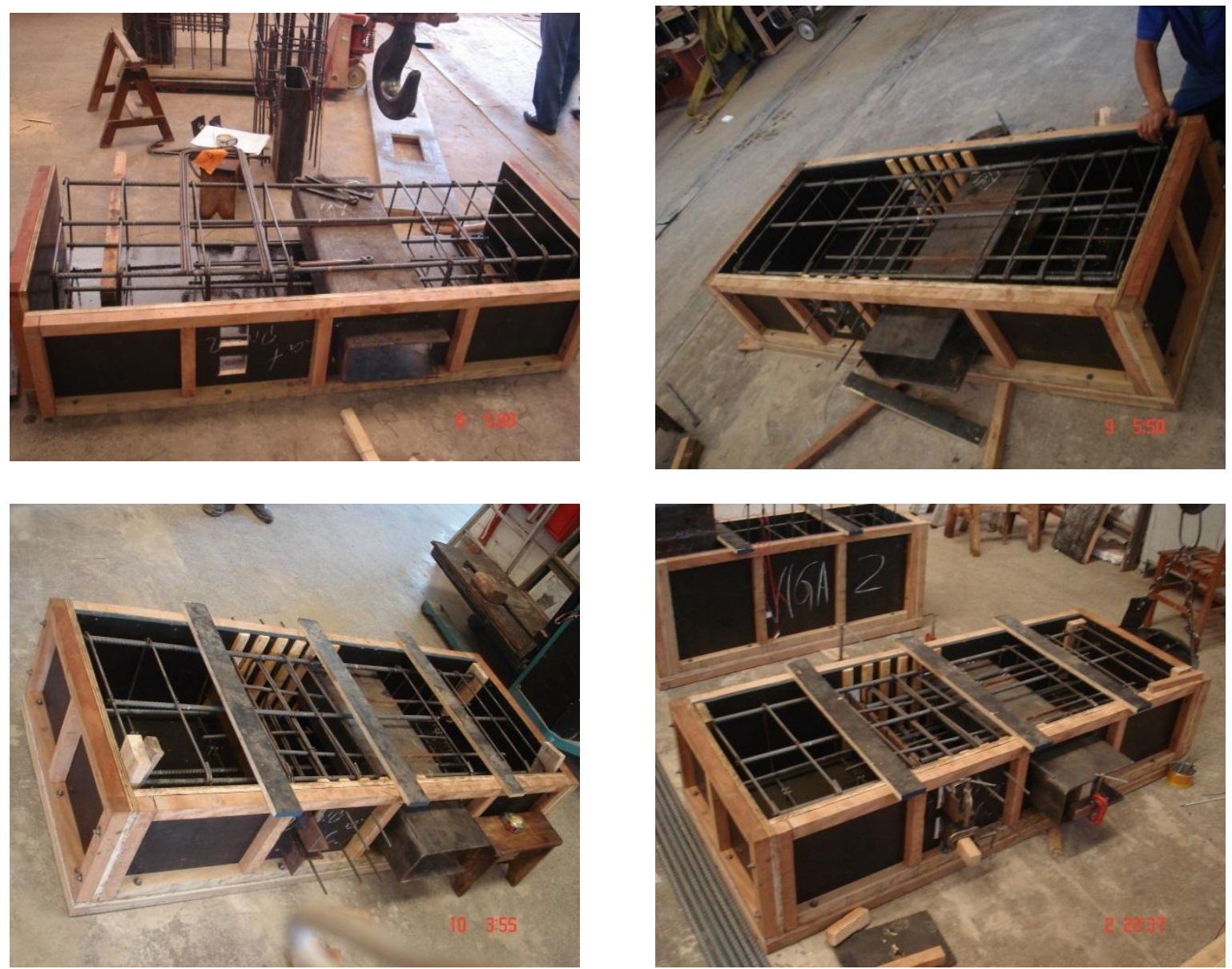

Figura 3.17 - Encaixe da armadura do pilar na forma. 

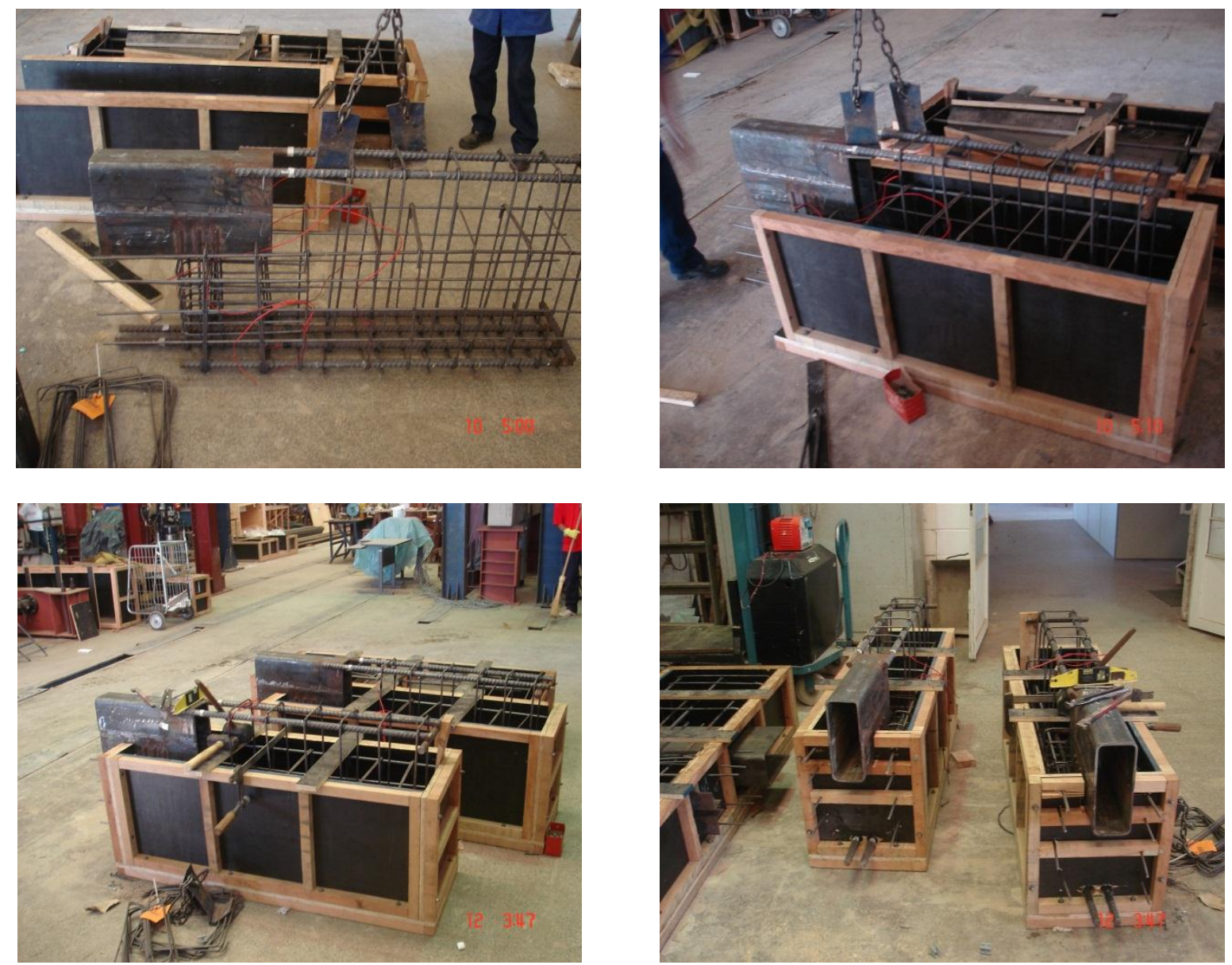

Figura 3.18 - Encaixe da armadura das vigas nas formas.

\subsubsection{Concretagem dos elementos pré-moldados}

Para a concretagem dos elementos pré-moldados foi utilizado concreto usinado fornecido pela CONCREBAND - Tecnologia em Concretos Ltda. de São Carlos. O concreto teve resistência especificada de $40 \mathrm{MPa}$ e slump de $6 \pm 1$. A Tabela 3.1 a seguir apresenta o traço em massa do concreto e as informações dos materiais utilizados pela usina. 
Tabela 3.1 - Traço do concreto utilizado na confecção dos elementos prémoldados.

\begin{tabular}{lccc}
\hline \multicolumn{1}{c}{ Material } & $\begin{array}{c}\text { Consumo } \\
\left(\mathbf{k g} / \mathbf{m}^{3}\right)\end{array}$ & Proporcão & Fornecedor \\
\hline Cimento CP III-40 & 399 & 1,00 & Holcim \\
Areia Fina & 190 & 0,48 & Itaporanga \\
Areia Grossa & 399 & 1,00 & Itaporanga \\
$\begin{array}{l}\text { Brita 1 } \\
\text { Aditivo } \\
\text { Superplastificante } \\
\text { Água }\end{array}$ & 1200 & 3,01 & Bandeirantes \\
\hline
\end{tabular}

No momento da concretagem o slump médio verificado para este concreto foi de $11,5 \mathrm{~cm}$. Foram utilizados $0,812 \mathrm{~m}^{3}$ de concreto.

As fotos da Figura 3.19 mostram o momento da concretagem dos elementos prémoldados.

Optou-se por manter fixado na cabeça do pilar, pelo lado externo da forma, o dispositivo metálico utilizado para ligar o modelo no atuador, para evitar que as barras de aço embutidas no pilar para realizar essa ligação sofresse algum deslocamento durante a concretagem que dificultasse a montagem do modelo no pórtico utilizado para o ensaio.

Os elementos concretados foram curados durante 05 dias envoltos em lona plástica para evitar a perda de água e foram umedecidos constantemente, após a cura foram desformados.

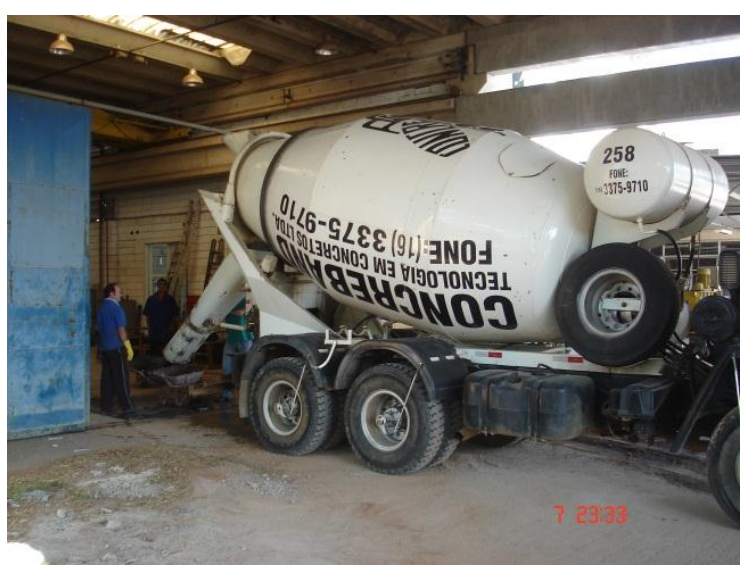

Fornecimento do concreto.

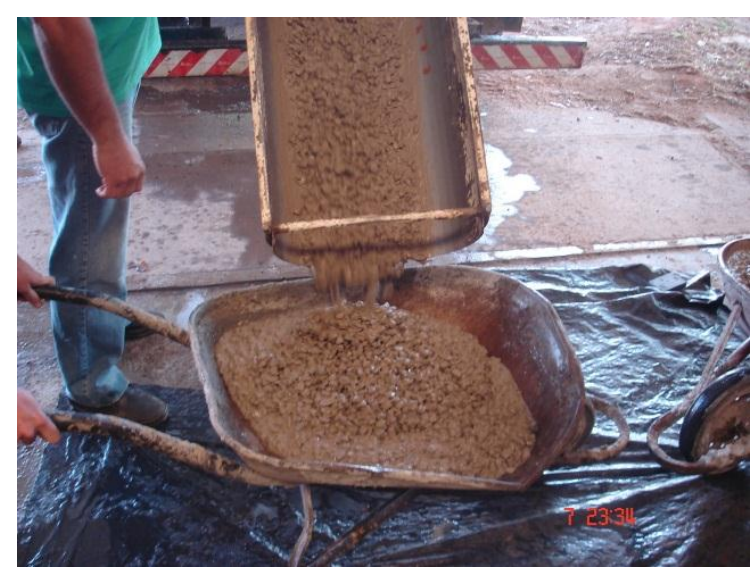

Aspecto do concreto. 


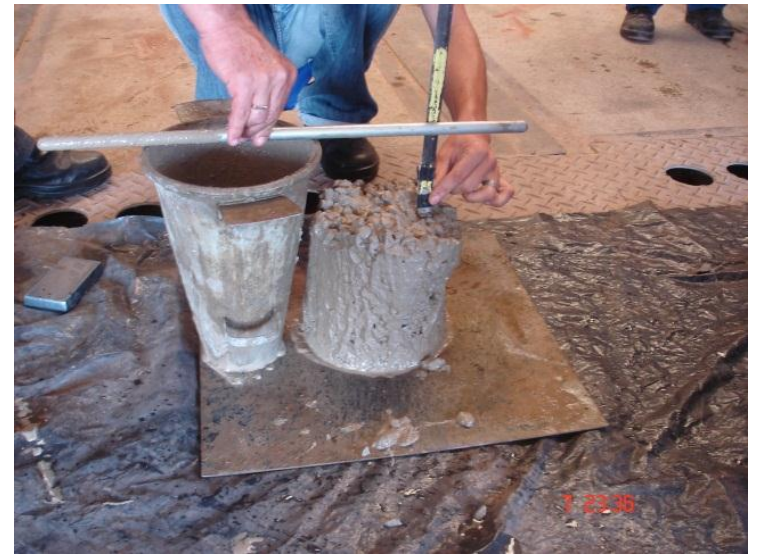

Ensaio de abatimento do tronco de cone.

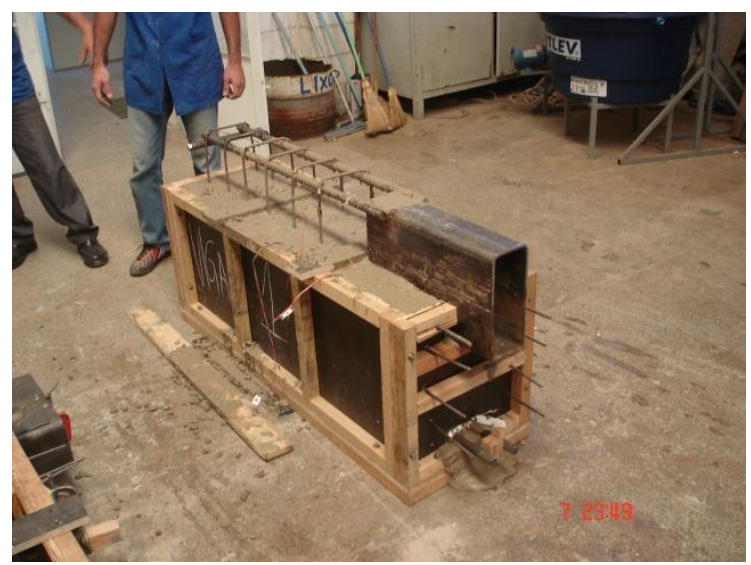

Viga totalmente concretada.

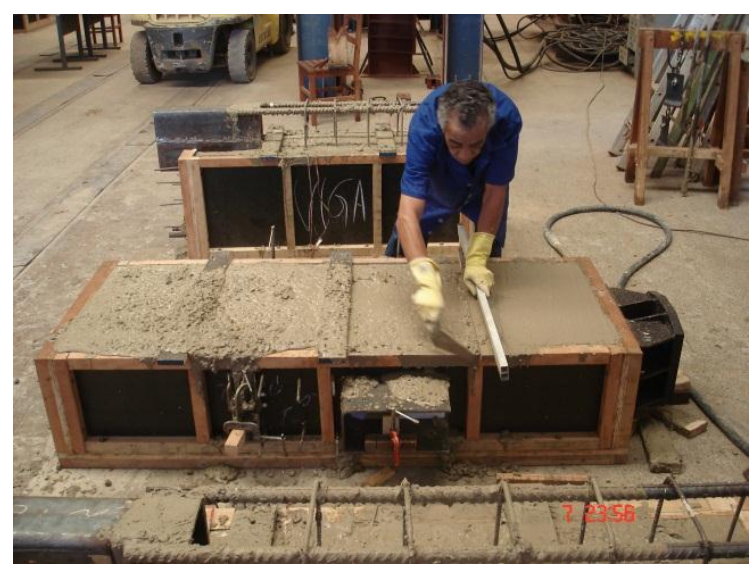

Acabamento na face do pilar.

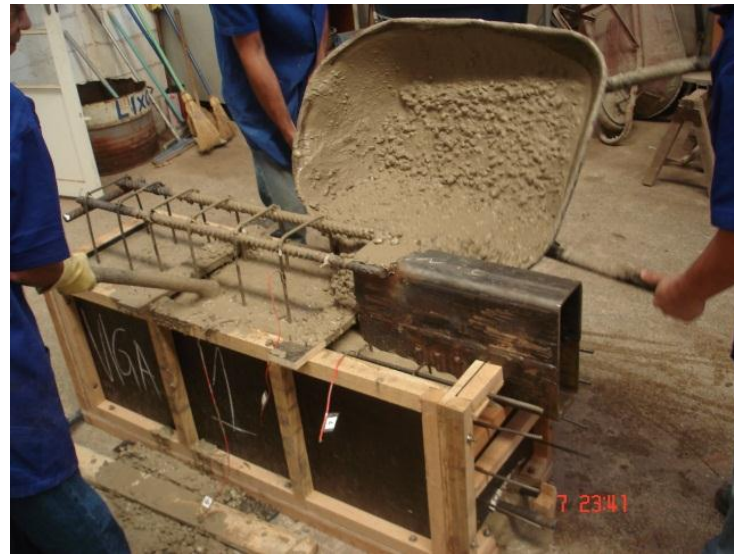

Concretagem da viga 1.

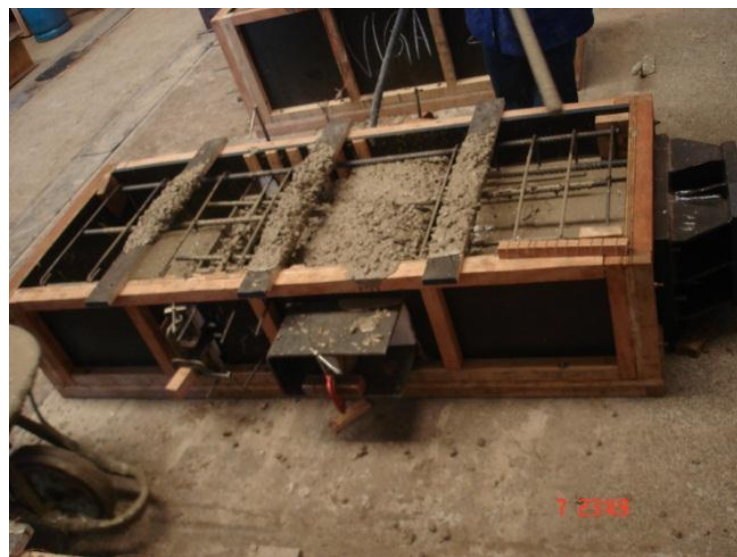

Concretagem do pilar.

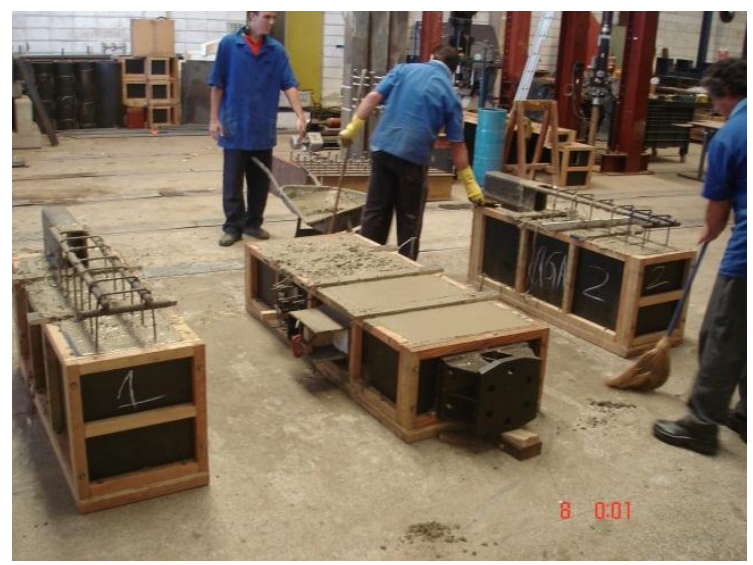

Elementos completamente concretados.

Figura 3.19 - Concretagem das vigas e pilar pré-moldado.

\subsubsection{Montagem do modelo}

A montagem do modelo seguiu a sequência descrita abaixo:

a) Posicionamento do pilar pré-moldado; 
b) Posicionamento das vigas pré-moldadas, encaixando os dentes metálicos no perfil "U" embutido no pilar;
c) Solda entre os perfis metálicos das vigas e do pilar;
d) Solda da armadura positiva da viga na cantoneira embutida no pilar;
e) Montagem da forma da ligação;
f) Concretagem da ligação;
g) Posicionamento dos painéis alveolares da laje;
h) Armação da capa da laje;
i) Concretagem da capa da laje.

As soldas entre os perfis metálicos da viga e o do pilar, e da armadura positiva da viga nas cantoneiras embutidas no pilar permitem que a ligação possua um comportamento de ligação rígida. Adotou-se como material de solda o eletrodo OCX ASW E7018.Foi necessário realizar solda de penetração parcial, e devido ao vão entre as almas do dente metálico e do consolo ser grande, foi usado um berço constituído por um pedaço e uma barra de aço de 8,0 $\mathrm{mm}$ para poder realizar o preenchimento do vão com o material da solda.

A Figura 3.20 apresenta a sequência de montagem do modelo até a execução das soldas.

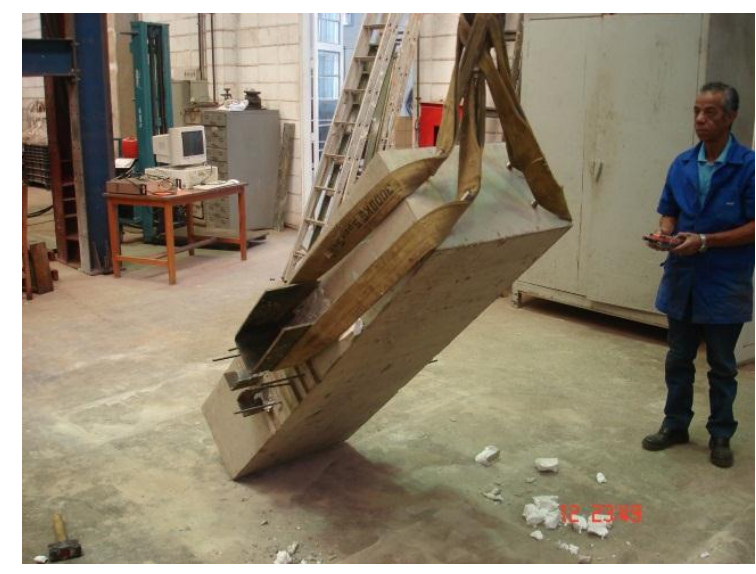

Içamento do pilar.

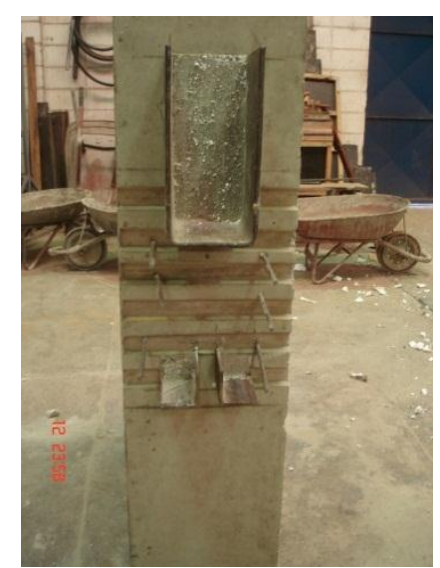

Detalhe dos elementos de ligação do pilar. 


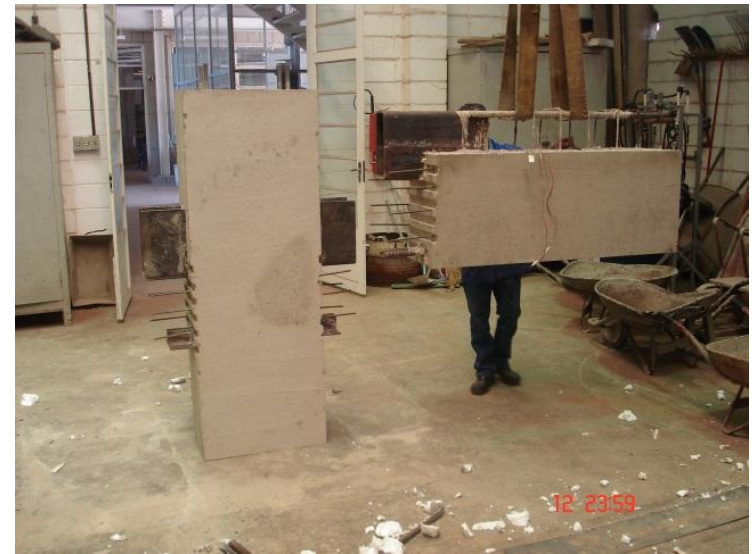

Içamento de uma das vigas.

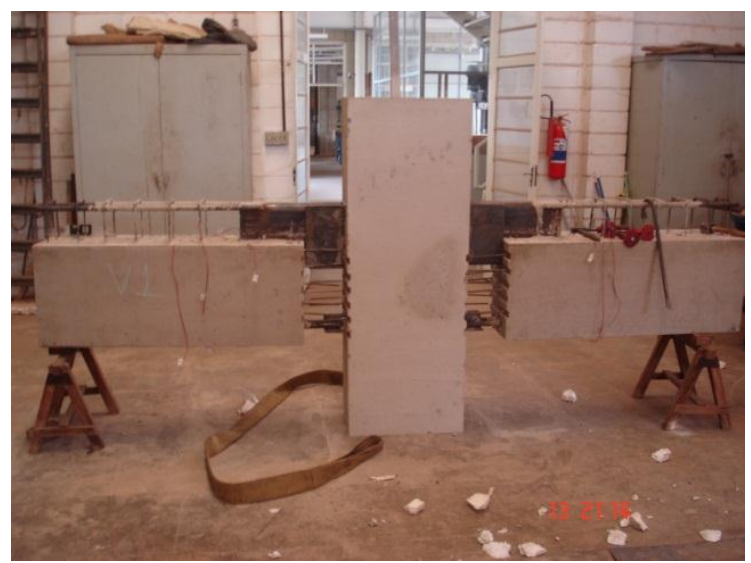

Vigas posicionadas e escoradas.

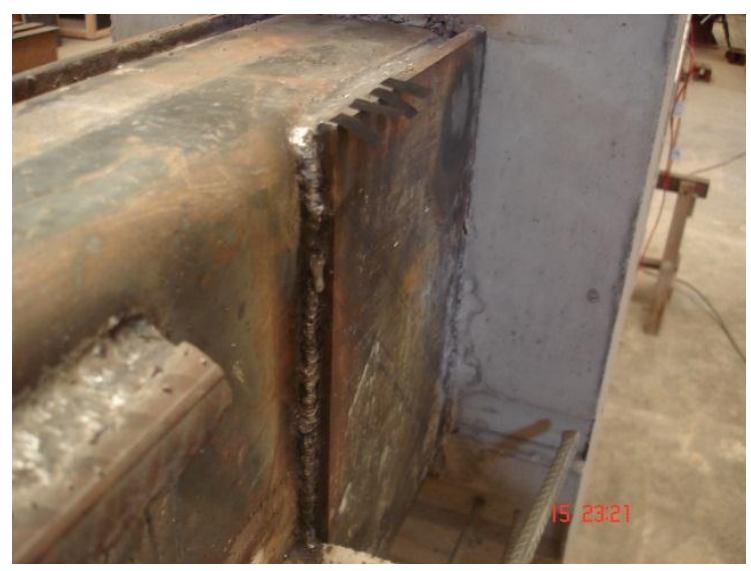

Detalhe da solda entre os perfis das vigas e pilar.

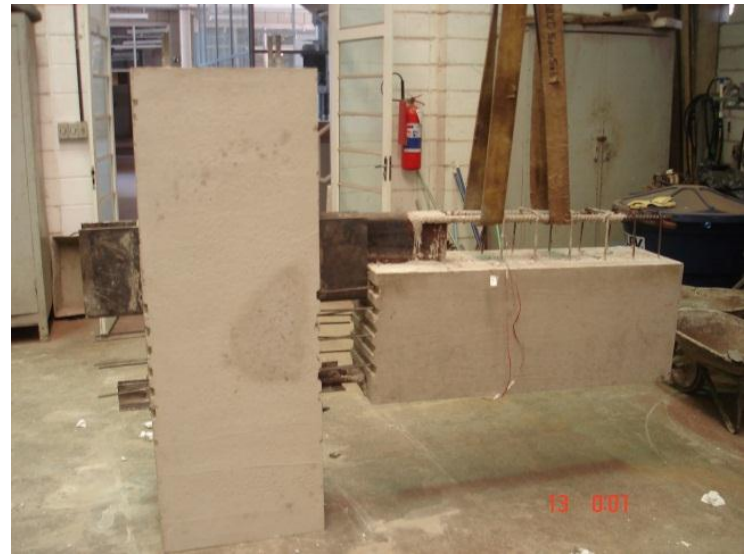

Posicionamento de uma das vigas.

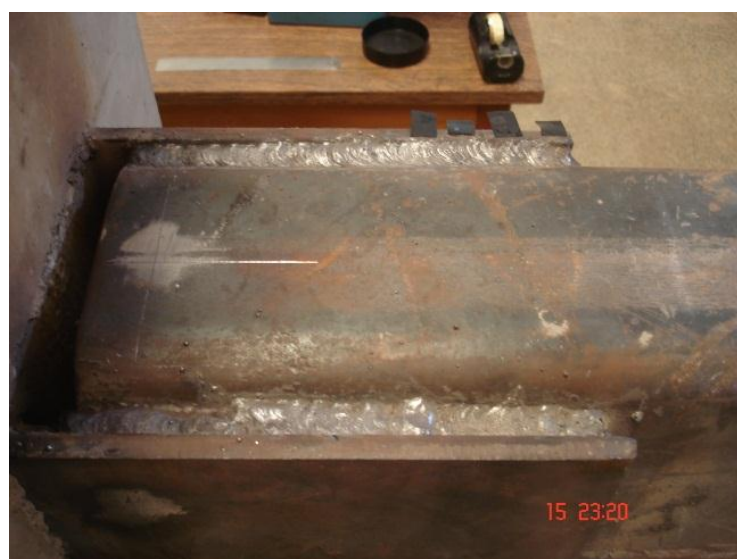

Detalhe da solda entre os perfis das vigas e pilar.

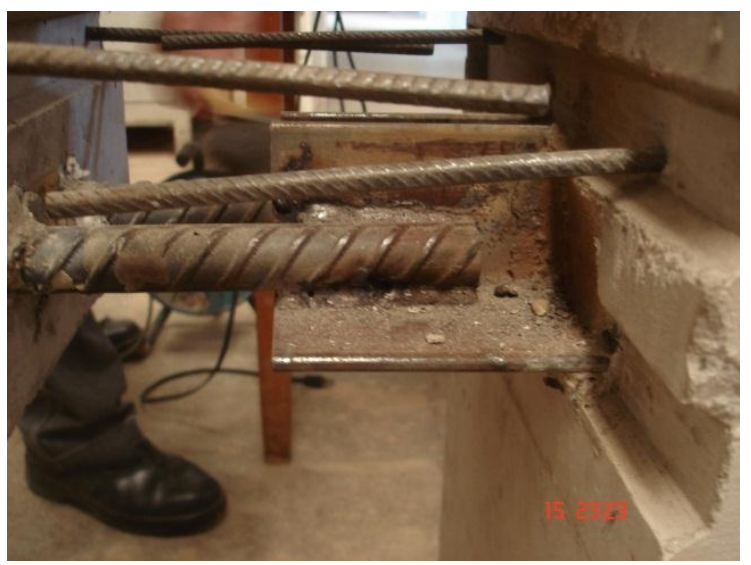

Solda da armadura positiva da viga nas cantoneiras.

Figura 3.20 - Sequência de montagem do modelo até a execução da solda.

Após a execução das soldas dos elementos de ligação, foram montadas as formas e concretada as ligações.

O concreto utilizado para preencher a ligação foi produzido no próprio Laboratório de Estruturas da Escola de Engenharia de São Carlos, conforme o traço em massa apresentado na Tabela 3.2. Para este concreto foi especificada uma resistência de $40 \mathrm{MPa}$ para ser 
compatível com a resistência do concreto utilizado nos elementos pré-moldados, e slump de 8 \pm 1 .

Tabela 3.2 - Traço do concreto utilizado para preencher as ligações viga-pilar.

\begin{tabular}{lccc}
\hline \multicolumn{1}{c}{ Material } & $\begin{array}{c}\text { Consumo } \\
\left(\mathbf{k g} / \mathbf{m}^{3}\right)\end{array}$ & Proporcão & Fornecedor \\
\hline Cimento CP IV ARI & 442 & 1,00 & $\begin{array}{c}\text { Holcim } \\
\text { Disponível no } \\
\text { Areia Grossa }\end{array}$ \\
Brita 1 & 608 & 1,38 & $\begin{array}{c}\text { Lispontónín no } \\
\text { Laboratório }\end{array}$ \\
Água & 1098 & 2,48 & - \\
\hline
\end{tabular}

O slump médio obtido para este traço foi de $7,5 \mathrm{~cm}$. No dia da concretagem da ligação o clima apresentava-se quente e seco com a temperatura ambiente em torno de $26^{\circ} \mathrm{C} \mathrm{e}$ a umidade relativa do ar de aproximadamente $34 \%$.

A Figura 3.21 mostra o momento da concretagem das ligações do modelo ensaiado.

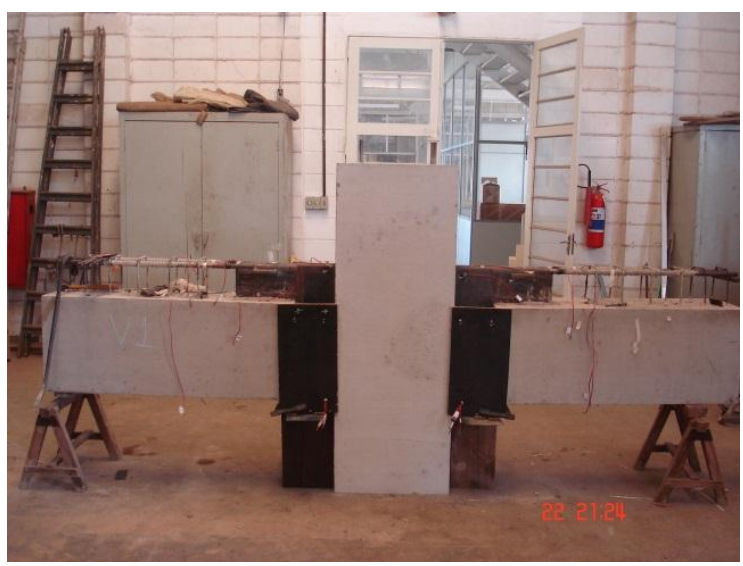

Montagem das formas das ligações.

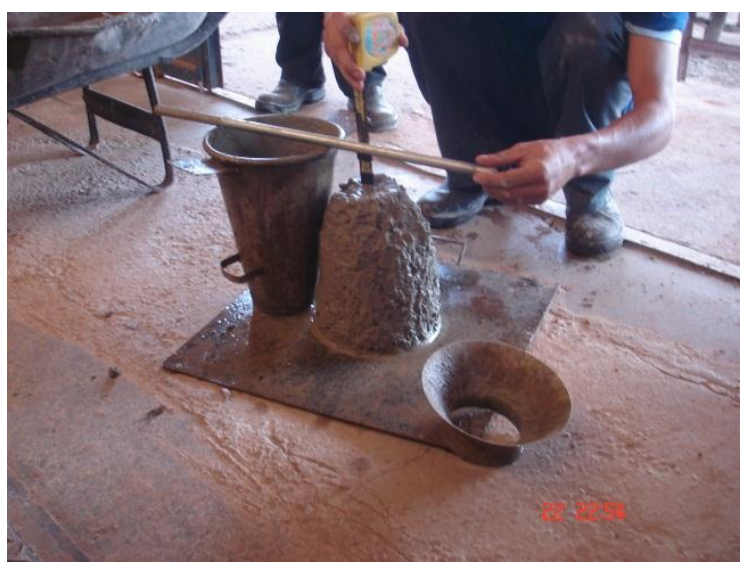

Ensaio de abatimento do tronco de cone.

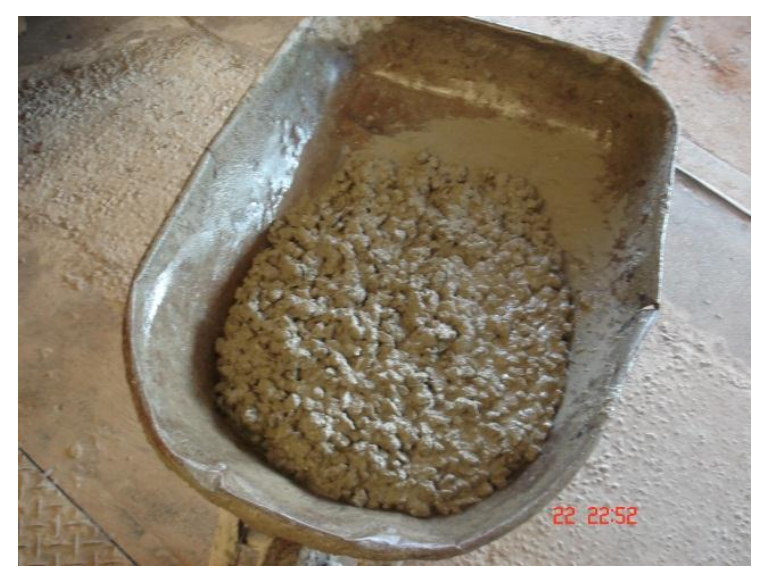

Aspecto do concreto.

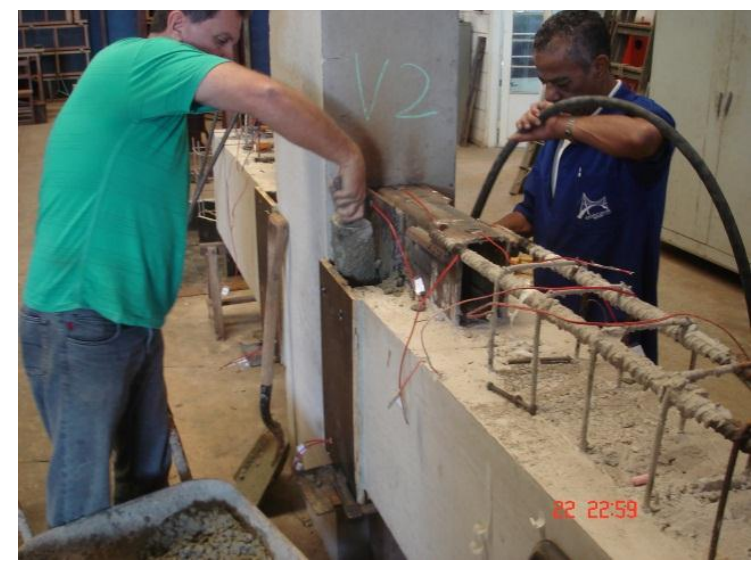

Concretagem das ligações. 


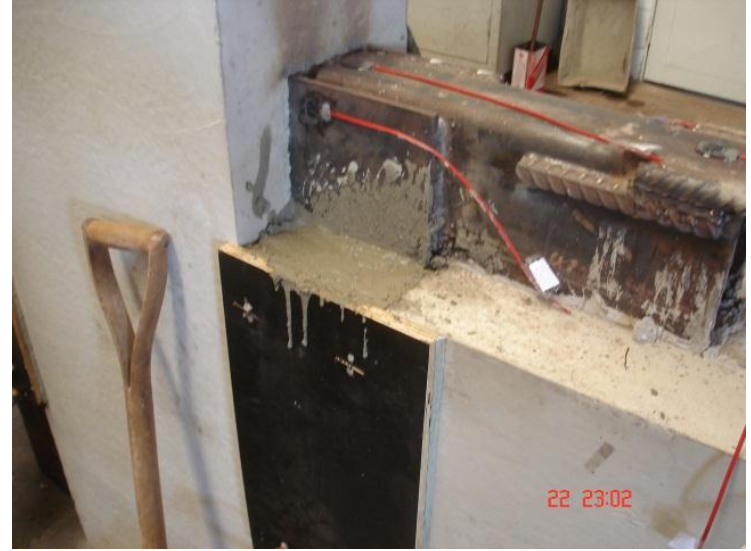

Ligação preenchida.

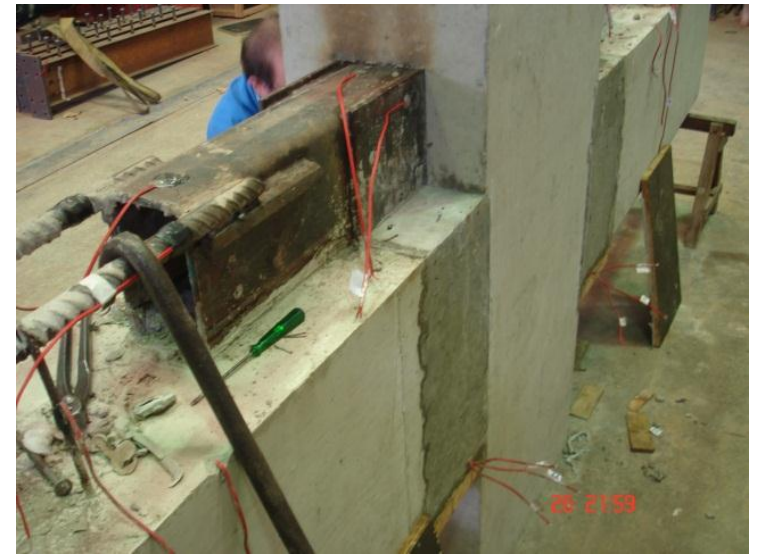

Aspecto do concreto da ligação após a desforma.

Figura 3.21 - Concretagem das ligações.

As formas das ligações foram retiradas 04 dias após a concretagem, passado esse período iniciou-se a montagem dos painéis de laje e a execução da forma e armação da capa da laje. Esta etapa pode ser vista na Figura 3.22.

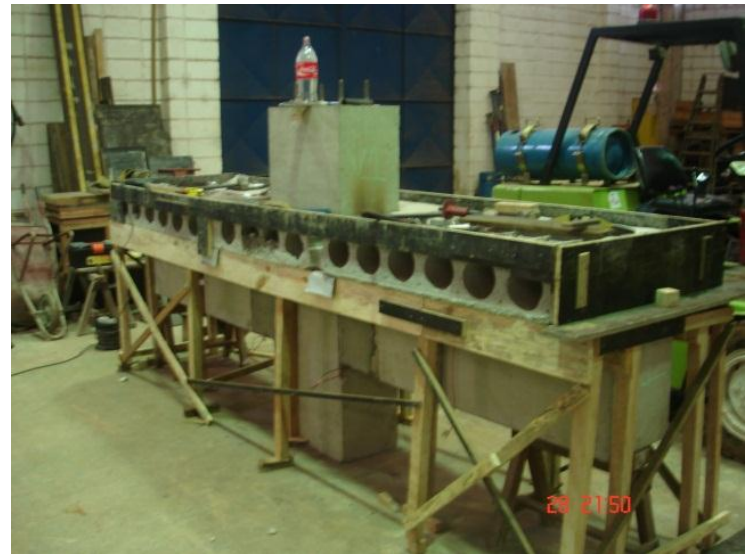

Escoramento dos painéis e forma da capa da laje.

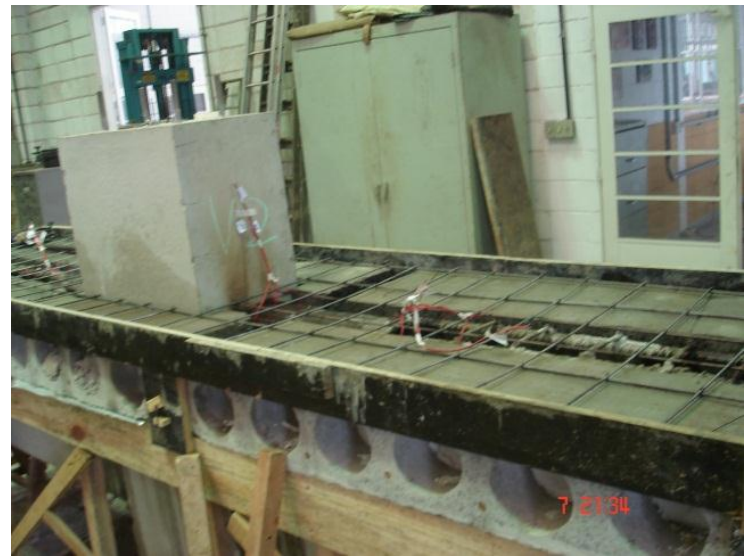

Armação da capa da laje.

Figura 3.22 - Etapa de execução da laje.

O concreto utilizado para executar a capa da laje foi produzido no próprio Laboratório de Estruturas da Escola de Engenharia de São Carlos, conforme o traço em massa apresentado na Tabela 3.3. Para este concreto foi especificada uma resistência de $30 \mathrm{MPa}$ para ser compatível com a resistência dos concretos utilizados para essa finalidade na maior parte das obras em concreto pré-moldado, e slump de $12 \pm 1$. 
Tabela 3.3 - Traço do concreto utilizado para executar a capa da laje.

\begin{tabular}{lccc}
\hline \multicolumn{1}{c}{ Material } & $\begin{array}{c}\text { Consumo } \\
\left(\mathbf{k g} / \mathbf{m}^{3}\right)\end{array}$ & Proporcão & Fornecedor \\
\hline Cimento CP IV ARI & 374 & 1,00 & $\begin{array}{c}\text { Holcim } \\
\text { Disponível no } \\
\text { Laboratório } \\
\text { Areia Grossa }\end{array}$ \\
Brita 1 & 935 & 2,50 & $\begin{array}{c}\text { Disponível no } \\
\text { Laboratório }\end{array}$ \\
Água & 935 & 2,50 & - \\
\hline
\end{tabular}

O slump médio obtido para este traço foi de $12 \mathrm{~cm}$. No dia da concretagem da ligação o clima apresentava-se frio e úmido com a temperatura ambiente em torno de $18^{\circ} \mathrm{C}$ e a umidade relativa do ar de aproximadamente $83 \%$.

A Figura 3.23 mostra o momento da concretagem da capa da laje.

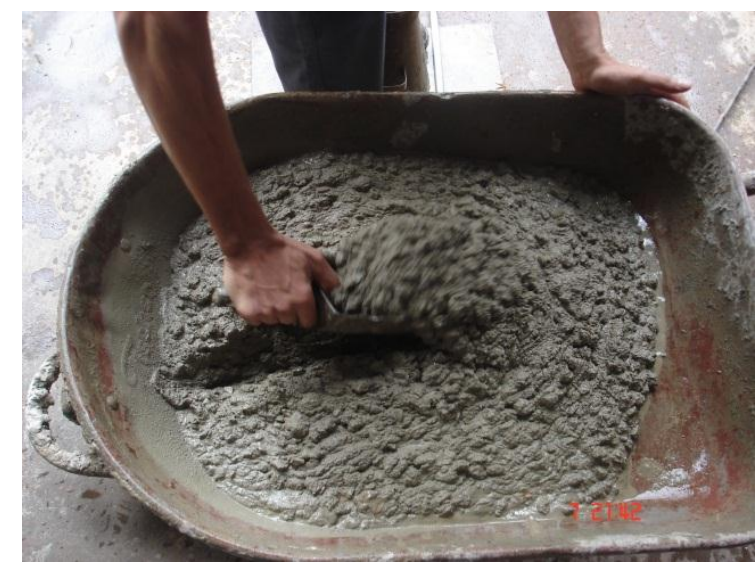

Aspecto do concreto.

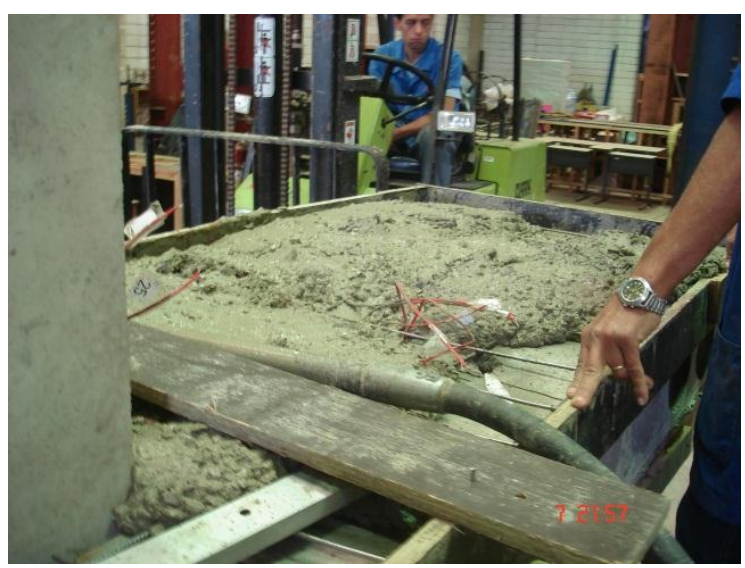

Concretagem da capa da laje.

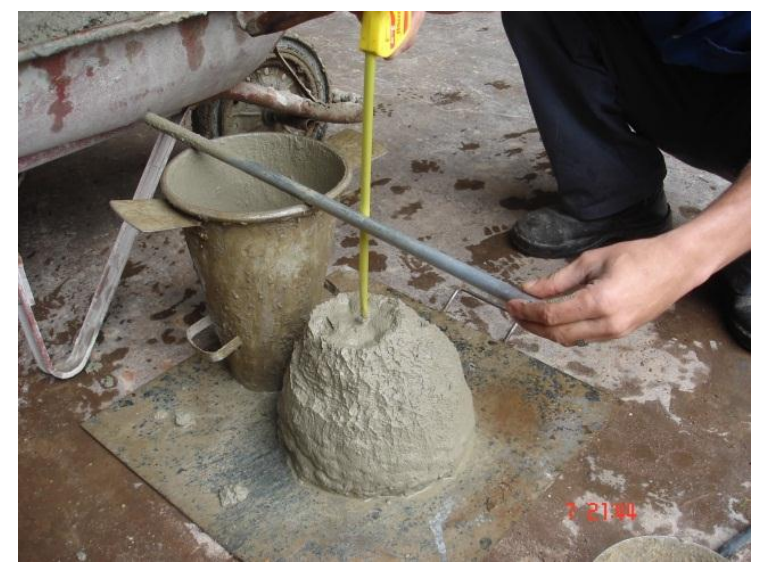

Ensaio de abatimento do tronco de cone.

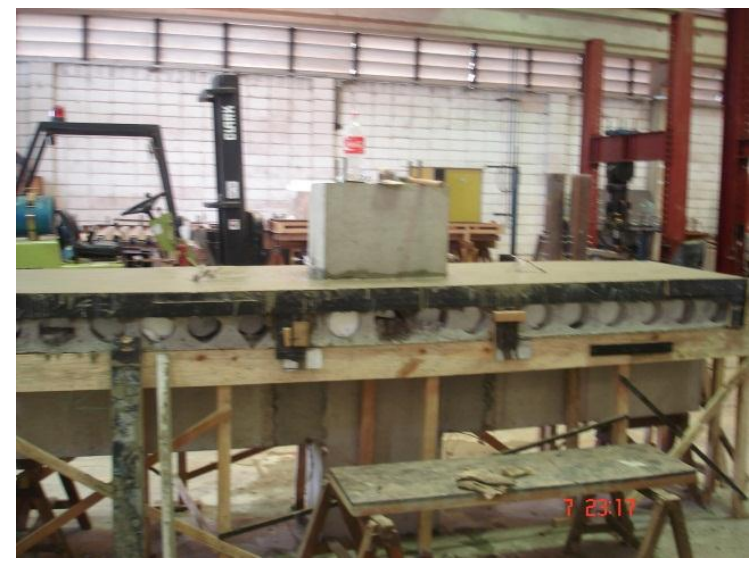

Laje completamento concretada.

Figura 3.23 - Concretagem da capa da laje. 


\subsection{PROPREIDADES MECÂNICAS DOS MATERIAIS}

\subsubsection{Concreto}

Para cada etapa de concretagem, sendo elas dos elementos pré-moldados, da ligação e da capa da laje, foram moldados 9 corpos de prova cilíndricos de $100 \mathrm{~mm}$ x $200 \mathrm{~mm}$, totalizando 27 corpos de prova. Estes foram desformados 1 dia após a concretagem e mantidos em câmara úmida até o dia do ensaio do modelo. O tempo de cura dos corpos de prova do concreto dos elementos pré-moldados foi de 48 dias, 33 dias para o concreto da ligação e 18 dias para o concreto da capa da laje.

Foram empregados 3 corpos de prova para a determinação da resistência à compressão, 3 para o ensaio de resistência à tração por compressão diametral e 3 para o ensaio de módulo de elasticidade. Os ensaios de módulo de elasticidade foram realizados no equipamento INSTRON 8506, e os demais ensaios foram realizados no equipamento hidráulico ELE Autotest 2000.

Os valores dos módulos de elasticidade dos concretos foram obtidos de acordo com as recomendações da norma NBR 8522:2008, e as resistências à compressão e à tração por compressão diametral foram calculadas conforme equações (3.1) e (3.2) respectivamente.

$$
f_{c j}=\frac{F o}{A}
$$

Onde:

$\boldsymbol{f}_{\boldsymbol{c} \boldsymbol{j}}=$ Resistência à compressão do corpo de prova na data $\mathrm{j}$

Fo = Força de ruptura

$\boldsymbol{A}=$ Área da seção transversal do corpo de prova

$$
f_{c t, s p}=\frac{2 F}{\pi \cdot d \cdot h}
$$

Onde:

$\boldsymbol{f}_{\boldsymbol{c t}, \boldsymbol{s p}}=$ Resistência à tração por compressão diametral 


$$
\begin{array}{ll}
\boldsymbol{F} & =\text { Força máxima aplicada } \\
\boldsymbol{d} & =\text { Diâmetro do corpo de prova } \\
\boldsymbol{h} & =\text { Comprimento do corpo de prova }
\end{array}
$$

As Tabelas 3.4 a 3.6 apresentam os resultados das resistências à compressão, tração por compressão diametral e módulo de elasticidade do concreto utilizado nos elementos prémoldados, as vigas e o pilar.

Tabela 3.4 - Resistência à compressão do concreto das vigas e do pilar.

\begin{tabular}{cc} 
Corpo de Prova & $\begin{array}{c}\text { Resistênca à compressão aos } \\
\mathbf{4 8} \text { dias (MPa) }\end{array}$ \\
\hline CP I & 45,0 \\
CP II & 44,8 \\
CP III & 40,6 \\
\hline Média & $\mathbf{4 3 , 5}$ \\
\hline
\end{tabular}

Tabela 3.5 - Resistência à tração por compressão diametral do concreto das vigas e pilar.

\begin{tabular}{cc} 
Corpo de Prova & $\begin{array}{c}\text { Resistênca à tração por } \\
\text { compressão diametral aos } 48 \\
\text { dias (MPa) }\end{array}$ \\
\hline CP I & Descartado \\
CP II & 3,9 \\
CP III & 3,6 \\
\hline Média & $\mathbf{3 , 8}$ \\
\hline
\end{tabular}


Tabela 3.6 - Módulo de elasticidade tangente do concreto das vigas e pilar.

\begin{tabular}{cc}
\hline Corpo de Prova & $\begin{array}{c}\text { Módulo de elasticidade } \\
\text { tangente aos } 48 \text { dias (GPa) }\end{array}$ \\
\hline CP I & 35,10 \\
CP II & 39,97 \\
CP III & 35,78 \\
\hline Média & $\mathbf{3 6 , 9 5}$ \\
\hline
\end{tabular}

As Tabelas 3.7 a 3.9 apresentam os resultados das resistências à compressão, tração por compressão diagonal e módulo de elasticidade do concreto utilizado na ligação.

Tabela 3.7 - Resistência à compressão do concreto da ligação.

\begin{tabular}{cc} 
Corpo de Prova & $\begin{array}{r}\text { Resistênca à compressão aos } \\
\text { 33 dias (MPa) }\end{array}$ \\
\hline CP I & 50,2 \\
CP II & 51,9 \\
CP III & 51,5 \\
\hline Média & $\mathbf{5 1 , 2}$ \\
\hline
\end{tabular}

Tabela 3.8 - Resistência à tração por compressão diametral do concreto da ligação.

\begin{tabular}{cc} 
Corpo de Prova & $\begin{array}{c}\text { Resistênca à tração por } \\
\text { compressão diametral aos 33 } \\
\text { dias (MPa) }\end{array}$ \\
\hline CP I & 3,4 \\
CP II & 3,4 \\
CP III & 3,9 \\
\hline Média & $\mathbf{3 , 6}$ \\
\hline
\end{tabular}


Tabela 3.9 - Módulo de elasticidade tangente do concreto da ligação.

\begin{tabular}{cc}
\hline Corpo de Prova & $\begin{array}{c}\text { Módulo de elasticidade } \\
\text { tangente aos } 33 \text { dias (GPa) }\end{array}$ \\
\hline CP I & 33,95 \\
CP II & 32,98 \\
CP III & 39,58 \\
\hline Média & $\mathbf{3 5 , 5 0}$ \\
\hline
\end{tabular}

As Tabelas 3.10 a 3.12 apresentam os resultados das resistências à compressão, tração por compressão diagonal e módulo de elasticidade do concreto utilizado na capa da laje.

Tabela 3.10 - Resistência à compressão do concreto da capa da laje.

\begin{tabular}{cc} 
Corpo de Prova & $\begin{array}{r}\text { Resistênca à compressão aos } \\
\mathbf{1 8} \text { dias (MPa) }\end{array}$ \\
\hline CP I & 43,2 \\
CP II & 42,5 \\
CP III & 41,5 \\
\hline Média & $\mathbf{4 2 , 4}$ \\
\hline
\end{tabular}

Tabela 3.11 - Resistência à tração por compressão diametral do concreto da capa da laje.

\begin{tabular}{cc} 
Corpo de Prova & $\begin{array}{c}\text { Resistênca à tração por } \\
\text { compressão diametral aos 18 } \\
\text { dias (MPa) }\end{array}$ \\
\hline CP I & 3,2 \\
CP II & 3,4 \\
CP III & 3,7 \\
\hline Média & $\mathbf{3 , 4}$ \\
\hline
\end{tabular}


Tabela 3.12 - Módulo de elasticidade tangente do concreto da capa da laje.

\begin{tabular}{cc}
\hline Corpo de Prova & $\begin{array}{c}\text { Módulo de elasticidade } \\
\text { tangente aos 18 dias (GPa) }\end{array}$ \\
\hline CP I & 35,59 \\
CP II & 36,15 \\
CP III & 38,56 \\
\hline Média & $\mathbf{3 6 , 7 7}$ \\
\hline
\end{tabular}

A resistência à compressão do concreto utilizado nas vigas e pilar foi compatível com a especificada, porém na ligação foi de aproximadamente $28 \%$ maior, e na capa da laje em torno de $21 \%$ maior que as especificadas. As imagens da Figura 3.24 apresentam os ensaios para obter as propriedades mecânicas dos concretos.

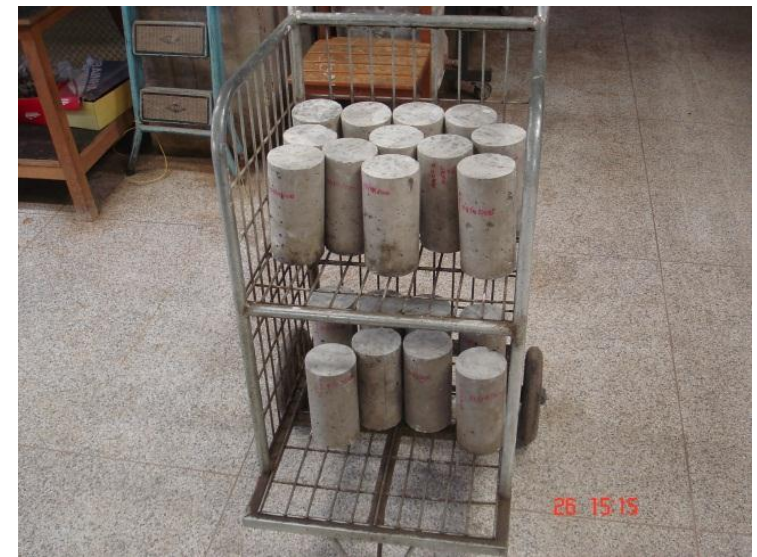

Corpos de prova.

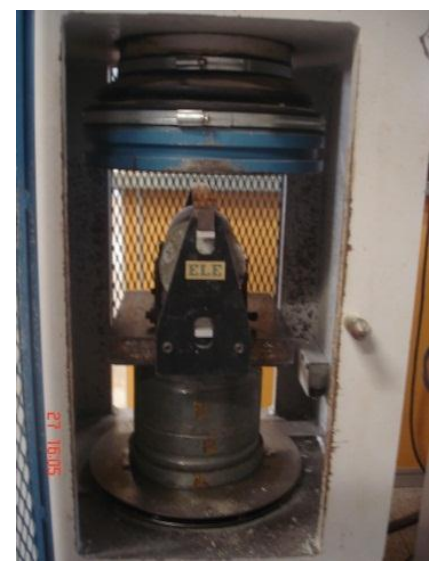

Ensaio de tração por compressão diametral.

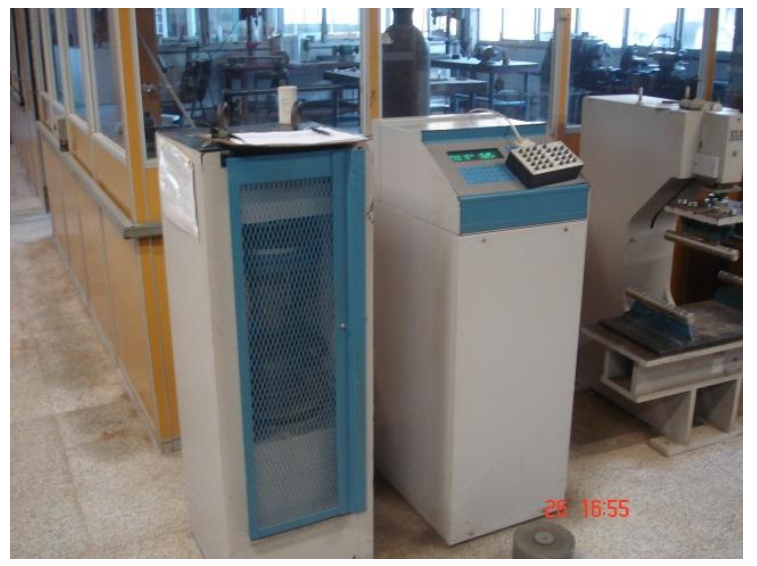

Ensaio à compressão.

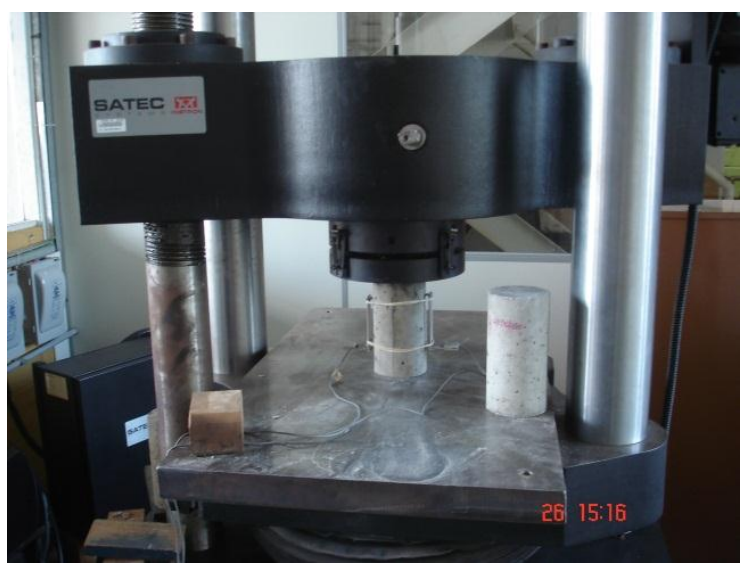

Ensaio de módulo de elasticidade.

Figura 3.24 - Ensaios de caracterização dos concretos. 


\subsubsection{Armadura}

As propriedades mecânicas do aço foram obtidas através do equipamento servo controlado INSTRON 8506 para todos os diâmetros utilizados. Foram ensaiadas 3 amostras de cada diâmetro e realizada a média aritmética dos resultados. Na Tabela 3.13 estão apresentadas as tensões médias de escoamento $\left(f_{y}\right)$, de ruptura $\left(f_{u}\right)$ e o módulo de elasticidades para cada diâmetro ensaiado.

Tabela 3.13 - Propriedades mecânicas do aço das armaduras.

\begin{tabular}{|c|c|c|c|c|c|}
\hline Diâmetro & Corpo de Prova & $f_{y}(\mathrm{MPa})$ & $f_{u}(\mathrm{MPa})$ & $f_{u} / f_{y}$ & E (GPa) \\
\hline \multirow{4}{*}{$8,0 \mathrm{~mm}$} & CP1 & 555,57 & 602,64 & 1,08 & ---- \\
\hline & $\mathrm{CP} 2$ & 537,37 & 596,02 & 1,11 & --- \\
\hline & $\mathrm{CP} 3$ & 535,31 & 622,38 & 1,16 & ---- \\
\hline & Média & 542,75 & 607,01 & 1,12 & --.-- \\
\hline \multirow{4}{*}{$10,0 \mathrm{~mm}$} & $\mathrm{CP} 1$ & 615,94 & 675,20 & 1,10 & ---- \\
\hline & $\mathrm{CP} 2$ & 600,40 & 662,57 & 1,10 & ---- \\
\hline & CP3 & 607,20 & 661,60 & 1,09 & ---- \\
\hline & Média & 607,85 & 666,46 & 1,10 & ---- \\
\hline \multirow{4}{*}{$12,5 \mathrm{~mm}$} & $\mathrm{CP} 1$ & 611,20 & 619,29 & 1,01 & 213,65 \\
\hline & $\mathrm{CP} 2$ & 571,41 & 597,52 & 1,05 & 217,75 \\
\hline & $\mathrm{CP} 3$ & 502,68 & 586,33 & 1,17 & 207,56 \\
\hline & Média & 561,76 & 601,05 & 1,07 & 212,99 \\
\hline \multirow{4}{*}{$16,0 \mathrm{~mm}$} & $\mathrm{CP} 1$ & 576,44 & 579,08 & 1,00 & 194,28 \\
\hline & $\mathrm{CP} 2$ & 555,95 & 568,48 & 1,02 & 213,69 \\
\hline & $\mathrm{CP} 3$ & 557,44 & 565,80 & 1,01 & 193,17 \\
\hline & Média & 563,28 & 571,12 & 1,01 & 200,38 \\
\hline \multirow{4}{*}{$20,0 \mathrm{~mm}$} & $\mathrm{CP} 1$ & 553,03 & 560,32 & 1,01 & 196,03 \\
\hline & $\mathrm{CP} 2$ & 561,05 & 565,67 & 1,01 & 212,46 \\
\hline & $\mathrm{CP} 3$ & 560,32 & 564,68 & 1,01 & 191,02 \\
\hline & Média & 558,13 & 563,56 & 1,01 & 199,84 \\
\hline \multirow{4}{*}{$25,0 \mathrm{~mm}$} & $\mathrm{CP} 1$ & 561,61 & 568,60 & 1,01 & 196,41 \\
\hline & $\mathrm{CP} 2$ & 556,64 & 574,81 & 1,03 & 194,27 \\
\hline & $\mathrm{CP} 3$ & 587,73 & 610,26 & 1,04 & 200,13 \\
\hline & Média & 568,66 & 584,56 & 1,03 & 196,94 \\
\hline
\end{tabular}

Observação: Para as barras de 8 e 10 mm, os resultados do módulo de elasticidade no ensaio de caracterização satisfatórios, portanto será adotado o valor teórico de 200 GPa. 


\subsubsection{Perfis metálicos}

As propriedades mecânicas dos perfis metálicos foram obtidas por meio da máquina EMIC DL10000 do Laboratório de Ensaios Mecânicos do Departamento de Engenharia de Materiais da EESC - USP. Foram ensaiados 7 corpos de prova, sendo 4 extraídos do material dos perfis metálicos que constituem o consolo do pilar e o dente embutido na viga com espessura de 9,5 mm, e 3 corpos de prova do material das cantoneiras metálicas embutidas no pilar com espessura de $6,3 \mathrm{~mm}$. O aço usado para todos os perfis metálicos foi o ASTM A36. Os corpos de prova foram extraídos conforme recomendações da norma ASTM A 370. A Figura 3.25 apresenta a forma e dimensões dos corpos de prova.

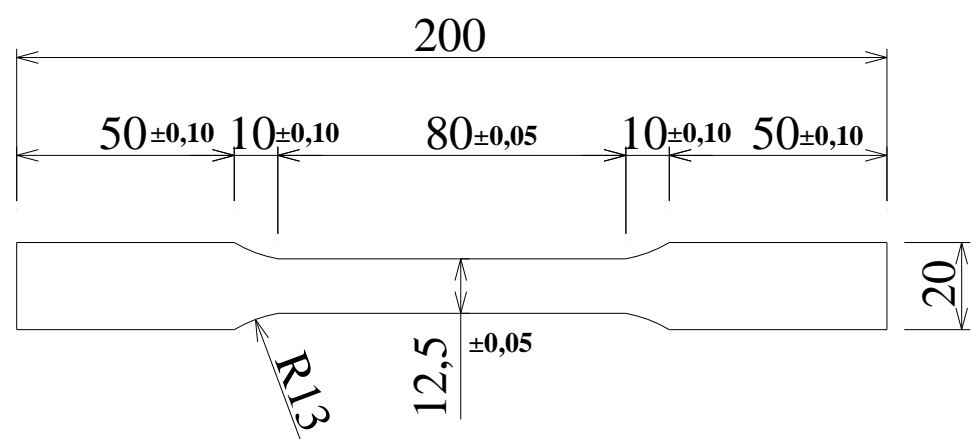

Figura 3.25 - Dimensões dos corpos de prova dos perfis metálicos (medidas em mm).

Na Tabela 3.14 estão apresentados os resultados das propriedades mecânicas dos perfis metálicos, e uma análise estatística desses resultados.

A Figura 3.26 mostra o aspecto dos corpos de prova depois de rompidos.

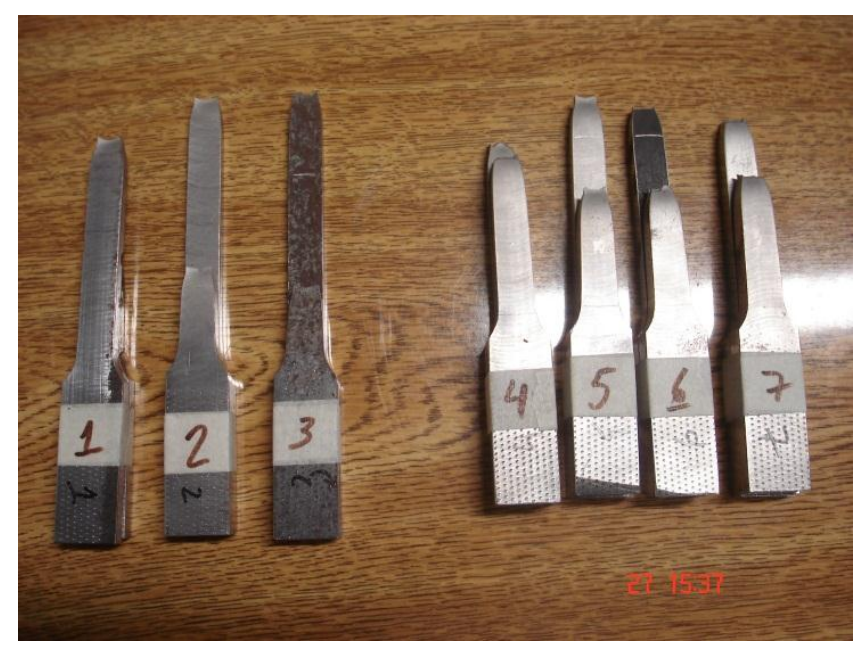

Figura 3.26 - Corpos de prova após ensaio de caracterização do aço dos perfis metálicos. 
Tabela 3.14 - Propriedades mecânicas dos perfis metálicos.

\begin{tabular}{|c|c|c|c|c|}
\hline $\begin{array}{l}\text { Elementos } \\
\text { Estruturais }\end{array}$ & $\begin{array}{l}\text { Corpo de } \\
\text { Prova }\end{array}$ & $\begin{array}{c}\text { Resitência à } \\
\text { Ruptura } \\
\text { (MPa) }\end{array}$ & $\begin{array}{c}\text { Resistência ao } \\
\text { Escoamento } \\
\text { (MPa) }\end{array}$ & $\begin{array}{c}\text { Módulo de } \\
\text { elasticidade } \\
\text { (GPa) }\end{array}$ \\
\hline \multirow{3}{*}{ Cantoneiras } & $\mathrm{CP} 1$ & 456,4 & - & - \\
\hline & $\mathrm{CP} 2$ & 449,9 & 309,1 & 211,69 \\
\hline & CP3 & 450,7 & 320,4 & 202,50 \\
\hline \multicolumn{2}{|c|}{ Média } & 452,3 & 314,8 & 207,1 \\
\hline \multirow{4}{*}{$\begin{array}{l}\text { Consolo e } \\
\text { dentes } \\
\text { metálicos }\end{array}$} & $\mathrm{CP} 4$ & 428,4 & 260,8 & ---- \\
\hline & CP5 & 429,6 & 259,1 & ---- \\
\hline & CP6 & 424,9 & 256,7 & ---- \\
\hline & CP7 & 424,7 & 256,3 & ---- \\
\hline \multicolumn{2}{|c|}{ Média } & 426,9 & 258,2 & ---- \\
\hline
\end{tabular}

Observação: Para o consolo e dentes metálicos adotou-se o valor teórico de 200 GPa para o módulo de elasticidade.

\subsection{EQUIPAMENTOS E INSTRUMENTAÇÃO}

Na Tabela 3.15 estão descritos os equipamentos e instrumentos utilizados para a realização do ensaio e medição. Estão apresentadas as marcas, modelos, características e função de cada equipamento e instrumento. 
Tabela 3.15 - Equipamentos e instrumentos de medição usados nos ensaios.

\begin{tabular}{|c|c|c|c|c|}
\hline $\begin{array}{c}\text { Equipamento / } \\
\text { Instrumento }\end{array}$ & Marca & Modelo & Características & Função \\
\hline $\begin{array}{c}\text { Sistema de } \\
\text { aquisição de dados } \\
\text { de transdutores }\end{array}$ & $\begin{array}{c}\text { Vishay } \\
\text { Measurements } \\
\text { Group, Inc. }\end{array}$ & $\begin{array}{l}\text { SYSTEM } \\
5000\end{array}$ & $\begin{array}{l}\text { Sistema de } \\
\text { aquisição de } \\
\text { dados }\end{array}$ & $\begin{array}{c}\text { Aquisição automática } \\
\text { de dados }\end{array}$ \\
\hline $\begin{array}{l}\text { Atuador servo- } \\
\text { controlado }\end{array}$ & INSTRON & A1891Y & $\begin{array}{c}\text { Capacidade } \\
\text { nominal de } 500 \\
\text { kN }\end{array}$ & $\begin{array}{l}\text { Aplicação de força } \\
\text { com controle de } \\
\text { deslocamento }\end{array}$ \\
\hline $\begin{array}{l}\text { Extensômetro } \\
\text { elétrico de } \\
\text { resis tência }\end{array}$ & KYOWA & $\begin{array}{c}\text { KFG - } 5- \\
120-\mathrm{C} 1- \\
11\end{array}$ & $\begin{array}{c}\text { GF } 2.12 \\
\text { Base } 5 \mathrm{~mm}\end{array}$ & $\begin{array}{l}\text { Medição das } \\
\text { deformações }\end{array}$ \\
\hline $\begin{array}{l}\text { Transdutor de } \\
\text { deslocame nto }\end{array}$ & KYOWA & DT100A & Curso de $100 \mathrm{~mm}$ & $\begin{array}{l}\text { Medição dos } \\
\text { deslocamentos }\end{array}$ \\
\hline $\begin{array}{l}\text { Trans dutor de } \\
\text { deslocame nto }\end{array}$ & $\begin{array}{c}\text { Vishay } \\
\text { Measurements } \\
\text { Group, Inc. }\end{array}$ & HS 25 & Curso de $25 \mathrm{~mm}$ & $\begin{array}{c}\text { Medição de } \\
\text { deslocamentos relativos }\end{array}$ \\
\hline Macaco hidráulico & Enerpac & RC506 & $\begin{array}{c}\text { Capacidade } \\
\text { nominal de } 500 \\
\text { kN }\end{array}$ & Aplicação de força \\
\hline $\begin{array}{l}\text { Máquina de ensaio } \\
\text { servo-controlada }\end{array}$ & INSTRON & 8506 & $\begin{array}{c}\text { Capacidade } \\
\text { nominal de } 2.500 \\
\mathrm{kN}\end{array}$ & $\begin{array}{c}\text { Caracterização dos } \\
\text { materiais }\end{array}$ \\
\hline
\end{tabular}

\subsubsection{Instrumentação interna}

A instrumentação interna é composta pelos extensômetros fixados nas armaduras das vigas, e nos perfis metálicos das vigas e pilar. No pilar só foram instrumentados os perfis metálicos, pois apenas esses elementos possuem influência na resistência da ligação. Os extensômetros foram numerados continuamente para os elementos pré-moldados totalizando 36 unidades. As Figuras 3.27 a 3.29 ilustram as posições dos extensômetros nas armaduras e nos perfis metálicos. O significado da denominação $1 / 2-14 / 15$, por exemplo, que indica a numeração dos extensômetros, está explicado na Tabela 3.16.

Tabela 3.16 - Convenção adotada para a numeração dos extensômetros.

\begin{tabular}{ccccccc}
\hline & Viga 1 & - & \multicolumn{3}{c}{ Viga 2} \\
1 & $/$ & 2 & - & 14 & $/$ & 15 \\
Lado direito & $/$ & Lado esquerdo & - & Lado direito & $/$ & Lado esquerdo \\
\hline
\end{tabular}


A convenção dos lados direito e esquerdo dos elementos pré-moldados foi definida olhando de frente para a face do elemento onde estão moldadas as chaves de cisalhamento.
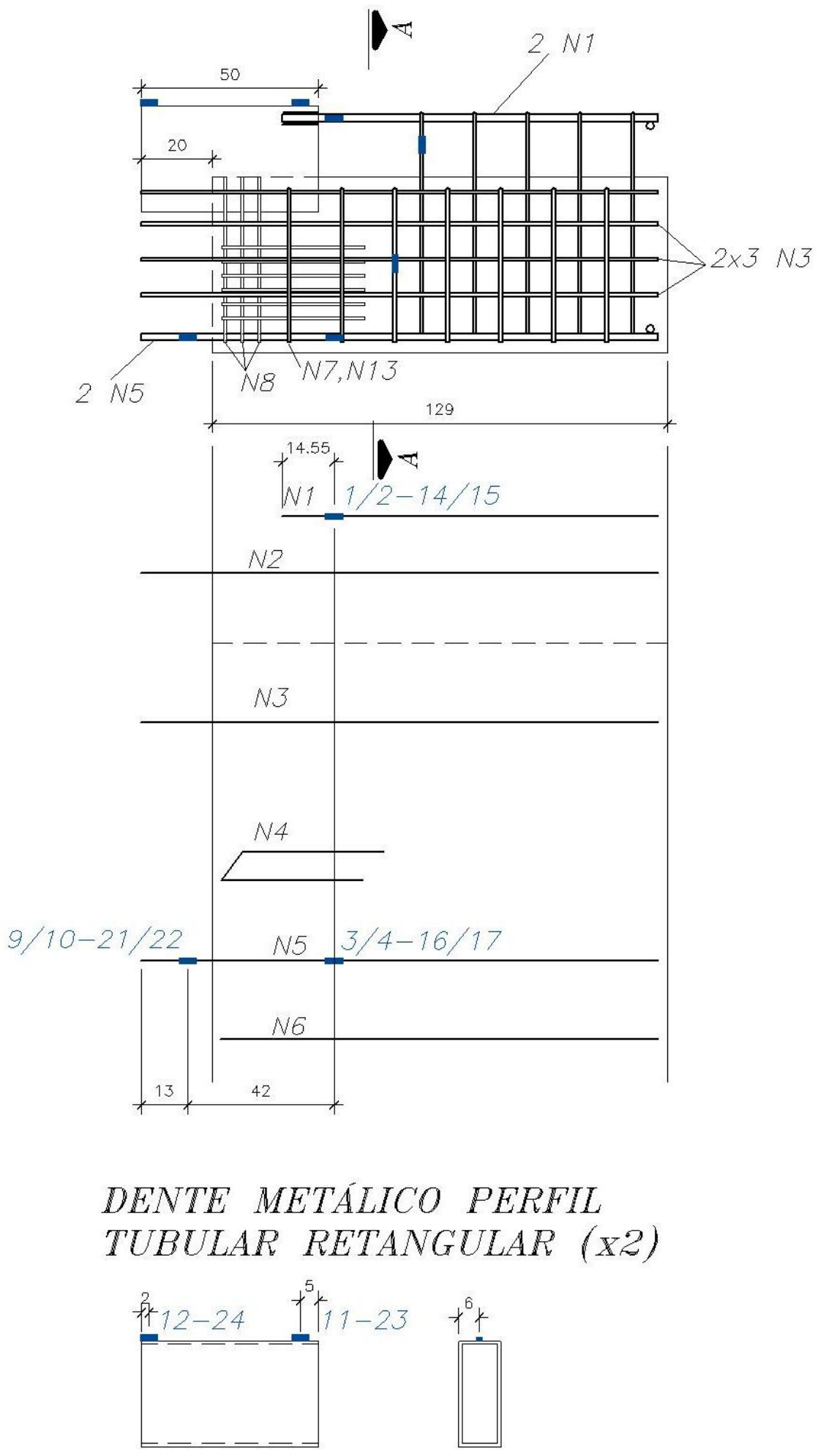

Figura 3.27 - Extensômetros das armaduras longitudinais e do perfil metálico embutidos nas vigas. 

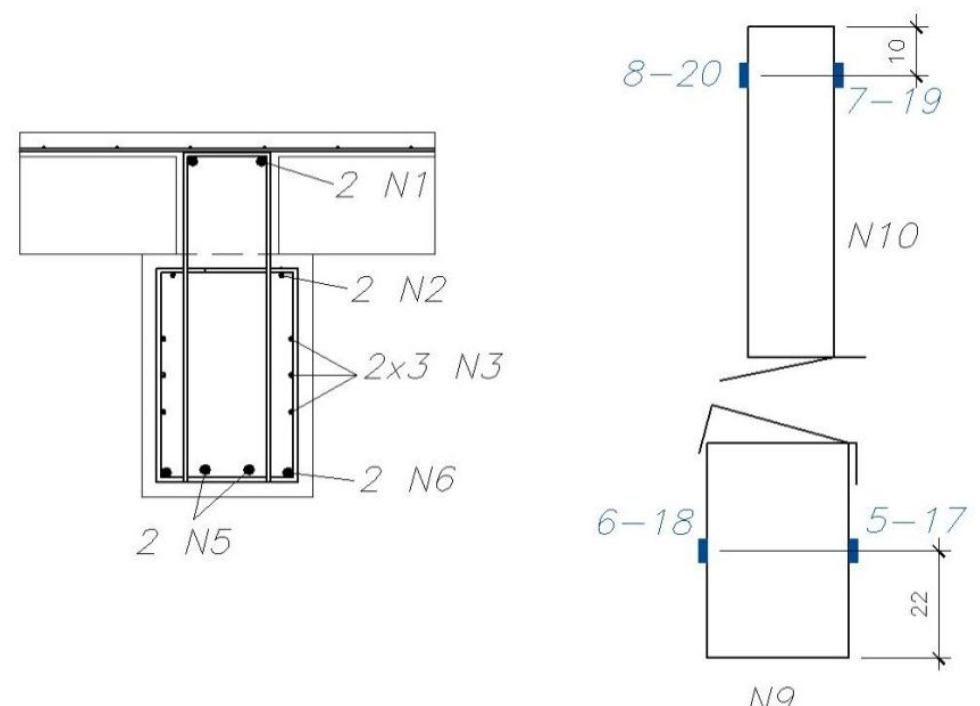

Figura 3.28 - Extensômetros das armaduras transversais.

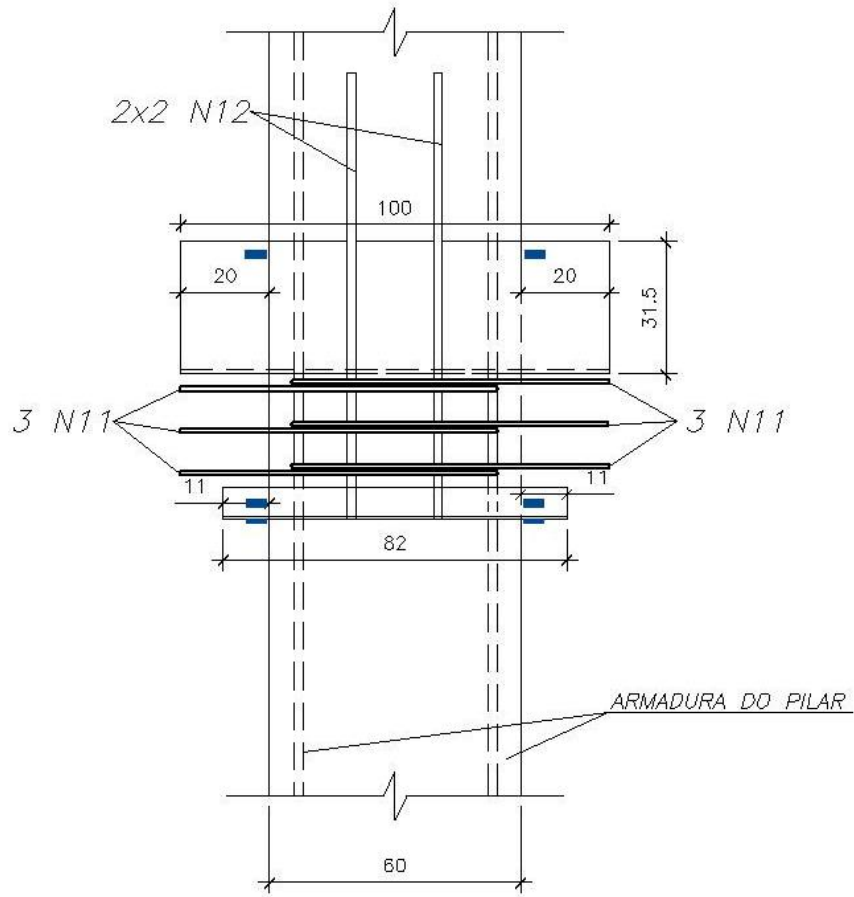

CONSOLO PERFIL U (X1)

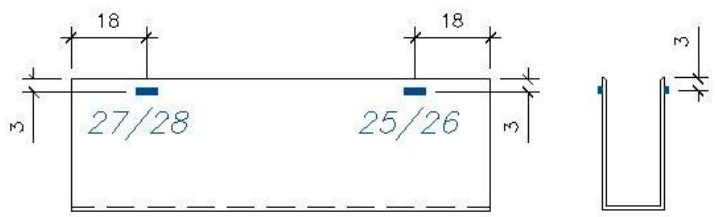

CANTONEIRAS (X2)

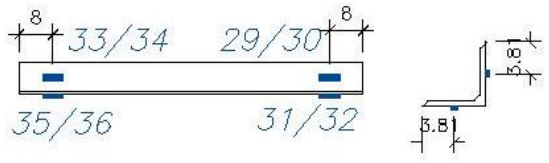

Figura 3.29 - Extensômetros dos perfis metálicos embutidos no pilar.

A etapa de instrumentação interna decorreu durante toda a construção do modelo, pois alguns elementos precisavam ser instrumentados antes da concretagem das vigas e outros 
somente após a execução das soldas na ligação, para evitar que perda do extensômetro devido à alta temperatura.

\subsubsection{Instrumentação externa}

A instrumentação externa é composta por transdutores de deslocamento, para a avaliação dos deslocamentos do modelo. $\mathrm{O}$ modelo esquemático da instrumentação externa é apresentado na Figura 3.30.

A Figura 3.30 mostra uma visão geral da instrumentação externa do modelo e dos transdutores posicionados abaixo do pilar e abaixo das vigas próximo aos apoios, e os transdutores posicionados na capa da laje junto ao pilar e abaixo das vigas também junto ao pilar.

Optou-se por adotar dois transdutores abaixo do pilar para avaliar a variação do deslocamento. Assim o valor do deslocamento no centro do pilar será a média dos deslocamentos dos transdutores.

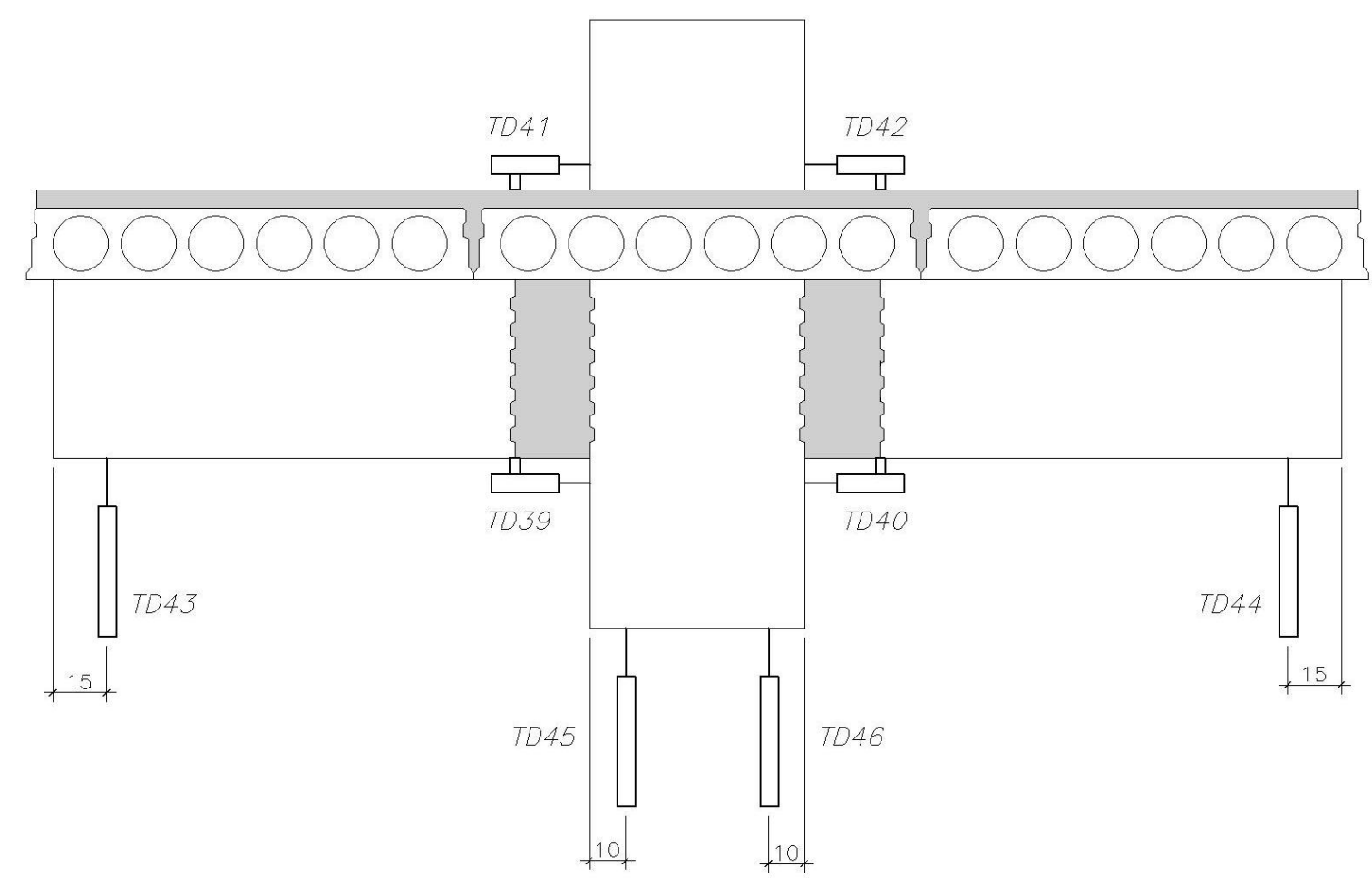

$\mathrm{TD}=$ Transdutor

Figura 3.30 - Ilustração da instrumentação externa. 
A numeração dos instrumentos de medição da Figura 3.30 indica o canal em que o instrumento foi colocado no equipamento de aquisição de dados.

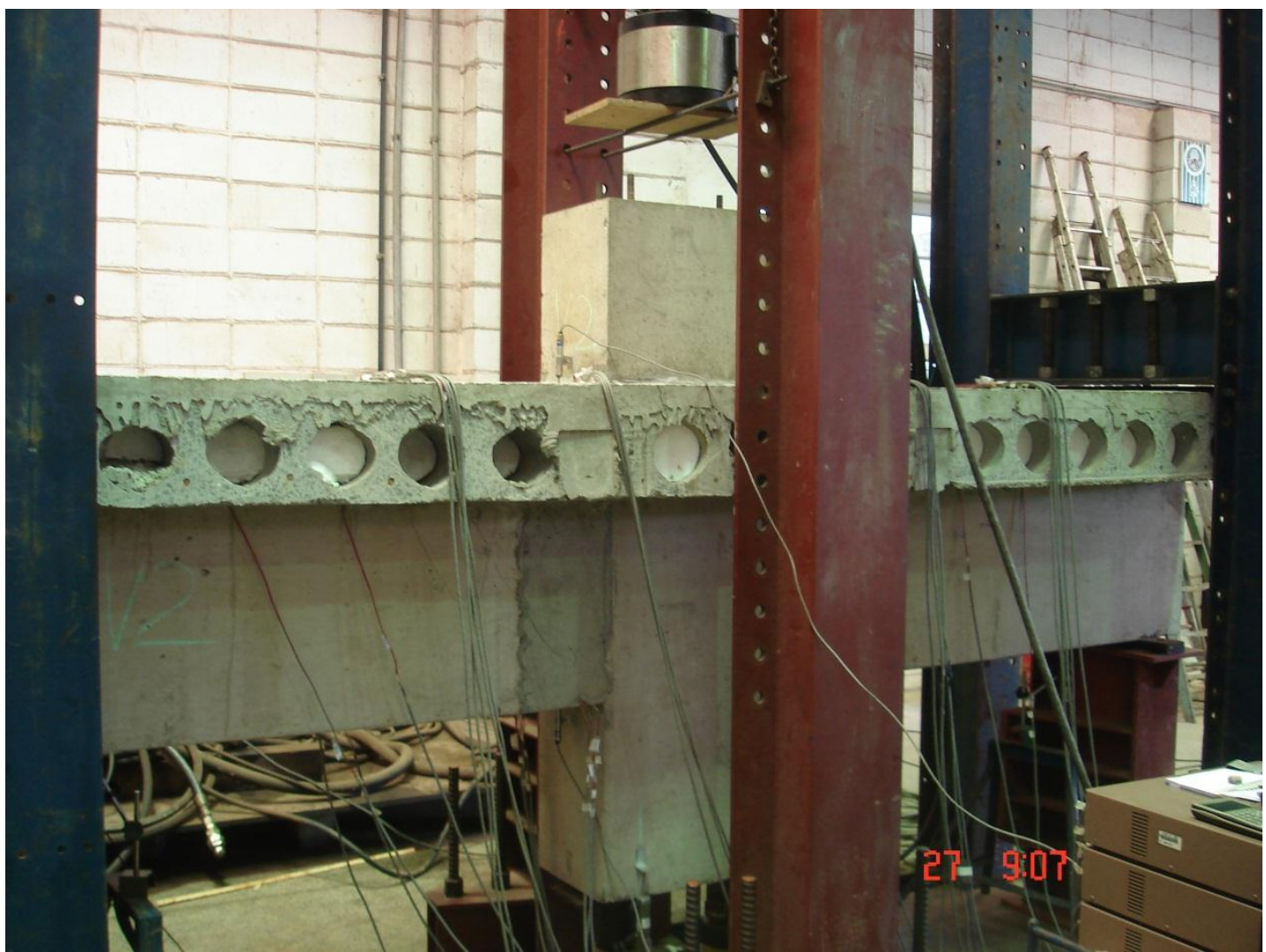

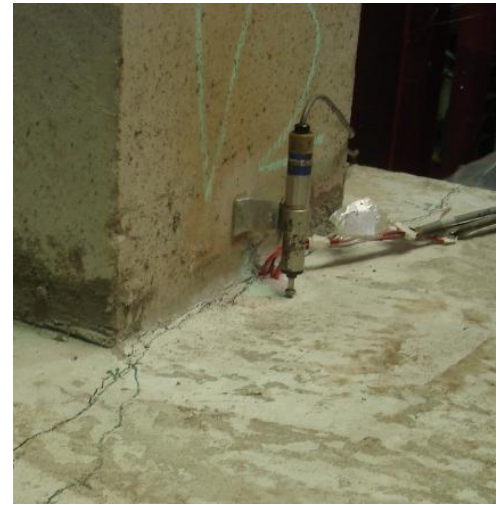

Transdutor na capa da laje

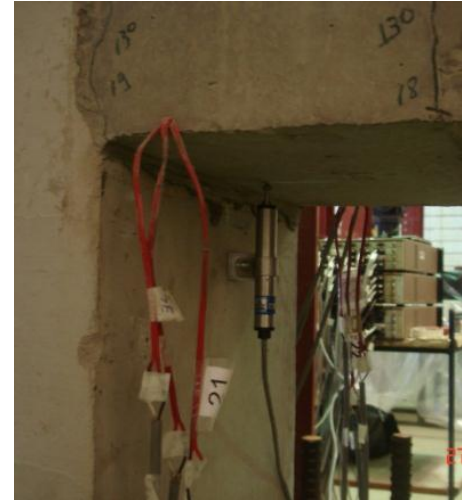

Transdutor abaixo da viga

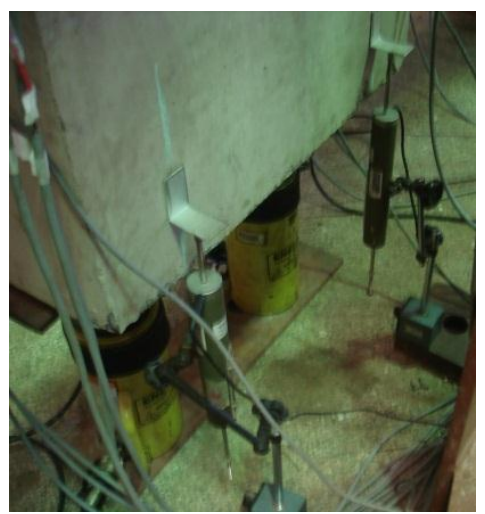

Transdutores abaixo do pilar

Figura 3.31 - Vista geral e detalhamento da instrumentação externa. 


\subsection{PROCEDIMENTO DO ENSAIO}

$\mathrm{O}$ ensaio foi realizado em duas etapas. Na primeira etapa utilizou-se um atuador servo controlado com capacidade de $500 \mathrm{kN}$ para aplicar carregamentos alternados de curta duração e com controle de deslocamentos sobre o pilar. Assim, as reações nos apoios das vigas resultavam em metade da força aplicada para cada lado. Essa etapa decorreu até atingir a capacidade máxima do atuador, e devido à elevada resistência do modelo, foi necessária a segunda etapa. Como o principal objetivo do ensaio era analisar a resistência da ligação ao momento negativo, na segunda etapa foi retirado o atuador e acrescentados sob o pilar dois macacos hidráulicos com capacidade de $500 \mathrm{kN}$ cada, totalizando em uma capacidade total de $1000 \mathrm{kN}$. Nesta etapa os carregamentos foram aplicados em apenas um sentido e com controle de força.

As Figuras 3.32 e 3.33 ilustram o esquema de ensaio para as duas etapas respectivamente. A Figura 3.34 mostra uma vista geral do modelo posicionado no pórtico de reação com o atuador conectado sobre o pilar e a Figura 3.35 apresenta os detalhes dos dispositivos de aplicação de força e de reação.

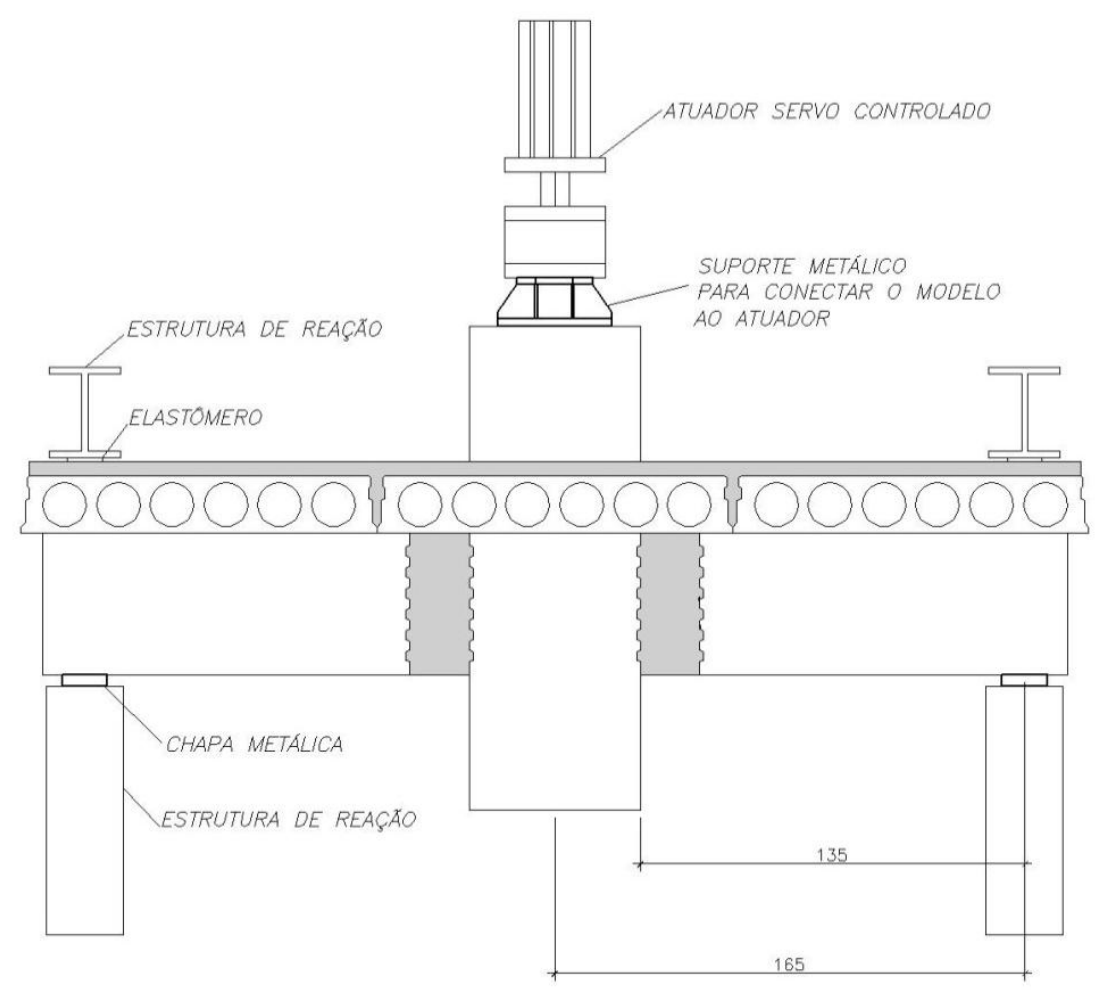

Figura 3.32 - Esquema de ensaio da primeira etapa. 


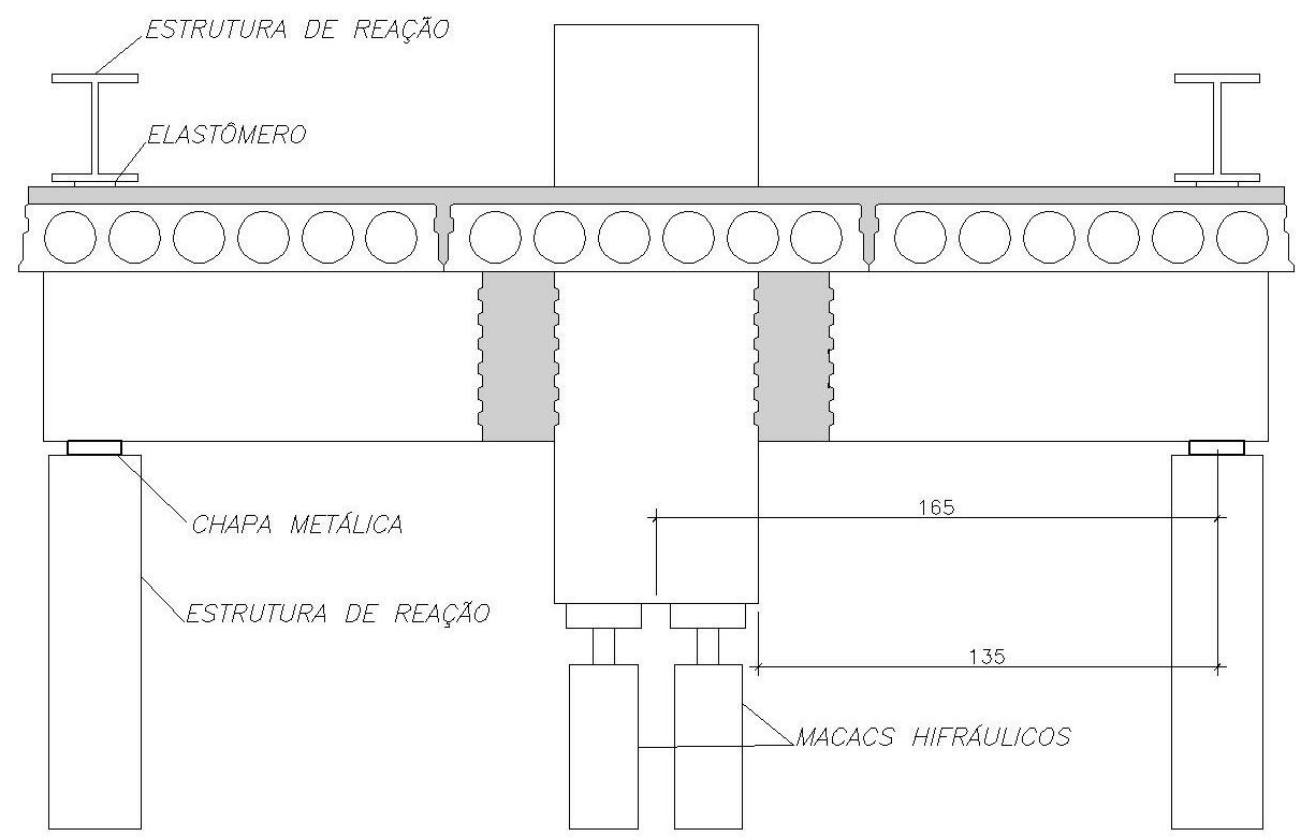

Figura 3.33 - Esquema de ensaio da segunda etapa.

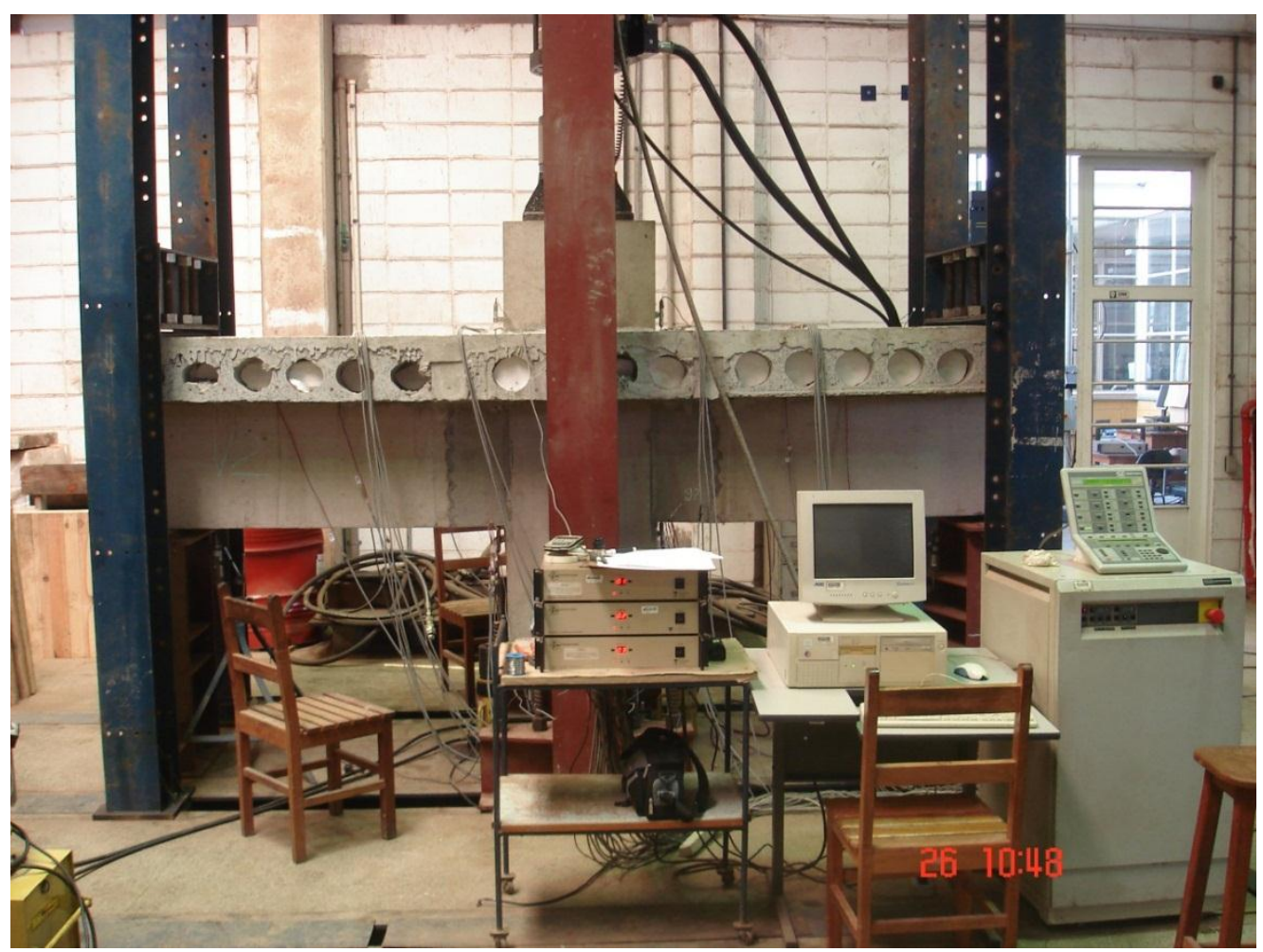

Figura 3.34 - Vista geral do esquema de ensaio. 


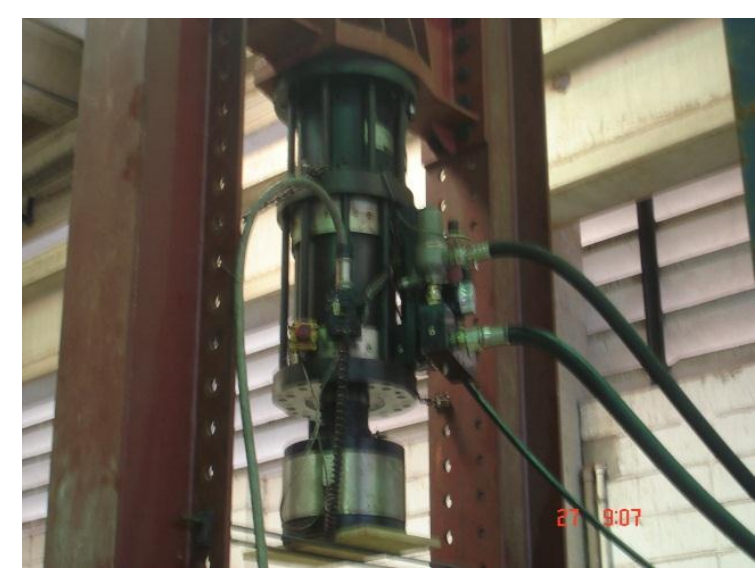

Atuador servo controlado

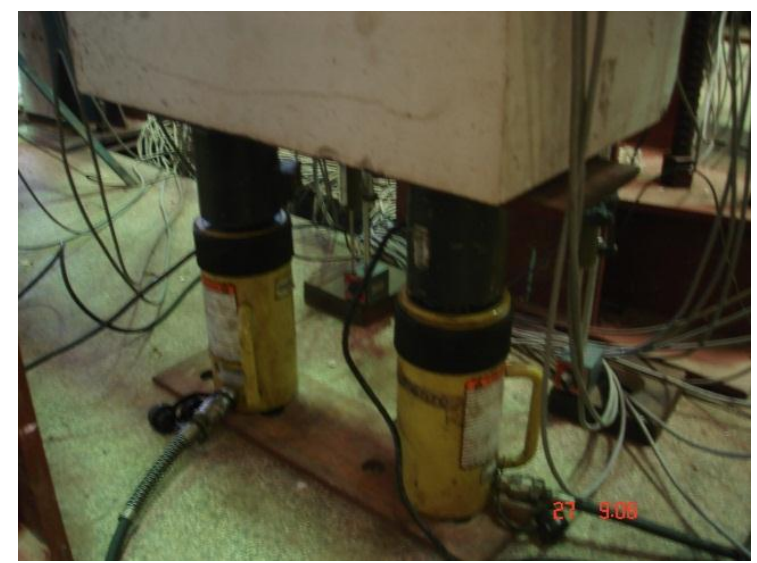

Macacos hidráulicos

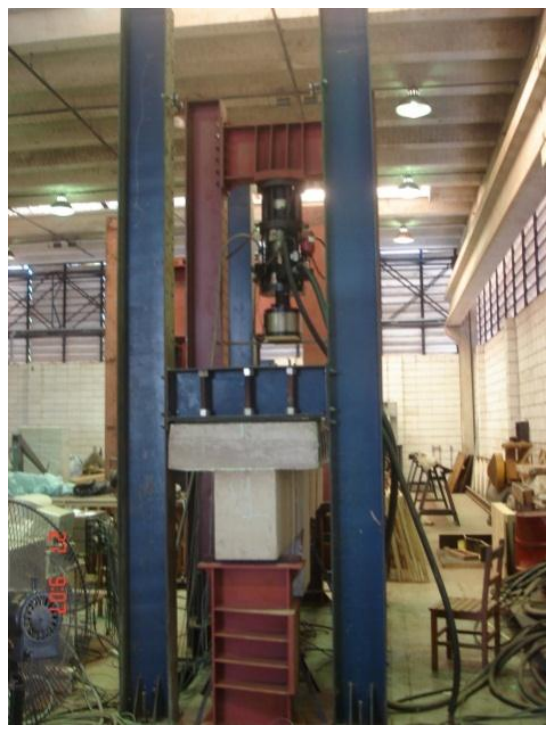

Estruturas de reação

Figura 3.35 - Dispositivos para aplicação de força e reação.

Antes de iniciar a primeira etapa do ensaio, foi aplicada uma força de $5 \%$ do valor da força de ruptura esperada para verificar o funcionamento dos equipamentos e elementos da instrumentação.

Na primeira etapa o carregamento alternado foi realizado através de 5 ciclos lentos e 10 ciclos para cada ciclo lento, resultando em 55 ciclos. A primeira etapa do ensaio visava representar o estado de utilização quanto ao momento negativo, porém seria possível atingir a ruptura na ligação resistente ao momento positivo. A resistência da ligação ao momento fletor negativo é de aproximadamente duas vezes a resistência da ligação resistente ao momento positivo. Portanto, o acréscimo de força nos ciclos que gera momento negativo foi de $20 \%$ da carga de ruptura para esta solicitação, enquanto que o acréscimo de força que gera momento positivo na ligação foi de $10 \%$ para esta solicitação. Assim, manteve-se nos ciclos a mesma aplicação de força para gerar momento negativo e positivo até $80 \%$ da resistência da ligação 
positiva para evitar a ruptura, e 50\% da resistência da ligação negativa, que atingiu a capacidade máxima do atuador. As marcações das fissuras foram feitas durante os 5 ciclos lentos.

$\mathrm{Na}$ segunda etapa, com os macacos hidráulicos sob o pilar, aplicou-se apenas o carregamento que gera momento negativo, para atingir a ruptura nesta situação. Foram realizados acréscimos de força da ordem de $20 \%$ da força estimada para a ruptura e procurouse manter cada acréscimo de carga aplicado por alguns instantes, suficiente para avaliar a abertura das fissuras.

A Figura 3.36 mostra os sentidos de aplicação dos carregamentos na primeira etapa e a Tabela 3.17 apresenta as forças estimadas para cada ciclo e o momento atuante para as duas etapas.

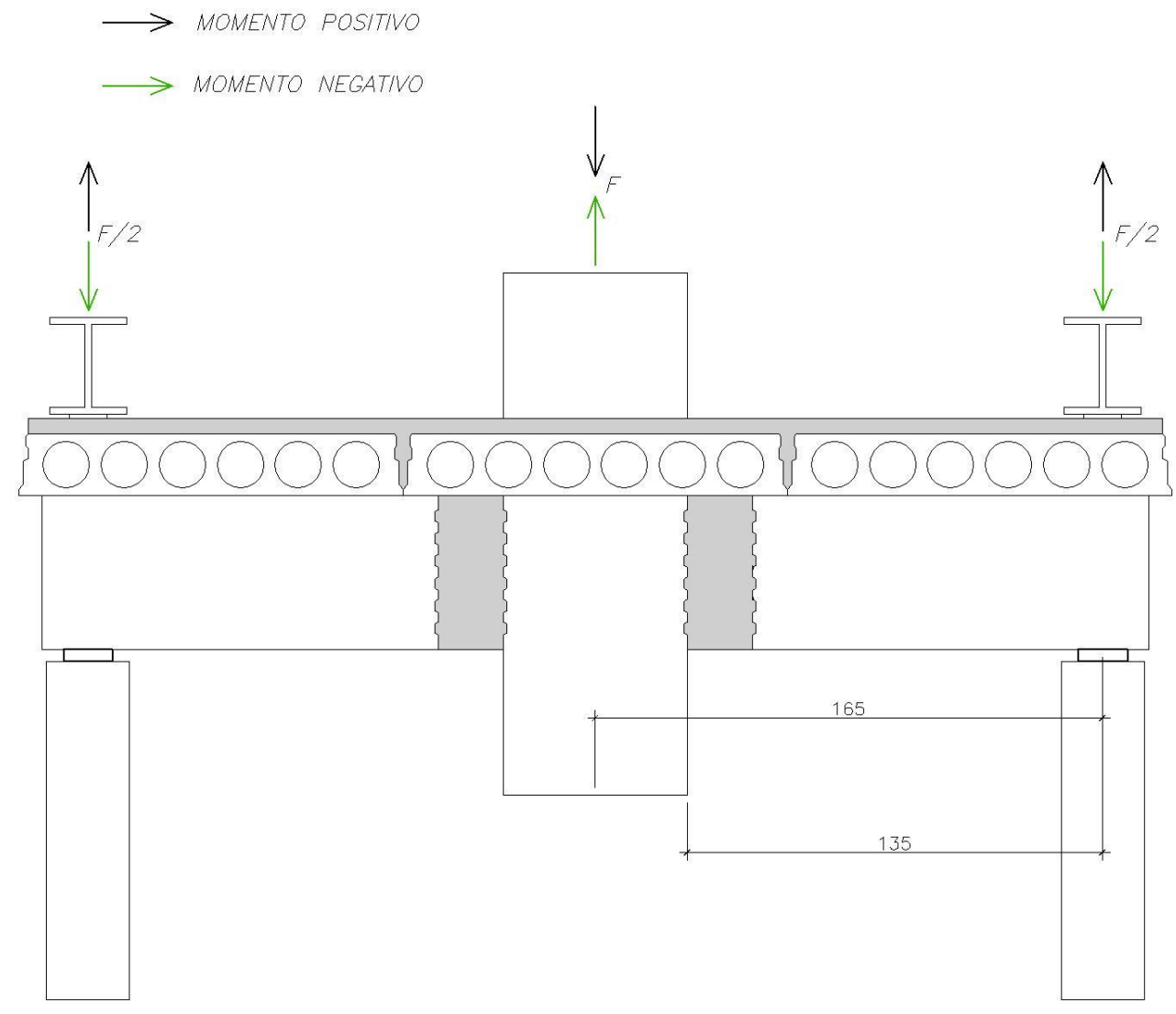

Figura 3.36 - Sentido das forças aplicadas na primeira etapa. 
Tabela 3.17 - Procedimento previsto de aplicação dos carregamentos nas duas etapas.

Ligação Positiva: $\mathbf{- 4 2 6 , 7 0 ~ k N ~ E s c o a m e n t o ~ d a s ~ c a n t o n e i r a s ~ m e t a ́ l i c a s ~}$

Ligação Negativa: $860,00 \mathbf{~ k N}$ Escoamento da armadura negativa soldada ao perfil tubular da viga

\begin{tabular}{|c|c|c|c|c|c|}
\hline Etapas & $\begin{array}{c}\text { Força M+ } \\
(\mathbf{k N})\end{array}$ & $\begin{array}{c}\text { Força M- } \\
(\mathbf{k N})\end{array}$ & $\%$ & $\begin{array}{c}\text { Momentos } \\
(\mathbf{k N m})\end{array}$ & Comentários \\
\hline \multirow{6}{*}{ Primeira etapa } & $-21,3$ & & $-5 \%$ & 14,38 & $\begin{array}{l}\text { Escorvamento (Verificar } \\
\text { funcionamento dos }\end{array}$ \\
\hline & $-85,3$ & 86,0 & $-20 \%$ & $\begin{array}{c}-58,05 \\
57,58\end{array}$ & $\begin{array}{l}01 \text { Ciclo lento com } \mathrm{V}=0,02 \\
\mathrm{~mm} / \mathrm{s} \text { e } 10 \text { ciclos rápidos com } \\
\mathrm{V}=0,10 \mathrm{~mm} / \mathrm{s}\end{array}$ \\
\hline & -170 & 172,0 & $-40 \%$ & $\begin{array}{l}-116,10 \\
114,75\end{array}$ & $\begin{array}{l}01 \text { Ciclo lento com } \mathrm{V}=0,02 \\
\mathrm{~mm} / \mathrm{s} \text { e } 10 \text { ciclos rápidos com } \\
\mathrm{V}=0,10 \mathrm{~mm} / \mathrm{s}\end{array}$ \\
\hline & -256 & 258,0 & $\begin{array}{l}30 \% \\
-60 \%\end{array}$ & $\begin{array}{r}-174,15 \\
172,80\end{array}$ & $\begin{array}{l}01 \text { Ciclo lento com } \mathrm{V}=0,01 \\
\mathrm{~mm} / \mathrm{s} \text { e } 10 \text { ciclos rápidos com } \\
\mathrm{V}=0,10 \mathrm{~mm} / \mathrm{s}\end{array}$ \\
\hline & -341 & 344,0 & $\begin{array}{l}40 \% \\
-80 \%\end{array}$ & $\begin{array}{l}-232,20 \\
230,18\end{array}$ & $\begin{array}{l}01 \text { Ciclo lento com } \mathrm{V}=0,01 \\
\mathrm{~mm} / \mathrm{s} \text { e } 10 \text { ciclos rápidos com } \\
\mathrm{V}=0,10 \mathrm{~mm} / \mathrm{s}\end{array}$ \\
\hline & & 430,0 & $50 \%$ & $-290,25$ & $\begin{array}{l}\text { Capacidade máxima do } \\
\text { atuador de puxar o modelo }\end{array}$ \\
\hline \multirow{5}{*}{ Segunda etapa } & & 172,0 & $20 \%$ & $-116,10$ & \\
\hline & & 344,0 & $40 \%$ & $-232,20$ & \\
\hline & & 516,0 & $60 \%$ & $-348,30$ & \\
\hline & & 688,0 & $80 \%$ & $-464,40$ & \\
\hline & & 860,0 & $100 \%$ & $-580,50$ & $\begin{array}{l}\text { Ruptura utilizando } 02 \text { macacos } \\
\text { hidráulicos com capacidade } \\
\text { para } 500 \mathrm{kN} \text { cada }\end{array}$ \\
\hline
\end{tabular}

A previsão de carregamento para o ensaio foi elaborada com base na hipótese da ruptura ocorrer com escoamento da armadura negativa das vigas. 


\section{ANÁLISE DOS RESULTADOS}

\subsection{CONSIDERAÇÕES INICIAIS}

Este capítulo apresenta uma análise do processo de desenvolvimento da ligação e os resultados do ensaio experimental do modelo proposto. São apresentados os resultados de resistência e deformação dos elementos constituintes da ligação que foram instrumentados, e esses resultados são comparados com a análise dos mecanismos resistentes da ligação.

Neste capítulo estão apresentados os principais gráficos para a análise dos resultados.

\subsection{AVALIAÇÃO DA LIGAÇÃO REALIZADA}

Não ocorreram grandes dificuldades para a montagem das armaduras dos elementos pré-moldados com os dispositivos metálicos, considerando as dimensões dos perfis. Para elementos com menor taxa de armadura e com perfis mais leves, pode-se observar uma boa produtividade para a construção das vigas e pilares realizando a solda das barras de aço nos dentes e consolo metálicos previamente à montagem da armadura. No caso das vigas não houve contratempos com as formas. No caso do pilar a execução também foi relativamente fácil. Após a desforma dos elementos pré-moldados a maior dificuldade na montagem do modelo foi devido às tolerâncias, pois os componentes da ligação precisam ser soldados e para isso não pode haver espaços muito abertos entre eles. Este problema pode gerar perda de produtividade na montagem da estrutura em campo. 
Quanto à solda da ligação, o modelo permitiu realizar este serviço com grande facilidade e rapidez na junção do consolo e do dente devido à solda ser realizada na horizontal e com o eletrodo no sentido de cima para baixo, possibilitando maior qualidade da solda de campo. Já na solda das armaduras positivas das vigas nas cantoneiras embutidas no pilar, o trabalho apresentou certa dificuldade, pois a posição do soldador durante o trabalho é desprivilegiada e também, como existe alta taxa de armadura na ligação, há dificuldade de posicionar o eletrodo. $\mathrm{O}$ ganho de produtividade na solda da ligação resistente ao momento negativo pode ser perdido na solda da ligação resistente ao momento positivo.

\subsection{RESULTADOS EXPERIMENTAIS}

O ensaio foi realizado em duas etapas, sendo a primeira o ensaio cíclico com o atuador servo hidráulico e a segunda com os macacos hidráulicos locados abaixo do pilar para forçar a ruptura com momento fletor negativo.

\subsubsection{Ensaio cíclico da primeira etapa}

Nesta etapa procurou-se analisar o comportamento em serviço da ligação com inversão dos carregamentos, gerando momentos positivos e negativos podendo observar os mecanismos resistentes e comparar com os resultados obtidos na caracterização dos materiais utilizados.

Os valores dos momentos fletores foram calculados pela força de reação gerada no apoio das vigas, esquema apresentado na Figura 3.34, multiplicada pela distância do ponto de aplicação dessa força até a posição do extensômetro analisado, conforme a seguinte equação.

$$
M=\frac{F_{p}}{2} \cdot d_{e}
$$

Onde:

$\boldsymbol{M} \quad$ = Momento fletor na seção do extensômetro analisado

$\boldsymbol{F}_{\boldsymbol{p}} \quad=$ Força aplicada no pilar

$\boldsymbol{d}_{\boldsymbol{e}}=$ Distância do apoio da viga até a seção do extensômetro analisado 
O gráfico da Figura 4.1 apresenta a média das medidas de deformação dos extensômetros locados no consolo metálico, próximo ao pilar, nas duas ligações, em função da força aplicada no pilar pelo atuador.

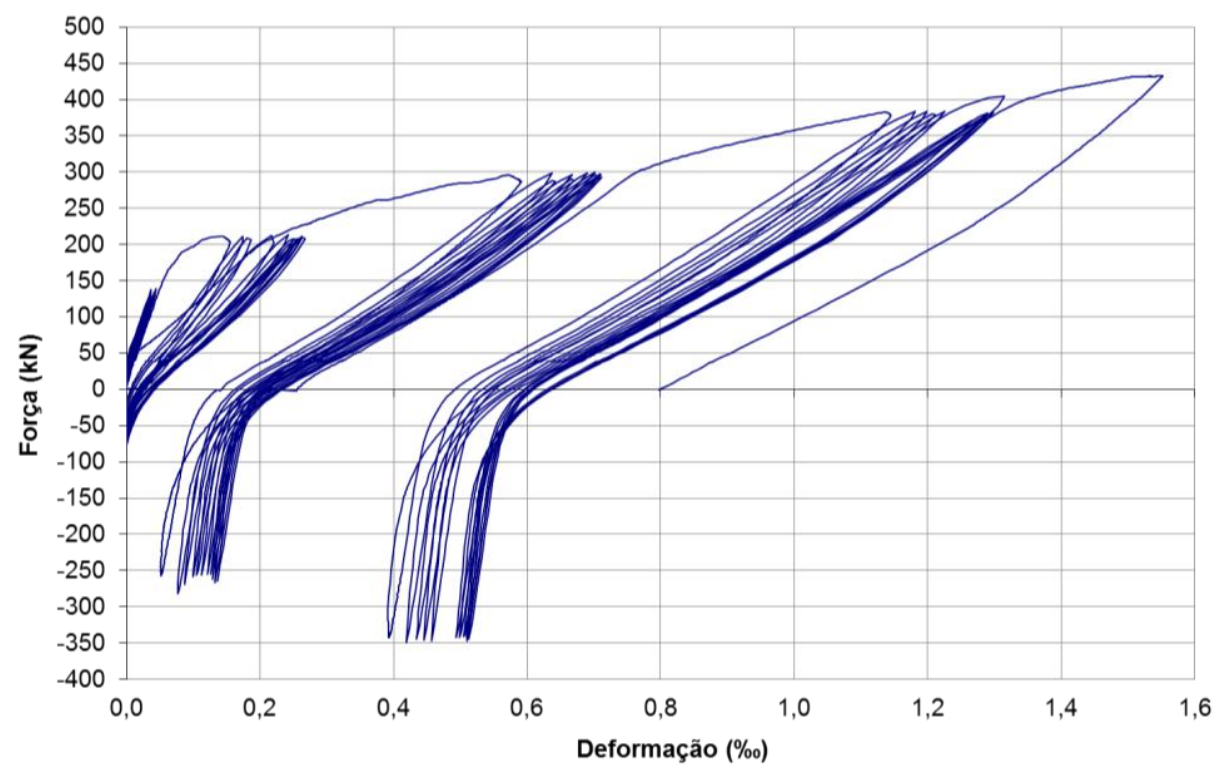

Figura 4.1 - Média das medidas de deformação no consolo metálico do pilar (extensômetros $25,26,27$ e 28$)$.

Neste gráfico estão apresentados os 4 ciclos lentos e os 10 ciclos rápidos para cada ciclo lento e uma aplicação de carga lenta até a máxima capacidade do atuador. O espaçamento entre os ciclos do gráfico indica a deformação residual no elemento metálico que ao final do ensaio cíclico foi de $0,80 \%$.

Na Figura 4.2 a seguir está apresentada a envoltória dos valores de deformação de tração do perfil embutido no pilar. 


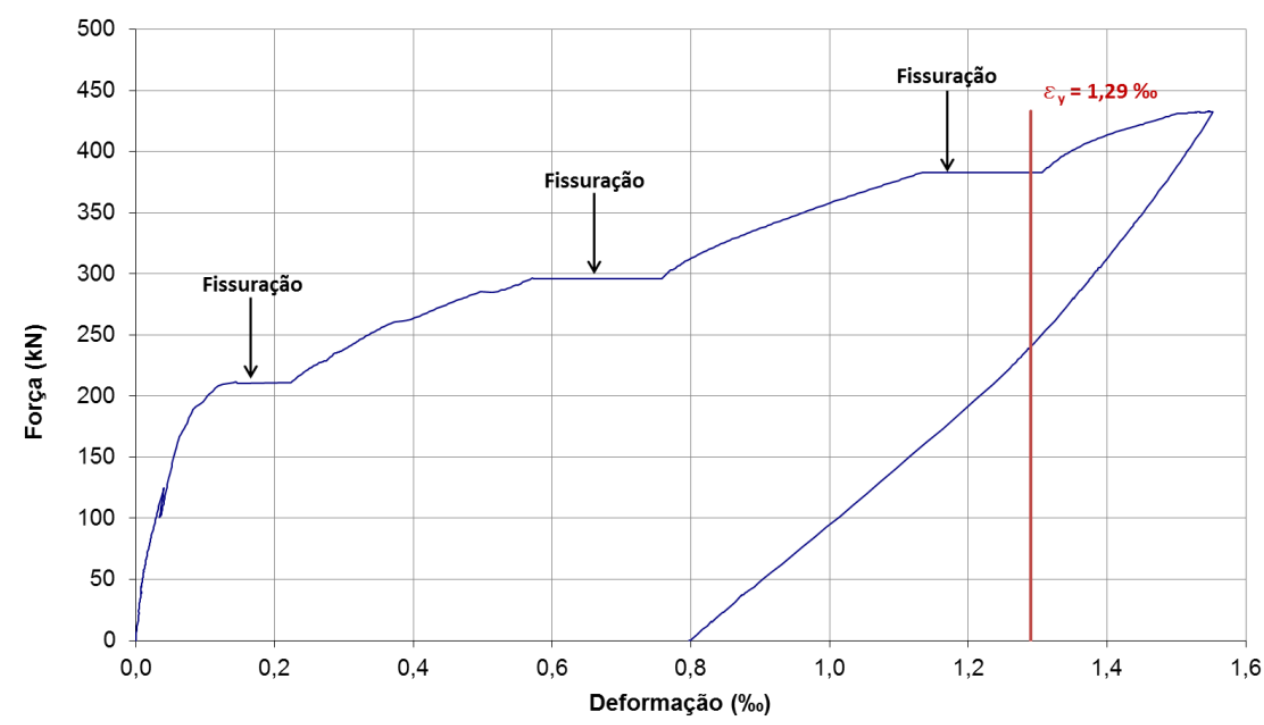

Figura 4.2 - Envoltória da curva força aplicada no pilar por deformação do consolo metálico.

O momento negativo máximo na seção dos extensômetros em análise foi de -292,15 kN.m, tendo sido medida uma deformação de 1,55\% no perfil metálico do consolo. Esse valor é maior que a deformação correspondente ao início do escoamento (1,29\%o) obtida nos ensaios de caracterização e, para essa deformação, o momento fletor negativo foi aproximadamente $-225,5$ kN.m. Os patamares indicados no gráfico são devidos à fissuração durante os ciclos de carregamento.

Os gráficos da Figura 4.3 e 4.4 a seguir apresentam as médias dos valores de deformação em função da força aplicada no pilar, medidos nos dentes metálicos das duas vigas, nas seções próximas ao pilar e à viga pré-moldada, quando aplicado momento negativo no ensaio cíclico. 


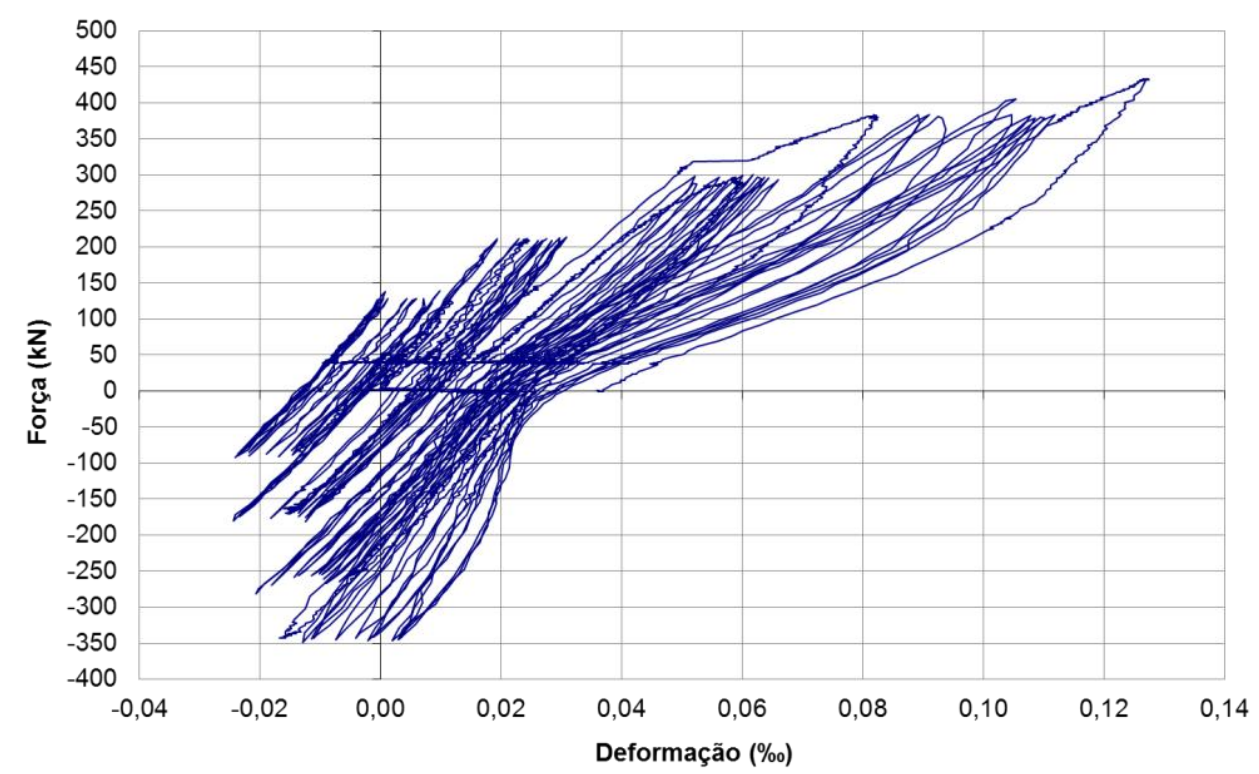

Figura 4.3 - Curva força aplicada-deformação do dente metálico na seção próxima à viga pré-moldada (extensômetros 11 e 23).

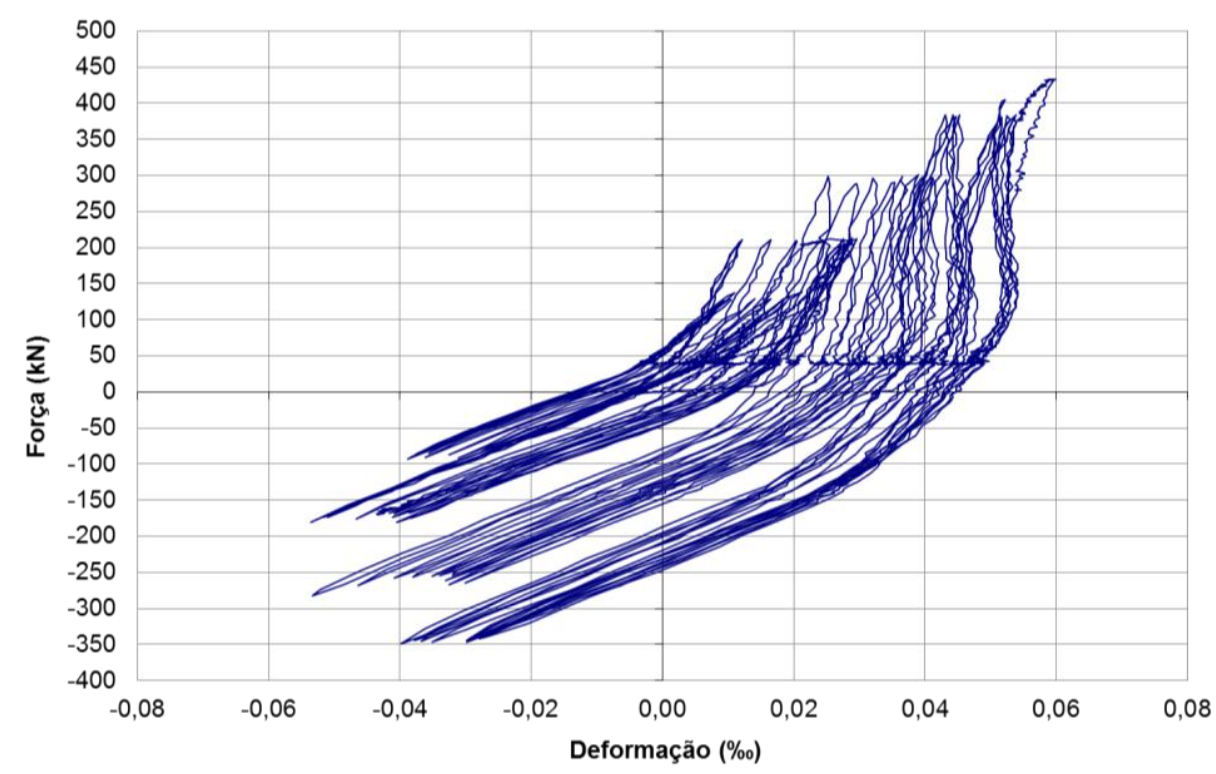

Figura 4.4 - Curva força aplicada-deformação do dente metálico na seção próxima ao pilar (extensômetros 12 e 24).

As deformações medidas pelo extensômetro locado no dente metálico, próximo à face do pilar foram muito baixas, atingindo nesta etapa do ensaio 0,06\%, enquanto que na mesma seção as deformações no consolo metálico foram altas, chegando ao escoamento. Isso ocorre devido a uma falha no modelo de ligação, pois não existe uma mesa superior no perfil do consolo soldada à mesa do perfil tubular embutido na viga pré-moldada, assim na seção 
próxima à face do pilar, apenas o consolo metálico resiste à flexão. Essa falha pode ser vista na Figura 4.5.

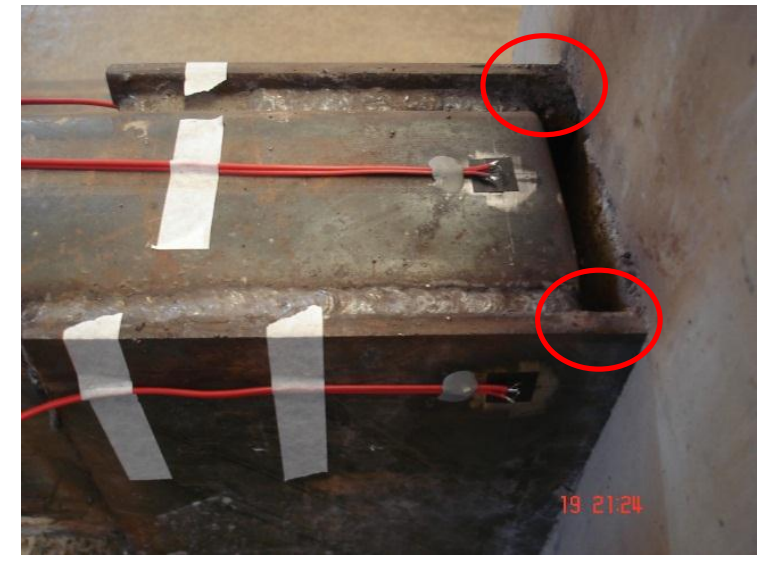

Figura 4.5 - Região de escoamento do consolo metálico.

Já na seção do dente metálico próxima à viga pré-moldada, a deformação de $0,13 \%$ o foi maior do que na seção próxima à face do pilar, devido à transmissão das tensões pela solda entre os elementos metálicos.

O gráfico da Figura 4.6 apresenta a média das deformações ocorridas nas armaduras negativas soldadas no dente metálico, na seção distante de $55,50 \mathrm{~cm}$ da face do pilar.

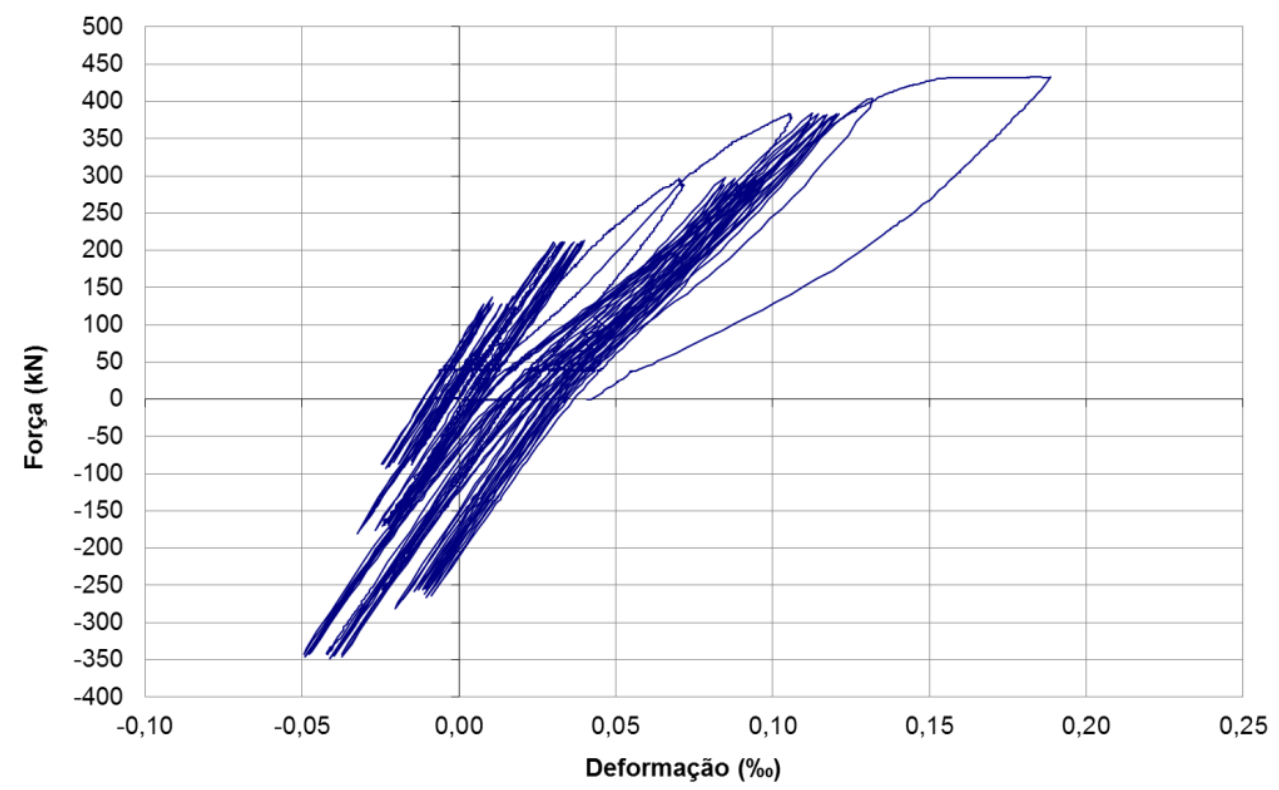

Figura 4.6 - Curva força aplicada-deformação das armaduras negativas (extensômetros 1, 2, 14 e 15).

O momento negativo máximo nessa seção transversal foi de 172,12 kN.m, tendo sido medida uma deformação de 0,189\%o. Dos ensaios de caracterização das armaduras, para as barras de bitola de 25,0 mm foi obtida uma resistência média ao escoamento de 568,66 MPa e 
módulo de elasticidade tomado como $200 \mathrm{GPa}$, pela Lei de Hooke, pode-se obter o valor de deformação do início de escoamento, que é de 2,84\%, portanto, na primeira etapa do ensaio a armadura negativa não atingiu o escoamento.

$\mathrm{Na}$ inversão do carregamento foram medidas as deformações nas cantoneiras embutidas no pilar e nas armaduras positivas soldadas nas cantoneiras.

No gráfico da Figura 4.7 está apresentada a curva média das deformações nas cantoneiras em função da força aplicada no pilar. Foram calculadas as médias das deformações medidas nas duas cantoneiras, nas duas ligações, e nas duas abas por serem cantoneiras de abas iguais e as armaduras positivas estarem soldadas simetricamente nas abas. Portanto, no gráfico está representada a média dos valores medidos pelos extensômetros 30, 31, 32, 33, 34, 35 e 36. O extensômetro 29 faz parte do conjunto, mas foi perdido.

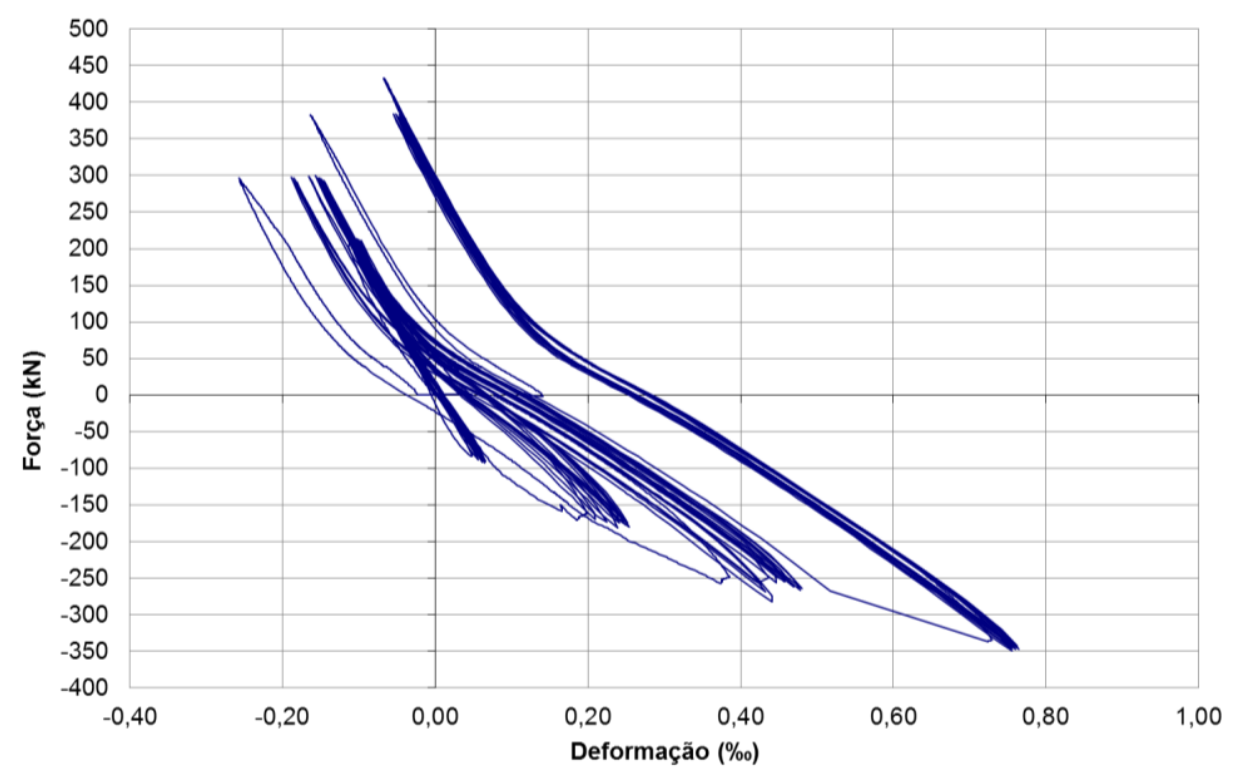

Figura 4.7 - Curva força aplicada-deformação das cantoneiras embutidas no pilar (extensômetros 30, 31, 32, 33, 34, 35 e 36).

A força máxima aplicada no pilar para solicitar a ligação ao momento positivo foi de $348,96 \mathrm{kN}$, cerca de $80 \%$ da força máxima aplicada para solicitar a ligação ao momento negativo, pois a resistência da ligação ao momento negativo é maior e o interesse do estudo é de apenas analisar o comportamento em serviço da ligação positiva e que a ruptura ocorresse na ligação negativa. O momento positivo máximo na ligação foi de $235,55 \mathrm{kNm}$ e a cantoneira sofreu uma deformação de 0,76 \%. Na caracterização do material da cantoneira a deformação média do início do escoamento é de 1,52 \%, portanto durante o ensaio do modelo as cantoneiras não chegaram a escoar. 
Os gráficos das Figuras 4.8 e 4.9 apresentam as curvas das médias das deformações em função da força aplicada no pilar para as armaduras positivas, sendo na seção da ligação próxima às cantoneiras, medidas pelos extensômetros 9, 10, 21 e 22, e na seção da viga prémoldada, medidas pelos extensômetros $3,4,15$ e 16, respectivamente.

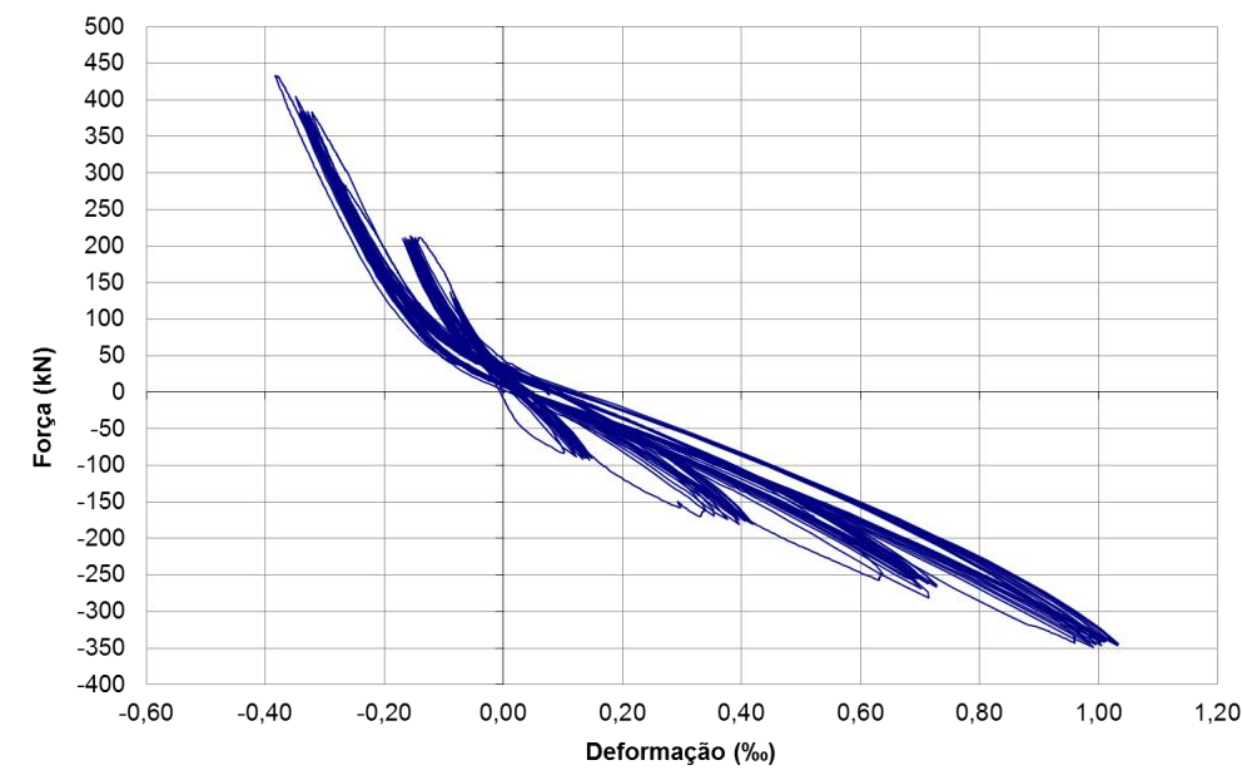

Figura 4.8 - Curva força aplicada-deformação das armaduras positivas na ligação (extensômetros 9, 10, 21 e 22).

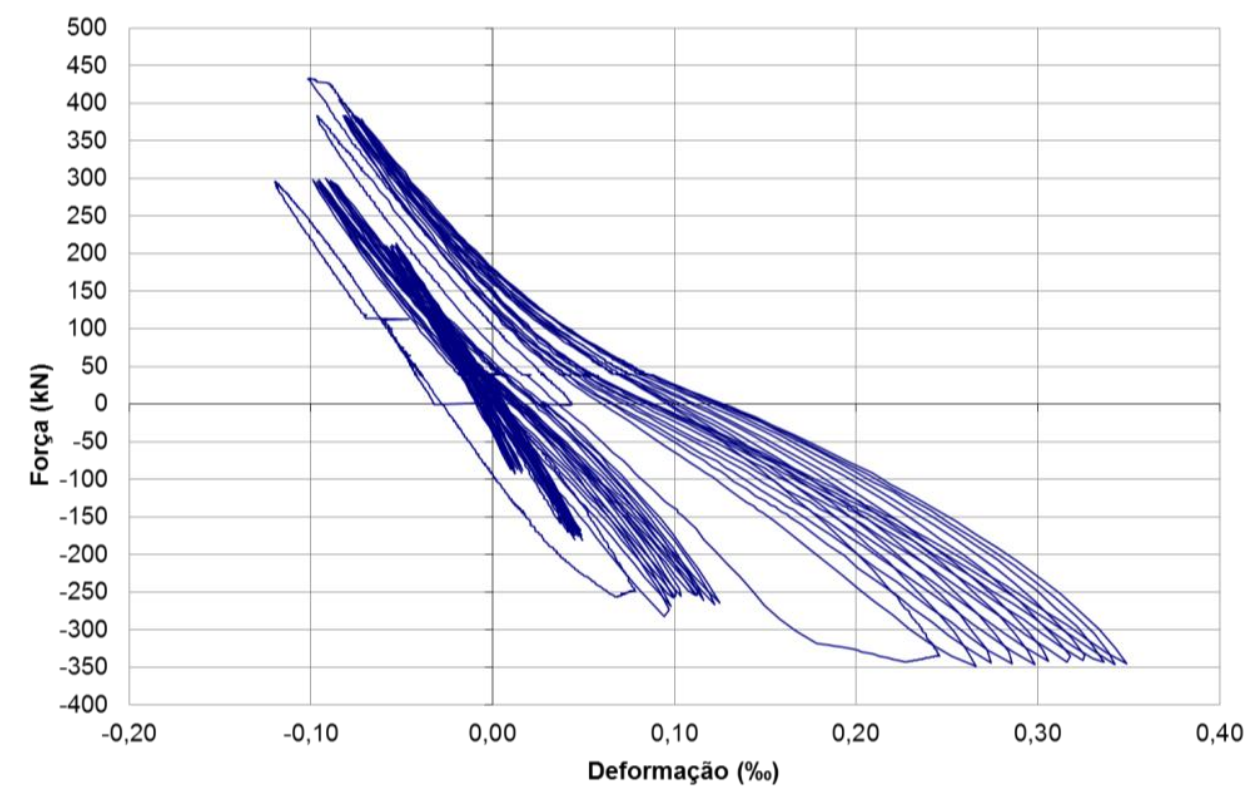

Figura 4.9 - Curva força aplicada-deformação das armaduras positivas na viga prémoldada (extensômetros 3, 4, 15 e 16).

O momento máximo na seção da ligação foi de 212,87 kNm, e a deformação máxima foi $1,03 \%$. A deformação média do início do escoamento obtida pelos ensaios de 
caracterização das barras de bitola igual a $25 \mathrm{~mm}$ foi de $2,84 \%$, portanto a armadura positiva não chegou a escoar.

Na seção da viga o momento máximo aplicado foi de $139,58 \mathrm{kNm}$ e a deformação atingida foi de $0,35 \%$.

Analisando a fissuração para o momento negativo, devido à concentração de tensões de tração na capa, esta fissurou com a aplicação de força da ordem de $210 \mathrm{kN}$, e as fissuras distribuíram-se de forma simétrica no modelo e paralelas à face do pilar, conforme Figura 4.10.
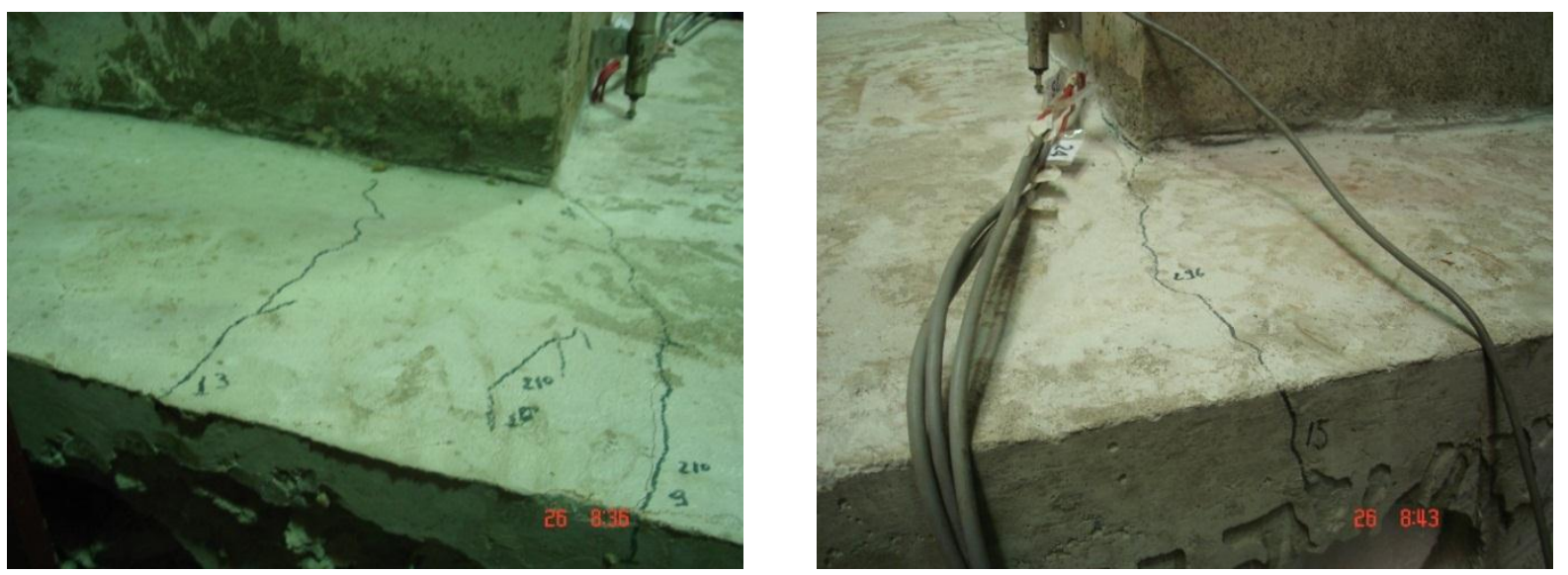

Figura 4.10 - Fissuração da capa da laje durante o ensaio da primeira etapa.

Com o aumento da carga as fissuras devidas ao momento negativo se propagaram por toda a altura da laje, aparecendo fissuras na superfície inferior com a aplicação de força de aproximadamente $313 \mathrm{kN}$, apresentado na Figura 4.11. Portanto ocorreu a ruptura do painel alveolar já nesta etapa do ensaio.

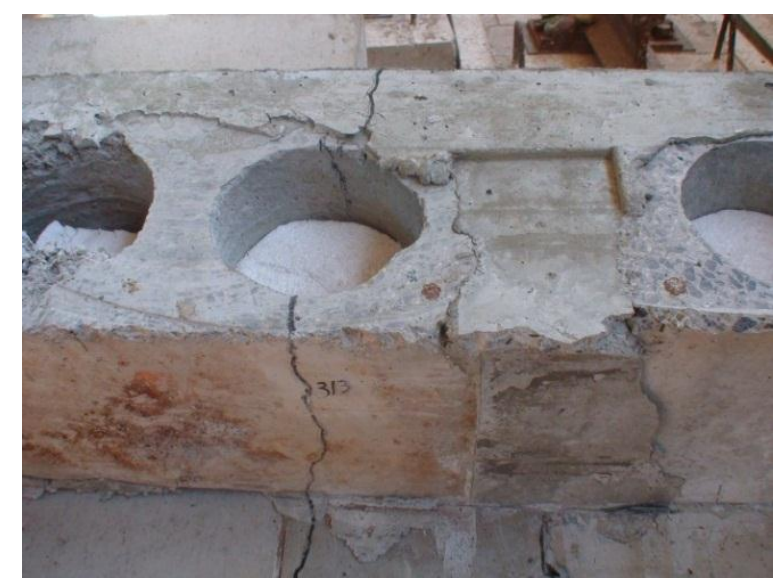

Figura 4.11 - Fissuração da superfície inferior da laje durante o ensaio da primeira etapa. 
As etapas que ocorrem as aberturas das fissuras podem ser vistas no gráfico da Figura 4.2.

Quando solicitada ao momento positivo a ligação fissurou na região das chaves de cisalhamento junto ao pilar e a viga, acompanhando o desenho das chaves, com a aplicação de força da ordem de $130 \mathrm{kN}$, conforme Figura 4.12.
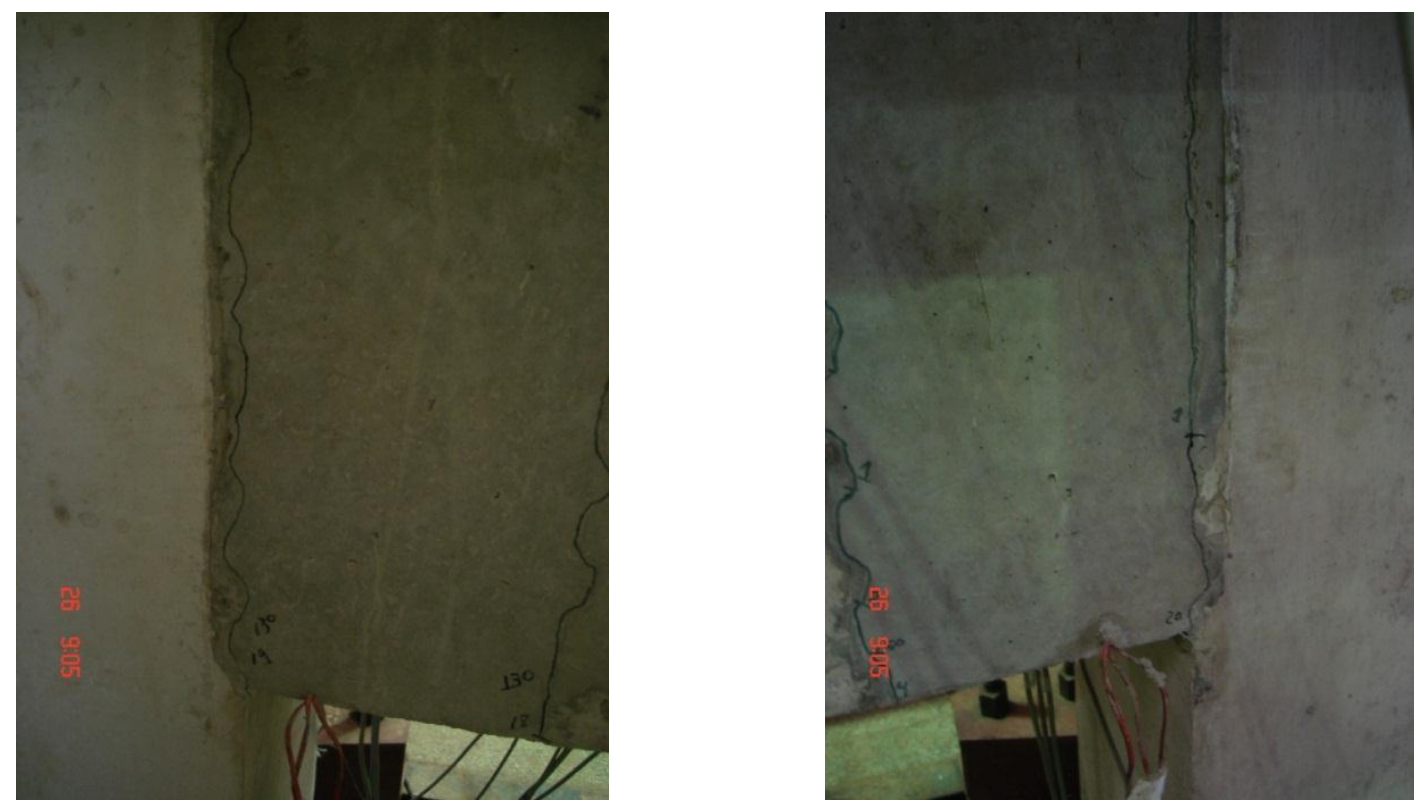

Figura 4.12 - Fissuração das ligações durante a primeira etapa do ensaio.

Com o acréscimo de força as fissuras de momento positivo na ligação se estenderam até a altura total da viga.

O diagrama da Figura 4.13 apresenta o deslocamento relativo entre o pilar e os apoios, tomando como valores a média dos transdutores TD45 e TD46 posicionados junto aos apoios, subtraída da média dos transdutores TD43 e TD44 posicionados abaixo do pilar, conforme Figura 3.24 apresentada no capítulo anterior. 


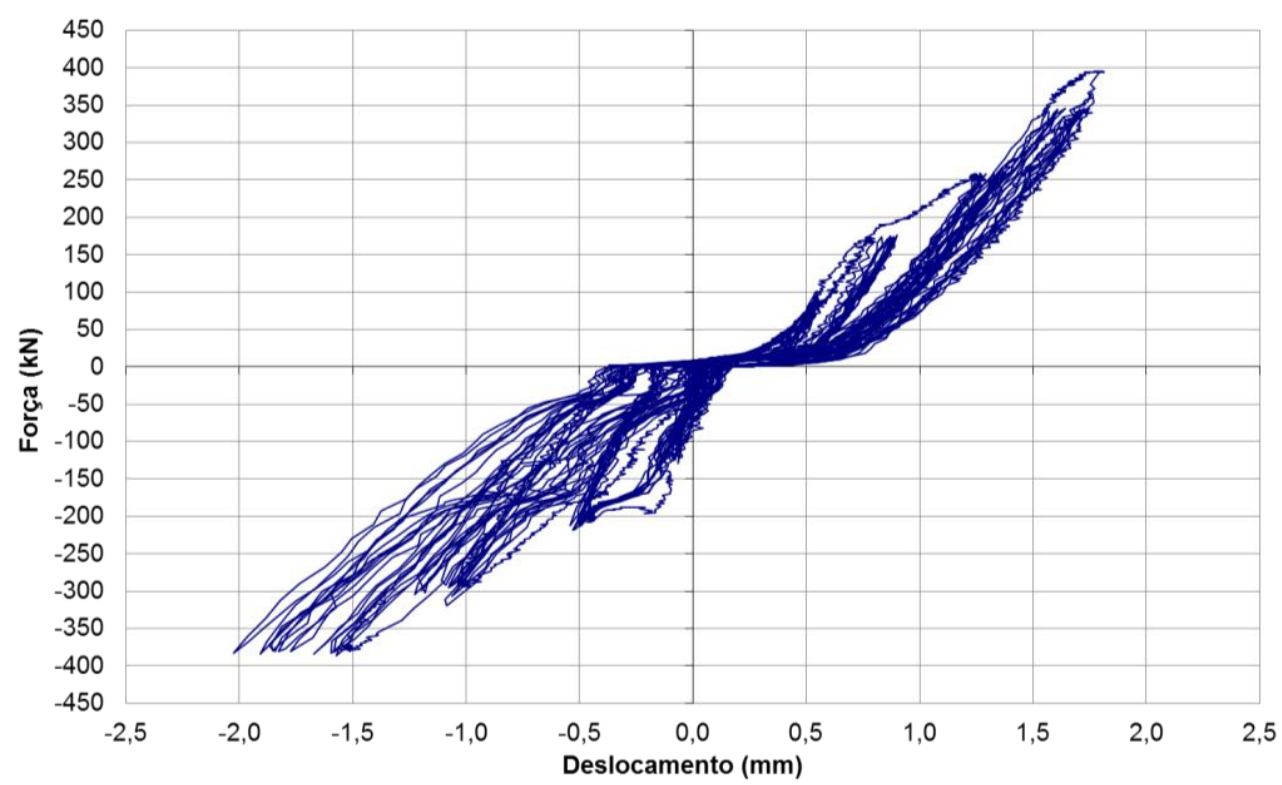

Figura 4.13 - Deslocamento relativo do pilar e os apoios.

Nota-se que os deslocamentos foram muito próximos para as forças negativas (momentos positivos) e forças positivas (momentos negativos), e observa-se também o incremento desses deslocamentos para cada ciclo de carga em ambos os sentidos. Isso indica que para o carregamento de até aproximadamente $400 \mathrm{kN}$ o comportamento da ligação é semelhante para momentos negativos e positivos.

\subsubsection{Ensaio monotônico da segunda etapa}

Durante o ensaio, a ruptura do modelo foi forçada a ocorrer com momento negativo na ligação, como descrito no capítulo anterior. Foram utilizados os macacos hidráulicos para gerar a carga de ruptura que provesse o escoamento por tração da armadura negativa ou dos perfis metálicos, sendo os dentes das vigas e o consolo do pilar.

A ruptura da ligação ocorreu por escoamento do consolo junto ao pilar, na região da folga do encaixe do dente no consolo conforme apresentado na Figura 4.5. Nessa área não foi possível soldar os perfis metálicos. A força máxima aplicada sob o pilar no momento da ruptura foi de $776,00 \mathrm{kN}$.

A ruptura ocorreu com o momento negativo atuante de $-523,54$ kN.m. O gráfico da Figura 4.14 apresenta as deformações medidas pelos extensômetros fixados próximos à face do pilar no consolo metálico, em relação à soma das forças aplicadas pelos dois macacos hidráulicos. 


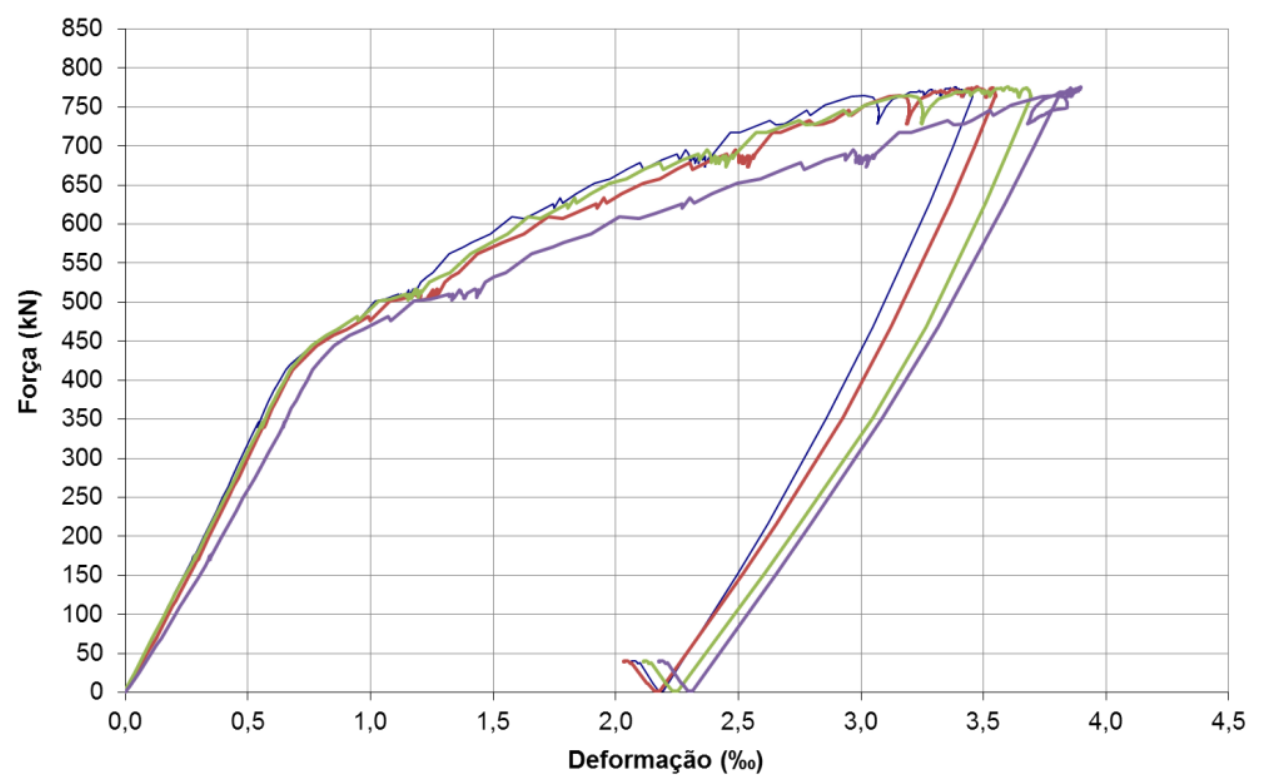

Figura 4.14 - Curva força no pilar-deformação do consolo metálico quando aplicado momento negativo (extensômetros 25, 26, 27 e 28).

Na Figura 4.15 está apresentado o gráfico da média dos valores de deformação considerando todos os extensômetros fixados no consolo metálico nas duas ligações viga-pilar do modelo. A deformação máxima do consolo foi de 3,63\%.

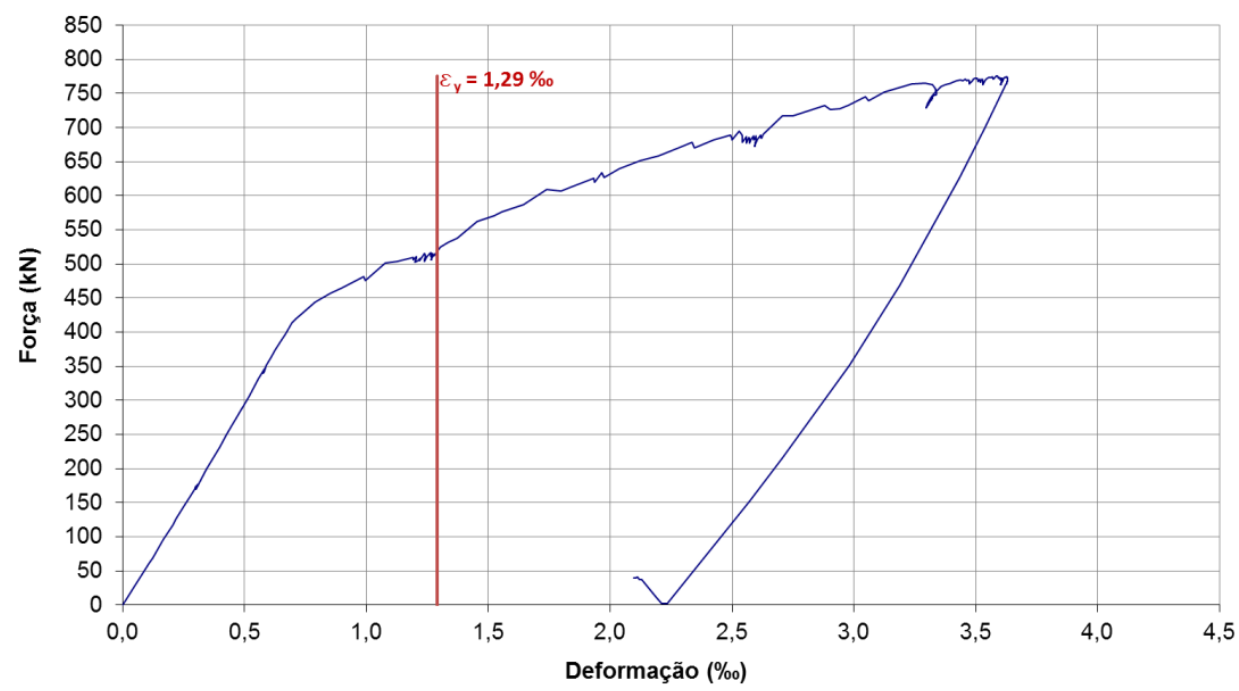

Figura 4.15 - Curva força no pilar-deformação do consolo - média das deformações medidas pelos extensômetros $25,26,27$ e 28 .

As curvas das Figuras 4.16 e 4.17 apresentam o comportamento dos dentes metálicos nas seções próximas ao pilar e à viga pré-moldada respectivamente. Estão apresentados os valores médios das medidas realizadas nas duas ligações. 


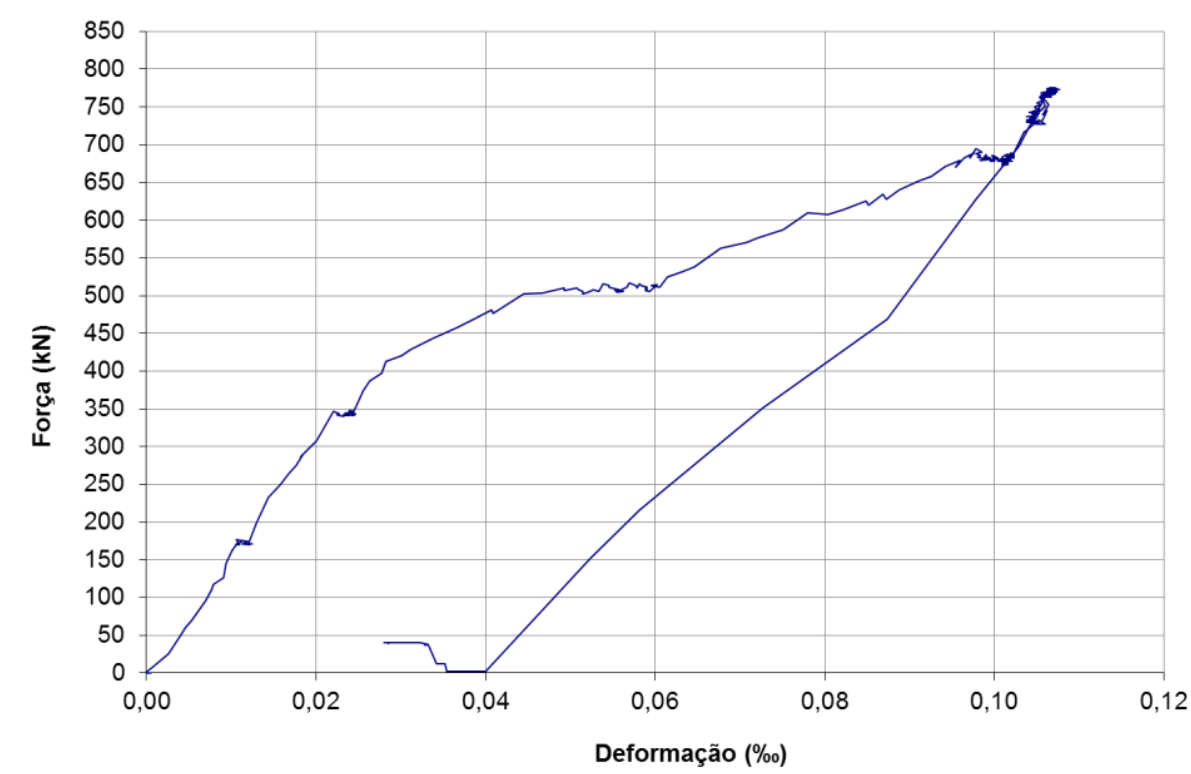

Figura 4.16 - Curva força no pilar-deformação do dente metálico na seção próxima ao pilar média das deformações medidas pelos extensômetros 12 e 24.

Nota-se que no carregamento último a deformação máxima do dente metálico embutido na viga pré-moldada na seção próxima ao pilar foi de apenas $0,10 \%$, devido a não haver ligação soldada entre o dente e o consolo por mesas superiores, apenas pelas almas do perfil "U" do consolo. A solda transmitiu as tensões do consolo para o dente metálico, mas como a resistência à flexão do consolo é muito menor do que a do dente, este não foi muito solicitado e não chegou ao estado limite último.

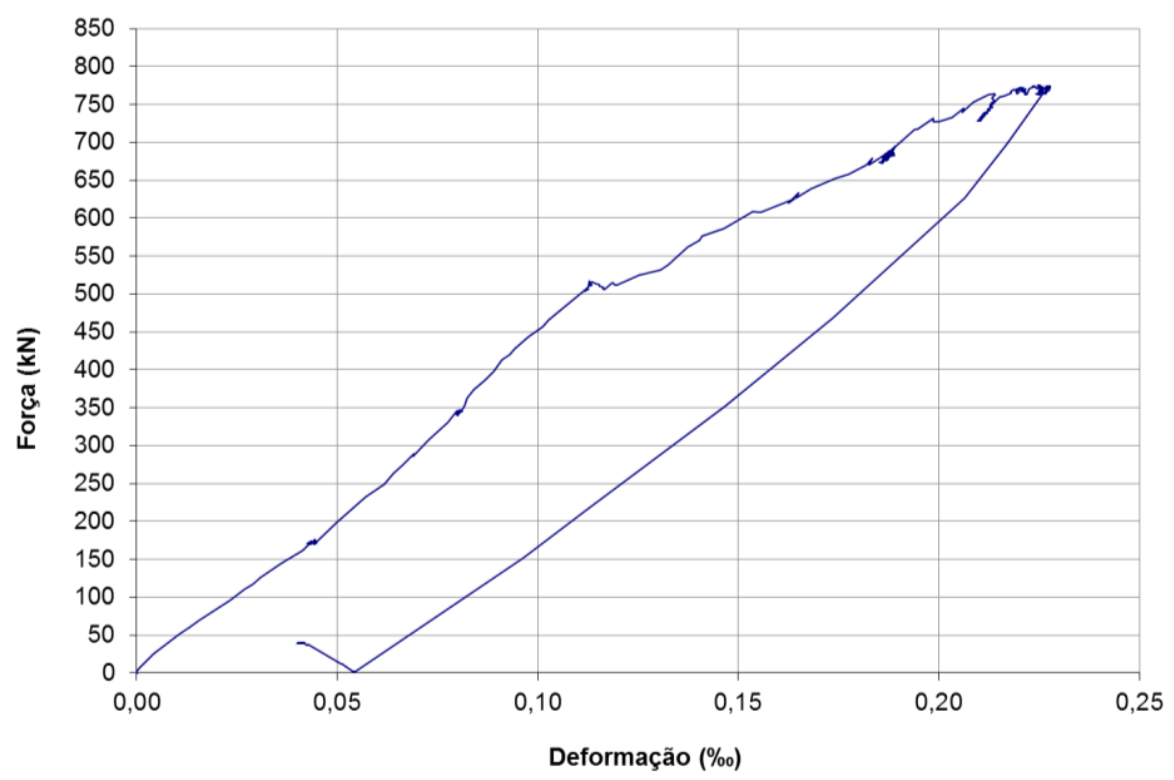

Figura 4.17 - Curva força no pilar-deformação do dente metálico na seção próxima a viga média das deformações medidas pelos extensômetros 11 e 23. 
Nesta seção o dente metálico sofreu uma deformação de 0,23 \% com uma aplicação de momento fletor negativo na seção de $-345,32 \mathrm{kN} . \mathrm{m}$, menor que a deformação do início de escoamento de $1,29 \%$.

A Figura 4.18 apresenta as curvas da deformação das barras da armadura negativa em função da força aplicada abaixo do pilar.

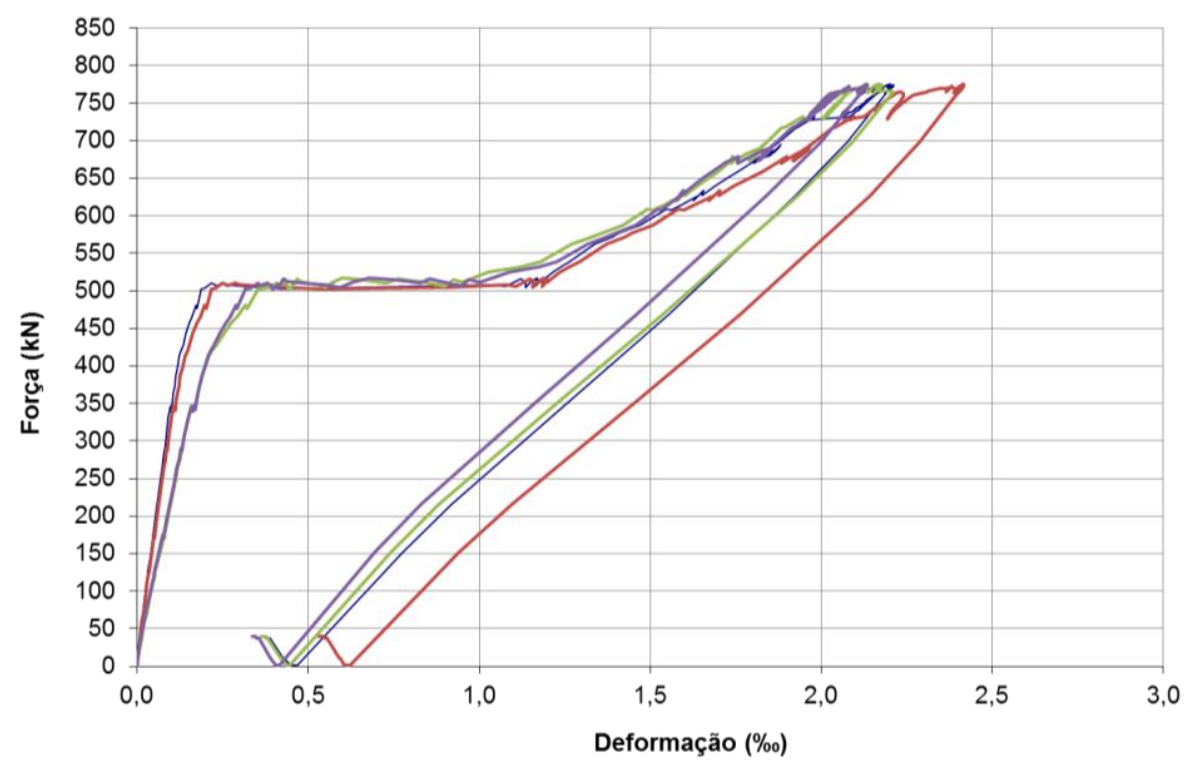

Figura 4.18 - Curva força no pilar-deformação das armaduras negativas das vigas (extensômetros 1, 2, 14 e 15).

Para as armaduras negativas soldadas ao dente metálico a deformação do início do escoamento dada pelo ensaio de caracterização é de 2,84 \%o como já comentado. O momento máximo na seção das barras onde foram fixados os extensômetros, próximo ao dente metálico, foi de $-308,46 \mathrm{kNm}$.

Na Figura 4.19 está apresentado o gráfico da média dos valores de deformação considerando todas as barras da armadura negativa das duas vigas. 


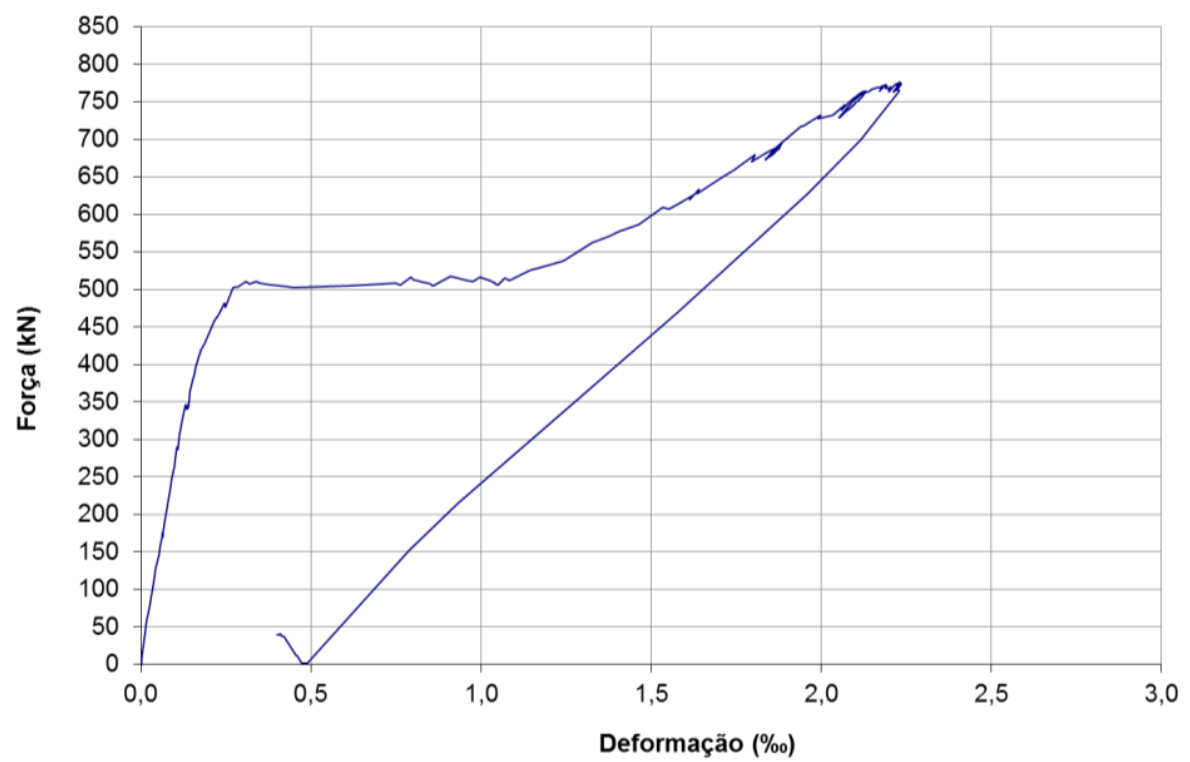

Figura 4.19 - Curva força no pilar-deformação das armaduras negativas das vigas - média dos valores de deformação das duas vigas.

A deformação máxima nas barras da armadura negativa foi de 2,24 \%o, menor que a deformação de início de escoamento de 2,84 \%, portanto não atingiu o estado limite último.

Analisando a fissuração nesta segunda etapa do ensaio, ocorreu uma abertura maior para as fissuras existentes, prolongamento destas e aparecimento de novas fissuras. Próximo ao carregamento último ocorreu fissuras da ordem de $1,50 \mathrm{~mm}$.

Nesta etapa do ensaio houve cisalhamento na interface entre a laje alveolar e a capa apresentado pelo aparecimento de uma fissura contínua nessa região, mostrada na Figura 4.20.
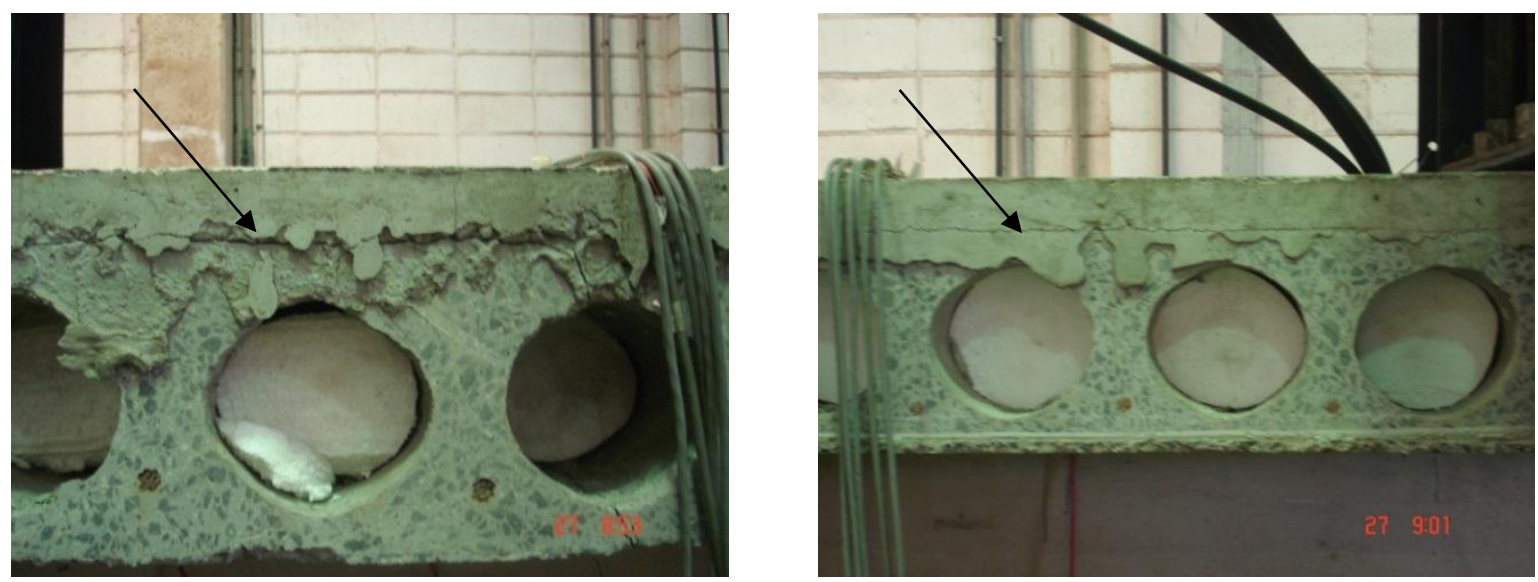

Figura 4.20 - Fissuras devidas ao cisalhamento na interface dos painéis alveolares da laje com a capa de concreto.

A Figura 4.21 mostra a forma de fissuração da capa da laje no final desta etapa. 


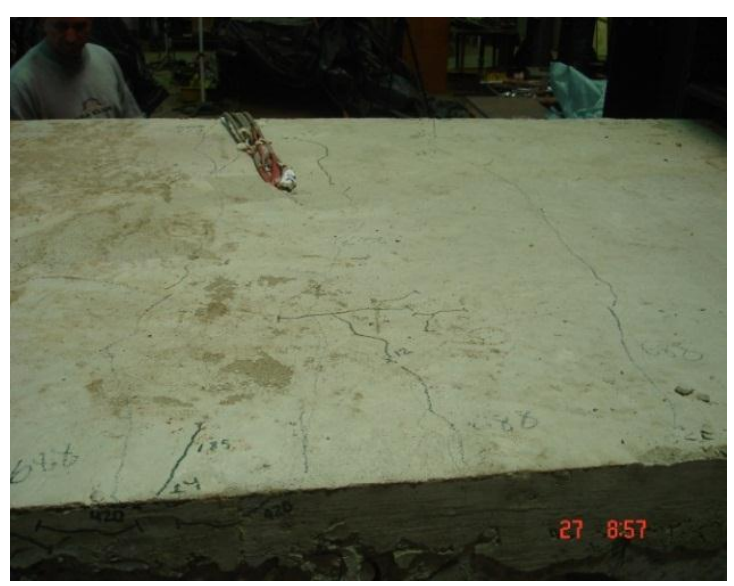

a)

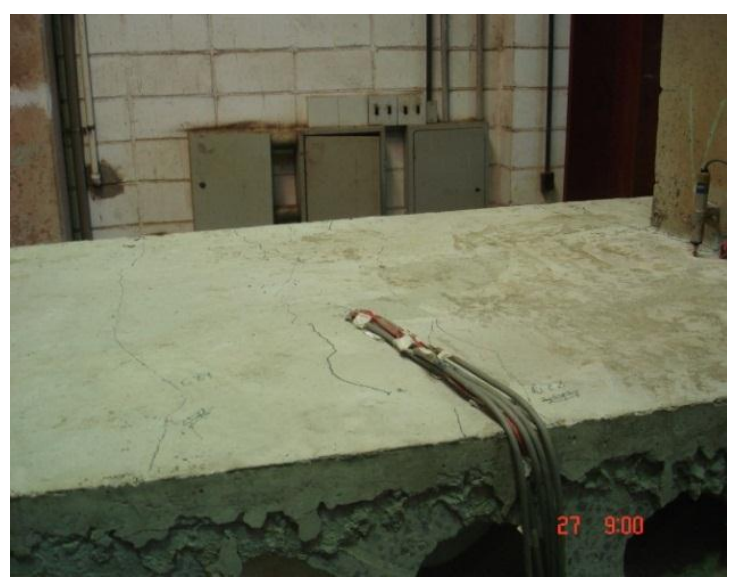

c)

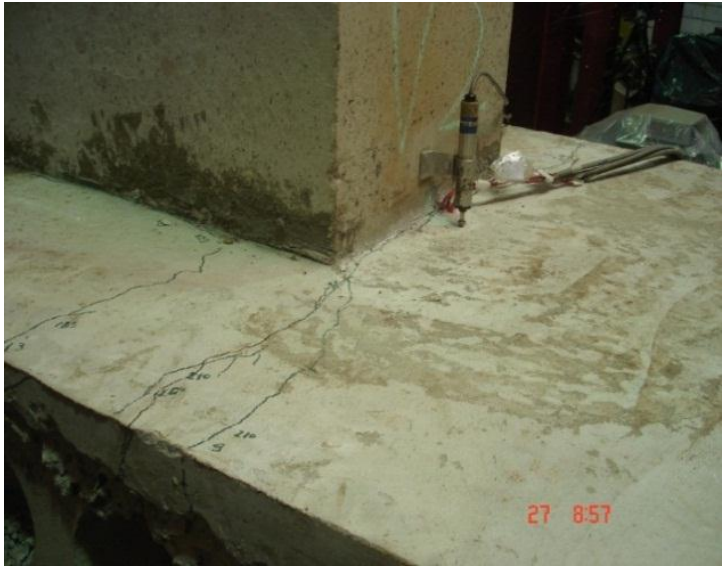

b)

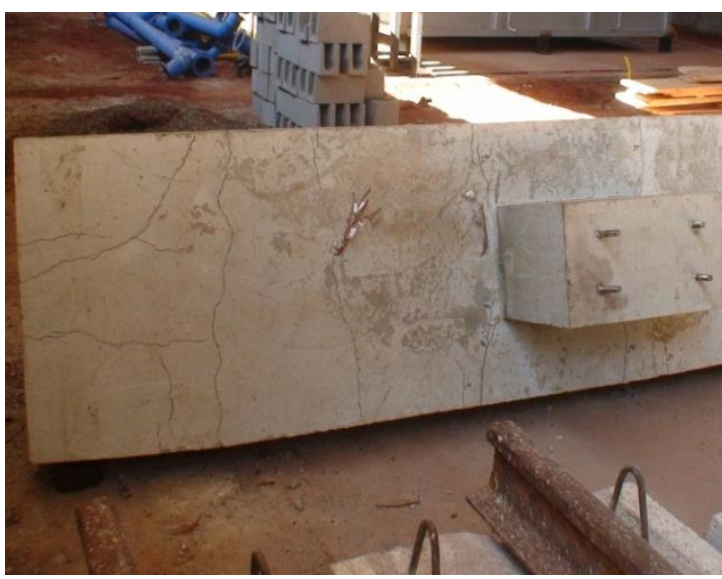

d)

Figura 4.21 - Fissuras devido ao momento negativo na capa da laje.

No início do ensaio ocorreu apenas a abertura das fissuras que surgiram durante a primeira etapa, após ultrapassar a força máxima atingida na primeira etapa formaram-se novas fissuras afastadas da face do pilar próximas a meia distância do pilar ao apoio e junto ao apoio com mudança de direção, como pode ser visto na Figura 4.21 d).

Após o término do ensaio, as fissuras na capa da laje junto ao pilar mantiveram uma abertura de aproximadamente $1,5 \mathrm{~mm}$, mostradas na Figura 4.22 a). As fissuras a meia distância do pilar ao apoio abriram com a aplicação de uma força de aproximadamente 688 kN, próximo do carregamento último, apresentadas na Figura 4.22 b). 


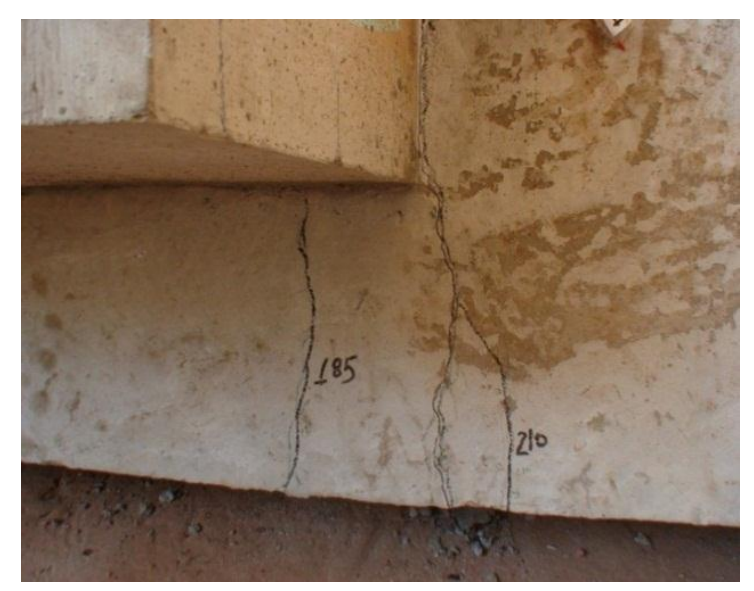

a)

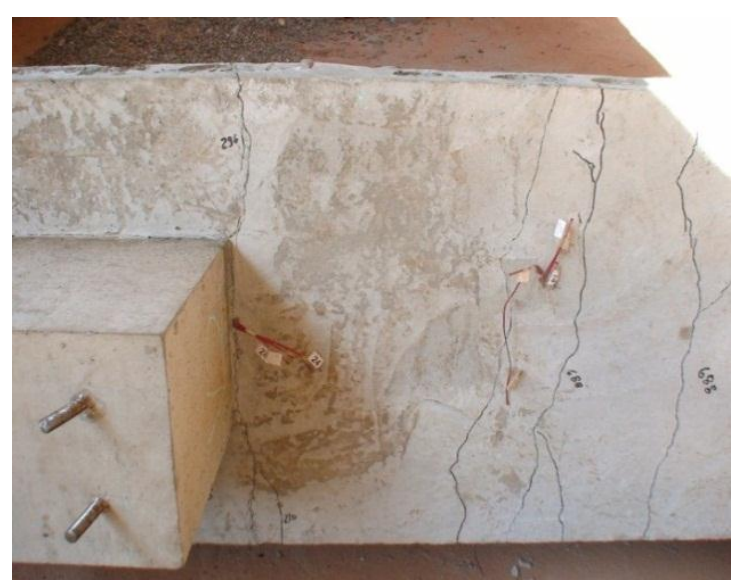

b)

Figura 4.22 - Detalhe das fissuras na capa da laje.

$\mathrm{Na}$ região próxima ao apoio, as fissuras mudaram de direção (Figura 4.23). Isso pode ter ocorrido devido à compressão da laje no apoio. A Figura 4.24 mostra que nos dois apoios ocorreu uma fissura na direção vertical em toda a altura da laje, mas não se propagou pela viga.

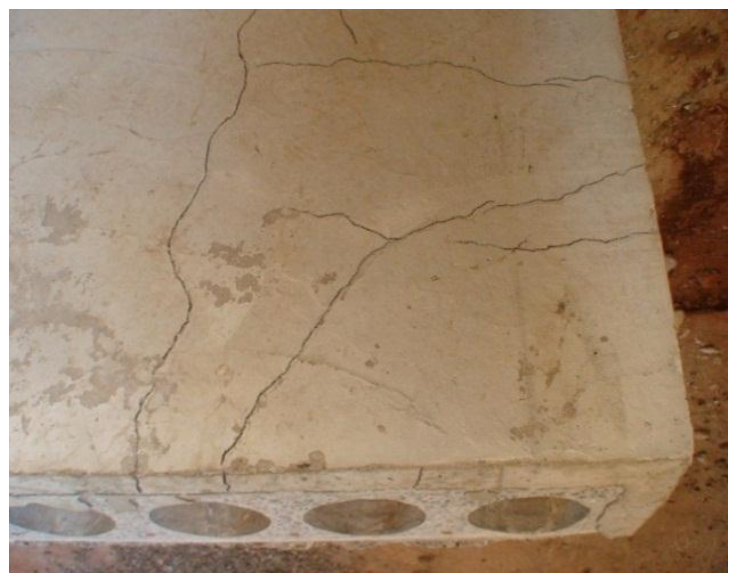

Figura 4.23 - Mudança de direção das fissuras próximas ao apoio. 

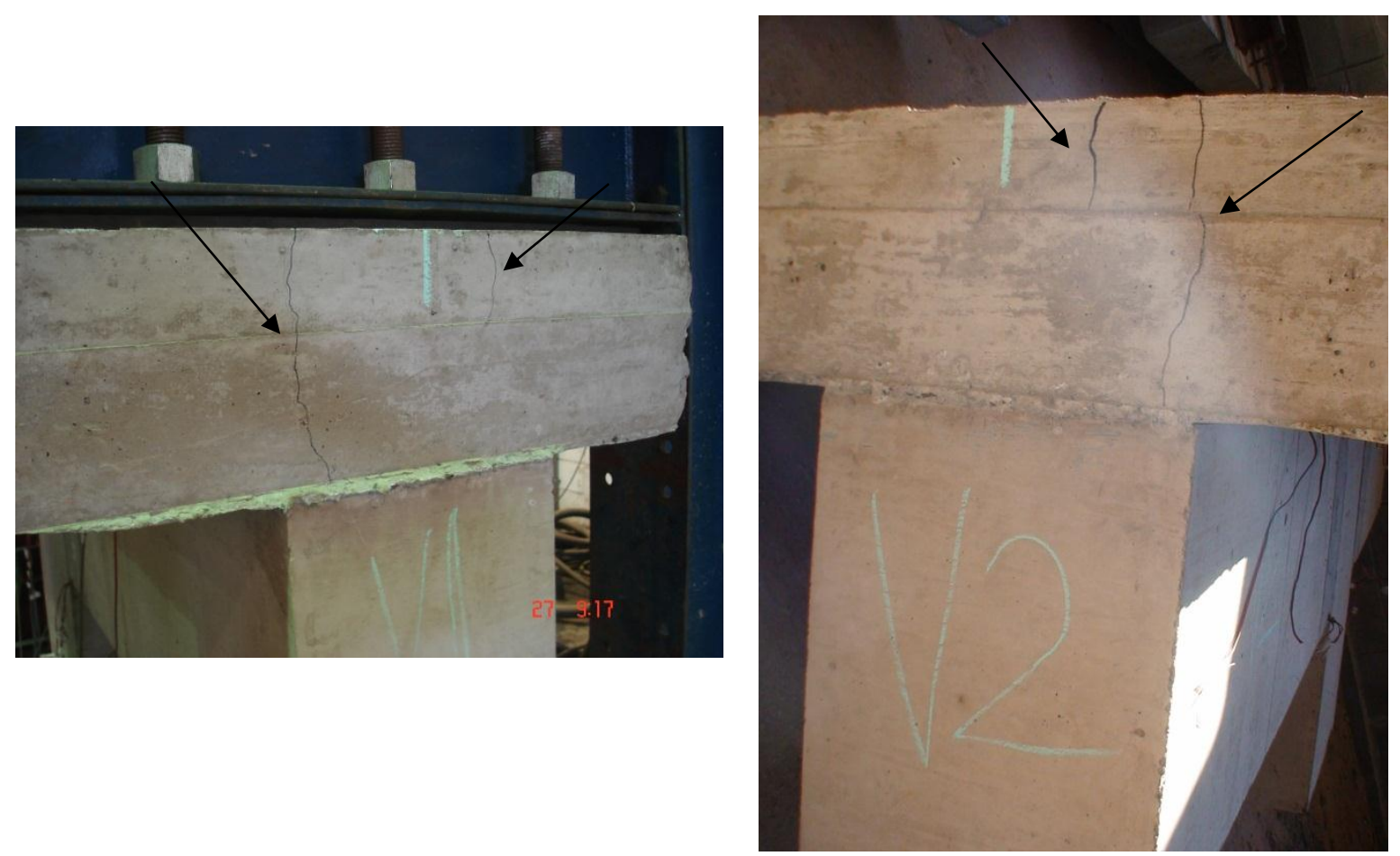

Figura 4.24 - Detalhe das fissuras verticais na laje nos dois apoios.

As fissuras de tração devido ao momento fletor negativo que propagaram pelas vigas ocorreram em três regiões do modelo. A Figura 4.25 mostra uma vista geral do modelo com essas fissura.

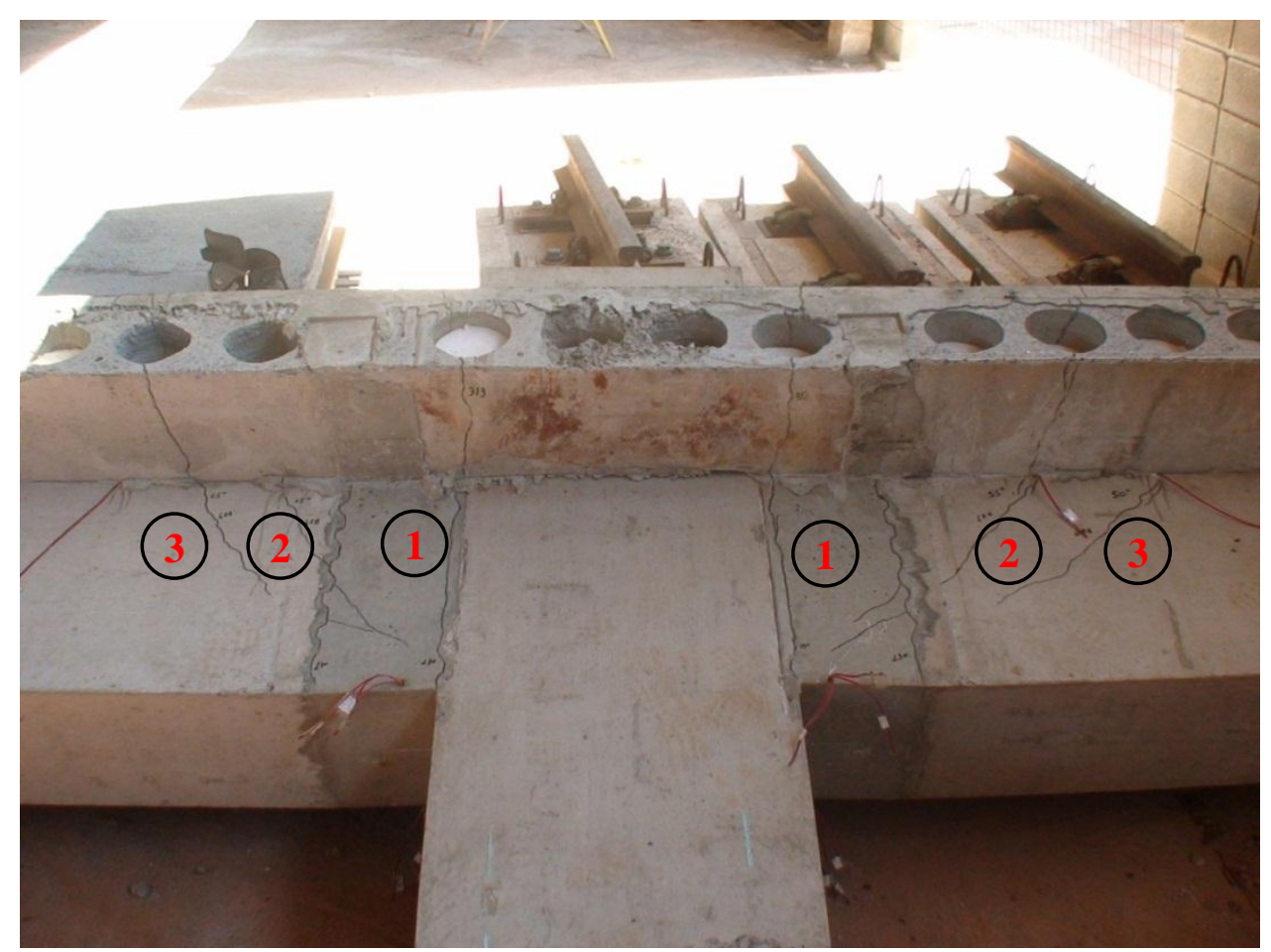

Figura 4.25 - Vista geral da fissuração ocorrida nas vigas do modelo. 
Na Figura 4.25 os números destacados indicam a ordem de aparecimento das fissuras.

A fissura 1, apresentada em detalhe na Figura 4.26 a) abriu na primeira etapa do ensaio, pois o consolo metálico embutido no pilar escoou, conforme comentado anteriormente. Houve a ruptura da laje e a fissura propagou-se pela viga juntando com a fissura aberta na mesma seção transversal devido ao momento positivo.

As fissuras 2 e 3 ocorreram com o carregamento próximo da ruptura com inclinação de $50^{\circ}$ e $55^{\circ}$ em uma viga e de $65^{\circ}$ na outra viga, mostrada na Figura 4.26 b) e c) respectivamente. Essas fissuras são a continuação das fissuras abertas na laje localizadas próximas a meia distância do pilar ao apoio.

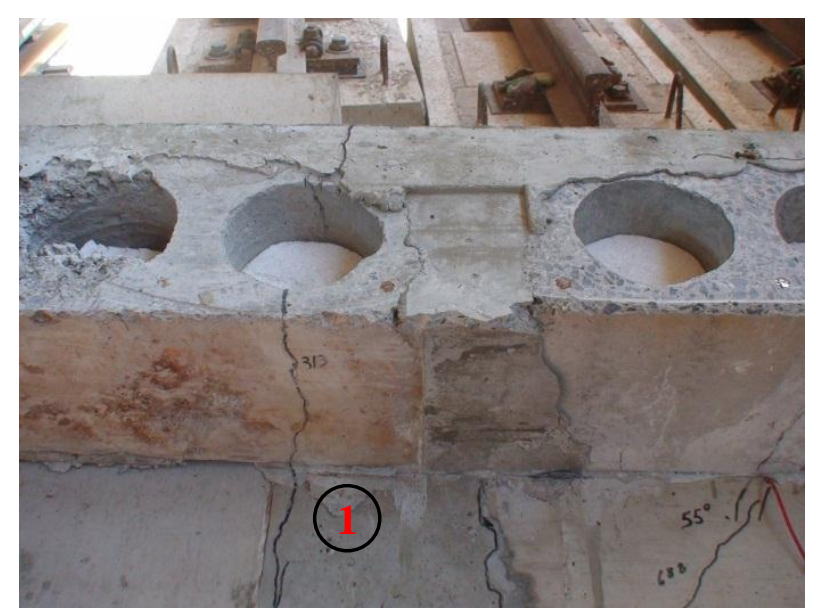

a)

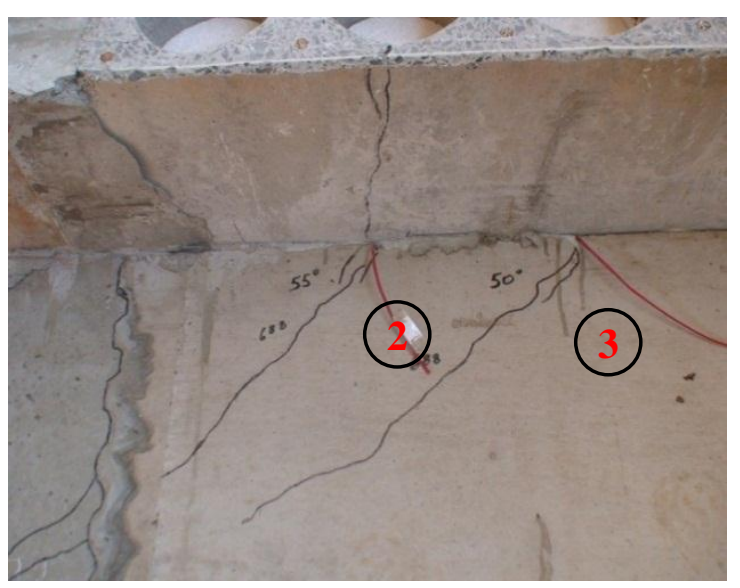

b)

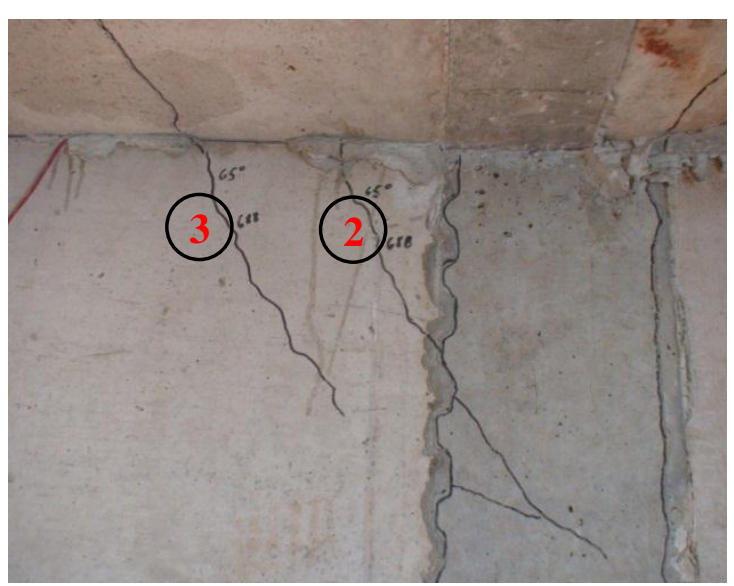

c)

Figura 4.26 - Detalhe da fissuração nas vigas pré-moldadas.

Nota-se que o aparecimento de fissura na ligação ocorreu apenas na seção menos resistente, onde não foi realizada uma ligação soldada entre mesas superiores consolo e do 
dente, e em um trecho de propagação da fissura 2 que se iniciou afastada da região da ligação. Isso é devido à alta taxa de aço existente na ligação e da eficiência da solda entre os perfis metálicos embutidos no pilar e na viga.

\subsection{ANÁLISE DOS MECANISMOS DA LIGAÇÃO}

A seguir será realizada uma verificação da resistência da ligação quanto ao momento fletor podendo comparar os resultados calculados com os experimentais. Será feita a análise dos mecanismos resistentes considerando diferentes seções ao longo da ligação e da viga prémoldada para momento negativo e positivo, devido aos diferentes elementos componentes da estrutura. Não será considerada a armadura da capa da laje como resistente, pois sua contribuição é pequena, foi colocada apenas para evitar grandes aberturas de fissuras.

\subsubsection{Verificação da resistência do consolo metálico ao momento negativo na ligação junto à face do pilar}

Essa verificação será feita conforme modelo de cálculo apresentado na Figura 4.27. Nessa seção não há a ligação soldada com o dente embutido na viga.

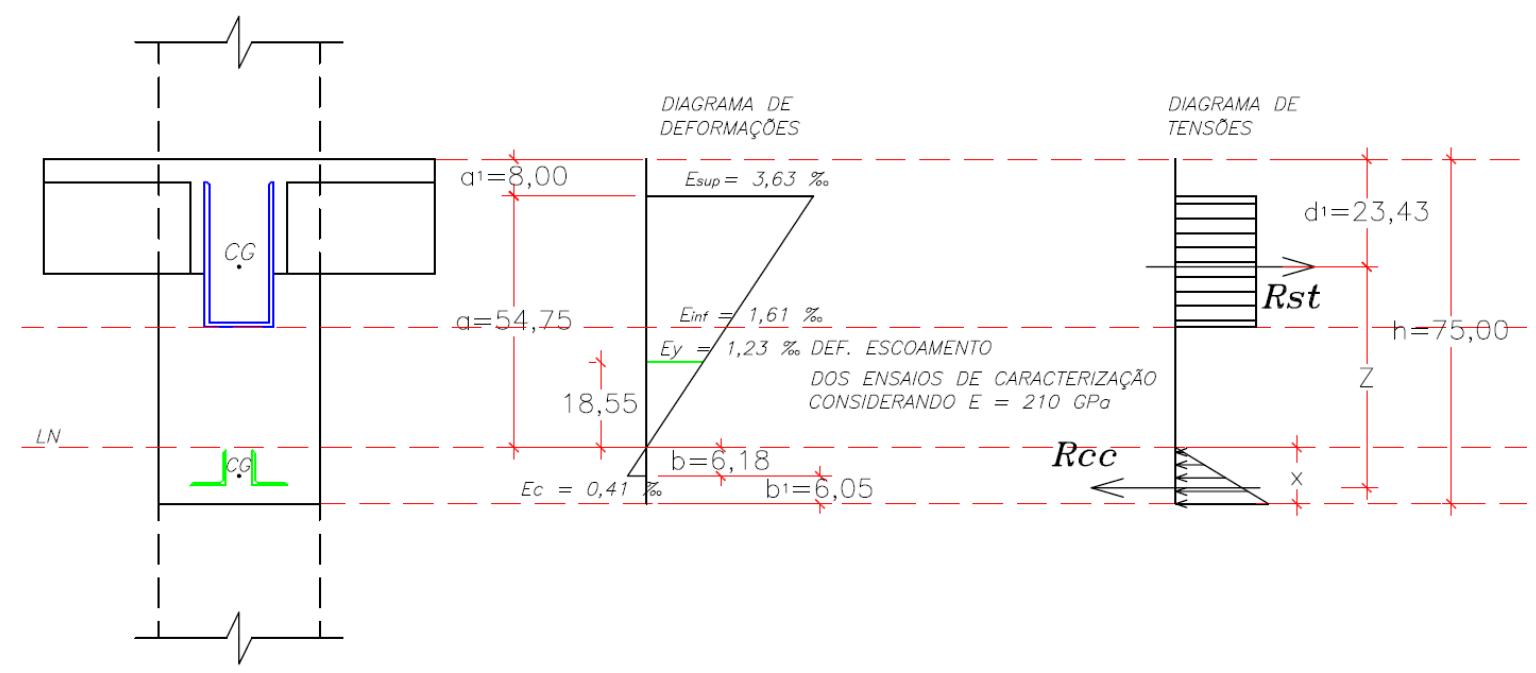

Figura 4.27 - Modelo de cálculo para o consolo.

Da Figura 4.27 verifica-se que todo o consolo metálico está tracionado no instante da ruptura e toda a sua seção está escoando, sendo a deformação na borda superior do consolo 
igual a 3,63 \%o e na borda inferior igual a 1,61\%, ambas maiores que a deformação do início de escoamento de $1,23 \%$.

Com os dados do modelo teórico da Figura 4.27 pode ser calculado o momento fletor do instante da ruptura e comparado com o momento fletor solicitante obtido pelos dados do ensaio.

O momento fletor do modelo teórico pode ser calculado conforme apresentado no quadro a seguir:

$$
\begin{aligned}
& \frac{\varepsilon_{\text {sup }}}{\varepsilon_{c}}=\frac{a}{b} \\
& a+b=h-a_{1}-b_{1}=75,00-8,00-6,05 \\
& a+b=60,95
\end{aligned}
$$

Do sistema acima temos: $\varepsilon_{\text {sup }}=3,63 \%$; $\varepsilon_{c}=0,41 \% ; \boldsymbol{a}=54,75 \mathrm{~cm} ; \boldsymbol{b}=$ $6,18 \mathrm{~cm}$.

$$
\begin{aligned}
& x=b+b_{1}=6,18+6,05 \\
& x=12,23 \mathrm{~cm} \\
& z=h-d_{1}-\frac{x}{3}=75,00-23,43-\frac{12,23}{3} \\
& z=47,49 \mathrm{~cm} \\
& R_{S t}=A_{a} f_{y}=72,10 \times 25,82=1861,62 \mathrm{kN} \\
& M=R_{S t} \cdot z=1861,62 \times 47,49=88408,33 \mathrm{kN} . \mathrm{cm} \\
& M=884,08 \mathrm{kN} . \mathrm{m}
\end{aligned}
$$

Onde,

$\boldsymbol{M}$ é o momento fletor resistente da ligação;

$\boldsymbol{R}_{\boldsymbol{S} \boldsymbol{t}}$ é a força resultante de tração no perfil metálico embutido no pilar;

$\boldsymbol{R}_{c c}$ é a força resultante de compressão no concreto;

$\boldsymbol{f}_{\boldsymbol{y}}$ é a resistência ao escoamento do perfil metálico;

$\boldsymbol{A}_{\boldsymbol{a}}$ é a área da seção transversal do perfil metálico; 
$\boldsymbol{x}$ é a posição da linha neutra;

$\boldsymbol{z}, \boldsymbol{h}, \boldsymbol{d}_{\mathbf{1}}, \boldsymbol{a}, \boldsymbol{b}, \boldsymbol{a}_{\mathbf{1}} \boldsymbol{e} \boldsymbol{b}_{\mathbf{1}}$ conforme Figura 4.27.

Neste caso tomando os valores dos ensaios de caracterização para os parâmetros dos materiais, o momento resistente foi de $884,08 \mathrm{kN}$.m, muito maior que o momento solicitante na ruptura que foi de 523,54 kN.m, apresentado no item 4.3.2. O valor do momento solicitante representa $64,8 \%$ do momento resistente calculado e mesmo assim a ruína ocorreu nessa seção. Observa-se deste fato que o modelo de cálculo pode não ser o mais apropriado para representar o comportamento da ligação na seção analisada.

Como já comentado no item 4.3.1 e Figura 4.5, existe uma falha de concepção da ligação, região que houve o escoamento do consolo metálico. Este problema pode ser resolvido aumentando a área de aço nessa região soldando uma barra de armadura no consolo metálico, na longitudinal, com um traspasse suficiente entre o consolo e o dente da viga, conforme Figura 4.28.

DETALHE DO PILAR NA REGIT̃O DA LIGAÇÃO

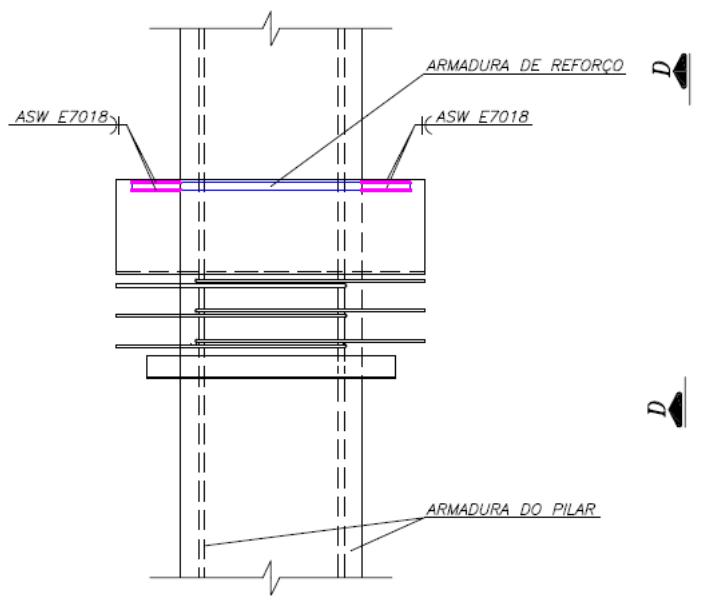

VISTA DO PILAR DD

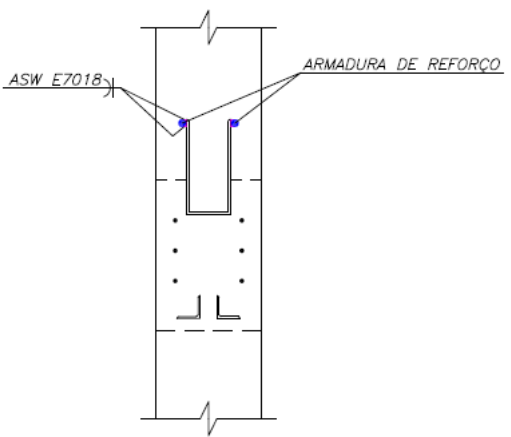

(a) 


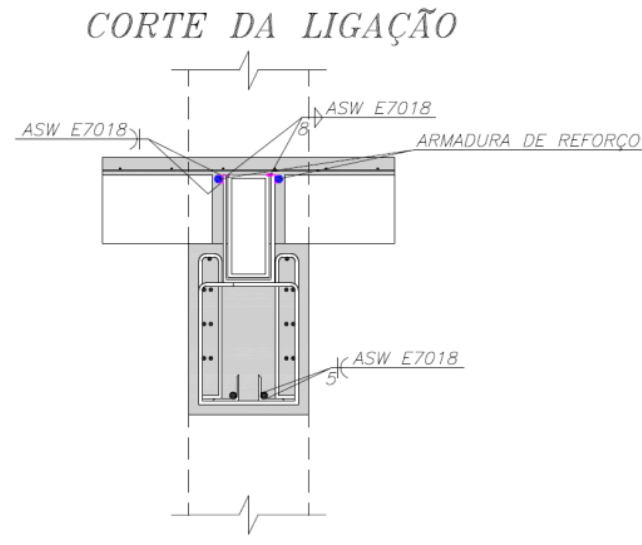

(b)

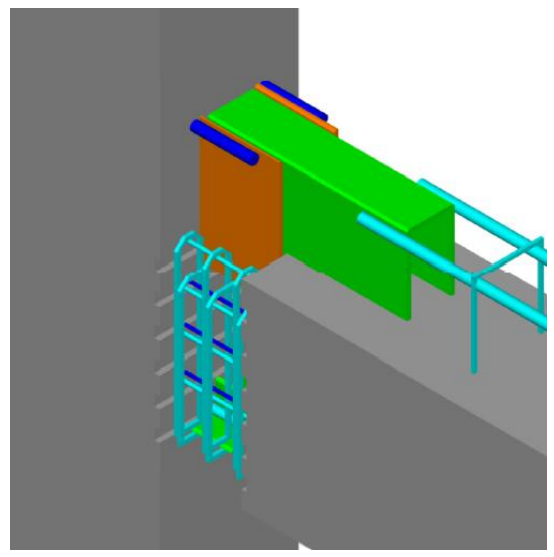

(c)

Figura 4.28 - Detalhe do reforço no consolo metálico: (a) detalhe do reforço no consolo embutido no pilar; (b) detalhe do reforço na ligação; (c) vista 3D da ligação com o reforço. 


\section{CONCLUSÕES}

\subsection{CONCLUSÕES}

Com base nos resultados obtidos neste trabalho, pode-se ressaltar as seguintes conclusões:

A execução do modelo estudado foi relativamente fácil. Não ocorreram contratempos com as formas e armação das vigas e do pilar. Portanto, esse tipo de ligação pode manter uma boa produtividade para a fabricação dos elementos pré-moldados. A maior dificuldade na montagem do modelo é devida às tolerâncias exigidas para soldar os componentes da ligação em campo. Este problema pode gerar perda de produtividade na montagem da estrutura.

A solda da ligação entre os elementos resistentes ao momento negativo pode ser executada com rapidez, devido ao posicionamento favorável. Entretanto, a solda das armaduras positivas nas cantoneiras pode resultar em perda de produtividade da montagem da estrutura, pois a posição do soldador é desfavorável e nessa região a taxa de armadura é alta, sobrando pouco espaço para movimentar o eletrodo.

Quanto ao comportamento da ligação, o consolo metálico escoou muito antes de atingir a capacidade resistente dos outros componentes da ligação. Durante o ensaio cíclico utilizando o atuador servo-hidráulico, o consolo atingiu uma deformação de $120 \%$ da deformação atingida nos ensaios de caracterização para o início do escoamento. Isso ocorreu devido a não existir uma mesa superior no perfil do consolo soldada à mesa dente metálico 
embutido na viga pré-moldada, assim na seção próxima à face do pilar, apenas o consolo metálico resiste à flexão. No dente metálico, na região mais próxima de onde ocorreu o escoamento do consolo, as deformações foram muito baixas.

$\mathrm{Na}$ ligação resistente ao momento positivo, no ensaio cíclico, as cantoneiras embutidas no pilar foram solicitadas até $50 \%$ da resistência ao escoamento e a armadura positiva na ligação chegou a $38 \%$.

A ruptura do modelo ocorreu com a deformação excessiva de 3,63\% do consolo metálico na região onde não foi possível soldar no dente da viga.

$\mathrm{Na}$ verificação analítica, na seção onde houve o escoamento do consolo do pilar, o momento solicitante foi de aproximadamente $64,7 \%$ do momento resistente calculado e ocorreu a ruptura, superestimando a resistência da ligação. Portanto, o modelo de cálculo apresentado com diagrama de deformações linear pode não representar o comportamento real da ligação, ou o durante a execução do ensaio houve alguma falha que gerou resultados distorcidos.

Soldando barras de aço no consolo metálico na longitudinal até certo comprimento, aumenta-se a área de aço resistente na seção crítica, região onde ocorreu a ruptura da ligação.

\subsection{SUGESTÕES PARA PESQUISAS FUTURAS}

O tema desenvolvido neste trabalho é bastante amplo. Podem ser estudadas diversas variações do modelo de ligação proposto que possuam o comportamento de uma ligação rígida e permitam uma execução rápida e fácil. Algumas sugestões para trabalhos futuros são apresentadas abaixo:

a) A realização de uma análise numérica do modelo proposto neste trabalho para comparar com os resultados experimentais e analíticos.

b) Promover estudos experimentais e numéricos da alternativa de ligação proposta no Capítulo 4, com o reforço no consolo metálico;

c) Realizar uma análise voltada para a resistência quanto à força cortante;

d) Acrescentar extensômetros no consolo embutido no pilar. 


\section{REFERÊNCIAS BIBLIOGRÁFICAS}

AMERICAN SOCIETY FOR TESTING AND MATERIALS (2007). ASTM A370. Standard test methods and definitions for mechanical testing of steel products. West Conshohocken, PA, USA.

ASSOSIAÇÃO BRASILEIRA DE NORMAS TÉCNICAS (1984). NBR 8522: Concreto Determinação do módulo de deformação estática e diagrama - Tensão deformação Procedimento. Rio de Janeiro.

ASSOSIAÇÃO BRASILEIRA DE NORMAS TÉCNICAS (1985). NBR 9062: Projeto $e$ Execução de Estruturas de Concreto Pré-Moldado - Procedimento. Rio de Janeiro.

ASSOSIAÇÃO BRASILEIRA DE NORMAS TÉCNICAS (2001). NBR 6118: Projeto de estruturas de concreto - Procedimento. Rio de Janeiro.

ASSOSIAÇÃO BRASILEIRA DE NORMAS TÉCNICAS (2003). Texto base para revisão da NBR 8800: Projeto e execução de estruturas de aço de edifícios. Rio de janeiro.

BALDISSERA, A. (2006). Estudo experimental de uma ligação viga-pilar de concreto prémoldado parcialmente resistente a momento fletor. Dissertação (Mestrado), Escola de Engenharia de São Carlos, Universidade de São Paulo, São Carlos.

BRUGGELING, A.S.G.; HUYGHE, G.F. (1991). Prefabrication with concrete. Rotterdam, A.A. Balkema. 
CHEOK, G.S.; LEW, H.S. (1991). Performance of precast concrete beam-to- column connections subject to cyclic loading. PCI journal precast/prestressed concrete institute, v.36, n. 3, p. 56-67, May-June.

DOLAN, C.W.; STANTON, J.F.; ANDERSON, R.G. (1987). Moment resistant connections and simple connections. PCI journal precast/prestressed concrete institute, v.32, n 2, p 62-74, March-April.

EL DEBS, M.K. (2000). Concreto pré-moldado: Fundamentos e aplicações. 1.ed. São Carlos, EESC-USP, 441p.

EL-GHAZALY, H.A, AL-ZAMEL, H.S; (1991). An innovative detail for precast concrete beam-column moment connections. Canadian Journal of Civil Engineering, V 18, n 4, p 690710.

ERTAS, O.; OZDEN, S.; OZTURAN, T., (2006). Ductil connections in precast concrete moment resisting frames. PCI Journal, v. 51, n.3, p.66-76, May - June.

FÉDÉRATION INTERNACIONALE DU BÉTON, CEB - FIP (2008). Structural connections for precast concrete buildings - Guide for good practice. Bulletin 43, Lausanne.

FERREIRA, M.A. (1993). Estudo de deformabilidade de ligações para análise linear em pórticos planos de elementos pré-moldados de concreto. 166p. Dissertação (Mestrado) Escola de engenharia de São Carlos, Universidade de São Paulo, São Carlos. 1993.

FERREIRA, M.A. (1999). Deformabilidade de ligações viga pilar de concreto prémoldado. 232p. Tese (Doutorado) - Escola de engenharia de São Carlos, Universidade de São Paulo, São Carlos. 1999.

FERREIRA, M.A. (2001). Analytical design procedure for semi-rigid connections in precast concrete structures. INTERNAL RESEARCH REPORT. School of Civil Engineering, University of Nottingham, United Kingdom, 80 p.

GORGUN, H. (1998). Semi-rigid behavior of connections in precast concrete structures. Nottingham. PhD Thesis - University of Nottingham, United Kingdom.

KHALOO, A. R., PARASTESH, H. (2003). Cyclic loading response of simple momentresisting precast concrete beam-column connection. ACI Structural Journal, v.100, n.4, p.440-445, July-August. 
KULKARNI S.A., LI B., YIP W.K. (2008). Finite element analysis of precast hybrid-steel concrete connections under cyclic loading. Journal of Constructional Steel Research v.64, p.190-201.

LEON, R.T. (1998) Developments in the use of partial restraint frames in the United States. In: CONTROL OF THE SEMI-RÍGID BEHAVIOUR OF CIVIL ENGINEERING STRUCTURAL CONNECTIONS, COST C1 INTERNATIONAL CONFERENCE, 1998. Cost C1: Proceedings. Liege, Belgium. p. 95-104.

LOO, Y. C., YAO, B. Z. (1995). Static and repeated load tests on precast concrete beam-tocolumn connections. PCI Journal, v.40, n.2, p.106-115, March-April.

MARCAKIS, K., MITCHELL, D. (1980). Precast concrete connections with embedded steel members. PCI Journal, v.10, n.1, p.88-116, July-August.

OLIVEIRA JÚNIOR, L. A. (2009). Ligação viga-pilar em elementos pré-moldados de concreto solidarizados por concreto reforçado com fibras de aço: análise estática e dinâmica. Projeto de Pesquisa (Doutorado), Escola Engenharia de São Carlos, Universidade de São Paulo, São Carlos.

PRESTRESSED/PRECAST CONCRETE INSTITUTE - PCI (2004). PCI design handbook: precast and prestressed concrete. 6 ed. Chicago.

STONE, W. C., CHEOK, G. S., STANTON, J. F. (1995). Performance of hybrid momentresisting precast beam-column concrete connections subjected to cyclic loading. ACI Structural Journal, v.92, n.2, p.229-249, March-April.

STANTON, J.F., ANDERSON, R.G., DOLAN, C., McClEARLY, D.E., (1986). Moment resistant connections and simple connections. PCI SPECIAL RESEARCH PROJECT n.1/4, PRECAST/PRESTRESSED CONCRETE INSTITUTE. Chicago, 436 p.

VASCONEZ, R. M., NAAMAN, A. E., WIGHT, J. K. (1998). Behaviour of HPFRC connections for precast concrete frames under reversed cyclic loading. PCI Journal v.43, n.6, p.58-71, November-December. 